\title{
POLÍTICAS PÚBLICAS DE EDUCAÇÃO DE JOVENS E ADULTOS: O PROGRAMA INTEGRADO DE QUALIFICAÇÃO DESENVOLVIDO PELO MUNICÍPIO DE SANTO ANDRÉ
}

Dissertação apresentada à Faculdade de Educação da Universidade de São Paulo para obtenção do título de Mestre em Educação.

Área de concentração: Estado, Sociedade e Educação Orientador(a): Prof $^{\mathrm{a}}$. Dr ${ }^{\mathrm{a}}$. Carmen Sylvia Vidigal Moraes 
Autorizo a reprodução e divulgação total ou parcial deste trabalho, por qualquer meio convencional ou eletrônico, para fins de estudo e pesquisa, desde que citada a fonte.

Catalogação na Publicação

Serviço de Biblioteca e Documentação

Faculdade de Educação da Universidade de São Paulo

374(81) Bronzate, Sandra Torquato

B869p Políticas públicas de educação de jovens e adultos : o Programa Integrado de Qualificação desenvolvido pelo município de Santo André / Sandra Torquato Bronzate ; orientação Carmen Sylvia Vidigal Moraes . São Paulo : s.n., 2008.

183 p. : il, tabs.

Dissertação (Mestrado - Programa de Pós-Graduação em Educação. Área de Concentração : Estado, Sociedade e Educação) - - Faculdade de Educação da Universidade de São Paulo.

1. Educação de jovens e adultos - Brasil 2. Ensino profissional e técnico - Brasil 3. Qualificação profissional - Brasil 4. Trabalhadores - Formação profissional - Brasil 5. Políticas públicas - Educação - Brasil I. Moraes, Carmen Sylvia Vidigal, orient. 


\section{FOLHA DE APROVAÇÃO}

\section{Sandra Torquato Bronzate}

Políticas Públicas de Educação de Jovens e Adultos: O Programa Integrado de Qualificação desenvolvido pelo município de Santo André

Dissertação apresentada à Faculdade de Educação da Universidade de São Paulo para obtenção do título de Mestre em Educação.

Área de concentração: Estado, Sociedade e Educação Orientador(a): $\operatorname{Prof}^{\mathrm{a}}$. Dr ${ }^{\mathrm{a}}$. Carmen Sylvia Vidigal Moraes

Aprovado(a) em:

\section{Banca Examinadora}

Prof. Dr. Celso de Rui Beisiegel

Instituição: Faculdade de Educação - USP

Assinatura:

Prof $^{\mathrm{a}}$. Dr ${ }^{\mathrm{a}}$. Marise Nogueira Ramos

Instituição: Universidade Estadual do Rio de Janeiro Assinatura:

Prof. Dr. João dos Reis Silva Junior

Instituição: Universidade Federal de São Carlos

Assinatura:

Prof $^{\mathrm{a}}$. Dr ${ }^{\mathrm{a}}$. Lisete Regina Gomes Arelaro

Instituição: Faculdade de Educação - USP

Assinatura: 
Aos meus pais, que, pelo esforço cotidiano e amor sempre presente, possibilitaram meu caminho até aqui.

Ao tio Hercílio, que, com seu carinho e interesse pelos livros, me ensinou desde muito cedo a ter gosto pelo conhecimento.

À minha irmã, querida e amada companheira de todas as horas.

Ao Rodrigo, alegria de nossas vidas... 


\section{AGRADECIMENTOS}

À Prof ${ }^{\mathrm{a}}$. Carmen Sylvia, que admiro pelo conhecimento e pela pessoa que é, pelo carinho, orientação e atenção dispensadas.

Ao Neto e IIEP, que ajudaram com informações e discussões que contribuíram para melhor compreensão da formação profissional.

Aos que participaram deste trabalho, alunos, professores, e todos que contribuíram para que ele se realizasse.

Aos colegas de trabalho destes anos, que tantas vezes assumiram minhas tarefas, nos momentos em que me dedicava a este estudo.

Aos amigos, pelo incentivo, companheirismo e amor fraterno.

A todos que de alguma maneira passaram pela minha vida, e me ajudaram a construir uma visão da vida e do mundo, que me levou a este trabalho. 


\section{RESUMO}

BRONZATE, S. T. Políticas públicas de Educação de Jovens e Adultos: o Programa Integrado de Qualificação desenvolvido pelo Município de Santo André. 2008. 183 f. Dissertação (Mestrado) - Faculdade de Educação, Universidade de São Paulo, São Paulo, 2008.

Em sua trajetória histórica, a Educação de Jovens e Adultos no Brasil esteve, na maior parte do tempo, relegada ao segundo plano pelas políticas governamentais. A partir da década de 90 do século XX, deslocada das políticas públicas de educação instituídas pelo governo federal do período, foi realizada como política assistencial e instituída, prioritariamente, na forma de campanhas de alfabetização. Definida como atribuição dos Municípios, mas sem destinação orçamentária, passou a ser assumida por eles e financiada com recursos próprios, sem uma orientação nacional. Por sua vez, o ensino profissional, no mesmo período, sofreu alterações profundas em suas propostas pedagógicas e regulamentação institucional. Estabeleceu-se a separação entre o ensino médio e o ensino técnico, além da criação de um sistema de educação profissional hierarquizado em diferentes níveis - básico, técnico e tecnológico -, conferindo à organização da educação brasileira um traço marcadamente dualista. A educação profissional básica, sustentada com recursos públicos, por meio do Plano Nacional de Qualificação/ PLANFOR - MTE, visando atender às novas demandas de qualificação e requalificação do mercado de trabalho, surge como alternativa de "educação" aos trabalhadores que apresentavam baixa escolaridade e qualificação, e, em conformidade com o discurso da empregabilidade, como solução para os problemas de desemprego. Contrapondo-se à orientação federal, é criado, no ano de 2002, na cidade de Santo André, no Estado de São Paulo, um programa que propunha integrar as duas dimensões: a educação escolar básica e a denominada educação profissional básica, através de um feixe de políticas articuladas que viessem a incorporar as reivindicações de setores e organizações populares relativas à formação profissional. Este trabalho analisa o Programa Integrado de Qualificação - PIQ desenvolvido no Município de Santo André, desde sua implantação, em 2003, até o ano de 2006. A pesquisa foi realizada a partir de fontes documentais oficiais, questionários aplicados em alunos, e entrevistas com os demais participantes - os professores, assistentes pedagógicos, coordenadores de entidades conveniadas e diretores do Programa -, com o objetivo de apreender o seu percurso histórico, relacionando as informações oficiais às representações/ interpretações dos diferentes agentes sociais que dele participam. Os resultados indicam que parte das proposições do PIQ não se concretizou, e que os diferentes agentes têm interpretações diversas, por vezes, antagônicas, dos processos que levaram a essa situação. Questões de ordem externa, como as dificuldades existentes, no âmbito legal, de financiamento da Educação de Jovens e Adultos e da qualificação profissional, associadas àquelas encontradas junto aos órgãos que sancionam as contas públicas e têm entendimentos diferenciados do investimento em educação, assim como as questões internas, relativas à gestão do PIQ, levaram à readequação do Programa, comprometendo os seus objetivos iniciais. Apesar dos obstáculos existentes, o Programa Integrado de Qualificação apresenta potencialmente condições para constituir-se em importante alternativa educacional à população trabalhadora, principalmente em um cenário de mudanças das políticas públicas, no âmbito federal, favoráveis às suas orientações, desde que, as dificuldades apontadas neste trabalho, sejam consideradas.

Palavras-chave: Educação de jovens e adultos. Qualificação profissional. Formação inicial e continuada de trabalhadores. Educação profissional. Políticas públicas. 


\begin{abstract}
BRONZATE, S.T Public Policy for Education of Youths and Adults: The Integrated Programme of Qualification developed by Santo André Council 2008. 183 f. Dissertation (Masters) - Faculdade de Educação, Universidade de São Paulo, São Paulo, 2008.

In its historical trajetory, the Education of Youths and Adults has been, most of time, relegated to the background by governmental policy. From the nineties on, in the twentieth century moved from public education policy set up by the Federal Government from that period, it was done as a prioritary assistential and set policy into a literacy campaign form. Definited as an atribution of the council, but without any budget allocation, it became a commitment by them and it was financed with their own resources without any national guidance. In turn, the professional education in the same period, has undergone deep changes in their pedagogical proposals and institutional regulations It was established a separation between the high school education and technical education besides a system of professional education hierarchical in different levels- basic, technical and technological -, giving to the organization of Brazilian Education a markledy dualist mark. The basic professional education, supported by its own resources, through the Integrated Programme of Qualification / PLANFOR (National Plan for Training) - MTE (Ministry of Labour and Employment), aiming to meet the new demand of qualification and requalification in the labour market, has arisen as an alternative of "education" for workers who have shown low schooling and qualification and according to the employability speech, as a solution for the unemployment issues. Opposing to a federal guidance, it was created, in 2002, in Santo André City, in São Paulo State, a program that proposed to integrate both dimensions: the basic school education and the basic professional education, through a cluster of articulated policy taht could incorporate the claims from popular sectors and organizations related to professional graduation. This paper examines the Integrated Programme of Qualification -PIQ, which was developed in Santo André City, since its deployment in 2003, up to 2006. The search was made from official sources documentary, questionnaire applied to sudents, and interviews with others participants - the teachers, pedagogical assistants, coordinators of entities agreements and directors of the Program - aiming to seize its historical journey related to official information to representations/interpretations from several social agents who take part in it. The results show that part of PIQ propositions hasn't been achieved and different agents have several interpretations, sometimes even antagonist about the process that led to this situation. Matters of foreign order such as the difficulties existing in the legal framework, of financing the education of youths and adults and professional qualification, those found associated with the bodies that sanction the public accounts and have different understandings of investment in education as well as internal issues concerning the PIQ management led to the Program adjustment, jeopardazing its initial goals. Besides the existing obstacles, the Integrated Programme of Qualification, presents potentially able to form itself into an important alternative to the working population mainly in a scenery of changing public policy under federal scope to its guidelines provided that the difficulties mentioned in this paper are considered.
\end{abstract}

Key word: Education of Youths and Adults. Professional Qualification. Initial and Continuous Workers Formation. Professional Education. Public Policy. 


\section{LISTA DE TABELAS}

Tabela 1 - Número de Estabelecimentos Industriais na Região do ABC, 1940/1994...........59

Tabela 2 - Número de estabelecimentos industriais na região do ABC...............................59

Tabela 3 - Distribuição dos empregados na região do ABC................................................62

Tabela 4 - Distribuição setorial dos postos de trabalho do Grande ABC - 2001..................64

Tabela 5 - Distribuição setorial dos postos de Santo André - 2001.....................................64

Tabela 6 - Distribuição do pessoal ocupado, segundo a distribuição na ocupação e anos de estudo, em Santo André, em 2000..................................................................66

Tabela 7 - Centro Público de Formação Profissional Júlio de Grammont comércio e serviços .94

Tabela 8 - Centro Público de Formação Profissional Onze de Junho - informática.............94

Tabela 9 - Centro Público de Formação Profissional Tamarutaca - construção civil...........95

Tabela 10 - Número de matriculados no PIQ por ciclo em 2005 .........................................99

Tabela 11 - Número de matriculados no PIQ por ciclo em 2006......................................99

Tabela 12 - Número de matrículas no PIQ de 2003 a 2006.................................................99

Tabela 13 - Inscritos por sexo e faixa etária na área da construção civil em 2003...............101

Tabela 14 - Oferta de itinerário formativo CPFP Armando Mazzo - 2004 a 2006..............104 


\section{SUMÁRIO}

INTRODUÇÃO 10

1. O PROJETO DE PESQUISA 10

2. A ORGANIZAÇÃO DA DISSERTAÇÃO 24

CAPÍTULO 1 - CONTEXTO E IMPLANTAÇÃO DO PROGRAMA INTEGRADO

DE QUALIFICAÇÃO 26

1.1 O PROCESSO HISTÓRICO QUE POSSIBILITA O SURGIMENTO DO PROGRAMA

INTEGRADO DE QUALIFICAÇÃO 26

1.1.1 Breve histórico da educação de jovens e adultos e do ensino profissional 26

1.1.2 O Governo Fernando Henrique Cardoso e a transição para o Governo Luiz Inácio

Lula da Silva 36

1.2 O PROGRAMA INTEGRADO DE QUALIFICAÇÃO NO CONTEXTO ATUAL 57

1.2.1 Santo André e a região do ABC

1.2.2 O Departamento de Educação do Trabalhador e o Ensino Profissionalizante 69

1.2.3 A implantação do Programa Integrado de Qualificação 78

1.2.3.1 Proposta pedagógica $\quad 85$

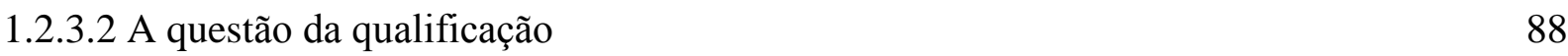

CAPÍTULO 2 - DESENVOLVIMENTO E READEQUAÇÕES DO PROGRAMA INTEGRADO DE QUALIFICAÇÃO 98

2.1 AS DIFICULDADES DA GESTÃO 98

2.2 DESENVOLVIMENTO DA PROPOSTA PEDAGÓGICA 118

2.3 O QUE OS ALUNOS TÊM A DIZER 145

CONSIDERAÇÕES FINAIS

REFERÊNCIAS BIBLIOGRÁFICAS 176 


\section{INTRODUÇÃO}

\section{O PROJETO DE PESQUISA}

Na cidade de Santo André há oferta de educação de jovens e adultos por parte do governo do estado e da prefeitura municipal. O governo do estado trabalha com salas de educação de jovens e adultos de ensino fundamental e médio, ambas oferecidas na forma presencial e à distância. A prefeitura de Santo André oferece, através do Departamento de Educação do Trabalhador, divisão da Secretaria de Educação e Formação Profissional, dentro do campo de educação de jovens e adultos, desde 1989 o Serviço de Educação de Jovens e Adultos - SEJA. Oferece também o Movimento de Alfabetização - MOVA e o Serviço de Educação Profissional que trabalha com formação inicial e continuada de trabalhadores ${ }^{1}$ desde 1997.

O Departamento de Educação do Trabalhador foi instituído em 1997 na segunda gestão do Partido dos Trabalhadores (1997-2000). Assim, na Secretaria, constituíram-se dois departamentos: O Departamento de Educação Infantil (que em 1998 passou a denominar-se Departamento de Educação Infantil e Fundamental) e o Departamento de Educação do Trabalhador. Até então o Serviço de Educação de Jovens e Adultos estava alocado junto à educação infantil, no mesmo departamento, e a formação profissional se configurava enquanto uma ação assistencial (os cursos profissionalizantes encontravam-se vinculados ao Departamento de Promoção Social, na Secretaria de Assistência Social). A partir da criação destes dois departamentos, o SEJA, MOVA e Profissionalizante passaram a constituir os serviços do Departamento de Educação do Trabalhador.

Essa pesquisa terá como objeto um dos programas do Departamento de Educação do Trabalhador: o Programa Integrado de Qualificação, que foi implantado em 2003 e integra elevação de escolaridade na modalidade de educação de jovens e adultos (ensino fundamental e ensino médio) e formação inicial e continuada de trabalhadores, organizada na forma de itinerários formativos ${ }^{2}$.

\footnotetext{
${ }^{1}$ Essa denominação está em vigor desde a publicação do Decreto 5.154 de 23 de julho de 2004 e regulamentada pela Resolução CNE/CEB n ${ }^{\circ}$, de 3 de fevereiro de 2005, Art. $3^{\circ}$, inciso I " Educação Profissional de nível básico" passa a denominar-se "formação inicial e continuada de trabalhadores".

${ }^{2}$ Conforme descrito no Decreto ${ }^{\circ} 5.154$, de 23 de julho de 2004. Art. $3^{\circ}, \S 1^{\circ}$, itinerário formativo é "o conjunto de etapas que compõem a organização da educação profissional em uma determinada área, possibilitando o aproveitamento contínuo e articulado dos estudos". Este conceito será melhor descrito neste trabalho posteriormente.
} 
A educação de jovens e adultos, apesar de dizer respeito a uma grande parte da população brasileira, vem sendo tratada, historicamente, como algo marginal pelas políticas públicas oficiais.

Ao tomar contato com a literatura que trata da história da educação no país, verificamos que a educação de jovens e adultos sempre foi relegada ao segundo plano, que as políticas públicas na área foram muito mais motivadas pelas necessidades econômicas ou políticas de dado momento histórico do que pelo reconhecimento de um direito. No momento histórico atual começa a haver uma reversão desse quadro, o qual, apesar de preconizar o direito à educação, negava financiamento via educação formal para atendimento dessa modalidade. Atualmente, está em vigor o Fundo de Manutenção e Desenvolvimento da Educação Básica e de Valorização dos Profissionais da Educação - FUNDEB, cuja proposta de criação foi aprovada em 6 de dezembro de 2006, através da Emenda Constitucional no 53. O FUNDEB substitui o Fundo de Manutenção e Desenvolvimento da Educação Fundamental e de Valorização do Magistério - FUNDEF. Na vigência do FUNDEF não havia destinação de parte deste recurso à educação de jovens e adultos, o que o FUNDEB vem alterar.

Estudar um programa de educação de jovens e adultos que se insere em uma política pública municipal, que surge em um contexto de dificuldades de implantação e manutenção e que passou e passa por momentos importantes de transição no quadro político nacional e na proposta de políticas públicas para essa modalidade, se faz importante, tanto do ponto de vista histórico, quanto de sua possibilidade de efetividade junto à população. Mais ainda, por se tratar de um governo de continuidade do Partido dos Trabalhadores, que tem em seu ideário a proposta de uma educação inclusiva, comprometida com os interesses dos trabalhadores.

O percurso da análise do Programa Integrado de Qualificação oferecido pelo poder público municipal local em Santo André, que atua com educação formal e não formal, busca oferecer elementos que contribuam na discussão de políticas para esse segmento. É preciso levantar a partir do que e como foi concebido o Programa Integrado de Qualificação, como foi incorporado, na sua gestão, pelos que o implementaram, como a população que usufruiu esse Programa o vê, e que influências causou ou não aos alunos que passaram por ele.

A discussão neste campo aponta para o cuidado necessário de se precisar a concepção de educação profissional, a qual relaciona-se diretamente com determinada noção de trabalho: trabalho em uma concepção utilitária, entendido enquanto formação de mão de obra para o mercado, e trabalho entendido, entre outros tantos aspectos, enquanto possibilidade criadora individual e coletiva do homem. Ao se optar pela segunda concepção, toda proposição de educação que se refere ao trabalho deve necessariamente levar em conta o 
universo do conhecimento produzido pelo homem e a necessidade de disponibilizar desse conhecimento a todos. Nessa perspectiva, falar em educação profissional significa defender uma proposta de formação para uma tarefa específica em que todo ou boa parte do universo que rege as condições do trabalho estejam presentes. É isso que dará a possibilidade de se pensar formas alternativas para o próprio trabalho e para as condições que o regem. Esta discussão está na essência da educação profissional, como colocam Frigotto, Ciavatta e Ramos:

\begin{abstract}
Quando se fala em "educação para o trabalho", "formação para o trabalho", "educação-produção", "trabalho como formador de caráter" ou o "valor pedagógico do trabalho", "princípio do conhecimento", expressões muito em voga, de que trabalho e de que educação e conhecimento estamos falando? Sob que relações sociais se efetivam estas práticas? Trata-se do trabalho enquanto relação social fundamental, manifestação da vida, isto é, atividade do homem na apropriação e transformação do mundo, da realidade em si mesma ou do trabalho como "alienação da vida", trabalho assalariado, mercadoria, força de trabalho? (2005, p.9-10)
\end{abstract}

Entende-se que um projeto de educação de jovens e adultos deve responder a todas essas questões, e que um programa de formação profissional na perspectiva do trabalho apresenta, potencialmente, maiores condições de atender as necessidades dos alunos trabalhadores, uma vez que considera o trabalho em sua dimensão ampla e não apenas as necessidades de mão-de-obra do mercado de trabalho. Há iniciativas anteriores, nessa direção, surgidas do movimento sindical e organizações não governamentais. Como isso ocorre em um programa que integra uma política pública municipal? Como os agentes sociais envolvidos no Programa o concebem? Como os alunos que passaram pelo Programa o vêem?

Essas e outras questões formam o Programa enquanto uma política pública de educação de jovens e adultos que pretende ter uma ação diferenciada dos programas que vinculam a idéia de suplência. Investigar o Programa de ensino a partir das pessoas diretamente envolvidas pode indicar o quanto ele contribui para uma proposição de política pública de caráter mais permanente que atenda as necessidades de alunos trabalhadores. Isso será visto em relação e no contexto das atuais políticas estaduais e federais para jovens e adultos.

Nesse sentido, não há uma única pergunta a ser respondida pela pesquisa, mas a possibilidade de levantar questões que perpassam a relação entre educação e trabalho e que sejam relevantes para o campo das políticas públicas de educação de jovens e adultos na perspectiva de mudança e justiça social. 
O Programa Integrado de Qualificação, na sua concepção, busca resolver um dos problemas da formação inicial e continuada de trabalhadores, denominada anteriormente por educação profissional de nível básico, que é viabilizar a qualificação profissional e elevar o nível de escolaridade da população trabalhadora que o procura. A proposta de cursos de qualificação e re-qualificação estava no conjunto de orientações do PLANFOR $^{3}$, que dividiu a educação profissional em três níveis: básico, técnico e tecnológico. No entanto, essa proposta não considera o problema da baixa escolaridade da população brasileira. Conforme aponta Machado:

No Decreto 2.208/97, disposto pelo Governo visando regulamentar o $§ 2^{\circ}$ do art. 36 e os arts. 39 a 42 da Lei $n^{\circ} 9.394 / 96$ (LDB), no seu art. $3^{\circ}$, além das finalidades de qualificação e requalificação, também foi incluída a de reprofissionalização. Tem-se, aqui, como alvo, todos - a maior parte dos trabalhadores brasileiros - que, por deficiência no seu processo de escolarização, não podem ter acesso aos cursos técnicos de nível médio. (MACHADO, 2002, p.84)

Isso coloca a problemática dos cursos da então chamada educação profissional de nível básico. Ela se torna a alternativa para a maior parte da população, excluída do sistema escolar e também da possibilidade de conhecimento profissional científico. É a tentativa de remediar a ausência de uma política educacional e de emprego para jovens e adultos trabalhadores.

O Programa Integrado de Qualificação, ao conjugar em um mesmo currículo a formação escolar e os cursos organizados sob um itinerário formativo, objetiva possibilitar aos trabalhadores acesso a um universo de conhecimentos que supere a idéia de formação na acepção taylorista/fordista de treino para uma única função na divisão do trabalho. Sua proposta pedagógica tem como objetivo metodológico o desenvolvimento do trabalho interdisciplinar, relacionando os conhecimentos escolares de conteúdo geral aos de natureza técnica e operacional, com o objetivo de complementar e aprofundar o aprendizado técnico.

O Programa está organizado, atualmente, em ciclos de dois anos no PIQ I, primeiro segmento do ensino fundamental; dois anos no PIQ II, segundo segmento do ensino fundamental, e um ano no PIQ III, relativo ao ensino médio. No que se refere ao PIQ III, os alunos têm aulas cinco dias por semana, sendo que a carga horária de 800 horas anuais está dividida, aproximadamente, em 40\%, para a parte profissionalizante, e 60\%, para a parte denominada núcleo comum, composta pelas disciplinas escolares. Quanto ao PIQ II,

\footnotetext{
${ }^{3}$ PLANFOR - Plano Nacional de Qualificação Profissional do Ministério do Trabalho e Emprego, que vigorou de 1996 a 2002.
} 
atualmente, a carga horária está atribuída em $20 \%$ para a parte profissionalizante e $80 \%$ para o núcleo comum em seus dois ciclos. Neste caso, os alunos têm quatro dias por semana aulas do núcleo comum e um dia da profissionalização. No PIQ I a carga horária é a mesma do PIQ II, sendo que a carga horária da qualificação está destinada à inclusão digital.

A parte profissionalizante refere-se, em cada Centro Público, à área de ocupação profissional trabalhada: na unidade de Tecnologia da Informação em Software Livre Valdemar Mattei trabalha-se com informática; na unidade Júlio de Grammont, com comércio e serviços; e, na unidade Armando Mazzo (anteriormente denominada Tamarutaca), trabalhase com construção civil. Cada unidade tem uma entidade da sociedade civil que é conveniada à prefeitura para a realização do trabalho. Na Unidade de Tecnologia, a entidade conveniada é a Escola Sindical São Paulo da CUT; no Centro Júlio de Grammont, o CEEP - Centro de Educação, Estudos e Pesquisas: e, na unidade Armando Mazzo, o CES - Centro de Estudos Sociais e Sindicais $1^{\circ}$ de Maio.

Sua proposta inicial é a geração do emprego social, onde os alunos receberiam uma bolsa no valor de um salário mínimo em troca de vivências que fariam em diferentes setores da administração pública, com o objetivo de conhecer os trabalhos que a prefeitura realiza junto à população e estabelecer uma interlocução com as comunidades. Com base em um estudo realizado pelo Observatório da Educação e Trabalho a respeito da situação de desemprego dos trabalhadores de maior faixa etária que perdiam seus postos de trabalho para jovens entre 18 e 26 anos, de menor remuneração, a proposta objetivava reter fora do mercado de trabalho os jovens dessa faixa etária. O pagamento de uma bolsa, concedida através de um fundo comum das várias secretarias envolvidas no Programa, visava possibilitar a realização, por esses jovens, de quatro horas em estudo e quatro horas em trabalho social, evitando, assim, a precarização de sua força de trabalho.

O Observatório da Educação e do Trabalho, por sua vez, tinha o papel de indicar as demandas de formação profissional advindas do contexto econômico da cidade e da região, bem como o de fazer o acompanhamento da qualidade dos cursos oferecidos e o acompanhamento de egressos.

O ingresso no Programa é feito através de uma seleção que considera basicamente a faixa etária dos 18 aos 26 anos, prioritariamente, e o critério sócio-econômico, onde prevalece a preferência por aqueles que apresentam condições mais precárias de vida. 
Este Programa, bem como os outros do Serviço Profissionalizante, ocorre nas unidades dos Centros Públicos de Formação Profissional. A Secretaria de Educação e Formação Profissional definia da seguinte maneira esses espaços, quando da implantação do serviço de educação profissional:

As Unidades de Formação Profissional de Santo André se interligam na perspectiva de um Centro Público de Formação Profissional virtual. São elementos constituintes de um espaço público, no sentido amplo de "público", de formulação e operacionalização de políticas de qualificação de jovens e adultos, homens e mulheres, para a reinserção/manutenção no mercado de trabalho assalariado, para a obtenção do primeiro emprego ou ainda para a geração de renda de diversas formas (autônomo, pequenos empreendedores, cooperativados).

Sua proposta é qualificar e escolarizar munícipes, tendo como referência nossa política de educação inclusiva articulada matricialmente com as políticas de geração de emprego e renda da cidade, de participação popular e do programa integrado de combate à exclusão. (PREFEITURA DE SANTO ANDRÉ, 2000, p.34-35)

A concepção de Centro Público de Educação Profissional proposta e reivindicada por movimentos populares e sindicais nos inícios dos anos 1990, foi apropriada e reformulada nos documentos governamentais produzidos pelo Ministério do Trabalho e Emprego, em particular no PLANFOR (Plano Nacional de Qualificação do Trabalhador), em 1995, na gestão Fernando Henrique Cardoso. Em 1996, no estado de São Paulo, a Secretaria de Emprego e Relações do Trabalho iniciou uma experiência com o programa "Aprendendo a Aprender", que incorporava três projetos: o "Observatório Permanente de Situações de Emprego e Formação Profissional", "Habilidades Básicas e Específicas" e o "Centro Experimental Público de Formação Profissional”. (MEHEDFF, 2002)

Na cidade de Santo André, a partir de 2000, o Centro Público de Formação Profissional também propunha um Centro Experimental, gerido por um Conselho Gestor tripartite, e em consonância com as orientações do Observatório da Educação e do Trabalho, instituído neste mesmo ano.

Entende-se que a análise de uma proposta de política pública de educação de jovens e adultos em âmbito municipal, que visa trabalhar conjuntamente formação geral e formação para o trabalho, pode oferecer elementos para a discussão de uma política que abarque ensino fundamental e médio e sua relação com o mundo do trabalho. A vinculação entre educação e trabalho está presente neste Programa em praticamente todas as suas ações. A pesquisa pretende apontar como esta relação se construiu ou não, e de que maneira ela se fez. 
A pulverização dos programas de educação de adultos e de formação profissional, assim como a descontinuidade das políticas públicas, implementadas pelos diferentes governos justificam e torna ainda mais relevante a realização de estudos que apreendam as experiências desenvolvidas em âmbito local. Como coloca Soares:

Há, na verdade, a ausência de uma política nacional articulada para a EJA? Como essa política se expressa? Esta é a crítica mais recorrente que se vem fazendo ao governo federal. O que existem são ações fragmentadas e desarticuladas, que surgem, desenvolvem-se e, muitas vezes, extinguem-se, sem que resultem efetivamente em políticas de EJA. [...] Caberia, também, perguntarmos se existe uma política dos estados para a EJA. Não. Existem políticas diversas em vários estados. $\mathrm{O}$ fato de não existir uma política indutora na União, exercendo uma ação convocatória, faz com que os estados respondam, de maneira própria, às demandas existentes para EJA. [...] Existe uma política dos municípios para EJA? Não. Existe uma diversidade de políticas para EJA, em muitos municípios. (2001, p.206-207)

A necessidade da pesquisa sobre essa modalidade de ensino decorre também da grande demanda social existente. O cenário que se apresenta indica uma grande procura pela educação de jovens e adultos, mesmo com todo o investimento realizado na educação regular formal, com a ampliação do acesso e políticas de não retenção de alunos. Segundo o INEP ${ }^{4}$, $41 \%$ dos estudantes que iniciam o ensino fundamental não o concluem. Nessa direção, de acordo com Beisiegel (1999), o analfabetismo da população de 15 anos ou mais regrediu ao longo dos anos 90, decorrente da modernização do país e dos avanços no ensino fundamental de crianças. No entanto, os escassos resultados da permanência e progressão no ensino público geram um contingente numeroso de analfabetos funcionais e formam a clientela em potencial dos cursos de alfabetização, ensino supletivo e outras modalidades de preparação para exames de certificação e conclusão do ensino fundamental.

Não há como tratar da educação de jovens e adultos como algo marginal, como exceção por parte do poder público, uma vez que essa população representa um alto percentual de pessoas que não tem escolaridade. Faz-se necessário pensar políticas públicas para esse segmento que sejam eficazes no que toca ao acesso e à permanência e à qualidade social da educação. Como coloca o Parecer 11/2000 do Conselho Nacional de Educação, pelo relator Carlos Roberto Jamil Cury, não se trata de criar mecanismos para "acelerar quem está com atraso escolar", mas, sim, pensar uma proposta de política pública que dê a esse

\footnotetext{
${ }^{4}$ INEP - Instituto Nacional de Estudos e Pesquisas Educacionais Anísio Teixeira é uma autarquia federal vinculada ao Ministério da Educação (MEC), cuja missão é promover estudos, pesquisas e avaliações sobre o Sistema Educacional Brasileiro com o objetivo de subsidiar a formulação e implementação de políticas públicas para a área educacional. (MEC/ INEP, 2007)
} 
segmento um ethos próprio, que não precarize o conhecimento em função de um tempo menor de permanência na escola, mas, seja portadora de uma proposta curricular e metodológica apropriada a indivíduos que têm percursos de saberes próprios e coletivos, bem como expectativas de inserção ou reinserção no mercado de trabalho. Trata-se de uma modalidade que deve ser alvo de atenção e urgente reparação social. Conforme o Parecer 11/2000, do Conselho Nacional de Educação:

[...] a função reparadora da EJA, no limite, significa não só a entrada no circuito dos direitos civis pela restauração de um direito negado: o direito de uma escola de qualidade, mas também o reconhecimento daquela igualdade ontológica de todo e qualquer ser humano. Desta negação, evidente na história brasileira, resulta uma perda: o acesso a um bem real, social e simbolicamente importante. (BRASIL, 2000, p.7)

No atual quadro social, a análise do que existe enquanto experiência de política pública e a proposição de alternativas que respondam à realidade se fazem urgentemente necessárias.

Como observam Mello e Novais (1998), a globalização acelera um processo em que há uma crescente falta de empregos e a mobilidade social torna-se descendente. Por conseqüência, se acirra a concorrência que, indo para além do sistema econômico expande-se para todas as outras esferas da vida.

Sabe-se que a política de educação não é redentora do desenvolvimento econômico do país, constituindo-se um espaço de direito e de democratização do conhecimento humano por excelência. Nessa perspectiva, é de fundamental importância sua articulação com outras políticas para a conquista de melhores patamares de vida para a população.

$\mathrm{Na}$ situação atual da educação brasileira, de acordo com dados sistematizados pelo INEP em 2001, o que requer atenção é o alto índice de não escolarização da população brasileira. Para além dos que não tiveram acesso na idade própria à escola regular, há os que tendo acesso a ela, não a concluem. Isso gera um acréscimo na massa da população que precisa de educação e não está em equivalência idade/série, ou seja, encontra-se excluída do sistema regular de ensino. A prioridade, até 2006, continuava sendo o ensino fundamental, mas havia um grande número de pessoas que estava excluído do sistema regular e, por isso, da oferta de educação prioritária, no país. Um dos problemas centrais era a não vinculação de verbas do FUNDEF à educação de jovens e adultos. Mesmo, agora, com a aprovação do FUNDEB, haverá um período em que os ajustes de financiamento necessitam ser feitos, o que impede a solução imediata do problema. 
Em termos de oferta de educação, a situação aponta para um problema que não é novo, mas nem por isso está resolvido, e se torna mais preocupante em virtude dos investimentos realizados prioritariamente no ensino fundamental. Faz-se necessária uma política pública permanente de educação de jovens e adultos, que as medidas nessa área deixem de se constituir enquanto ações pontuais, como campanhas ou projetos. Há a expectativa de que a educação fundamental promova, efetivamente, a escolarização da população, mas enquanto isso ainda não se consolida, é necessário tratar a educação de jovens e adultos como modalidade de ensino que merece a mesma atenção.

Havia, no país, em 1999, na população residente de 25 a 34 anos, 5,5\% de pessoas sem nenhum nível de instrução, $15,5 \%$ de analfabetos funcionais (que não completaram o $4^{\circ}$ ano do ensino fundamental) e $31,7 \%$ que não completaram o ensino fundamental (que pararam entre $5^{\mathrm{a}}$ e $8^{\mathrm{a}}$ séries). (INEP, 2001, p.26)

No estado de São Paulo, os dados apontam, para a mesma faixa etária 2,1\% de analfabetos absolutos; 9,9\% de analfabetos funcionais; $29,3 \%$ que não concluíram o ensino fundamental. (INEP, 2001, p.26)

Informações levantadas pela Fundação SEADE (2008) indicam que na cidade de Santo André, no ano de 2000, entre a população com 25 anos ou mais, a taxa dos que não concluíram oito anos de escolaridade é de 47,96\%. Com relação ao ensino médio, na população de 18 a 24 anos, os que concluíram este nível de ensino, no ano de 2000, perfazem um total de $51,63 \%$.

Os dados mostram que essa situação merece atenção imediata. É necessário resgatar a educação de jovens e adultos, entendida enquanto modalidade da educação básica, como direito social, cujo cumprimento necessita outra qualidade social, outra qualidade de ação política por parte do poder público. Não se trata de focalizar as atenções só para a questão do analfabetismo. A não escolarização da população é um problema muito maior. Envolve toda essa população e suas relações com o universo do conhecimento humano, do mundo do trabalho, com o conjunto da vida social.

Algumas iniciativas, com o objetivo de trabalhar conjuntamente a formação geral e a formação para o trabalho em educação de jovens e adultos, desenvolvidas por organizações sindicais e ONG's, merecem ser observadas com atenção. Podem ser citados, como exemplos, o Programa Construindo o Saber (CEEP/ Sindicatos diversos/ FE-USP), Projeto de Educação de Trabalhadores (Escola Sindical 7 de Outubro/ Prefeitura de Belo Horizonte), Programa Integrar (CNM/ CUT) e o Programa Vento Norte (Escola Sindical Amazônia/ Escola Sindical Chico Mendes). 
O Programa Integrado de Qualificação é uma iniciativa do poder público municipal, uma política estatal que trabalha, também, com diferentes parcerias (Escola Sindical São Paulo, Centro de Educação, Estudos e Pesquisas - CEEP, Centro de Estudos Sociais e Sindicais $1^{\mathrm{o}}$ de Maio - CES). O diferencial consiste no fato de este Programa desenvolver-se dentro da estrutura da Secretaria de Educação Municipal, constituindo uma política pública do município, o que contrariava, na época de sua implantação, as orientações do governo federal para a educação profissional, o qual, por meio do Decreto $2.208 / 97^{5}$, separava a educação geral da educação profissional.

Para efeito da delimitação teórica e do objeto de pesquisa, é importante colocar que a educação de adultos está circunscrita a dois campos principais: a educação realizada via movimentos e entidades da sociedade civil e a educação desenvolvida por cursos e programas no âmbito das políticas públicas estatais, mantidos pelo poder público. Esta discussão é pertinente, uma vez que há uma tendência, na época, de o Estado chamado neoliberal delegar a responsabilidade de uma política universal e investir nas chamadas políticas focalizadas, direcionando o financiamento a setores que julgassem prioritários, seguindo as orientações dos mecanismos mundiais de financiamento da economia. É nesse contexto que, desde 1990, como aponta Beisiegel,

[...] encontra-se em andamento um processo de transferência das atribuições da educação supletiva, que estão sendo deslocadas para os Estados e, principalmente, para os Municípios. Mas, o número de Municípios realmente empenhados em ações concretas na educação de jovens e adultos é, ainda, muito reduzido. Assim, enquanto a transferência de competências não se concretiza efetivamente, o envolvimento dos poderes públicos com a educação básica de jovens e adultos analfabetos apresenta-se bem menor do que já foi no passado, nas décadas de 1940 a 1980. (1997a, p.241-242)

Além disso, com a delegação de atribuições realizada pelo Estado, é preciso colocar com cuidado a questão dos movimentos sociais e, mais especificamente, dos movimentos ligados à educação popular, analisar, nos diferentes momentos do período estudado, até que ponto estes movimentos estão inseridos na lógica de desobrigação do Estado de suas funções diretas ou se são movimentos que se colocam em uma perspectiva de mudança social, e que vêem nessa atuação junto ao Estado a possibilidade de se estabelecer uma relação mais

\footnotetext{
${ }^{5}$ O decreto 2.208/97 dividiu a educação profissional em três níveis: básico, técnico e tecnológico e em seu artigo $5^{\circ}$ coloca: a educação profissional de nível técnico terá organização curricular própria e independente do ensino médio, podendo ser oferecida de forma concomitante ou seqüencial a este.
} 
democrática e participativa sendo co-participantes de uma política pública partilhada pela sociedade civil e poder público. Nogueira coloca essa preocupação ao afirmar que:

\begin{abstract}
Há uma espécie de tendência objetiva que força a que a participação deixe de ser pensada como recurso vital para a recriação do social, a fundação de novos Estados ou a instituição de formas mais democráticas e civilizadas de convivência, e passe a ser pensada como um meio para a inversão de prioridades governamentais e a transferência de custos gerenciais. [...] Algumas vezes, chega a ser concebida como uma atividade que, no limite, "substituiria" o Estado na implementação de determinadas políticas públicas. O modo como são hoje pensadas e assimiladas as "organizações nãogovernamentais", ou ainda a idéia do "público não-estatal", indicam com clareza essa inflexão. (2004, p.140-141)
\end{abstract}

O objetivo da pesquisa, levando em conta a complexidade que envolve a questão dos movimentos sociais hoje, o que não é objeto direto deste trabalho, consiste em realizar um estudo de caso, isto é, de um Programa realizado por iniciativa do poder público, o poder público municipal. Nesta direção, tem, como uma de suas preocupações, analisar a delegação, aos municípios, de ações políticas antes vinculadas à União ${ }^{6}$. Nesse sentido, as ações do Estado no campo da educação de jovens e adultos e da formação/qualificação profissional, em âmbito federal, estadual e municipal, são temas priorizados neste trabalho.

Uma outra dimensão de pesquisa diz respeito à relação educação e trabalho. Essa é uma relação implícita quando se trata do campo da educação profissional. O importante é apreender como se dá essa relação na dinâmica do programa. É preciso salientar que o entendimento de trabalho não se restringe, aqui, apenas ao aprendizado de técnicas. $\mathrm{O}$ aprendizado técnico é necessário, mas mesmo esse aprendizado, em uma perspectiva que busque a emancipação humana, tem que estar pautado por uma lógica diferente da que defende apenas o treino para uma tarefa específica. Nesse sentido, o que merece destaque, é a necessidade de qualificar o trabalhador na perspectiva da apropriação da ciência e da técnica contida na ação do trabalho. Por isso, mesmo em relação ao ensino das técnicas (que podem assumir um caráter exclusivamente operacional), é preciso ter uma perspectiva de romper com a lógica do domínio do conhecimento somente por parte de alguns. Tanto quanto possível, é preciso democratizar o saber, porque a apropriação do conhecimento pelo trabalhador possibilita a ele maior domínio do seu processo de trabalho.

\footnotetext{
${ }^{6}$ A esse respeito, consultar BEISIEGEL, 1997.
} 
Há uma outra dimensão de trabalho quando o pensamos, na perspectiva de Marx (1989) em termos de atividade humana criadora de valores de uso, de utilidades. Essa outra dimensão criadora do trabalho pressupõe uma concepção ampla de educação, a ser contemplada por uma proposta de ensino/ aprendizagem que contribua para a superação de um modo de produção calcado na exploração humana. Como afirma Arroyo:

O trabalho como princípio educativo situa-se em um campo de preocupações com os vínculos entre vida produtiva e cultura, com o humanismo, com a constituição histórica do ser humano, de sua formação intelectual e moral, sua autonomia e liberdade individual e coletiva, sua emancipação. Situa-se no campo de preocupações com a universalidade dos sujeitos humanos, com a base material (a técnica, a produção, o trabalho), de toda atividade intelectual e moral, de todo processo humanizador.

Penso que estas relações não os vínculos entre trabalho-educação apenas, nem fundamentalmente, às políticas de ensino médio e profissionalizante, nem aos complexos mecanismos de aprendizagem dos saberes, valores e atitudes do trabalhador. Nos remetem em cheio ao projeto de humanização, de educação básica universal da modernidade, do pensamento humanista e socialista. (1998, p.152-153)

Entender o trabalho como princípio educativo, base do projeto educacional, supõe uma série de compromissos políticos e pedagógicos. O primeiro deles é o respeito aos direitos civis conquistados pela humanidade. Dois direitos essenciais, sem mencionar todos os outros direitos humanos, são o acesso ao conhecimento através da educação, e o direito ao trabalho digno. Esses direitos se expressam, ou não, em ações advindas do poder público e das instâncias que governam a sociedade. Cabe à sociedade fazê-los valer, e, um projeto educacional que tem esses compromissos, deve traduzi-los em ações intencionais e cotidianas, pensadas em uma perspectiva de superação da realidade existente. Este é o desafio que se coloca.

Em linhas gerais, o objetivo deste trabalho é apreender como foi concebido o Programa Integrado de Qualificação da Prefeitura de Santo André, quais eram seus pressupostos e finalidades, como foi interpretado e executado pelas pessoas envolvidas, e qual o possível alcance junto à população que o usufruiu.

No que se refere à metodologia utilizada na pesquisa, é preciso situar, em primeiro lugar, o pesquisador e o objeto de estudo. Como observa Abramo:

Nas ciências humanas em geral, e na Sociologia, em particular, a característica metodológica fundamental é dada pelo fato de que sujeito e objeto do conhecimento se confundem, o que traz vantagens e desvantagens para o pesquisador. $(1979$, p.25) 
Isso nos remete à reflexão de que não há possibilidade de neutralidade nas pesquisas em ciências sociais, uma vez que sujeito e objeto estão inseridos em um contexto de relações sociais que condicionem a elaboração de interpretações e representações, pelos sujeitos, acerca desse contexto. É importante colocar esta questão, pois, a escolha do objeto, da metodologia e do referencial teórico tem estreita relação com a forma como o sujeito se vê no conjunto das relações sociais e como ele vê seu objeto. O pesquisador parte de pressupostos teóricos que o levam a formular uma hipótese, pautada em sua perspectiva de homem e de sociedade.

Nesse sentido, a pesquisa apresenta a configuração de um estudo de caso, em que são considerados, para efeito de se tentar desenhar o programa que retrata uma política pública estatal, enquanto política pública municipal, as interpretações e representações dos diferentes agentes sociais envolvidos.

Primeiramente, através de revisão bibliográfica, se fez um esforço em contextualizar e problematizar teoricamente o conjunto de relações que envolvem o objeto. Serão necessários alguns recortes da realidade, uma vez que todo o conjunto de relações que se colocam no campo da educação e do trabalho constituem um universo extremamente amplo que não apresentaria possibilidade concreta de apreensão neste trabalho.

Com relação ao delineamento do Programa Integrado de Qualificação, a pesquisa foi realizada através do levantamento de fontes primárias, oficiais e não oficiais (leis, decretos, documentos elaborados pela Secretaria de Educação, dados obtidos junto ao Observatório da Educação e do Trabalho, planos, projetos, entrevistas e questionário aplicado aos alunos), com o objetivo de traçar tanto o desenho oficial colocado pela Secretaria de Educação e Formação Profissional como o que consideram professores, alunos e outros envolvidos, no registro de suas atividades cotidianas.

No Observatório da Educação e do Trabalho foram levantados dados quantitativos do Programa como o número de atendidos, evadidos, promovidos, não promovidos, certificados e outros que se fizeram necessários para se compor um quadro do atendimento realizado.

Foram feitas entrevistas com os diferentes agentes do Programa. As entrevistas estão delimitadas ao universo de três unidades do Centro Público de Formação Profissional: a unidade de Tecnologia de Informação em Software Livre Valdemar Mattei; a unidade Júlio de Grammont e a unidade Armando Mazzo. 
No que se refere às entrevistas, concorda-se com Thiollent quando observa que:

[...] mais do que a precisão de qualquer tipo de medição, o que importa é a pertinência das questões e das respostas formuladas na interação entre os dois pólos. Por parte do pólo investigador, a "observação" é essencialmente um questionamento. (1987, p.23)

Nessa direção, as entrevistas buscam apreender em cada uma das instâncias, o lugar do entrevistado no Programa, como ele o compreendeu e interpretou, e quais os desdobramentos que essa interpretação trouxe para si e sua ação. Por esta razão, foram entrevistados os professores que atuam no programa; os assistentes pedagógicos que fazem a orientação do trabalho dos professores; as diretoras dos Centros Públicos, que são as pessoas responsáveis pela mediação entre as orientações do Departamento de Educação do Trabalhador e as equipes e alunos dos Centros; os coordenadores das entidades conveniadas que partilham a direção dos Centros junto às diretoras; o diretor do Departamento de Educação do Trabalhador; o assistente de direção do Departamento; bem como o coordenador do Observatório da Educação e do Trabalho. As entrevistas são semi estruturadas.

Com os professores, as entrevistas foram por amostragem intencional, definindo-se que fossem representados nas entrevistas professores das três unidades, sendo dois por unidade, um da base comum e um da área técnica. No caso das diretoras dos Centros Públicos, todas foram entrevistadas, bem como os coordenadores dos convênios, e um assistente pedagógico de cada um dos Centros Públicos estudados. Com relação à equipe diretiva composta por assistência de direção, direção do Departamento de Educação do Trabalhador e coordenador do Observatório da Educação e do Trabalho, as entrevistas também são semi estruturadas.

Com relação aos alunos usuários do Programa, foi aplicado um questionário, no sentido de poder abarcar um número maior de pesquisados e assim possibilitar o surgimento de um maior número de elementos que tanto caracterizassem o perfil da população usuária dos Centros, bem como as idéias, os conceitos, as representações e expectativas que esses alunos são portadores. As questões tinham como preocupação, além do levantamento de dados, proporcionar, de alguma forma, a reflexão dos alunos sobre suas trajetórias de trabalho até aqui, suas expectativas e idéias referentes à relação entre educação e trabalho. 
A escolha das turmas teve como critério que freqüentassem o período noturno e que, em cada Centro, participassem uma turma de PIQ II (ensino fundamental) e uma de PIQ III (ensino médio). A escolha desses ciclos, e não do PIQ I, deu-se em virtude de o PIQ I atualmente não trabalhar especificamente com a qualificação profissional, mas com a inclusão digital. As diretoras ou os assistentes pedagógicos das unidades orientaram sobre em quais turmas proceder à aplicação do questionário. Essas turmas deveriam compor um universo com certas características próprias, como é o caso, por exemplo, da "construção civil", que é formada por quase cem por cento de homens, e a "estética", que é um universo essencialmente feminino.

A escolha pelo período noturno enquanto amostra ocorreu por ele abarcar um número maior de pessoas já participantes do mercado de trabalho, bem como atender a uma maior diversidade de faixa etária. As turmas da manhã e tarde (quando são oferecidas) têm uma predominância tanto de mulheres, quanto de adolescentes, caracterizados principalmente por não estarem inseridos no mercado de trabalho, o que não forneceria uma amostragem interessante do ponto de vista daqueles que compõem a maior parte dos usuários do Programa, visto que o maior número de alunos se concentra no período noturno.

Este questionário foi aplicado entre os meses de novembro e dezembro de 2006.

\section{A ORGANIZAÇÃO DA DISSERTAÇÃO}

A dissertação está estruturada em uma Introdução, que apresenta o projeto de pesquisa bem como a própria organização da dissertação, seguida de dois capítulos que formam o corpo maior do trabalho, e das Considerações Finais.

O primeiro capítulo analisa o contexto em que surge o PIQ, com o objetivo de apreender o processo que o originou, uma vez que ele é resultado de um acúmulo de discussões e disputas anteriores no campo da educação e do trabalho no contexto da relação entre trabalho e capital. A questão legal que o precedeu, a sua formatação, implantação e as modificações sofridas no período, em particular na transição do governo Fernando Henrique Cardoso ao governo Luiz Inácio Lula da Silva, bem como os desdobramentos advindos dessa transição, que ainda estão em processo do ponto de vista das políticas públicas de educação e trabalho e continuam a intervir no Programa. 
O segundo capítulo aborda as diferentes visões/representações sobre o programa elaboradas por seus participantes (alunos, professores, equipe pedagógica, coordenação das entidades conveniadas e equipe diretiva do Departamento de Educação do Trabalhador). A análise dos discursos procurou apreender os conceitos referentes ao trabalho, à relação educação e trabalho, e as formas de apropriação de diversas dimensões do Programa.

As Considerações Finais apresentam as questões mais relevantes para a política pública que devem ser resolvidas ou respeitadas no que toca à educação de jovens e adultos e aos aspectos que a compõem. 


\section{CAPÍTULO 1 - CONTEXTO E IMPLANTAÇÃO DO PROGRAMA INTEGRADO DE QUALIFICAÇÃO}

\subsection{O PROCESSO HISTÓRICO QUE POSSIBILITA O SURGIMENTO DO PROGRAMA INTEGRADO DE QUALIFICAÇÃO}

\subsubsection{Breve histórico da educação de jovens e adultos e do ensino profissional}

No trajeto histórico da educação de jovens e adultos pode-se notar sua relação com a questão econômica e política dos diferentes momentos históricos. Pode-se perceber também a atuação do Estado e dos movimentos populares. Traçando um percurso histórico muito breve, Beisiegel (1997a, p.209) coloca que só a partir de 1940 pode se falar em políticas de educação de jovens e adultos no Brasil. Com o governo Vargas, em 1930, uma série de ações do Estado começam a se efetivar no sentido de criar uma infra-estrutura institucional para a execução de uma política de educação, mesmo que centralizada. De acordo com Cury (BRASIL, 2000, p.17), a Constituição de 1934 trazia em seu texto o reconhecimento da educação como direito de todos, incluídos os jovens e adultos: “A Constituição, ao se referir no art. 150 ao Plano Nacional de Educação, diz que ele deve obedecer, entre outros, ao princípio do ensino primário integral, gratuito de freqüência obrigatória, extensivo aos adultos (§ único, a)”.

$\mathrm{Na}$ década de 40, uma série de ações visando à destinação de recursos para o ensino primário veio a considerar o público jovem e adulto não escolarizado como parte da população que merecia atenção. O Decreto $n^{\circ} 19.513$, por exemplo, no item 2 de seu artigo $4^{\circ}$, estabeleceu que $25 \%$ de cada auxílio federal seria aplicado na educação primária de adolescentes e adultos analfabetos. Segundo Beisiegel (1997a, p.210):

Coroando este conjunto de iniciativas, através da Portaria n ${ }^{\circ} 57$, de 30 de
janeiro de 1947, o Ministério da Educação e Saúde autorizou a organização
de um Serviço de Educação de Adultos no Departamento Nacional de
Educação, possibilitando o início dos trabalhos da Campanha Nacional de
Educação de Adultos. Concretizava-se, assim, finalmente, já no Governo
Dutra, sob um novo arcabouço jurídico-político, uma campanha de educação
de jovens e adultos analfabetos cuja preparação fora iniciada ainda nos
tempos do Estado Novo.

O reconhecimento da educação de jovens e adultos como direito ocorre em momento histórico caracterizado por injunções e interesses políticos determinados. Como observa Cury (BRASIL, 2000, p.48), com o fim da ditadura estadonovista, "era importante não só 
incrementar a produção econômica como também aumentar as bases eleitorais dos partidos políticos e integrar ao setor urbano as levas migratórias vindas do campo". A política desenvolvimentista precisava considerar a grande parte da população que há pouco tempo vinha se incorporando à sociedade urbana e industrial. Se, por um lado, havia grupos que defendiam a idéia corrente de que uma sociedade iletrada representa maior possibilidade de controle e manipulação, por outro lado, havia aqueles setores dominantes que entendiam que impedir a população de se apropriar dos conhecimentos mínimos necessários com relação à leitura, escrita e cálculo era empecilho à realização de um projeto de desenvolvimento nacional em bases industriais.

Beisiegel (1997b) afirma que, com a Campanha Nacional de Erradicação do Analfabetismo no final da década de 50, há uma revisão da proposta de campanha anterior. Neste período, trava-se uma série de debates ideológicos e políticos e a educação de jovens e adultos faz parte deles.

A década de 60 trouxe uma grande contribuição para a educação de jovens e adultos, sendo um período caracterizado mais pelas iniciativas dos movimentos de educação popular do que pelas ações governamentais. O Movimento de Cultura Popular, criado em Recife, o Movimento de Educação de Base (ligado à Igreja Católica), a Campanha de Pé no Chão também se aprende a Ler, em Natal, e os Centros de Cultura Popular, da União Nacional de Estudantes, constituíam os principais movimentos que trabalhavam com educação de jovens a adultos, tendo em Paulo Freire a principal referência metodológica e política. Esses grupos pressionaram o governo federal a fim de que:

[...] os apoiasse e estabelecesse uma coordenação nacional das iniciativas, o que efetivamente ocorreu em meados de 1963. Logo depois foi criado o Plano Nacional de Alfabetização que previa a disseminação por todo o Brasil de programas de alfabetização orientados pelo já conhecido "Sistema Paulo Freire". (BRASIL, 2000, p.49)

A partir de 1964, este quadro muda profundamente. Mesmo com um projeto econômico desenvolvimentista - o "desenvolvimento capitalista associado"7 -, o golpe militar institui um governo autoritário que tinha como pressuposto básico a não participação popular, e praticamente todas as iniciativas neste sentido foram reprimidas. Algumas, como a experiência na cidade de Ubatuba, no estado São Paulo, ainda perduraram até 1968.

\footnotetext{
${ }^{7}$ Essa é a denominação atribuída por Delfim Neto à política econômica que implementou, que tratava de combinar o Estado, a empresa privada nacional e o capital estrangeiro para promover o desenvolvimento, com ênfase na industrialização. A esse respeito, ver FAUSTO, 2000.
} 
(BEISIEGEL, 1974, p.173) As ações legais referentes à educação de jovens e adultos do governo anterior foram revogadas e, como permanecia o problema de uma qualificação mínima da mão de obra nacional, foi criado o Movimento Brasileiro de Alfabetização MOBRAL em 1967. A partir de 1969 uma série de reformulações deu mais autonomia e poder ao MOBRAL:

Articulava-se assim, uma campanha de massa com controle ideológico e doutrinário, garantido pela centralização dos objetivos e das orientações e pela base conservadora das comissões locais, constituídas em geral por representantes das comunidades mais identificadas com o governo autoritário. (BEISIEGEL, 1997a, p.234)

Na década de 70, também se constituíram os Centros de Estudos Supletivos, para desenvolver as séries subseqüentes do primeiro grau. Estes Centros tinham o objetivo de atender aos alunos trabalhadores que não poderiam se adequar a uma escola regular por já estarem inseridos no mercado de trabalho e que, por isso, precisariam de formas alternativas de escolaridade. (BEISIEGEL, 1997a, p.236-237)

Com o processo de redemocratização do país, o MOBRAL é extinto e surge a Fundação Nacional para Educação de Jovens e Adultos - EDUCAR, em 1985. A partir da Constituição Federal de 1988, coloca-se novamente a educação de jovens e adultos no campo do direito civil, mas as ações governamentais apontam em outra direção, como nos mostra Beisiegel (1997a, p.239): "Não obstante a permanente reiteração dos direitos educacionais de todos os cidadãos, a União progressivamente abandonou as atividades dedicadas à educação de jovens e adultos analfabetos".

Na gestão Fernando Henrique Cardoso, duas ações principais estavam voltadas para o público da educação de jovens e adultos: o Programa Alfabetização Solidária, que propunha ações de alfabetização, por meio de convênio com o Ministério da Educação; e os programas envolvidos com a educação profissional de nível básico, financiados com recursos do Fundo de Amparo ao Trabalhador - FAT, do Ministério do Trabalho. Esses cursos, contavam com a "[...] forte presença das entidades do chamado Sistema S [...]". (BRASIL, 2000, p.52) Assim, o financiamento da educação de jovens e adultos, via Alfabetização Solidária, destinava-se a locais muito pobres e com características de campanha de alfabetização, e os programas de educação profissional de nível básico ofereciam, como alternativa à falta de escolaridade, cursos de qualificação profisssional de curta duração, que tinham como pressuposto a idéia de que a qualificação era garantia de emprego. O chamado discurso "da empregabilidade" afirmava que o desemprego ocorria por não haver pessoas qualificadas, e que a qualificação 
era responsabilidade individual. Dessa maneira, a formação imediata para o trabalho responderia às necessidades da população sem escolaridade.

A trajetória histórica da educação profissional, termo utilizado a partir da Lei de Diretrizes e Bases da Educação Nacional de 1996, tem estreita relação com a história da educação de jovens e adultos, no que toca a sua destinação. Se a EJA foi considerada, na maior parte de seu percurso histórico, uma política educacional não prioritária, destinada a uma parte da população que teria como "lugar social", o trabalho pouco qualificado, no que se refere à formação profissional, os objetivos desse tipo de ensino continuaram a ser os mesmos desde o seu início, o de propiciar à população conhecimentos prescritos à sua situação de classe. O histórico da educação profissional aqui apresentado não pretende ser completo, ou detalhado, mas fornecer as condições necessárias ao entendimento do quadro atual.

No início do século XX, o país passou por um importante período de transformações históricas. Impulsionados pela economia cafeeira, investimentos foram realizados no sentido de possibilitar o início da industrialização no país. O fim da escravatura e a política de imigração também modificaram o contexto nacional. Nesse período inicial (da proclamação da República aos anos 30), segundo Manfredi (2002), as modificações em curso e o aparecimento de novas necessidades de qualificação fazem com que educação escolar e o ensino profissional sejam reconfigurados. A educação profissional deixa de ser destinada aos necessitados, "desassistidos da sorte", e passa a ter, como objetivo, a formação de trabalhadores assalariados.

De acordo com Cunha (2000), em 1909, Nilo Peçanha, Presidente da República, baixou o decreto 7566, criando 19 escolas de aprendizes artífices, submetidas a uma legislação específica. Instalou-se uma em cada estado com exceção do Distrito Federal e Rio Grande do Sul, porque lá, já havia escolas. O público alvo era "a infância desvalida" e os "desfavorecidos da fortuna". Seria uma maneira de dar resposta ao movimento de reivindicação dos trabalhadores que se colocava. As escolas tinham a função de formar contramestres e operários, mesmo em estados fora da região Centro-Sul onde se estabelecia a maior concentração industrial.

Anteriormente a este período, em meados do século XIX, sociedades de auxílio e assistência a menores carentes instituíram em alguns estados os Liceus de Artes e Ofícios. Estes se instalaram no Rio de Janeiro, Bahia e São Paulo. Contavam, basicamente, com doações de seus sócios e em alguns momentos, com verbas públicas, dependendo da inserção de seus sócios junto aos governos. O Liceu de Artes e Ofícios de São Paulo merecerá destaque pelas características que passa a assumir. O Liceu de Artes e Ofícios de São Paulo, 
criado como entidade educacional privada em 1882, ascendeu institucionalmente em 1896, dois anos depois da inauguração da Escola Politécnica, com doações do governo paulista. Alterou sua direção inicial voltada à instrução "artística" e se voltou também ao ensino industrial. Em 1900, o Liceu passou a funcionar em novo prédio e oferecia atividades especificamente escolares e o curso de aprendiz, dentro de uma área tecnológica onde o aluno recebia instruções gerais relativas a uma especialização escolhida. Funcionava nos moldes industriais, com oficinas montadas para esse fim, inclusive com venda de produtos.

No plano da educação pública, no estado de São Paulo, nas décadas de 1910 e 1920 foram instituídas a Escola Profissional Masculina e a Escola Profissional Feminina. Em 1924 a Escola Profissional Masculina determinava como requisito para admissão o candidato ter cursado dois anos de escola primária. Os cursos oferecidos, com duração de três anos, incluíam mecânica, pintura decorativa, usinagem de metais, eletricidade e carpintaria, além das matérias escolares. (WEINSTEIN, 2000, p.52) Chama a atenção o elevado número de evasão, atribuído por seu diretor ao abandono do curso por motivos de trabalho. A autora levanta como uma das possibilidades para este abandono a precária escolaridade de seus alunos, que comprometia tanto a motivação quanto a compreensão, exigidas pela parte teórica, uma vez que estes conseguiam concluir o treinamento profissional. A Escola Profissional Feminina, por sua vez, apresentava excedentes de alunas. Baseada em uma concepção de que o ensino industrial e o trabalho qualificado na fábrica eram de domínio masculino, a Escola Feminina direcionou sua formação para o trabalho em pequenas oficinas e ateliês e seu currículo incluía economia doméstica e trabalhos artesanais para mulheres.

Em 1926, em portaria do Ministério da Agricultura e do Comércio, foi estabelecido um currículo comum para todas as escolas do sistema federal. Um dos motivos para essa padronização foi a crítica à improvisação dos diretores, despreparados para essa função. Outra importante alteração dessa nova regulamentação diz respeito ao caráter industrial que as escolas assumiriam, não do ponto de vista somente de seus objetivos instrucionais, mas da sua própria organização. Isso se deu em virtude da destinação a essas escolas de encomendas de órgãos públicos e entidades privadas, que lhes proporcionavam recursos para pagamento dos alunos e de outros funcionários, bem como o recolhimento de $20 \%$ sobre o serviço contratado.

Esta iniciativa e o oferecimento de merenda, a partir de 1922, reduziu o número de evasão, mas depois da década de 1920 as escolas entraram em decadência. Por concentraremse nos ofícios de sapataria, marcenaria e alfaiataria, afastaram-se do universo industrial preconizado inicialmente por seus propositores. 
Os anos de 1930 marcam novas mudanças no quadro da educação brasileira. De acordo com Cunha (2000), o Governo Provisório sob a responsabilidade de Getúlio Vargas procedeu a maior intervenção estatal na educação já vista. Foram criados o Ministério da Educação e Saúde e o Conselho Nacional de Educação. Importantes alterações foram colocadas ao ensino secundário, ensino superior e ensino comercial. As escolas federais de aprendizes e artífices, que se apresentavam como importante base para o desenvolvimento do ensino profissional, foram assumidas pelo Ministério da Educação.

Em dezembro de 1931 a Associação Brasileira de Educação promoveu a IV Conferência Nacional de Educação, de onde surgiu o Manifesto dos Pioneiros da Escola Nova. No Manifesto, com notada influência de Anísio Teixeira, a par de diferentes interesses presentes naquele momento, a maior crítica se dá no sentido da dualidade do sistema educacional brasileiro. $\mathrm{O}$ documento explicitava a concepção de diferenciação e estratificação social presente no sistema educacional, que propunha para a população a escola primária e profissional, e para a burguesia, a escola secundária e superior. Cunha (2000) aponta que com relação ao ensino profissional, o documento deixava claro que crianças não deveriam ser submetidas a ele, propondo que a formação para o trabalho se desse no local do próprio trabalho. No que toca ao ensino secundário, o documento também fazia críticas, no sentido de apontar que este seria o ponto nevrálgico do sistema, na verdade, nele ficaria caracterizada a existência do que seriam esses dois sistemas de ensino. Reivindicava que este nível fosse unificado, a fim de evitar a separação entre trabalhadores manuais e intelectuais. Propunha que os três primeiros anos fossem de formação cultural básica comum, para posterior bifurcação com uma rede de programas variados, para atender as diferenças individuais. Assim, estariam atendidas as exigências intelectuais e a preparação profissional.

Na Assembléia Constituinte de 1933, Anísio Teixeira e os educadores progressistas foram vencidos e as posições do Manifesto rejeitadas, principalmente em relação à eliminação da dualidade do sistema, ao ensino laico e a predominância da escola pública.

Em 1934 Gustavo Capanema foi nomeado para o Ministério da Educação e Saúde. Um processo crescente de centralização das ações do governo federal entrou em curso. A Constituição de 1934 reconhecia os sistemas estaduais de educação, e impôs a estes a aplicação de $10 \%$ e, aos municípios, $20 \%$ dos recursos orçamentários em seus sistemas de educação, sendo que o Estado teria uma ação supletiva no caso de carência de recursos. Os estados deveriam reconhecer e atender as diretrizes estabelecidas no governo federal.

No estado de São Paulo, desde a década de 1910, duas posições se colocavam na orientação da formação profissional. Não eram antagônicas, visto que partilhavam de alguns 
aspectos em comum, mas diferenciavam-se em relação ao público a ser atendido. Em 1923, o Liceu de Artes e Ofício implantou a Escola Profissional Mecânica, primeira do estado totalmente voltada para profissões mecânicas e tinha como público alvo os trabalhadores das estradas de ferro. Seu responsável, Roberto Mange, implantou as chamadas "séries metódicas", baseadas nos "métodos de organização científica do trabalho" difundido pelo taylorismo. Afirmava ele, que este método rompia com a idéia da formação em serviço, de característica empírica. (WEINSTEIN, 2000) Esses princípios, para além da execução do trabalho, dizem respeito também a disciplinarização do trabalhador. Como coloca Bryan, para Taylor "não interessa o trabalhador que só trabalha quando vigiado - mas mediante a interiorização da norma que preside à elaboração da tarefa ensinada pelo supervisor". (1992, p.48) Nesse sentido, a formação profissional incorpora a disciplina fabril, a fim de conformar o trabalhador à disciplina da fábrica. Disciplina esta necessária para um sistema de produção baseado em tempos e movimentos, determinados não pelo trabalhador, mas pelo ritmo da produção. Isso vinha ao encontro da crescente industrialização em São Paulo e seria uma maneira de formar os trabalhadores para as atividades industriais, afastando a idéia do trabalho manual como trabalho menos digno, advinda do período da escravidão.

Nessa direção, como também indica Moraes (2003), foi criado o Instituto de Organização Científica do Trabalho - IDORT, tendo como orientador o professor Leon Walter, a pedido da Associação Comercial de São Paulo, com o objetivo de ministrar cursos e adaptar a produção aos princípios da organização científica do trabalho. Cunha (2000) mostra que o IDORT foi fundado em 1931, com o patrocínio da Associação Comercial e da Federação das Indústrias de São Paulo. Exerceu importante influência na área educacional, o que pode ser avaliado por sua participação na organização do Centro Ferroviário de Ensino e Seleção Profissional - CFESP, em 1934. Essa experiência influenciou diretamente a modificação da estrutura do ensino profissional público no estado, conforme coloca Moraes (2003). O CFESP tinha uma ação que se diferenciava das escolas de aprendizes, como aponta Cunha (2000), por ter um público mais restrito, principalmente os filhos dos ferroviários, e um ensino direcionado ao trabalho nas estradas de ferro, diferentemente das escolas federais de aprendizes, que tinham um público que procurava mais a assistência social do que a formação profissional. Além disso, a associação do Estado com as empresas dava-lhe um caráter de formação estrita para o trabalho, formando pessoal para estas.

De outra parte, segundo Weinstein (2000) o diretor da Escola Profissional Masculina da Capital, Aprígio de Almeida Gonzaga, defendia, como Mange, a necessidade de serviços complementares aos alunos como meio de criar trabalhadores física e mentalmente saudáveis 
e também era um crítico do caráter empirista da formação profissional tradicional e defendia a “formação completa do trabalhador". No entanto, sua semelhança com Mange se encerra aí. Via com reservas as inovações que pudessem comprometer a posição do operário qualificado. Criticava a utilização de mão-de-obra feminina e infantil na indústria, que considerava ser responsável por baixar os salários dos homens. Aprovava o princípio da organização sindical, como meio de fortalecimento dos trabalhadores e de interferência nos problemas políticos e econômicos do Estado. Apresentava uma visão negativa do impacto social da indústria e preocupava-se com a "especialização" dos trabalhadores, uma vez que, para ele, o completo conhecimento de uma função era a única garantia contra a mecanização das funções manuais. Mange, diferentemente, atribuía à formação profissional o papel de conformar o trabalhador às necessidades de mão de obra da indústria.

A idéia da formação profissional baseada na "organização científica do trabalho" ganha espaço no estado, alimentada pelo projeto industrialista, e as posições de Aprígio Gonzaga são relegadas.

Estas idéias se inserem no plano federal, após o período de relações conflituosas do início da década de 1930. No final da década, constrói-se uma estreita relação entre os industriais defensores da racionalização e o regime de Vargas, principalmente através de Roberto Simonsen.

Em 1934 os Ministérios do Trabalho e da Educação criaram uma comissão para formular um "Plano de Formação Profissional". Entre os participantes, entre outros, estavam Roberto Mange, Lourenço Filho e Rodolpho Fuchs, inspetor da educação industrial. (WEINSTEIN, 2000) Foi se estabelecendo um consenso sobre como deveria ser a educação profissional, na perspectiva de atendimento às demandas industriais, posição endossada pelo Ministério do Trabalho, mas que encontrava resistências no Ministério da Educação. Este apresenta uma proposta para a formação profissional, que é criticada por Valdemar Falcão, Ministro do Trabalho, por ser grandiosa e por isso dispendiosa. Em 1940, Capanema se dirige a Vargas, colocando sua oposição a uma educação profissional que privilegiava a educação dos operários em função da demanda industrial e do papel marginal que seu Ministério teria. Vargas propõe uma nova comissão para desenvolver o ensino industrial que conta, entre outros, com a participação de Roberto Simonsen, Euvaldo Lodi e com assessoria de Roberto Mange e outros.

Simonsen propõe então, que o financiamento do programa de treinamento fique a cargo da classe dos industriais, que não foi bem aceito por Capanema, mas recebeu receptividade do Ministro do Trabalho e do próprio Vargas. A comissão propôs a criação do 
Serviço Nacional de Seleção, Aperfeiçoamento e Formação de Industriários (SENAFI). Os recursos seriam oriundos de contribuições mensais das indústrias e os representantes dos ministérios participariam dos conselhos regionais e nacionais, e o governo expediria certificados a graduados e instrutores. (WEINSTEIN, 2000) Em 22 de janeiro de 1942, Vargas e os ministros da Educação e do Trabalho promulgaram o decreto-lei $n^{\circ} 4048$ criando o SENAI. As oposições de Capanema afetaram muito parcialmente o programa, apenas em seu nome: Serviço Nacional de Formação de Industriários. Fuchs também lamenta a forma final da proposta, uma vez que sua preocupação era que a formação industrial promovesse a disciplina, o controle social e a integração do operário no desenvolvimento nacional e não apenas o aperfeiçoamento técnico da mão de obra requerida pela indústria.

Desta maneira, a experiência da Escola de Mecânica, do Liceu de Artes e Ofícios de São Paulo e suas diretrizes e orientações encampadas pela escola do Centro de Ferroviários, se expande por todo o setor industrial.

O decreto-lei 4073 de 1942 delimitou ao ensino primário o caráter exclusivamente geral e passou para o grau médio o ensino profissional. As escolas de aprendizes artífices recrutavam os alunos provavelmente menos preparados ou dispostos a prosseguir a escolarização, devido sua origem social. Essas escolas foram posteriormente enquadradas na "lei” orgânica e deram origem às escolas industriais da rede federal.

Ainda segundo Cunha (2000), o SENAI deixou de ocupar um lugar de apêndice do sistema e depois de duas décadas passou a ocupar uma posição hegemônica na formação de operários qualificados. Demonstrou executar as tarefas da escola industrial de maneira mais flexível, por não estar atrelado à burocracia educacional estatal. Acompanhava de melhor forma, em termos de oficinas, professores e métodos, as demandas colocadas pelo setor produtivo. Além disso, mantinha estreita relação com as indústrias, inclusive com remuneração de alunos.

Com o fim do Estado Novo, retornam ao governo os educadores liberais, entre eles, Anísio Teixeira. As escolas da rede federal sofreram importantes alterações a partir da lei 3559 de 1959 e do decreto 47038, que a regulamentou. A principal modificação, como mostra Cunha (2000) dizia respeito à perda de caráter profissional do curso industrial e que fosse reconhecido como curso adequado a formação de operários qualificados os cursos de aprendizagem, perdendo a posição subalterna que tinham. Isso ia ao encontro da hegemonia do SENAI na formação profissional.

A Lei de Diretrizes e Bases da Educação de 1961 trabalhou na unificação de todos os ramos de ensino do $1^{\circ}$ ciclo do ensino médio. O curso industrial, dessa maneira, se aproximou 
do curso secundário, e este, por sua vez, se aproximou do primeiro, com a introdução de uma disciplina vocacional em seu currículo. De 1961 a 1965 o Ministério da Educação fez diversas alterações, com projetos de ginásios baseados na experiência do Distrito Federal entre 19332/35, com uma estrutura curricular semelhante, porém abandonando o discurso socialista e assumindo as características da educação americana. O curso tinha quatro anos de duração, com os dois primeiros anos de formação geral e algumas disciplinas vocacionais a fim de sondar a aptidão do aluno e nos dois últimos anos aumentavam a carga horária das disciplinas vocacionais.

De acordo com Cunha (2000), com o golpe de estado em 1964, mais modificações ocorreram, inclusive com o financiamento conseguido através de acordos entre o Ministério da Educação e a United Agency for International Development - USAID. Com a promulgação da Lei de Diretrizes e Bases da Educação, 5692/71, institui-se o $2^{\circ}$ grau, antigo ensino médio que contaria com três anos de duração e teria um caráter compulsoriamente profissional, sem ramos paralelos, mas com cursos distintos, a partir de um núcleo comum. Com relação a ensino supletivo, este abrangeria a suplência da escolarização regular para os que não a concluíram, bem como o suprimento de conhecimentos, técnicas ou habilidades. Nesta última denominação foram incluídos os cursos de aprendizagem industrial.

Ainda conforme Cunha (2000), a compulsoriedade da profissionalização no $2^{\circ}$ grau se deu com a intenção de resolver duas questões: a crescente busca pelo ensino superior que não conseguia atender à demanda e a suposta carência de pessoal de quadro técnico, já que esses postos eram ocupados por pessoas com nível escolar mais elevado ou por "práticos", sem os devidos níveis de escolaridade. O modelo a seguir seria os das escolas técnicas industriais, que gozavam de grande reconhecimento.

No entanto, a intenção inicial presente não se confirmou. Os quadros técnicos eram preenchidos por pessoas com nível superior, por estes não encontrarem emprego, e não por falta de quadros técnicos. A ausência de recursos humanos e materiais impediram que a reforma fosse implantada como deveria, porque as escolas não teriam condições de acompanhar as demandas regionais por quadros técnicos. Mesmo que tivessem recursos e pessoal para isso, este acompanhamento das demandas econômicas não lhes seria possível.

As escolas das redes estaduais sofreram grandes danos com essa nova determinação. As escolas da rede federal sentiram menos os seus efeitos, pela resistência que apresentaram ao novo modelo. Em contrapartida, as escolas particulares, através de uma profissionalização “disfarçada”, preparavam seus alunos para os exames vestibulares. 
Apesar da posição ditatorial do governo, resistências e críticas se colocaram a este modelo. Algumas alterações foram realizadas em seu percurso, mas foi no período de abertura política, com a lei 7044/82 que se alterou em dada medida o caráter do $2^{\circ}$ grau. O objetivo da qualificação para o trabalho foi substituído por preparação para o trabalho, o que retirou a obrigatoriedade da habilitação profissional.

Neste quadro, não poderia faltar a atuação do SENAI. Durante esses anos, conforme mostra o mesmo autor, ele atuou em direção radicalmente oposta às escolas federais. Enquanto estas defendiam um ensino mais generalista, o SENAI, em contrapartida, passou a atuar no ensino técnico de $2^{\circ}$ grau com, a instalação de escolas especializadas. Durante os anos de 1970, com a alteração das técnicas produtivas, essa agência passou a investir mais na semi-qualificação através de cursos rápidos para adultos.

Em seguida, a nova Lei de Diretrizes e Bases da Educação de 1996 vai realizar uma nova alteração no quadro da educação, principalmente no que diz respeito ao ensino profissional e ao $2^{\circ}$ grau.

Com a pretensão de abordagem mais analítica do que descritiva, o tópico que se segue abordará o período do governo Fernando Henrique Cardoso e a transição ao governo Luiz Inácio Lula da Silva, sob a égide da Lei 9394/96.

\subsubsection{O Governo Fernando Henrique Cardoso e a transição para o Governo Luiz Inácio} Lula da Silva

A análise da educação profissional requer necessariamente que se discuta a relação educação/trabalho. Este debate não é novo e nem está resolvido. E não está resolvido porque tratar da relação entre educação e trabalho implica tomar posições e perspectivas sobre o que, diferentemente dos que apregoam o "fim da história", está acontecendo sob a dinâmica capital $\mathrm{X}$ trabalho. O trabalho, na sua forma dominante na sociedade de classes, é trabalho expropriado e alienado.

Isso quer dizer que defender qual conformação deve ter a educação profissional, para usar o termo colocado na Lei de Diretrizes e Bases da Educação de 1996, implica assumir uma perspectiva de classe, mesmo que se diga o contrário. Por estar a educação profissional diretamente relacionada ao mundo do trabalho, defender este ou aquele projeto de educação profissional explicita a perspectiva política e ideológica de determinado grupo. 
Nesse sentido, a disputa entre os diferentes grupos e como se dá a articulação de forças para se consolidar, na forma da Lei, uma dada perspectiva, é um processo que está permanentemente em curso. Há um tema central no campo da educação profissional que é o trabalho. E a distinção necessária a ser feita é o trabalho enquanto categoria ontológica do ser humano e o trabalho na forma que assume nos diferentes períodos históricos. Essa distinção deve ser colocada uma vez que esse entendimento embasa as perspectivas políticas presentes nos projetos de educação profissional. Como colocam Frigotto, Ciavatta e Ramos:

[...] é preciso fazer uma distinção entre o trabalho como relação criadora do homem com a natureza, o trabalho com atividade de autodesenvolvimento físico, material, cultural, social, político, estético, o trabalho como manifestação de vida, e o trabalho nas suas formas históricas de sujeição, de servidão ou de escravidão, ou do trabalho moderno, assalariado, alienado, forma específica de produção da existência no capitalismo. (2005, p.26)

Fazer a conceituação do trabalho é indispensável para a compreensão do que se coloca nos diferentes projetos de educação profissional, uma vez que em muitos documentos oficiais o entendimento do que é o trabalho é colocado na sua dimensão imediata, estritamente ligado às demandas do mercado. O trabalho dessa maneira é entendido como necessidade do mercado e não como possibilidade de realização humana.

Esse entendimento do que é o trabalho gera, por sua vez, uma forma de ver a educação profissional como mero preparo para as tarefas advindas das necessidades da produção. As mudanças implantadas durante a gestão de Fernando Henrique Cardoso, como serão colocadas no decorrer deste texto, mostram que tais ações educativas não são destinadas à sociedade como um todo, mas para uma determinada parcela da sociedade. Ao colocar a orientação presente durante este governo, Cunha, referindo-se a Cláudio de Moura e Castro, que foi assessor do ministro da Educação na primeira gestão FHC, afirma que:

O economista não tinha dúvida de que o "sistema inglês" era o mais adequado para o Brasil, ou seja, ensino acadêmico para uns e ensino profissional para outros, os que, oriundos da classe operária, não tivessem se contaminado com os valores das classes médias e alta, que desconsideram as "ocupações manuais". (2000, p.245)

Não só o entendimento do que é o trabalho, mas também a dimensão do direito à educação, estão recortadas por uma perspectiva de classe e sociedade que informam a proposta de educação profissional. 
É necessário levantar alguns pontos importantes que o conjunto das mudanças trouxe ao contexto da educação profissional no Brasil.

As proposições para a educação profissional, no governo FHC, foram designadas como o "novo", como "avanço conceitual". Para contextualizar as mudanças propostas é preciso observar as normas legais implementadas, principalmente a nova Lei de Diretrizes e Bases da Educação - Lei no 9394/96 e o Decreto n ${ }^{\circ}$ 2.208/97. Este último dividiu a educação profissional em três níveis: básico (qualificação e requalificacão profissional independente da escolaridade), técnico (destinado a habilitar profissionalmente alunos matriculados ou egressos do ensino fundamental) e tecnológico (corresponde a cursos de nível superior, destinados a egressos do ensino médio e técnico).

Na nova LDB, a educação profissional, enquanto uma modalidade de ensino, coloca em seu Artigo 40 que “a educação profissional será desenvolvida em articulação com o ensino regular ou por diferentes estratégias de educação continuada, em instituições especializadas ou no ambiente de trabalho". Apesar de colocada como modalidade, este artigo possibilita a separação da educação profissional da educação básica, mesmo afirmando que ela se dará de forma articulada.

Com o Decreto $n^{\circ}$ 2.208/97, que normatiza o capítulo da LDB que trata da educação profissional, explicitam-se os desdobramentos dessa separação. Nele está contida a concepção desse governo, presente em seus objetivos:

Promover a transição entre a escola e o mundo do trabalho, capacitando jovens e adultos com conhecimentos e habilidades gerais e específicas para o exercício da cidadania e das atividades produtivas.

Essa transição entre a escola e o mundo do trabalho e essas habilidades gerais e específicas presumem um trabalho coordenado e contínuo da formação geral, que desenvolve as competências básicas concomitante com a compreensão dos fundamentos científico-tecnológicos dos processos produtivos, relacionando a teoria com a prática.

Há, também, nos objetivos dessa política educacional uma inovação de extrema importância tanto social como econômica: a qualificação, a reprofissionalização e a atualização de jovens e adultos trabalhadores, com qualquer nível de escolaridade, visando conferir melhores condições de trabalhabilidade a essa clientela. (BRANDÃO, 2002, p.133)

É possível verificar na denominada "nova conceituação" o uso de termos como competências e trabalhabilidade. Vale a pena ressaltar que a educação profissional de nível básico, destinada a jovens e adultos de baixa escolaridade, visando "conferir melhores condições de trabalhabilidade", como colocado acima, torna-se praticamente a única alternativa educacional (pode-se chamar assim) oferecida pelo governo federal a essa 
população, uma vez que a educação de jovens e adultos também tratada como uma modalidade pela LDB, não era destinatária de recursos:

$\mathrm{Na}$ verdade, o teor da Lei $\mathrm{n}^{\circ}$ 9.424/96 que regulamentou a Emenda ${ }^{\circ}$ 14/96 deixa de fora do cálculo do Fundo de Manutenção e Desenvolvimento do Ensino Fundamental e Valorização do Magistério (FUNDEF) a Educação de Jovens e Adultos. O FUNDEF se aplica tão só ao ensino fundamental no momento em que muitos trabalhadores e mães de família, afastados dos estudos por longos anos, pressionam por uma entrada ou retorno na educação escolar, seja para melhorar a renda familiar, seja para a busca de mobilidade social. (BRASIL, 2000, p.22-23)

A esse respeito, Frigotto, Ciavatta e Ramos (2005) consideram que o resgate do direito à educação deve se dar na forma de processos formativos integrados de educação básica simultaneamente à qualificação profissional.

Com relação ao nível técnico, em seu Artigo 50, o decreto coloca "A educação profissional de nível técnico terá organização curricular própria e independente do ensino médio, podendo ser oferecida de forma concomitante ou seqüencial a este". Uma das decorrências dessa mudança foi transformar a educação profissional em um sistema paralelo (CUNHA, 2001), o que "reafirma a antinomia entre formação geral e formação técnica, impedindo a construção de uma educação politécnica ampla, condizente com os requisitos da cidadania" (MORAES, 1999).

No discurso governamental, a justificativa para a utilização do termo educação profissional é a de designar o conjunto ampliado das ações de formação profissional. Ao colocar que a educação profissional diz respeito à integração entre educação formal e trabalho, concentra sua orientação para as chamadas habilidades e competências que a reestruturação produtiva exige. E, nesse sentido, aponta o caráter deficitário da escola formal, uma vez que esta, por ter finalidade propedêutica, não consegue acompanhar as mudanças que ocorrem no mundo do trabalho, e não consegue capacitar os trabalhadores adequadamente. A separação entre educação formal e educação profissional possibilita então que, como nível pós-médio e/ou modalidade de ensino, a formação técnica assuma vínculo direto com o mundo do trabalho, apresentando maior eficácia e eficiência no atendimento às demandas do mercado, na perspectiva da Teoria do Capital Humano, que correlaciona investimento em educação e produtividade econômica ${ }^{8}$.

\footnotetext{
${ }^{8}$ Sobre a incidência da Teoria do Capital Humano na reforma educacional do governo FHC, consultar MORAES, 2001.
} 
Outro argumento utilizado é o de que as escolas técnicas da rede federal apresentavam custos muito elevados, para resultados mais propedêuticos do que profissionais.

A proposta curricular, na perspectiva colocada acima, pauta-se no "modelo das competências", visto como capaz de garantir a condição de empregabilidade ao aluno. Acerca da noção de competência é preciso ressaltar que, embora não haja consenso quanto a seu significado técnico ou de método, apresenta forte convergência em relação ao conteúdo político. Ao se proporem a substituir o conceito de qualificação, como observa Moraes (1999), as diferentes definições de competência "apresentam em comum o fato de não incluírem a idéia de relação social que está presente no conceito de qualificação".

A noção de qualificação se relaciona, portanto, àquela de negociação social,
de convenção coletiva de trabalho. Agora, fala-se de competência e se
considera o indivíduo no trabalho, o seu desempenho (verificável) em
situação de trabalho. A tendência é atribuir-lhe o sentido de performance
individual, o que indica um deslocamento importante em direção à
individualização crescente de apreciação dos assalariados. (MORAES, 1999,
p.25)

A individualização da relação entre trabalhador e empresa, tende a fragilizar sua capacidade organizativa colocando à mercê das exigências empresariais a sua atuação e a sua formação. Esse modelo integra o conjunto das ações que visam a flexibilizacão dos direitos do trabalhador. Ele perde a força de reivindicação e negociação enquanto categoria ou classe, ao se individualizarem as relações de trabalho. A esse respeito, referenciando-se em Enguita, Moraes observa que "são as opções organizativas que definem a qualificação do posto de trabalho e a autonomia do trabalhador - o que tem importantes conseqüências para a adoção das políticas empresariais, de emprego e de formação”. (2005, p.49)

A perspectiva da individualização está presente, também, no conceito de empregabilidade. O trabalhador deve ser o responsável por sua condição de ser empregável ou não. A questão do emprego deixa de pertencer ao campo da política econômica e das políticas públicas de emprego e passa a ser vista como responsabilidade do trabalhador. Nesse sentido, para que um trabalhador tenha empregabilidade, ele deve estar qualificado de acordo com os requisitos do mercado. Omite-se, no entanto, que o fato de o trabalhador ser qualificado não lhe garante o emprego, pois como inúmeras pesquisas têm indicado “[...] é crescente o número de trabalhadores qualificados desempregados". (MORAES, 1999, p.26) Além disso, a empregabilidade requer, além da qualificação ou requalificação, a ampliação da escolaridade. 
Para Frigotto, Ciavatta e Ramos (2005, p.44), a formação e a educação básica requeridas devem estar em consonância com

[...] competências e habilidades no plano do conhecimento, das atitudes e dos valores, produzindo capacidades para gestão da qualidade, para a produtividade e competitividade, elementos não mais da aquisição do emprego e qualificação profissional, mas elementos da empregabilidade.

Em resumo, no discurso governamental e empresarial do período, competências e empregabilidade são conceitos que expressam mudanças a serem alcançadas muito mais nas atitudes e no comportamento do trabalhador do que propriamente nos requisitos técnicos. A intenção parece ser a de minimizar o caráter coletivo do trabalho no que tange à possibilidade de organização dos trabalhadores, individualizar a relação trabalhador/empresa e conformar, em termos de "novos" valores e atitudes, a educação e a qualificação profíssional no contexto da flexibilização do trabalho.

No que se refere à gestão da educação profissional, ocorre sua gradativa privatização, prática adotada pelo governo, que assume postura neoliberal. Os centros públicos de educação profissional (depois denominados de centros de formação profissional, seguindo terminologia assumida pelo MEC) apresentam um modelo de gestão que se estende às escolas técnicas da rede federal, e têm como objetivo incorporar a "comunidade". Segundo Cunha (2002, p.120):

A idéia dos centros públicos de educação profissional, da Sefor/MTB, foi incorporada pelo MEC, via Semtec, mas depurada de um eventual viés estatista. Ao contrário da idéia original, a orientação privatizante fica patente na prescrição às escolas da rede federal para que incluam empresários em seus conselhos (e trabalhadores, talvez para meia compensação), que façam parcerias com empresas e outras entidades privadas, que gerem recursos vendendo cursos e outros serviços, que contratem pessoal fora das normas do serviço público, enfim, que liberem os orçamentos do governo.

De acordo com esse autor, o programa visou "à implementação e/ou a readequação de 200 centros de educação profissional, distribuídos da seguinte forma: 70 na esfera federal, 60 na estadual e 70 no "segmento comunitário"”. (CUNHA, 2002, p.118)

$\mathrm{Na}$ concepção da Secretaria de Formação (SEFOR), estes centros deveriam atingir diferentes faixas da população. Eles não se referiam apenas à rede federal, mas abrangeriam diversos tipos de instituição. Além das atribuições pedagógicas referentes às escolas técnicas federais, tais centros deveriam desenvolver um conjunto de ações que atendessem a trabalhadores com qualquer nível de escolaridade, principalmente aos que estivessem em 
situação de trabalho precário. A SEFOR defendia que esse termo qualificaria instituições já existentes ou a serem criadas, com características pouco definidas. As atividades incluíam:

Educação acadêmica e técnica de curta, média e longa duração; programas de qualificação e requalificação em bases contínuas e modulares; extensão cultural e tecnológica; assessorias e serviços (laboratórios, oficinas, fazendas); serviço de orientação, acompanhamento e avaliação; serviço de intermediação, geração de renda, orientação trabalhista e seguro desemprego. (CUNHA, 2002, p.236)

É importante destacar que, apesar do espaço restrito de participação nas discussões acerca da definição das políticas de educação e trabalho, a Central Única dos Trabalhadores CUT defendia a organização desses centros como espaços públicos. Uma das resoluções da $7^{\mathrm{a}}$ Plenária Nacional da CUT (1995), sobre Formação Profissional, definia os Centros Públicos de Ensino Profissional como locais onde se realizariam atividades voltadas ao desenvolvimento humano, que atendesse às demandas específicas de qualificação de jovens e adultos. Com relação ao ensino profissional para jovens com idade escolar, preconizava a luta pela vigência do Estatuto da Criança e do Adolescente, contra o trabalho infantil e pelo direito ao acesso e permanência na escola. Entendia ser necessário o estabelecimento de uma renda mínima, como forma de garantir a freqüência de crianças e jovens à escola. Propunha também aos jovens a oferta do acesso a modalidades de ensino profissional e cursos de atualização científica e cultural, não substituindo, mas complementando a escolaridade formal. No que toca à educação continuada, esses Centros deveriam ofertar atividades e cursos de alfabetização e pós-alfabetização, de qualificação e requalificação profissional a trabalhadores empregados e desempregados, bem como cursos de atualização científica, artística e cultural . Deveriam também, em sua proposta de qualificação e requalificação, propiciar “[...] a apropriação crítica de conhecimentos científicos e tecnológicos e de saberes mais gerais sobre o homem e a sociedade, imprescindíveis na conformação da cidadania", diferentemente do SENAI, que trabalha na perspectiva adaptativa dos trabalhadores às relações de trabalho. (MORAES, 1997)

O conjunto das ações indica que o governo toma como referência para a educação profissional o modelo aplicado pelo SENAI, tanto no que se refere à subordinação as exigências do mercado, através da participação dos empresários em sua administração, quanto no que toca ao modelo curricular, desenhado para atender as necessidades de treinamento de mão-de-obra qualificada. A forma instituída no SENAI prevê a participação de empresários 
da região onde se localiza em seus conselhos administrativos, de maneira que estes possam orientar seus rumos de acordo com as empresas locais. (MORAES, 2001, p.24)

Se as propostas mencionadas acima refletiam o projeto político e econômico-social do governo FHC, por outro lado, todo o período caracterizou-se pela disputa entre diferentes concepções da educação/qualificação profissional.

É preciso mencionar que o projeto de educação profissional do governo, em particular o Plano Nacional de Formação Profissional - PLANFOR, do Ministério do Trabalho, com todos os seus problemas, possibilitou que sindicatos e organizações populares, tendo acesso a financiamento público, elaborassem e executassem propostas alternativas de educação profissional pautadas, por um outro entendimento de educação e de trabalho, e de sua relação. Essas experiências serviram como referência para a elaboração de políticas públicas de educação/formação profissional, nos anos 1990, em algumas administrações públicas municipais e estaduais. Moraes (2001) refere-se a duas experiências realizadas nesse campo: os Programas "Integrar", realizado pela CNM/ CUT ${ }^{9}$, com assessoria da PUC-SP; e "Educação dos trabalhadores pelos trabalhadores", desenvolvido pelo Centro de Educação, Estudos e Pesquisas - CEEP, em parceria com o Centro Estadual de Educação Tecnológica Paula Souza. Guardadas algumas especificidades entre os dois programas, as duas experiências tinham em comum a defesa da formação integral do trabalhador, e o entendimento de que a formação para o mundo do trabalho não se restringe à qualificação de mão-de-obra para o mercado.

É importante mencionar que, na CUT, houve alguns embates no que concerne à concepção e definição de uma política de educação e formação profissional destinada a trabalhadores. Duas proposituras colocadas, decorrentes de diferentes correntes que compunham a Central, estavam no centro da disputa.

Segundo um dos documentos da CUT, intitulado "Trabalhadores e Educação: Organização e Construção da Cidadania” (FELIX; MORAES; AGUIAR, 1993), a Comissão de Educação da CUT, estruturada em 1992, promoveu uma série de discussões tendo como tema "Educação e Trabalho". Nessas discussões estiveram envolvidos diversos setores da CUT (Comissão Nacional de Automação e Tecnologia, Departamentos e Confederações Nacionais dos diferentes ramos de atividades, Departamento de Estudos Sócio-Econômicos da CUT - DESEP, Secretaria Nacional de Formação), representantes do DIEESE e alguns representantes sindicais. Das discussões desse grupo resultou o documentou "Diretrizes para

\footnotetext{
${ }^{9}$ Confederação Nacional dos Metalúrgicos/ Central Única dos Trabalhadores.
} 
uma política de formação profissional da CUT", que teve sua primeira versão revista pelo grupo, e uma segunda versão que foi apresentada à Direção Nacional da CUT, sob a responsabilidade dos mesmos, os representantes da ANDES-SN na Comissão. Um outro documento também foi entregue à Direção Nacional, denominado "Contribuição para a definição de uma política de formação profissional da CUT", elaborado por Sebastião Lopes Neto (membro da Executiva Nacional) e Carmen Sylvia Vidigal Moraes (membro da diretoria da ADUSP - Seção Sindical da ANDES-SN). Nesses dois documentos ficam explicitadas as convergências e divergências sobre a formação profissional então existentes na CUT, e que foram referenciais nas discussões da Comissão de Educação, ocorridas em 1993.

No Seminário Internacional de Belo Horizonte, em 1993, organizado a fim de se proceder ao debate, foram discutidos os dois documentos. Participou também a entidade Instituto Sindacale per la Cooperazione allo Svilupo e a Confederação Internacional de Sindicatos Livres - ISCOS/CISL, presença justificada pela necessidade de conhecimento crítico da racionalidade capitalista internacional, principalmente nas sociedades capitalistas avançadas, o que contribuiria para o debate.

No que toca propriamente às discussões, dentre as questões que não havia divergências estava a defesa da escola pública, gratuita e de qualidade.

No campo das convergências está também a defesa de que a responsabilidade pela formação profissional deveria ser pública, não significando com isso que devesse ser oferecida exclusivamente pelo Estado, mas que as iniciativas deveriam estar sob seu controle direto. Ao mesmo tempo, se colocava a necessidade de ampliar o controle dos trabalhadores sobre as instâncias do Estado que gerissem as políticas e recursos educacionais. Avaliavam também que o contexto histórico e político do momento, não favorecia a proposta de extinção dos "Serviços Nacionais" de formação profissional, então a estratégia colocada era a de propor a gestão tripartite desses Serviços, com o controle fiscal dos recursos públicos.

As diferenças se colocaram no que diz respeito à relação do movimento sindical com o Estado e ao entendimento de "público" e "estatal". A maior polêmica se concentrou em torno das escolas profissionais mantidas pelos sindicatos e principalmente na questão da oferta de formação profisssional aos jovens. O documento da Comissão de Educação intitulado "Diretrizes para uma política de formação profissional da CUT" entende que atuação da CUT não seria a de estimular os sindicatos para que investissem em formação profissional, uma vez que este não era o seu papel, mas, sim, o de elaborar propostas de formação/educação que constassem das negociações coletivas. Viam a criação de escolas profissionais pelos sindicatos, com fundo público, como a repetição do que ocorre com o Sistema S (SENAI, 
SENAC e afins). Defendiam que o papel da CUT deveria ser o de lutar pela escola pública de qualidade, que atendesse à demanda existente. Deveriam ser criadas formas de pressão para que através de negociação coletiva se incluísse a questão da formação profisssional. Defendiam, então, como ação central, que a CUT lutasse no Congresso pela subordinação do Conselho Nacional de Formação Profissional ao Conselho Nacional de Educação e orientar-se pelo princípio de que todas as iniciativas educacionais estivessem ligadas a um Sistema Nacional de Educação.

O documento elaborado por Sebastião Lopes Neto e Carmen Sylvia Vidigal Moraes apresentava, como entendimento diferenciado do colocado no documento referido acima, a oferta de ensino profissional por centros públicos ou privados de formação profissional, por associações sindicais, comunitárias e populares, e em nenhum momento, desconsiderando a necessidade do acesso à escola básica, inclusive, salientando que sem a garantia de formação de caráter básico, o ensino profissional tende a ser mero adestramento. Por isso, a defesa do ensino profissional articulado ao sistema regular de ensino. Essa proposta baseava-se no fato de que há uma realidade inerente ao trabalho que coloca as classes trabalhadoras em condições muito precárias de vida e que a defesa da escola regular, pública e gratuita, somente, não dava conta dessa situação. O texto aponta que por ocasião da discussão da nova LDB, um grupo de pessoas, entre as quais as mesmas que redigiram o documento da Comissão de Educação, preocupadas em combater propostas que tratavam o ensino profissional na perspectiva única e exclusiva da formação de mão-de-obra, equivocadamente defenderam a supressão do Capítulo XI que tratava da Formação Técnica e Profissional, presente no Projeto Jorge Haje, sob a justificativa de que ele definia a constituição de uma rede de ensino profissional paralela ao sistema regular de ensino. No entanto, ao propor a supressão desse artigo, os seus propositores estariam delegando a quem detém o poder econômico a responsabilidade da organização e da gestão do ensino profissional. Dessa maneira, esses educadores não considerariam as necessidades imediatas dos trabalhadores e de milhares de jovens, que necessitam uma alternativa de formação profissional (sendo claro que a formação profissional não é geradora de emprego), através do aprofundamento da discussão “[...] sobre a organização de diferentes modalidades de ensino profissional, entendido como processo de educação permanente articulado ao sistema regular de ensino". (1993, p.34)

O documento apontava também a preocupação em relação aos jovens, com um entendimento muito claro de todo o quadro de precarização caracterizado pela entrada precoce no mercado de trabalho, que inclusive, inviabilizava-lhes tanto o prosseguimento e a 
conclusão de sua escolaridade regular, como oportunidades de preparo profissional. Praticamente, a única alternativa existente de formação profissional para essa faixa etária constituía-se no SENAI, com uma política extremamente seletiva de entrada de alunos, bem como com uma proposta de ensino fortemente demarcada pelo seu caráter ideológico patronal, presente também nos cursos, métodos, conteúdos de ensino, na relação professor/aluno e nas normas disciplinares. Além disso, estava também presente a crítica em relação ao financiamento desta instituição, realizada através de fundo público com gerenciamento empresarial.

Dessa maneira, entre suas considerações o documento vincula a “[...] discussão do ensino profissional/requalificação permanente à luta pelo salário digno, liberdade de organização no local de trabalho e garantia de emprego". (1993, p.36) Recomenda o levantamento dos sindicatos cutistas que ofereciam atividades de formação profissional, como o objetivo de se elaborar um diagnóstico dessas experiências, bem como propor a articulação entre eles e sua relação com escolas profissionais de caráter comunitário, ou vinculadas ao movimento popular; abrir discussão na CUT sobre a questão do fundo público oriundo do recolhimento de $1 \%$ sobre a folha de pagamento e o controle desse fundo pelas instituições empresariais; elaborar uma proposta de formação profissional para o campo, considerando suas especificidades em diferentes aspectos; apresentar propostas de formação profíssional para os trabalhadores do setor informal, e, por fim, reivindica o "direito de todos os trabalhadores à escola básica, pública, gratuita e de qualidade”, recomendando à Central:

[...] desenvolver com os trabalhadores, sindicatos, entidades filiadas e movimentos sociais organizados políticas que respondam às necessidades colocadas pelas dramáticas condições da vida das classes trabalhadoras. [...] defender a organização de diferentes modalidades de ensino profissional em centros públicos ou privados de formação profissional, em entidades comunitárias e sindicais, articuladas ao sistema regular de ensino. (1993, p.38)

Dessa forma, o que se pode observar entre as duas proposições, é que para além da questão da distinção entre público e estatal, é a consideração da real e imediata situação de trabalho das classes trabalhadoras. O primeiro documento se concentra muito mais na questão da educação regular, de formação geral, propondo que haja uma participação direta dos trabalhadores nos órgãos que propõem o ensino profissional, mas sempre com o foco na educação regular. Por outro lado, no segundo documento, há uma visível preocupação em considerar os dados de realidade e a necessidade política de encaminhamento de alternativas a 
isso. Nesse sentido, a relação entre educação e trabalho aparece, no primeiro documento, de maneira ainda pouco explícita, a não ser na reivindicação da garantia do direito à educação pelos trabalhadores; enquanto o segundo documento, além de realizar a discussão no plano conceitual, preocupa-se em considerar a situação concreta de trabalho e a forma como uma política de formação profissional, na perspectiva dos trabalhadores, deve responder aos desafios existentes.

Segundo Sebastião Lopes Neto ${ }^{10}$, co-autor de um dos documentos citados, um dos principais embates ocorrido em 1993 deu-se em relação aos adolescentes e jovens. Havia uma posição majoritária dentro da CUT, defendida pelo primeiro documento, de que não deveria haver formação profissional para adolescentes, pois isso prejudicaria sua educação escolar. Então, esse grupo, defendia a educação pública, unitária, laica e gratuita, bandeira da Constituinte, mas o fazia de forma genérica. Em contrapartida, uma outra posição, expressa no segundo documento, defendia que seria necessária a defesa dos princípios da oferta da educação pública, da educação geral, mas não se poderia impedir a formação profissional dos jovens trabalhadores, justamente porque, por serem trabalhadores, precisariam ser orientados para o trabalho. O diálogo era difícil, porque, segundo ele, as pessoas ligadas à área da Educação não conseguiam considerar, então, essa situação social e real de trabalho dos jovens, milhares de trabalhadores que entravam (e continuam entrando) no mercado de trabalho todos os anos, sem escolaridade básica concluída e qualificação profissional. Essa posição, que era politicamente minoritária, cresceu e se tornou majoritária em 1994, no V Congresso Nacional da CUT - CONCUT. Para Sebastião Neto ${ }^{11}$, o maior embate se constituiu em torno da visão que, em nome da educação pública, gratuita, e laica, isto é, da formação geral, desconsiderava a formação profissional, entendendo-a como modalidade voltada para a sujeição/dominação dos trabalhadores. Segundo ele, a versão publicada do documento “Diretrizes para uma política de formação profissional da CUT", em 1993, já é fruto das negociações realizadas, e apresenta, como resultado, algumas posições de consenso. Para este grupo, era difícil compreender que a formação profissional consistia em um dos poucos canais de inclusão para milhares de jovens, e que ao não se defender uma política pública de formação profissional aos trabalhadores e aos jovens, davam o poder de realizar essa formação ao Sistema S.

\footnotetext{
${ }^{10}$ Entrevista concedida a Júlio França Lima e Ialê Falleiros Braga, na Escola Politécnica de Saúde Joaquim Venâncio/ FIOCRUZ, Rio de Janeiro - RJ, 24 de fevereiro de 2006.

${ }^{11}$ Entrevista concedida a Sandra Torquato Bronzate, 21 de janeiro de 2008
} 
Dentre as deliberações e propostas resultantes do V CONCUT estão: defesa da escola pública e da formação profissional como parte de um sistema regular de ensino; implementação de políticas públicas que promovam o acesso ao mundo do trabalho, como resultado da discussão e propostas da CUT e das diferentes instâncias da sociedade civil; defesa da formulação de políticas públicas de formação profissional, com garantia da participação de trabalhadores; luta pela constituição de Centros Públicos de Formação Profissional, integrados ao sistema nacional de educação, com dotação orçamentária específica, com gestão pública transparente e democrática; vinculação da formação (qualificação e requalificação) profissional aos processos regulares de ensino, articulação da política pública de educação profissional ao sistema pública de emprego, às políticas de desenvolvimento econômico locais, regionais e nacional (garantia de emprego e ampliação de sua oferta) .

Na $7^{\text {a }}$ Plenária da CUT, que tratou do tema Formação Profissional, esse conjunto de discussões reaparece, de forma mais concisa. Além da já citada referência aos Centros Públicos de Formação Profisssional, o documento afirma que:

[...] a formação básica propiciada pela escola regular não exclui a necessidade de oportunidades de uma formação profissional mais específica realizada nos centros públicos ou privados de ensino profissional, por associações sindicais, comunitárias e populares. Por outro lado, sem a garantia da formação de caráter básico, propiciada pela escola pública, gratuita e de qualidade, a formação profissional se tornará simples adestramento. (CUT, 1995, p.22-23)

O documento também amplia e aprofunda a discussão relacionada às questões do trabalho e às questões da educação, não abandonando os pressupostos gerais já apontados, e procurando contribuir na formulação de políticas. Faz críticas à política governamental, que substitui políticas de emprego por ações de formação, deslocando a discussão de seu problema real e construindo uma explicação ideológica da qualificação e da educação como condição da empregabilidade, justificando, dessa maneira, a política da oferta de cursos de curta duração, bem como a dualidade na organização do ensino profissional. A esse respeito, afirma a disposição da Central "de se empenhar na proposição de formas de integração do ensino geral secundário e do ensino profíssional técnico para a constituição de educação integral ou politécnica”. (CUT, 1995, p.23)

Outro ponto importante do documento é a explicitação do que seria o ensino profissional na perspectiva dos trabalhadores: 
[...] a formação profissional que interessa ao trabalhador é aquela que amplia a satisfação das necessidades múltiplas do ser humano.

O ensino profissional não pode ser reduzido a mero adestramento de mãode-obra para o mercado. Na perspectiva da classe trabalhadora, o ensino profissional tem por objetivo contribuir para a formação de trabalhadores tecnicamente competentes e politicamente comprometidos com a luta pela transformação da sociedade. Nesse sentido, a educação orientada para o trabalho é, ao mesmo tempo, educação profissional e educação política. (CUT, 1995, p.22)

Considerando que essas questões foram sendo aprofundadas e consolidadas, a partir das experiências de educação em curso, desenvolvidas por administrações públicas progressistas e por entidades sindicais e do movimento popular, no ano de 2002, após as eleições, ocorreu uma iniciativa no sentido de sinalizar ao novo governo uma proposta de ensino profissional que se colocava em posição crítica à política de educação e ensino profissional vigentes, e em conformidade com as demandas colocadas pela classe trabalhadora. O documento intitulado "A Qualificação Profissional como Política Pública”, conhecido também como "Carta de Santo André”, sistematizou as conclusões do "Seminário Nacional: A Qualificação Profissional como Política Pública", sediado pela Secretaria de Educação e Formação Profissional do município de Santo André. Organizado conjuntamente com a Faculdade de Educação da Universidade de São Paulo e o IIEP - Intercâmbio, Informações, Estudos e Pesquisas, com apoio técnico do Centro Interamericano de Investigação e Documentação sobre Formação Profissional - CINTERFOR-OIT, contou com a participação de um grupo de trabalhadores, gestores de políticas públicas de trabalho e renda, de educação e formação profissional de governos estaduais e municipais, pesquisadores de universidades, e coordenadores de programas de educação e formação profissional vinculados à sociedade civil, trazendo uma série de discussões e propostas oriundas, em grande parte, da acumulação realizada pelos sujeitos sociais.

O documento analisa o quadro educacional e, mais especificamente, do ensino profissional do governo Fernando Henrique Cardoso. Problematiza a natureza das políticas públicas de qualificação e certificação profissional, se atendem ou não às demandas da formação dos trabalhadores. Uma dos problemas colocados diz respeito ao fato de as políticas em questão estarem contribuindo para promover maior hierarquização da força de trabalho, entre os trabalhadores qualificados e os de baixa ou nenhuma qualificação. Critica a relação entre público e privado, chama a atenção para o papel do "terceiro setor" na execução de políticas públicas de educação e formação profissional, e defende a gestão pública dos recursos públicos no desenvolvimento de uma política pública ampla, integrada e 
transparente, entre outras. Aponta, então, pressupostos já anunciados nas discussões da CUT, mas de alguma forma revistos e ampliados, como a necessidade de as políticas públicas de formação profissional superarem o caráter assistencialista e compensatório; a necessidade da integração da formação profissional, nas suas diversas modalidades de ensino formal e informal, ao sistema de educação nacional. Amplia a relação da educação com o trabalho, entendendo a formação profissional como direito, tal como a educação básica devendo estar articulada às políticas de desenvolvimento econômico local, regional e nacional, bem como ao sistema público de emprego, trabalho e renda. Atribui, ainda, grande ênfase na crítica ao Plano Nacional de Formação/PLANFOR- MTE, à dispersão dos cursos de curta duração, isolados, dissociados da educação básica, que não se constituem em plano de formação que permita ao trabalhador construir um percurso formativo, certificado e validado institucional e socialmente. Destaca a diversidade das demandas sociais - trabalhadores empregados, desempregados, em risco de desemprego, precarizados no setor informal, etc -, chamando a atenção para as questões específicas da juventude, de gênero, etnia e portadores de necessidades especiais, diferenças que traduzem grandes desigualdades sociais e merecem atenção na elaboração de políticas de formação profissional, considerando sua situação nas relações de trabalho.

Dentre as recomendações que o Seminário levantou, além daquelas já anunciadas nos documentos das resoluções da CUT, estão a incumbência da União no que toca ao financiamento da educação de jovens e adultos; a necessidade da formação profissional estar articulada com outras políticas de Estado, em especial as que estão voltadas ao desenvolvimento econômico e social do país; definição da política pública de formação profissional como parte do sistema público de emprego, trabalho e renda, com processos formativos operacionalizados pelas diferentes agências formadoras, públicas e privadas; a criação de centros públicos de formação profissional, com dotação orçamentária para as ações formativas; o papel do Estado como planejador, indutor, organizador e gestor das ações, em um processo de construção participativa dos atores sociais e garantia de recursos a fim de não ocasionar a descontinuidade de políticas; a organização de observatórios permanentes de situações de emprego e de formação, com gestão pública, de participação social multipartite, que desenvolvam pesquisas para acompanhar o movimento do emprego no mercado de trabalho, o conteúdo das ocupações e oferta de formação; organização da qualificação profissional em itinerários formativos e a criação de um sistema de certificação profissional, articulado aos Ministérios da Educação e do Trabalho, que, através de um sistema de créditos vinculados aos processos regulares de ensino, reconheçam o percurso realizado através de 
cursos e módulos referentes às especialidades ou ocupações dos diferentes setores da economia, principalmente reconhecidos pelas empresas, nas negociações, convenções e contratos coletivos.

Seria preciso um capítulo à parte neste texto para conseguir abordar a complexidade das questões colocadas pelas resoluções deste seminário, entre elas, a gestão do Sistema S, a não disponibilização, pelas empresas, de recursos públicos para a formação, a gestão e a organização das escolas técnicas, estaduais e federais, e o estabelecimento da educação integrada.

Com relação aos jovens, as recomendações consideram que as políticas de acesso ao trabalho devem coibir formas precoces e precárias de inserção no mercado de trabalho, e garantir o direito à educação básica e à formação profissional, além de alternativas de emprego e geração de renda aos seus pais. Em consonância com as diretrizes gerais pelo Conselho Nacional dos Direitos da Criança e do Adolescente - CONANDA, observa a necessidade de o novo governo integrar as políticas de atendimento aos adolescentes, evitando a sobreposição e a concorrência entre os programas pelos fundos existentes.

É possível observar no percurso aqui colocado, desde as discussões iniciadas em 1992 até o final de 2002, que o tratamento da relação entre educação e trabalho se ampliou em dois sentidos: tanto no que se refere à divulgação e discussão dos temas pertinentes, quanto em termos do desenvolvimento de suas perspectivas e proposições políticas.

Nessa direção, é importante mencionar a experiência do Conselho da Escola de Trabalhadores, antes Conselho de Escolas Operárias, que incorporava experiências de formação profissional organizadas por trabalhadores, realizadas a partir da década de 1970 . Moraes, Pontuschka e Kruppa (2007) descrevem os objetivos do Conselho:

O Conselho de Escolas de Trabalhadores é constituído por um grupo de escolas mantidas por alguns setores das classes trabalhadoras ligados a movimentos populares ou a sindicatos. Com o objetivo de trocar experiências e unificar propostas, discutir metodologias e objetivos, essas escolas criaram, em seu encontro de 1989, no Rio de Janeiro, um Conselho de Educação Operária, que passou a organizar os seminários subseqüentes e a buscar um maior inter-relacionamento, além de trabalhar na criação de uma política de sustentação financeira global para as escolas. O Conselho vem se reunindo, em todos esses anos, e colocando em discussão questões de conteúdos, metodologias, formação política, inovações tecnológicas na indústria e suas conseqüências sobre os trabalhadores. O Conselho das Escolas Operárias participou, em 1994, do processo de criação do Fórum de Formação Profissional, juntamente com sindicatos de trabalhadores de diversos setores, pesquisadores ligados à área da formação profissional, administrações públicas do campo democrático e popular, entre outros participantes. Neste Fórum, com base na sua experiência adquirida nas 
diversas escolas que delem fazem parte, o Conselho apresentou a proposta de se criarem Centros Públicos para Educação de Cidadãos Trabalhadores. Depois disso, outras escolas se juntaram ao Conselho e, nos últimos anos, este passou a se chamar Conselho de Escolas de Trabalhadores. As escolas que vêm participando dos seminários de educação operária são as seguintes: CADTS - Centro de Aprendizagem e Desenvolvimento Técnico-Social localizado em São João de Meriti, Estado do Rio de Janeiro; CAT - Centro de Aperfeiçoamento do Trabalhador - localizado em Betim, Minas Gerais; AST - Ação Social Técnica Escola de Produção Tio Beijo - localizada em Belo Horizonte, Minas Gerais;COPRE - Centro Operário Recreativo Profissionalizante - localizado em Contagem, Minas Gerais; APJ - Aprender Produzir Juntos - localizado em Teófilo Otoni, Minas Gerais; CTC - Centro de Trabalho e Cultura - localizado em Recife, Pernambuco.

De acordo com Sebastião Neto que, nos anos 1980, integrou o Conselho como um dos representantes da Escola Nova Piratininga, as atividades pedagógicas desenvolvidas pelas escolas influenciou de forma significativa as primeiras discussões e formulações sobre educação de adultos trabalhadores e formação profissional. Essa experiência, desenvolvida por entidades do movimento popular e fora do movimento sindical, foi levada, posteriormente, para a CUT. A possibilidade da formação profissional ser realizada por trabalhadores do "chão da fábrica", nos anos 1970, como forma de resistência ao desemprego e à perseguição política, fora do consolidado Sistema $\mathrm{S}$, em um momento histórico de intensa repressão, abriu perspectivas de construção de uma prática de formação, de relação entre teoria e prática, na perspectiva de quem faz o trabalho e não de quem o planeja. Essa oportunidade de os trabalhadores proporem e gerirem os processos formativos a eles dirigidos, poucas vezes ocorrida na história da sociedade brasileira, consiste em exemplo significativo da possibilidade de contribuírem concretamente na formulação das políticas de formação.

Dessa maneira, pelo que foi aqui exposto, a relação entre trabalho e educação se dá no plano do direito à educação (regular e profissional), como acesso ao conhecimento humano sistematizado que, do ponto de vista dos trabalhadores, deve permitir estabelecer um nexo entre os conhecimentos vividos no trabalho e os conhecimentos científicos e de cultura geral, na perspectiva da politecnia.

Por sua vez, uma política que efetivamente proporcione essa condição aos trabalhadores, deve considerar o contexto da divisão social do trabalho e das relações de trabalho, responsáveis pela situação vulnerável dos trabalhadores diante do capital, o que imprime a necessidade premente da articulação das políticas públicas de educação, de trabalho/emprego e desenvolvimento. 
Em continuidade a esse processo, com a perspectiva de debater os desafios relacionados ao desenvolvimento local, um novo Seminário, “A Qualificação Profissional: entre o direito à educação e o mercado de trabalho", foi realizado na cidade de Recife, com o apoio da Secretaria Municipal de Desenvolvimento Econômico. Alguns participantes do seminário de Santo André estiveram presentes, representantes dos diferentes setores que também compuseram o seminário anterior. Este Seminário ocorreu nos primeiros meses do governo de Luiz Inácio Lula da Silva e o tema principal foi a "Integração das Políticas Municipais”. Seu objetivo era realizar um diagnóstico do que já havia mudado e o que permanecia como obstáculo nos primeiros meses do governo. Deste seminário, que contou com a participação de representantes do Ministério da Educação e Ministério do Trabalho, resultou o documento intitulado "Carta do Recife".

Da mesma maneira, como no documento anterior, não será realizada aqui uma análise de todos os tópicos que o compõem, mas a apresentação do que foi resultante das discussões estabelecidas.

As propostas foram divididas em quatro blocos: o que cabe aos municípios, o que cabe às articulações intermunicipais, o que cabe à esfera federal e a todas as esferas. Com relação aos municípios, as propostas estiveram, entre outras questões, em torno da articulação das políticas das diferentes secretarias, com o objetivo de integrar as ações municipais, criando grupos inter secretariais, inclusive com previsão orçamentária para essas ações; criação de canais de participação da sociedade civil; inclusão da dimensão conceitual de trabalho no projeto pedagógico dos sistemas municipais de educação; investimento nas ações que propiciem o desenvolvimento sustentável local. No que toca às articulações intermunicipais, foi proposta a integração de Estados e Municípios a fim de formular políticas integradas, o que incluía a constituição de Comissões Regionais de Emprego, com o objetivo de localizar dificuldades e potencialidades comuns aos municípios e articular políticas conjuntas entre Municípios e Ministérios. As ações propostas para o âmbito federal foram: criação de um fundo público para o desenvolvimento do ensino profissional com gestão compartilhada; constituição de um fórum nacional, com representantes municipais, estaduais e federal, para elaboração, implantação e acompanhamento das políticas integradas, com participação dos Ministérios; formulação e implantação de políticas de desenvolvimento econômico e social, que se pautem na mudança do modelo econômico, no sentido do desenvolvimento local; discussão do Sistema $\mathrm{S}$, de sua gestão à orientação pedagógica, e sugestão aos Ministérios da Educação e do Trabalho para que considerem os diagnósticos locais no trabalho com os municípios. A todas as esferas, além do que já foi apontado, as 
propostas se direcionaram para a criação de dotação orçamentária para a educação de jovens e adultos, com a compreensão de que o investimento em elevação de escolaridade é condição para a cidadania; a constituição de observatórios sobre a situação do trabalho no plano local, regional e nacional, a fim de fundamentar o planejamento e monitoramento de políticas públicas de trabalho, educação e desenvolvimento; o investimento nas ações que visem a economia solidária; estímulo à análise, sistematização e socialização das experiências de interação entre as políticas de trabalho, educação e desenvolvimento, tendo como critério fundamental a inclusão social; incentivo às Universidades no sentido da produção de saber e tecnologia, e a formação de profissionais para atuar nas políticas públicas de trabalho, educação e desenvolvimento.

Nesse documento aparece um elemento que não estava presente, ou não tão presente, nos documentos anteriores: a questão da economia solidária. Este tema não será tratado neste momento do texto, mas é preciso chamar a atenção para o fato de que com o crescente recrudescimento dos postos de trabalho, algumas proposições de políticas de trabalho e renda apostam no trabalho autônomo e solidário como alternativa aos trabalhadores que não encontram possibilidades de reinserção no mercado de trabalho formal. Este é um dos temas que serão retomados na caracterização do Programa Integrado de Qualificação.

Com a eleição do candidato Luiz Inácio Lula da Silva, havia uma expectativa de que todo o quadro descrito anteriormente começasse a se modificar, uma vez que o seu governo, democrático e popular, representava a possibilidade de se estabelecer relações políticas tanto mais democráticas e acessíveis, quanto mais voltadas para a elaboração de projetos sociais que atendam as necessidades da população. Entretanto, como já foi mencionado, os processos políticos, sociais e econômicos ocorrem dentro da lógica da sociedade de classes, de uma determinada divisão social do trabalho e das necessidades do capital. A configuração do poder, nesse cenário, não ocorre sem embates entre a perspectiva do trabalho e a perspectiva do capital. O que a legislação reflete, nesse sentido, diz respeito à correlação de forças presentes em dada disputa. Nesse contexto ocorre, no campo da educação profissional, a revogação do Decreto $n^{0}$ 2.208/97 e a publicação do Decreto $n^{0}$ 5.154/2004.

Como observam Frigotto, Ciavatta e Ramos (2005), o governo Lula vem se constituindo enquanto um bloco heterogêneo, "com alianças cada vez mais conservadoras". Por essa razão é que a disputa que se trava no campo da educação e trabalho reproduz-se nas ações do governo, pois mesmo tendo assumido o compromisso com os educadores progressistas pela revogação do Decreto $n^{\circ} 2.208 / 97$, o governo apresenta contradições na sua condução. 
O centro do debate entre o que representava o Decreto $\mathrm{n}^{\mathrm{o}} 2.208 / 97$ e o que representa o Decreto $n^{\circ} 5.154 / 2004$ está nas lutas pela redemocratização do país desde os anos 1980 . (FRIGOTTO; CIAVATTA; RAMOS, 2005) Nos fóruns criados para debater qual seria a configuração da educação profissional no governo Lula, existiam três posições diferentes. Uma preconizava a revogação do Decreto $\mathrm{n}^{\mathrm{o}} 2.208 / 97$ e a necessidade de se pautar a elaboração da política de Ensino Médio e Educação Profissional, sem recorrer a uma mudança por decreto, pois isso significava a permanência da postura impositiva do governo anterior. Outra posição defendia a manutenção do Decreto $\mathrm{n}^{0}$ 2.208/97. Uma terceira posição reivindicava a revogação do Decreto n ${ }^{\circ}$ 2.208/97 e a promulgação de um novo Decreto.

Ainda um tanto distante do que os setores progressistas de esquerda reivindicam, o embate travado trouxe alguns avanços. Nesse sentido, conforme argumentam Frigotto, Ciavatta e Ramos (2005), o novo Decreto não deve ser visto como uma imposição, mas como uma indicação, como momento de um processo político a ser encaminhado:

O Decreto $\mathrm{n}^{\circ} 5.154$, de 23 de julho de 2004, nesse cenário, surgiu pelo imperativo de revogar o mencionado Decreto ${ }^{\circ}$ 2.208/97. Na verdade, tratase de uma medida de transição a ser amplamente discutida nos Encontros Regionais programados, objetivando construir democraticamente uma Proposta de Anteprojeto de Lei Orgânica que ofereça maior consistência e profundidade aos conteúdos, procedimentos organizativos e práticas pedagógicas em prol da educação profissional e tecnológica. (BRASIL, 2004a, p.2)

Frigotto, Ciavatta e Ramos afirmam que o Decreto não resolveu os embates em questão. Eles ainda estão ocorrendo no processo de implementação das mudanças apontadas:

Em termos ainda somente formais, o Decreto $\mathrm{n}^{\mathrm{o}}$ 5.154/2004 tenta restabelecer as condições jurídicas, políticas e institucionais que se queria assegurar na disputa da LDB na década de 1980. Daqui por diante, dependendo do sentido em que se desenvolva a disputa política e teórica, o "desempate" entre as forças progressistas e conservadoras poderá conduzir para a superação do dualismo na educação brasileira ou consolida-lo definitivamente. $(2005$, p.11)

O novo Decreto também trabalha com a educação profissional dividida em três níveis assim denominados: formação inicial e continuada de trabalhadores (em substituição a educação profissional de nível básico); educação profisssional técnica de nível médio e educação profissional tecnológica de graduação e pós-graduação.

Com relação à formação inicial e continuada de trabalhadores, o Decreto coloca a necessidade de se ofertar esse nível na forma de itinerários formativos, que permitam o 
aproveitamento e articulação dos estudos. Coloca também a necessidade da articulação desses cursos com a Educação de Jovens e Adultos.

No que toca a educação profissional técnica de nível médio, esta deverá se dar de forma articulada com o ensino médio, integrada (na mesma instituição e com a mesma matrícula), concomitante (com matrículas distintas na mesma instituição, em instituições distintas e em instituições distintas mediante convênios de intercomplementaridade). Dessa maneira, retoma-se a idéia, como demonstram Frigotto, Ciavatta e Ramos (2005), da "formação básica unitária e politécnica". Essa condição permite que se retome a defesa de uma educação integrada ou politécnica. Ainda não é a garantia dela, porque demanda uma ampla discussão acerca dos fins e concepção da formação profisssional referenciada pela politecnia. Além disso, é preciso estar claro qual é o projeto de educação integrada que se pretende. Segundo Frigotto, Ciavatta e Ramos (2005, p.15):

O ensino médio integrado é aquele possível e necessário em uma realidade conjunturalmente desfavorável - em que filhos dos trabalhadores precisam obter uma profissão ainda no nível médio, não podendo adiar este projeto para o nível superior de ensino - mas que potencialize mudanças para, superando-se essa conjuntura, constituir-se em uma educação que contenha elementos de uma sociedade justa.

Em relação à educação profissional tecnológica de graduação e pós-graduação o Decreto coloca que os cursos organizar-se-ão de acordo com as diretrizes definidas pelo Conselho Nacional de Educação. Nesse campo estabelece-se a discussão acerca de qual seria o papel dos CEFET'S em relação ao ensino médio técnico, depois de terem se transformado em instituições de ensino superior.

Retomando uma das afirmações presentes no início deste texto, o processo de correlação de forças é contínuo. Nesse sentido, as ações do governo Lula tomadas até aqui, apontam para algumas mudanças no que se refere ao que foi implementado durante a gestão FHC, incorporando algumas reivindicações importantes dos movimentos sociais populares e dos sindicatos, em particular, os da Central Única dos Trabalhadores. Entre eles a aprovação do FUNDEB, que prevê financiamento para a Educação de Jovens e Adultos. Torna-se imprescindível que a discussão e a defesa de projetos que tenham por referência o trabalho na dimensão ontológica, e não apenas na sua dimensão de mercadoria portadora de valor de troca, adquiram força de argumento e pressão política. A defesa da elevação da escolaridade, não como requisitos para a empregabilidade, mas, como afirma Moraes (1999, p.26), como “exigência da ampliação dos direitos de cidadania, como pressuposto à implantação e 
consolidação do processo democrático no país" deve ser uma das marcas desse projeto, assim como a educação politécnica, enquanto um ensino que integre "ciência e cultura, humanismo e tecnologia, visando ao desenvolvimento de todas as potencialidades humanas". (FRIGOTTO; CIAVATTA; RAMOS, 2005, p.10) Esse projeto também não deve prescindir da participação dos trabalhadores em sua formulação. Formas de gestão democrática que de fato viabilizem a participação dos trabalhadores são fundamentais, imprescindíveis para a construção e a viabilização de políticas públicas e projetos educacionais de qualidade, que atendam as necessidades da população.

Os processos, decisões e propostas discutidas, no percurso descrito, traduzem as expectativas e reivindicações que consideram a relação entre educação e trabalho da perspectiva da classe trabalhadora. A escolha dos documentos, analisados ou citados, convergem para uma proposta de ensino profissional que não considera apenas as demandas do mercado de trabalho, mas a afirmação no campo do direito, da articulação de políticas que considerem também as necessidades dos trabalhadores.

Dessa maneira, o Decreto 5154/2004 é um elemento que consolida no campo do direito, a partir de todo o processo de reivindicações consubstanciado nele, as expectativas de diferentes grupos do movimento social e sindical (CUT, Partido dos Trabalhadores, Partido Comunista do Brasil, Pastorais e outros) no que toca a superação da dualidade, a reintegração do ensino médio e técnico, a proposição do itinerário formativo, a conceituação da formação inicial e continuada, e a orientação quanto a articulação deste nível da educação profissional com a educação básica. Esta última fundamental para a existência de programas como o Programa Integrado de Qualificação.

\subsection{O PROGRAMA INTEGRADO DE QUALIFICAÇÃO NO CONTEXTO ATUAL}

Com a finalidade de situar o município de Santo André a partir de suas características econômicas e sociais, foi realizado o levantamento de alguns dados sócioeconômicos. Não é pretensão deste trabalho realizar análise detalhada da realidade existente e do conjunto de suas implicações para o objeto em estudo, mas levantar algumas questões ou preocupações principalmente no que toca ao campo da relação trabalho e educação, isto é, aos aspectos que se relacionam diretamente ao objeto desta pesquisa, ao Programa Integrado de Qualificação. Por se tratar de um programa inserido em uma política pública municipal que visa oportunizar a sua população usuária melhores possibilidades de inserção/reinserção no mercado de trabalho, ou geração de trabalho e renda, além de possibilitar-lhe o retorno e 
conclusão de sua escolaridade, incluindo-o no campo dos direitos civis. Nessa direção, as informações que seguem podem contribuir para a leitura cursos voltados a uma ocupação, dos itinerários formativos propostos, relacionados ao contexto local ou regional.

\subsubsection{Santo André e a região do $\mathrm{ABC}$}

Santo André é um município da região metropolitana de São Paulo que se localiza na região conhecida como $\mathrm{ABC}$, formada pelos municípios de Santo André, São Bernardo do Campo, São Caetano do Sul, Diadema, Mauá, Ribeirão Pires e Rio Grande da Serra. Essa região (particularmente Santo André, São Bernardo do Campo e São Caetano do Sul) no período de industrialização intensa, ocorrido a partir da década de 1950, transformou-se em um dos pólos mais industrializados do país, impulsionado em grade parte pelas indústrias automobilísticas e por sua cadeia produtiva.

Segundo Conceição (2003), por volta da segunda década do século XX, a região do $\mathrm{ABC}$ já contava com algumas manufaturas, conseqüência do período de acumulação da economia cafeeira. A população de partes dessa região, constituída ainda no final do século XIX, a partir da grande imigração subsidiada pelo governo da província para a constituição da força livre de trabalho, era composta por imigrantes, primeiramente italianos e depois austríacos, alemães e poloneses. Além disso, a implantação da ferrovia pela São Paulo Railway Company, em 1867, e o período de substituição de importações ocorrido entre as duas guerras mundiais, criaram as condições de industrialização da região, que já apresentava um crescimento industrial a partir de 1920 por ser "uma extensão natural dos primeiros núcleos industriais da capital paulista (Água Branca, Luz, Brás, Mooca)”. (2003, p.258)

A partir de 1950 a região tornou-se um núcleo industrial:

[...] 1) localizar-se entre o principal mercado consumidor representado pela capital paulista e o porto de Santos; 2) a construção da via Anchieta, inaugurada em 1947, ligando São Paulo, ABC e Santos (anos depois, no início da década de 70, seria construída também a Rodovia dos Imigrantes); 3) a existência da ferrovia já mencionada; 4) a estrutura manufatureira anterior, que forneceu mão-de-obra já com um mínimo de especialização e; 5) disponibilidade de áreas, com baixo preço dos terrenos. (CONCEIÇÃO, 2003, p.260) 
Segundo o Instituto de Pesquisas Tecnológicas ${ }^{12}$, a constituição do parque industrial apresenta a seguinte configuração:

Esse surto de industrialização teve início com a implantação da indústria automobilística na região do ABC, no bojo do Plano de Metas de 1956. Para atender à demanda das montadoras, instalou-se na região a indústria de autopeças, metalurgia, material elétrico, vidros, materiais plásticos e de pneus. Esse conjunto de indústrias conformou um cluster extremamente articulado de indústrias agrupadas numa mesma região em torno de um único negócio. (2001, p.12)

A tabela abaixo mostra a evolução da indústria a partir desse período.

Tabela 1 - Número de Estabelecimentos Industriais na Região do ABC, 1940/1994.

\begin{tabular}{|l|c|c|c|c|c|c|c|c|}
\hline \multicolumn{1}{|c|}{ Municípios } & $\mathbf{1 9 4 0}$ & $\mathbf{1 9 5 0}$ & $\mathbf{1 9 6 0}$ & $\mathbf{1 9 7 0}$ & $\mathbf{1 9 8 0}$ & $\mathbf{1 9 8 5}$ & $\mathbf{1 9 8 8}$ & $\mathbf{1 9 9 4}$ \\
\hline S. André & 376 & 443 & 457 & 781 & 981 & 745 & 970 & 994 \\
\hline $\begin{array}{l}\text { S. Bernardo do } \\
\text { Campo }\end{array}$ & - & 133 & 284 & 589 & 1.099 & 934 & 1.182 & 1.210 \\
\hline S. Caetano do Sul & - & 165 & 262 & 468 & 557 & 470 & 548 & 592 \\
\hline Diadema & - & - & 37 & 198 & 798 & 970 & 1.102 & 1.111 \\
\hline Mauá & - & - & 84 & 110 & 259 & 184 & 256 & 309 \\
\hline Ribeirão Pires & - & - & 112 & 100 & 143 & 136 & 199 & 215 \\
\hline $\begin{array}{l}\text { Rio Grande da } \\
\text { Serra }\end{array}$ & - & - & - & 9 & 26 & 15 & 20 & 19 \\
\hline Total & 376 & 741 & 1.236 & 2.255 & 3.863 & 3.454 & 4.277 & 4.450 \\
\hline
\end{tabular}

Fonte: Emplasa/ DDU/ SIP/ CCA, com base em IBGE - Censo Industrial do Estado de São Paulo.

* Para o ano de 1994, tomou-se como base a RAIS - Ministério do Trabalho (DIEESE, 2005, p.261)

Tabela 2 - Número de estabelecimentos industriais na região do ABC.

\begin{tabular}{|l|c|c|c|c|c|c|c|}
\hline Municípios & $\mathbf{1 9 9 5}$ & $\mathbf{1 9 9 6}$ & $\mathbf{1 9 9 7}$ & $\mathbf{1 9 9 8}$ & $\mathbf{1 9 9 9}$ & $\mathbf{2 0 0 0}$ & $\mathbf{2 0 0 1}$ \\
\hline Santo André & 1.299 & 1.270 & 1.318 & 1.293 & 1.282 & 1.235 & 1.288 \\
\hline São Bernardo & 1.706 & 1.561 & 1.600 & 1.580 & 1.520 & 1.528 & 1.520 \\
\hline São Caetano & 675 & 704 & 694 & 695 & 683 & 683 & 683 \\
\hline Diadema & 1.285 & 1.254 & 1.304 & 1.338 & 1.341 & 1.379 & 1.395 \\
\hline Mauá & 411 & 424 & 453 & 476 & 479 & 467 & 503 \\
\hline Ribeirão Pires & 255 & 245 & 262 & 257 & 243 & 234 & 227 \\
\hline Rio Grande da Serra & 19 & 21 & 24 & 27 & 23 & 29 & 24 \\
\hline
\end{tabular}

Fonte: Relação Anual das Informações Sociais/ RAIS - Ministério do Trabalho. Janeiro de 2003. Disponível em: <www.seade.gov.br>.

${ }^{12}$ Este documento constitui-se em um relatório solicitado ao Instituto de Pesquisas Tecnológicas pela Prefeitura de Santo André. Instituto de Pesquisas Tecnológicas, Relatório técnico $n^{\circ}$ 56870. Proposições para o Desenvolvimento Econômico do Município de Santo André. São Paulo, 2001, ainda não editado. 
A partir de 1950, verifica-se, também, a entrada de um grande número de trabalhadores migrantes. Segundo Conceição, estes, e os imigrantes que já haviam se estabelecido na região, “ajudaram a constituir uma 'cultura industrial' na região". (2003, p.261) Ao tratarem do crescimento industrial e das mudanças sociais que isso causou em uma sociedade antes de característica agrícola, Mello e Novais (1998) afirmam que o movimento migratório para as cidades, na década de 1970, já havia atingido 40\% da população rural e em três décadas (de 1950 ao final da década de 1970) a migração havia atingido 39 milhões de pessoas.

A região do $\mathrm{ABC}$ foi um dos focos desse movimento migratório. $\mathrm{O}$ movimento migratório impulsionado a partir do plano de metas do governo Juscelino Kubitschek e que foi conformando junto com outros fatores a transformação do país, antes de característica agrária para uma sociedade também industrial e urbana, se manteve mesmo depois desse período, motivado pelo poder de atração que as cidades exerciam na expectativa de melhores condições de vida e pelo movimento de expulsão do campo, provocado principalmente pelo processo de mecanização. Como não é objetivo deste capítulo detalhar o movimento migratório ocorrido nas últimas décadas, vale ressaltar aqui a sua importância para a formação da classe operária do ABC. É possível verificar, mesmo sem o aporte de dados precisos sobre esse movimento, que ele continua a existir com outra conformação ou volume de pessoas.

Segundo dados da Coordenadoria de Indicadores Socioeconômicos da Prefeitura de Santo André, no ano de 2000, a porcentagem da população nativa do município era de 48,2\%. Dos segmentos restantes, 19,3\% moram no município há menos de 11 anos; $10,7 \%$ de 11 a 20 anos; $9,0 \%$ de 21 a 30 anos; 6,8\% de 31 a 40 anos; 4,0\% de 41 a 50 anos e 2,0\% há mais de 51 anos. É possível observar que, em 2000, mais da metade da população ainda era formada por pessoas oriundas de outros locais. Seria interessante verificar, entre esses, quantos são advindos de outros estados e quantos são de municípios próximos ou do próprio estado. Como esse não é o objetivo deste capítulo, o importante a destacar é que a cidade de Santo André ainda é um foco de atração na busca de melhores condições de vida, apesar do movimento de reestruturação produtiva ocorrido na região.

Esse é um dos elementos importantes deste capítulo. Com a reestruturação produtiva, há uma tendência a se afirmar que o $\mathrm{ABC}$ está se transformando em uma região de comércio e serviços e passando por um processo de acentuada desindustrialização ou desconcentração industrial. Apesar disso, a indústria ainda se configura como uma força econômica importante para a região. 
Nesse sentido, a fim de caracterizar a cidade atualmente e contextualizá-la na região e em sua relação com a dinâmica do sistema econômico, serão levantados dados e informações que correspondem a três itens principais: o estabelecimento de indústrias na região (já demonstrado), a situação dos empregos, como se conformam o setor do comércio e de serviços e esses elementos em sua relação orgânica. Não será levantado o número de estabelecimentos comerciais e de serviços, uma vez que para ter uma leitura precisa comparando e relacionando essas três áreas, seria necessário levantar conjuntamente a proporção de empregos e contribuição fiscal que cada um gera. Como a proposta é identificar tendencialmente o contexto econômico e de geração de empregos, a observação será realizada a partir dos elementos colocados. Um outro campo abordado relaciona-se com a questão da escolaridade da população e como isso se inter-relaciona com as questões de trabalho.

Ao se observar a tabela que trata dos estabelecimentos industriais, verifica-se que não ocorre uma queda acentuada no número dos mesmos; com algumas oscilações, em alguns municípios esse número é crescente e, em outros, estável. A desconcentração é verificada pelo Valor Adicionado Fiscal (VAF) ${ }^{13}$. Conforme dados do Observatório Econômico da Secretaria de Desenvolvimento e Ação Regional da Prefeitura de Santo André, publicados em seu segundo boletim, as 20 empresas que mais produziram Valor Adicionado Fiscal tiveram sua participação reduzida de 63,03\%, em 1997, para 55,67\%, em 2002. (2003a, p.7) Porém, Rogério Acca coloca que no quadro geral não há perda significativa no que se relaciona à região do ABC. Apesar da queda apontada pelo Observatório Econômico no que tange a Santo André, o autor aponta que:

Os municípios do ABC, a despeito do intenso processo de reestruturação
produtiva levado a cabo pelas empresas da região, como resposta às pressões
competitivas derivadas do contexto macroeconômico dos anos 1990 ,
mantêm praticamente inalterada a sua participação na geração do VAF da
RMSP ( $27,6 \%$ em 1993 e $28 \%$ em 2001). Assim, longe de confirmar as
previsões funestas acerca do futuro da indústria no ABC, os dados do VAF
confirmam uma vocação marcante dos municípios da região para a alocação
de atividades industriais. (2006) Referindo-se ainda à questão do Valor Adicionado Fiscal, é interessante colocar que, ao tratar da região metropolitana da grande São Paulo, como aponta o autor,

\footnotetext{
${ }^{13}$ O Valor Adicionado Fiscal (VAf), calculado pela Secretaria da Fazenda é utilizado como um dos critérios para a definição do Índice de Participação dos Municípios (IPM) na receita do ICMS. É obtido, para cada município, através da diferença entre o valor das saídas e o valor das entradas de mercadorias e dos serviços de transporte e de comunicação prestados no seu território em cada ano civil. (PREFEITURA DE SANTO ANDRÉ, SECRETARIA DE DESENVOLVIMENTO ECONÔMICO E AÇÃO REGIONAL, 2005)
} 
[...] as estratégias neoliberais dos anos 1990 ensejaram um vertiginoso processo de reestruturação produtiva defensiva por parte do setor industrial, o qual se lastreou em intensos processos de terciarização que, por seu turno, resultaram na externalização de atividades antes desenvolvidas no interior das empresas. Dessa forma, a reestruturação produtiva da década de 1990, longe de plasmar uma transição setorial da metrópole em direção aos serviços, reforçou os laços de funcionalidade entre o secundário e o terciário mediante uma industrialização das atividades de serviços, gerando um grau crescente de interpenetração organizacional entre os dois setores, assim como uma forte integração espacial da produção no espaço metropolitano, a qual está na base da formação de um espaço industrial de serviços por natureza híbrido. Portanto, o peso maior dos serviços na composição do valor adicionado deve ser visto com mais cuidado, já que a transferência de atividades industriais - no âmbito dos esquemas de industrialização dos serviços - para o setor terciário nos leva a concluir que parte do valor adicionado produzido por este setor é indissociável da produção manufatureira. (2006)

Ainda se referindo ao quadro da indústria no estado de São Paulo, o Observatório Econômico da Prefeitura de Santo André observa, em 2006, que

A participação do Estado no PIB nacional caiu 3,1 pontos percentuais no período analisado (1999-2003), mostrando a possível ocorrência de um novo arranjo na estrutura produtiva do país, a partir da consolidação de eixos de desenvolvimento externos às regiões que lideram o ciclo anterior de expansão econômica. Quanto à desconcentração produtiva do Grande $\mathrm{ABC}$ para o interior do Estado de São Paulo, é possível constatar que houve uma reversão nesse processo, que agora mostra tendência de estabilidade, já que a participação da região caiu apenas 0,1 ponto percentual entre 1999 e 2003. (2006, p.4)

Outro elemento importante nesse quadro é a questão da alocação dos empregos.

No que toca ao setor do comércio e serviços, é interessante notar o crescimento do número de empregados nesses setores, comparados aos da indústria.

Tabela 3 - Distribuição dos empregados na região do ABC.

\begin{tabular}{|l|l|l|l|l|l|l|l|}
\hline & $\mathbf{1 9 8 9}$ & $\mathbf{1 9 9 0}$ & $\mathbf{1 9 9 1}$ & $\mathbf{1 9 9 2}$ & $\mathbf{1 9 9 3}$ & $\mathbf{1 9 9 5}$ & $\mathbf{1 9 9 9}$ \\
\hline Indústria & $52 \%$ & $51 \%$ & $44 \%$ & $43 \%$ & $35 \%$ & $32 \%$ & $30 \%$ \\
\hline Comércio & $12 \%$ & $13 \%$ & $12 \%$ & $13 \%$ & $21 \%$ & $19 \%$ & $22 \%$ \\
\hline Serviços & $36 \%$ & $36 \%$ & $44 \%$ & $44 \%$ & $44 \%$ & $49 \%$ & $48 \%$ \\
\hline
\end{tabular}

Fonte: Subseção DIEESE/ Sindicato dos Metalúrgicos do ABC, com base nas informações do IMES (DIEESE, 2005, p.94).

Há, proporcionalmente, uma tendência maior na queda dos empregos na indústria e altas crescentes verificadas no setor de serviços, seguido pelo de comércio, o que mostra que 
o setor de serviços é o que tem absorvido maior número de trabalhadores. No entanto, conforme colocado por Acca (2006), não se pode observar o setor de serviços desligado do setor industrial, uma vez que não se trata da substituição de um por outro, mas de uma relação de complementaridade entre ambos.

Com relação à alocação dos empregos, Matteo (2005), em análise publicada pelo Boletim do Observatório Econômico, mostra que

A queda na participação da indústria metropolitana tem pelo menos três raízes. A primeira é a crescente automação dos processos industriais, que ocorre com maior intensidade na RMSP, dado o conteúdo tecnológico de seu parque industrial, necessária para garantir a competitividade das empresas aí localizadas. A conseqüência desse primeiro fundamento é uma clara diminuição na capacidade de geração de novos postos de trabalho, mesmo que houvesse um crescimento da atividade. Uma segunda raiz se encontra na aceleração dos processos de terceirização, iniciados a partir dos anos 80 e acelerados após a abertura comercial dos anos 90 . A indústria (não somente, mas principalmente) está focada na sua atividade principal, contratando serviços especializados de outras empresas, na sua maior parte, do setor de serviços. Assim, a maior parte do valor adicionado e do pessoal ocupado nesse setor está nos segmentos de serviços prestados às empresas (tanto os técnicos como os auxiliares). Uma terceira raiz, a mais profunda, diz respeito às condições macroeconômicas do Brasil. (2005, p.11)

A competitividade internacional faz com que a reestruturação industrial elimine postos de trabalho. Ainda segundo Matteo (2005, p.10), esse movimento da indústria não a faz perder força econômica, mas a redefine:

Observando-se os investimentos anunciados na região, no período de 1995 a 2000 , nota-se que o setor industrial continua sendo o que atrai maior volume de recursos, embora o afluxo de investimento para o setor de serviços venha crescendo progressivamente no Grande ABC. Em 2001, 73\% dos investimentos anunciados na região convergiam para o setor industrial, $23 \%$ para o setor de serviços e o restante para o comercial.

Os investimentos industriais foram direcionados principalmente para a fabricação de produtos químicos, de borracha e plástico, e para o setor automotivo, demonstrando uma tendência de continuidade do atual perfil produtivo da região. Para o ano de 2003, os dados da Fiesp, Pesquisa de Investimentos do Estado de São Paulo, da Fundação Seade, indicam novamente preponderância dos investimentos industriais - nos setores automotivo, mecânico e químico.

A mesma pesquisa revela que a indústria automotiva paulista esteve na liderança dos investimentos no Estado em 1996 e 2003, período em que o setor investiu US\$ 19 bilhões ou 11,6\% do total da indústria de São Paulo. Com esses investimentos, associados ao anúncio da ampliação do Pólo de Capuava, a estrutura industrial do Grande ABC parece acompanhar o soerguimento da indústria nacional, em geral, e da paulista, em particular. 
Essa redefinição do papel da indústria vem deslocando grande parte da mão de obra para o setor de serviços. Pelas informações destacadas acima, a indústria não perde força econômica, mas é incapaz de gerar postos de trabalho na proporção que gerava até a década de 1980.

Diante desse quadro, é importante observar o que ocorre com relação ao setor de serviços. Segundo dados do Observatório Econômico, em 2003 as cidades de Santo André e São Bernardo do Campo correspondiam a $77 \%$ do faturamento desse setor e por $74 \%$ do pessoal ocupado. Destes, $71 \%$ estavam empregados em empresas grandes (com mais de 100 funcionários), 8,8\% em empresas médias (de 50 a 99 funcionários), 17\% em pequenas (10 a 49 funcionários) e 3,2\% em micro empresas (até 9 funcionários).

Os quadros abaixo demonstram como estava a disposição dos postos de trabalho no ABC e em Santo André, no ano de 2001.

Tabela 4 - Distribuição setorial dos postos de trabalho do Grande ABC - 2001.

\begin{tabular}{|l|c|}
\hline \multicolumn{1}{|c|}{ Atividade } & \% \\
\hline Serviços & 37,96 \\
\hline Indústria de transformação & 36,98 \\
\hline Comércio & 14,68 \\
\hline Administração pública & 7,20 \\
\hline Construção civil & 2,61 \\
\hline Serviços Industriais de utilidade pública & 0,54 \\
\hline Agropecuária, extração vegetal, caça e pesca & 0,04 \\
\hline Outros/ ignorado & 0,00 \\
\hline
\end{tabular}

Fonte: RAIS/ CAGED, PREFEITURA DE SANTO ANDRÉ, 2003, p.3.

Tabela 5 - Distribuição setorial dos postos de Santo André - 2001.

\begin{tabular}{|l|c|}
\hline \multicolumn{1}{|c|}{ Atividade } & Em porcentagem \\
\hline Serviços & 44,58 \\
\hline Indústria de transformação & 22,90 \\
\hline Comércio & 21,28 \\
\hline Administração pública & 8,38 \\
\hline Construção civil & 2,55 \\
\hline Serviços Industriais de utilidade pública & 0,28 \\
\hline Agropecuária,extração vegetal, caça e pesca & 0,02 \\
\hline Outros/ignorado & 0,00 \\
\hline
\end{tabular}

Fonte: RAIS/ CAGED, PREFEITURA DE SANTO ANDRÉ, 2003, p.3. 
Ao comparar os dados do ano de 1989 na tabela de Distribuição dos Empregados da região do $\mathrm{ABC}$ com os dados da Distribuição setorial do ano de 2001, verifica-se que os empregos da indústria em 1989 correspondiam a 52\% e em 2001 a 36,98\%; no setor de serviços em 1989 o valor era de 36\% e em 2001 passa a 37,96\%; o comércio representava 12\% em 1989 e em 2001 passa a 14,62\%. Apesar da primeira tabela não mencionar se a fonte de dados utilizada também foi a RAIS/CAGED ${ }^{14}$, se é possível uma comparação das informações, verifica-se que a indústria perdeu mais postos do que os setores de serviços e o de comércio conseguiram gerar. Foram utilizados, neste texto, dados referentes ao emprego formal, o que sugere que, para além do número de desempregados já existentes, nestes levantamentos, o trabalho informal venha crescendo.

Atualmente a população de Santo André, segundo dados de 2005 da Fundação SEADE, corresponde a 669.076 habitantes. A Coordenadoria de Indicadores Socioeconômicos da Secretaria de Orçamento e Planejamento Participativo da Prefeitura de Santo André, utilizando dados de Censo 2000 do IBGE $^{15}$, indicava que dos 649 mil habitantes daquele período, cerca de $48 \%$ encontravam-se no mercado de trabalho, com a seguinte configuração:

\footnotetext{
Um contingente de 313 mil pessoas integrava, portanto, a População Economicamente Ativa (PEA) do município, seja na posição de ocupados, seja como desempregados.

Os ocupados totalizavam 255 mil pessoas. Já o universo de desempregados era composto por 58 mil trabalhadores, configurando uma taxa de desemprego de $19 \%$ da PEA.

Dentre os 255 mil ocupados, cerca de 82 mil (32\% do total) estavam no setor informal. Ou seja, um terço da força de trabalho, residente no município, tem na informalidade sua principal fonte de renda e sobrevivência. (PREFEITURA DE SANTO ANDRE, 2004, p.3)
}

Segundo dados da mesma Secretaria, a distribuição do pessoal ocupado no setor informal, residente em Santo André, por ramo de atividade, estava assim distribuído: 24\% no comércio, $16 \%$ na indústria de transformação, $11 \%$ nos serviços domésticos, $11 \%$ na construção, 9\% em atividades imobiliárias e os demais se dividiam entre outros serviços coletivos, alojamento e alimentação, transporte, educação, saúde e serviços sociais e outros. Este levantamento não apontou, no campo dos serviços, as atividades ligadas à indústria, tratando dos serviços domésticos. A parcela dos serviços ligados à indústria se expressa no campo do trabalho formal, uma vez que $44,58 \%$ dos postos de trabalho formal da cidade, em

\footnotetext{
${ }^{14}$ Relação Anual de Informações Sociais/ Cadastro Geral de Empregados e Desempregados.

${ }^{15}$ IBGE - Instituto Brasileiro de Geografia e Estatística.
} 
2001, estavam alocados no setor de serviços (conforme tabela distribuição setorial dos postos em Santo André). Isso explica porque o pessoal ocupado no setor informal está mais concentrado no comércio. Outro dado que chama a atenção é com relação à construção civil. No que toca ao trabalho formal, este campo é responsável por $2,55 \%$ dos postos de trabalho, enquanto que no trabalho informal corresponde a $11 \%$.

Sobre a situação do emprego formal nas áreas econômicas da cidade, no ano de 2003, segundo informação da Fundação SEADE baseada na RAIS, a participação no total de empregos ocupados no setor de serviços correspondia a 53,84\%; na indústria, a $22,74 \%$; no comércio, a 20,52\%; e, na construção civil, a 2,89\%. Isso mostra que mais da metade dos empregos da cidade localiza-se no setor de serviços. Comparado ao levantamento de 2001, o setor de serviços apresentou, em termos de postos de trabalho, um crescimento de 9,26\%; a indústria, uma redução de $0,16 \%$; e o comércio, uma redução de $0,76 \%$. Os dados mostram que, de 2001 a 2003, o setor de serviços foi o que gerou um aumento importante nos postos de trabalho, sendo que a indústria e o comércio apresentaram ligeira queda.

Relacionando o trabalho informal com o nível de escolaridade, observa-se que a população que está na informalidade apresenta menor índice de escolaridade, quando relacionada à conclusão ou ingresso no ensino médio, comparada à população que está no trabalho formal. Ao se tratar do ensino fundamental incompleto, no setor informal há uma maior concentração de pessoas que não concluíram o primeiro segmento (até 04 anos de estudo) e o segundo segmento (de 05 a 08 anos de estudo), conforme tabela a seguir:

Tabela 6 - Distribuição do pessoal ocupado, segundo a distribuição na ocupação e anos de estudo, em Santo André, em 2000.

\begin{tabular}{|l|c|c|c|c|}
\hline $\begin{array}{c}\text { Pessoal } \\
\text { Ocupado }\end{array}$ & Até 4 anos & $\mathbf{5}$ a 8 anos & 9 anos ou mais & Total \\
\hline Setor informal & $27 \%$ & $32 \%$ & $41 \%$ & $100 \%$ \\
\hline Setor formal & $15 \%$ & $21 \%$ & $64 \%$ & $100 \%$ \\
\hline Total & $19 \%$ & $24 \%$ & $57 \%$ & $100 \%$ \\
\hline
\end{tabular}

Fonte: Microdados da Amostra - Censo 2000/ IBGE; Coordenadoria de Indicadores Socioeconômicos/ SOPP/ PMSA (PREFEITURA DE SANTO ANDRÉ, 2004, p.10).

Com relação à escolaridade, segundo levantamento da Fundação SEADE baseada em dados do Censo Demográfico do IBGE do ano de 2000, 47,96\% da população com mais de 25 anos de idade tinha menos de 08 anos de estudo no município; no Estado, essa taxa era de $55,5 \%$. O número de pessoas de 18 a 24 anos com ensino médio completo era de $51,63 \%$ em Santo André e, $41,88 \%$, no estado. A taxa de analfabetismo da população de 15 anos e mais 
era de $4,45 \%$ na cidade, e a média de anos de estudos da população de 15 a 64 anos era de $7,4 \%$ no estado e, $8,42 \%$, no município.

Segundo levantamento do DIEESE, baseado no IBGE, a média brasileira de anos de estudo para a população com 10 anos ou mais de idade ocupados em 2003, correspondia a $10,3 \%$, para quem não tinha instrução ou tinha menos de 1 ano; $12,3 \%$, para quem tinha de 1 a 3 anos; $28,1 \%$, para os que tinham de 4 a 7 anos; 16,5\%, de 8 a 10 anos, e 32,5\%, para os que tinham 11 anos ou mais. Na região sudeste eram 5,4\% os que tinham menos de 01 ano ou não tinham instrução; 9,2\%, de 01 a 03 anos; 27,5\%, de 04 a 07 anos; 18,0\%, de 8 a 10 anos, e 39,7\%, para os que tinham 11 anos ou mais. A região sudeste, em relação ao Brasil, apresenta menor índice de população ocupada com menos de um ano de instrução. A faixa que apresenta de 08 a 10 anos de estudo ou 11 anos ou mais de estudo também é um pouco maior que a média nacional. (2005, p.83)

A situação do país apresentada pelo documento Síntese dos Indicadores Sociais, organizada pelo IBGE em 2005, aponta que

Em média, $30 \%$ da população adulta ( 25 anos ou mais de idade) eram analfabetos funcionais, mais de $40 \%$ tinham o ensino fundamental incompleto, $9 \%$ haviam concluído só o ensino fundamental, $18 \%$ concluíram o ensino médio e apenas $8 \%$ possuíam ensino superior completo. (IBGE, 2006, p.12)

Dessa maneira, considerando que há um intervalo de tempo de cinco anos, se é possível estabelecer essa relação, para a mesma faixa etária (25 anos ou mais), o percentual da população em Santo André que apresentava o ensino fundamental incompleto em 2000 (47,96\%) era maior que a média do país em 2004 (40\%).

Há uma tendência presente, que também é colocada pelo mesmo documento, que aponta a defasagem escolar no ensino fundamental: "Supondo constantes as taxas de promoção, repetência e evasão, a expectativa de concluintes para a $4^{\mathrm{a}}$ série do ensino fundamental era de cerca de $88 \%$, enquanto para a $8^{\text {a }}$ série era de apenas 54\%.” (IBGE, 2006, p.12)

Em Santo André, conforme informações do DIEESE, observa-se expressiva taxa de evasão no Ensino Fundamental e, em particular, no Médio. No ano de 1998, a evasão no Ensino Fundamental era de 2,97\%, enquanto que no Ensino Médio era de 10,43\%, apesar dessas taxas apresentarem movimento decrescente em relação aos anos anteriores. 
Segundo informação do DIEESE, no ano de 2003, no país, a média de anos de estudo da população total da região sudeste, por sexo, é a mesma: 7,1. Quando se trata da população ocupada, na mesma região, para os homens a média é de 7,7 anos e, para as mulheres, 8,5 anos. (DIEESE, 2005, p.84, tabela 37) Apesar das mulheres ocupadas apresentarem maior número de anos de estudo, o seu rendimento médio, na região metropolitana da grande São Paulo, no ano de 2004, era menor que o dos homens: 1.199 reais para os homens e 792 reais para as mulheres. ${ }^{16}$ (DIEESE, 2005, p.131, tabela 70)

Esses dados nos levam a pensar que se, por um lado, a mulher consegue obter nível de escolaridade superior aos homens, por outro lado, seu rendimento, apesar de sua maior escolaridade, é menor. Além disso, segundo o DIEESE, a taxa de desemprego na região metropolitana de São Paulo no ano de 2004 para os homens era de 16,3\%, enquanto que para as mulheres era de $21,5 \%$.

Com relação ao sustento dos domicílios, na região do ABC em 2002, o maior índice é o de São Caetano com $28,1 \%$ dos domicílios sustentados por mulheres; Santo André tem 23,8\%; Diadema 23,6\% e São Bernardo 22,2\%. Os demais apresentam valores em torno de $21 \%$. Dessa maneira, é possível observar que quase um quarto dos domicílios é sustentado por mulheres em Santo André.

Nesse sentido, é possível concluir que em termos de trabalho, há um desnível significativo entre homens e mulheres, independente da escolaridade maior que possam apresentar, considerando-se o fato de que além de apresentarem maior escolaridade e menor rendimento no trabalho, também estão sujeitas à jornada doméstica e cada vez mais assumem o posto de chefe de família.

Os dados levantados sobre a economia local, sobre o trabalho e a escolaridade da população permitem que se trace um quadro de extrema especialização dos postos de trabalho, por um lado, e de rebaixamento e precarização do trabalho, por outro, devendo ser considerada a composição desse processo em seus diferentes aspectos (como, no caso, a situação das mulheres). Estas informações podem auxiliar no entendimento da relação que o Programa Integrado de Qualificação constrói com a realidade local.

\footnotetext{
${ }^{16} \mathrm{O}$ documento do IBGE apresenta, também, uma interpretação polêmica sobre as diferenças de desempenho entre os sexos, pois desconhece a existência do alto índice de trabalho doméstico realizado pelas meninas: "Essa entrada tardia das mulheres no mercado de trabalho permite, como já foi dito, que elas obtenham uma maior escolaridade. Por outro lado, no caso dos meninos, a alta taxa de atividade influencia em indicadores como atraso e evasão escolar”. (IBGE, 2006, p.6)
} 


\subsubsection{O Departamento de Educação do Trabalhador e o Ensino Profissionalizante}

Com a finalidade de melhor compreender o processo de desenvolvimento do Programa, nos itens que seguem, além da descrição das ações e informações contidas nos documentos oficiais do Departamento de Educação do Trabalhador e de consultas a fontes bibliográficas, foram incluídas as entrevistas realizadas com a equipe da direção do DET, entendidas como pronunciamentos oficiais e institucionais que orientam as ações do Programa. Não só com relação à equipe diretiva, mas também no que toca aos outros participantes, serão preservadas suas identidades. Dessa maneira, as referências à equipe diretiva, composta por três pessoas que ocupam postos de maior ou menor decisão no DET, mas que atuam, em seu conjunto, na definição das resoluções tomadas, serão tratadas aqui como DET1, DET2 e DET3.

É importante considerar a estrutura e a organização do DET, o que permite melhor localizar os entrevistados e o local que ocupam no Programa. O Departamento se constitui pela Direção, diretamente assessorada pelo Observatório da Educação e do Trabalho, seguindo, em hierarquia decrescente, a Assistência de Direção, Gerência Financeira e Gerência de EJA, Coordenações do MOVA, SEJA e Profissionalizante. No caso dos Centros Públicos, a Coordenação do Profisssionalizante atua junto às diretoras e estas junto aos seus núcleos pedagógicos.

É preciso me mencionar, também, que a direção do Departamento é constituída por membros do Partido dos Trabalhadores e do Partido Comunista do Brasil, o que pode imprimir certas particularidades à condução das políticas.

Foi no contexto da "nova" educação profissional, durante a vigência do PLANFOR, que o Departamento de Educação do Trabalhador - DET, no âmbito da Secretaria de Educação e Formação Profissional como passou a ser denominada, a partir de 1997, na Prefeitura de Santo André, iniciou seu trabalho com qualificação profissional. Esta nova denominação da Secretaria pretende expressar a compreensão do governo de que a formação profissional é uma ação que está no campo da educação, entendida como um direito, e, portanto, não a cargo da Secretaria de Desenvolvimento Econômico ou da Assistência Social, como ocorria anteriormente. Nesse sentido, o governo instituído assume o papel de propor uma política diferenciada das precedentes. Esse período (1997-2000 e 2001-2004) correspondeu, respectivamente, à segunda e terceira gestão do Partido dos Trabalhadores no município. A princípio, em 1997, trabalhou apenas com "cursos livres", como eram denominados os cursos de qualificação durante a vigência do PLANFOR, nas unidades dos 
Centros Públicos de Formação Profissional existentes (Tamarutaca, Onze de Junho e Júlio de Grammont), iniciando, a partir de 1998, o projeto da Suplência Profissionalizante, experiência que possibilitou a criação do Programa Integrado de Qualificação. A Suplência Profissionalizante ocorria nas hoje denominadas EMEIEF's ${ }^{17}$, em algumas salas do SEJA que trabalhavam com o primeiro segmento do ensino fundamental. Dos cinco dias de aula, quatro dias eram destinados às matérias da base comum, e um dia às profissionalizantes. Foram ofertados alguns cursos, como eletricidade, manicura, auxiliar administrativo, culinária e pintura residencial. A avaliação realizada em 2001 apontou que, apesar da iniciativa pioneira no município em integrar a educação de jovens e adultos à área de qualificação profissional, ação que contrariava, na época, as diretrizes da educação profissional, algumas dificuldades ocorreram, fazendo com que, em 2002, este projeto tivesse uma outra formatação.

As dificuldades apontadas indicaram que oferecer um curso de qualificação profissional apenas uma vez por semana não era motivador para os alunos e prejudicava o andamento do curso, além do que alguns alunos e professores do SEJA (os professores não participavam das discussões que o ensino profissionalizante propunha como formação) atribuíam ao curso de qualificação um aspecto secundário. Havia dificuldades para estabelecer momentos de planejamento coletivo e, com exceção do curso de elétrica, as aulas eram ministradas nas condições que as EMEIEF's proporcionavam, sem a instalação de oficinas ou laboratórios, uma vez que uma dificuldade sempre presente era a orçamentária. Os cursos de qualificação profissional eram viabilizados através de verbas do FAT $^{18}$, recebidas em determinados períodos do ano, o que comprometia a continuidade da oferta e forçou a utilização de recursos do tesouro municipal para a manutenção dos cursos. A educação de jovens e adultos, como já foi colocado, não recebia recursos federais, e também era mantida com recursos municipais, daí a dificuldade orçamentária que caracteriza os serviços oferecidos pelo DET, uma vez que os recursos que lhe eram destinados também deveriam atender as demandas da educação infantil.

Nesse período, a contratação dos professores que ministravam as aulas da profissionalização era feita diretamente pela Prefeitura. Eram chamados de monitores e um único concurso foi realizado. Em pouco tempo, o procedimento mostrou não ser a melhor forma administrativa de efetuar contratações, uma vez que as necessidades de qualificação se alteravam e os monitores concursados eram qualificados para uma única função, e não poderiam exercer outra, por caracterizar "desvio de função". O exemplo mais significativo foi

\footnotetext{
${ }^{17}$ EMEIEF - Escola Municipal de Educação Infantil e Ensino Fundamental.

${ }^{18}$ Fundo de Amparo do Trabalhador.
} 
o da monitora de datilografia que, em pouco tempo, teve seu curso de qualificação desativado em função da introdução da informática. Passou-se, então, a contratar monitores por seleção pública, o que trouxe o problema de rotatividade do quadro, uma vez que as contratações por seleção não poderiam se prolongar por mais de um ano, e os monitores contratados por uma seleção não poderiam ser recontratados por outra. A solução encontrada pelo Departamento de Educação do Trabalhador, em 2001, foi realizar parcerias com entidades conveniadas, ONG's ou organizações sindicais, que reconhecidamente tivessem experiência no campo da formação profissional e que trabalhassem em uma perspectiva de formação voltada para a elevação das condições sociais dos trabalhadores, e pudessem contribuir com sua experiência e realizar a contratação do quadro dos instrutores, não mais chamados monitores, para a execução dos programas. Isso foi possibilitado pela Lei 8.142 de 22 de dezembro de 2000. Este dispositivo legal autoriza a celebração de convênios de cooperação técnica e financeira entre a Prefeitura de Santo André - através da Secretaria de Cidadania e Ação Social e Secretaria de Educação e Formação Profissional - e organizações não governamentais sem fins lucrativos e de interesse público, para a execução de programas, projetos e serviços pertinentes às suas áreas de atuação, com vistas à inclusão social da população demandatária, e em observância à Lei Orgânica de Assistência, Lei de Diretrizes e Bases da Educação e Estatuto dos Direitos da Criança e do Adolescente. Apesar do termo do convênio incluir a Secretaria de Cidadania e Assistência Social, não há a intenção de que os convênios tenham uma ação assistencial no caso da formação profissional, a redação da lei para as duas Secretarias se deu em virtude da oportunidade legal de resolver algumas demandas que a prefeitura apresentava. O seu Artigo $3^{\circ}$ determina que as despesas decorrentes da execução da lei serão respaldadas pelo Fundo Municipal de Assistência Social, Fundo de Apoio à Educação e de dotações orçamentárias próprias das Secretarias. O Termo de Convênio detalha as formas de execução e de acompanhamento desenvolvidas pelas Secretarias, às quais as entidades estão se conveniando. No que toca ao Termo de Convênio, serão feitos três destaques. No primeiro, em sua Cláusula $3^{\mathrm{a}}$, entre as obrigações do município, cabe ressaltar o item em que consta a assessoria, orientação, fiscalização e participação da implantação e do desenvolvimento do Plano de Trabalho, com indicação de parâmetros e requisitos para as atividades desenvolvidas, elaboradas em parceria com a entidade. O segundo e terceiro destaques, que constam da $4^{\text {a }}$ Cláusula e tratam das obrigações da entidade, apontam dois aspectos principais, dentre os vários que a compõem. O primeiro diz respeito à manutenção de um quadro de pessoal compatível com as especificações descritas no Plano de Trabalho, de 
maneira a dar plenas condições de realização do objeto conveniado. O segundo aspecto trata da prestação de contas. Conforme consta do termo de convênio:

\begin{abstract}
Apresentar trimestralmente, até o quinto dia útil do mês subseqüente, o demonstrativo, mês a mês, da correta aplicação dos recursos financeiros transferidos, compatível com o Plano de Trabalho, devidamente acompanhado de relatório circunstanciado das atividades desenvolvidas no período, bem como, e quando couber, da relação nominal dos atendidos com o número de seus respectivos documentos de identidade; prestar contas, nos moldes das instruções específicas pelo Tribunal de Contas do Estado de São Paulo, até 28 de fevereiro do exercício subseqüente, dos recursos repassados durante o exercício anterior. (SANTO ANDRÉ, 2000)
\end{abstract}

Tais exigências terão importantes desdobramentos no desenvolvimento das ações do DET e, por conseqüência, no desenvolvimento do PIQ.

No primeiro destaque, em que se chama atenção para o papel do município, o que se quer observar é a elaboração de parâmetros e requisitos para as atividades realizadas em parceria com as entidades.

O Capítulo 2 deste texto, que analisa o desenvolvimento do Programa e as representações que os agentes sociais construíram sobre ele, trata da visão dos coordenadores de convênios sobre a parceria com as entidades, cujas propostas, de uma ou outra forma, têm relação com as reivindicações presentes nas deliberações da CUT ou com outros espaços que apontam a necessidade de romper com a dualidade do ensino, bem como construir propostas mais participativas e democráticas de educação e de formação profissional voltadas para o atendimento das demandas dos trabalhadores. Os dois outros itens que foram destacados, dizem respeito respectivamente à "manutenção de um quadro de pessoal compatível com as especificações descritas no Plano de Trabalho, de maneira a dar plenas condições de realização do objeto conveniado", e a questão da prestação de contas, fiscalizada pelo Tribunal de Contas do Estado de São Paulo. O problema da manutenção do quadro de pessoal também será um tema abordado no Capítulo 2, uma vez que, no início do Programa, cada entidade contratava seu pessoal e isso foi se modificando no decorrer dos anos, por uma série de dificuldades principalmente de ordem financeira, o que refletirá na visão que os professores, por exemplo, têm de sua atuação e do Programa. O segundo item, que se relaciona com este, diz respeito aos problemas de prestação de contas enfrentados pelas entidades e pelo DET, uma vez que estando em consonância com a legislação corrente (LDB e o decreto 2.208/97), a utilização das verbas da educação tanto para a formação profissional 
quanto para o PIQ III (referente ao ensino médio) não estariam contemplados. Este problema será retomado no próximo item.

As entidades convidadas à parceria foram, na época, primeiramente o Centro de Educação, Estudos e Pesquisas - CEEP e, em seguida, a Escola Sindical São Paulo da CUT. O CEEP é uma instituição originária da Escola Nova Piratininga, que esteve ativa entre 1979 a 1996, e foi formada por um grupo de trabalhadores militantes da Oposição Sindical Metalúrgica de São Paulo e oriundos dos processos de demissão ocorridos nas lutas operárias, no final da década de 1970, e que iniciaram uma experiência de ensino profissionalizante. Através dos desdobramentos positivos e da prática profissional desenvolvida puderam inaugurar, em 1984, o Núcleo de Ensino Profissional Livre - Nova Piratininga, na zona leste de São Paulo. Com o fechamento da Nova Piratininga, em 1996, por problemas financeiros, o mesmo ideário reuniu um grupo de pessoas que optaram por continuar o trabalho pautado na idéia de uma escola de trabalhadores para trabalhadores, que se opunham à idéia de separar o fazer do pensar e que acreditavam em uma formação para a classe trabalhadora que unisse uma sólida educação básica e geral com a formação técnica. O CEEP é herdeiro desta experiência, e em parceria com a REAP - Reconstrução, Educação, Assessoria e Pesquisa, é fundado em $1^{\circ}$ de maio de 1998. Mantém uma posição crítica ao modelo social, político e econômico excludente e defende ações de justiça social para a classe trabalhadora. Desenvolve, hoje, ações relacionadas à formação profissional, elevação de escolaridade, economia solidária e formação de formadores. Desde seu início esteve vinculado ao Conselho de Escolas de Trabalhadores, trazendo em seus princípios e ações, as orientações dessa entidade.

A Escola Sindical São Paulo iniciou suas atividades em 1993, como demonstram Bastos e Manfredi (1998), após longo processo de discussão sobre a importância de sua criação, onde estavam envolvidas as Secretarias Nacional e Estadual de Formação da CUT, dirigentes, formadores de sindicatos filiados e equipe de formadores do Instituto Cajamar ${ }^{19}$. Desde esse período, vem desenvolvendo ações relativas à formação de formadores, e sua política de formação é oriunda da experiência anterior do Instituto Cajamar. Seu objetivo era o de constituir uma rede própria de formação, não dependente de pessoas ou instituições externas, no sentido de criar um quadro próprio envolvido com as reflexões sobre a formação sindical. Segundo informações institucionais, a partir de 1999, além do trabalho de formação

\footnotetext{
${ }^{19}$ O Istituto Cajamar foi o primeiro instituto de formação popular de caráter nacional. Foi fundado em 1986 sob a presidência de Paulo Freire e tinha como objetivo responder às demandas de formação das organizações dos moviementos populares, do Partido dos Trabalhadores e da CUT.
} 
sindical passa a atuar também no campo das políticas públicas como elaboradora e executora de programas de educação do trabalhador (EJA e Movimento de Alfabetização), qualificação profissional, formação de conselheiros e economia solidária.

Ocorreram outras parcerias pontuais, como o caso da Confederação Nacional dos Metalúrgicos/CUT que utilizou algumas salas para o projeto Integrar, e o Sindicato dos Químicos do $\mathrm{ABC}$, com o Projeto Alquimia. Estas parcerias ocorreram no período anterior a 2001.

A partir de 2001, as entidades conveniadas assumiram, juntamente com a Prefeitura de Santo André, a execução dos programas de formação profissional. Diferente de como está estruturado hoje, onde cada entidade atua em um único Centro Público, nesse período, as duas entidades atuavam nos três Centros Públicos existentes, onde, de acordo com a existência de demanda, cada entidade era chamada para acompanhar determinada turma ou curso. Os Centros Públicos trabalhavam no sentido de oferecer à população de uma dada região uma pluralidade de cursos, o que se modificou a partir de 2003.

Em 2001 foi instituído o Observatório da Educação e do Trabalho, que tinha como orientação levantar oportunidades de trabalho e corresponder a elas oportunidades de formação, o que seria realizado por meio da sistematização das realidades econômicas regionais e da educação profissional. Nessa perspectiva, propunha-se a organização de um Centro Experimental Público de Educação Profissional, cujos objetivos eram a implantação de cursos experimentais com monitoramento, de novos programas e metodologias, organização de seminários com instituições congêneres, e seminários de capacitação e reelaboração das experiências. A idéia era a de que depois desses experimentos testados, ocorresse um processo de disseminação da experiência. A tarefa seguinte seria a avaliação de egressos, que realimentaria todo o processo.

A necessidade da criação de observatórios que acompanhem o movimento do mercado de trabalho também é um item presente nas reivindicações da CUT. Os observatórios têm origem na década de 1980 na Europa. Basicamente, seu papel seria o de instrumentalizar as políticas públicas e corrigi-las. Consiste em importante instrumento de acompanhamento da realidade, a fim de subsidiar as ações da formação profissional com dados e análises, a fim de que as políticas de educação não fiquem a reboque do que indicam os grupos empresariais em termos de formação e de demandas do mercado de trabalho. Em entrevista com DET3, ele define qual é o papel do Observatório da Educação e do Trabalho hoje, a partir de cinco frentes: a) certificação de alunos: organiza a certificação dos alunos a partir dos resultados do Exame Nacional de Certificação de Competências da Educação de Jovens e Adultos - 
ENCCEJA e da Ata de Resultados Finais, entregue pelos Centros Públicos ao final do ano letivo. É de sua responsabilidade o último parecer em relação à certificação dos alunos; b) monitoramento: consiste na organização dos mapas de movimento e dos bancos de consolidação $^{20}$. O Observatório recebe estes dados e os sistematiza, transformando-os em dados estatísticos de aprovação, retenção, evasão e rendimento dos alunos nas diferentes disciplinas que compõe o Programa; c) planejamento: o Observatório apresenta pareceres relacionados ao contexto sócio-econômico, a fim de contribuir com as decisões e correções de rumo necessárias ao planejamento de uma ação, atividade ou programa; d) captação de recursos: elaboração de projetos que serão encaminhados a instituições de fomentos com o objetivo de trazer recursos para a cidade; e) avaliação dos programas: é a essência do trabalho do Observatório, ação que orientará alterações presentes e futuras dos programas, com vistas à efetividade social, inclusive articulado com o desenvolvimento econômico e com a geração de trabalho e renda para a população. A concepção presente, segundo sua definição, é a de que a educação por si só não gera trabalho ou emprego, mas contribui na evolução social e na organização da sociedade.

Em 2001, iniciou-se também o processo de discussão para que a organização da formação profissional fosse oferecida na forma de itinerários formativos. Junto com essa discussão surge uma outra, que tratava da ampliação da Suplência Profissionalizante, com o objetivo de elevar a escolaridade da população usuária dos Centros integrando esse processo aos itinerários formativos das áreas profissionais propostas. Conforme consta de um documento do DET, intitulado "Projeto de implantação de itinerário formativo", do ano de 2001, a proposição era a seguinte:

[...] ressaltamos a importância da revisão dos programas de formação profissional realizados, a ampliação de políticas de emprego e geração, com as quais, as iniciativas no campo da formação profissional possam ser sintonizadas. [...] Estes programas devem ser voltados para jovens e adultos de baixa renda e escolaridade residentes no Município, de modo que esta população tenha uma maior participação social, através da elevação da escolaridade e formação profissional que permita a inserção no mercado de trabalho e/ou o desenvolvimento de atividades que gerem renda, direta ou indiretamente e possa, ainda, estimular a consciência crítica acerca dos seus direitos e deveres, bem como do seu papel enquanto cidadão trabalhador. (PREFEITURA DE SANTO ANDRÉ, 2001)

\footnotetext{
${ }^{20}$ Mapa de movimento é um formulário entregue mensalmente pelos Centros Públicos com informações sobre $\mathrm{n}^{\circ}$ de inscritos, matriculados, evasões e seus motivos, entre outras informações de cada turma. O banco de consolidação é um resumo das informações contidas no mapa de movimento, sistematizando um quadro de cada Centro.
} 
Ao se referir aos itinerários formativos, o mesmo documento coloca:

[...] propomos a organização dos processos formativos com um plano de formação continuada através de módulos seqüenciais progressivos e flexíveis, que abarquem vários níveis de conhecimentos: dos básicos e técnicos gerais de uma área, aos profissionais mais específicos, incluindo-se saberes mais abrangentes, novos conhecimentos e conceitos relevantes da atualidade. [...] Os conteúdos profissionalizantes constituídos por módulos valorizarão $\mathrm{o}$ estágio de conhecimentos acumulados pelos alunos trabalhadores, respeitando o ritmo e o tempo disponível para o aprendizado [...] permitindo aos alunos trabalhadores a construção de seu próprio itinerário formativo, progredindo em termos de capacitação e obtendo a respectiva certificação, com o reconhecimento formal no processo de inserção e promoção ocupacional. (2001)

A idéia até aqui era a de organizar os cursos em módulos que constituíssem um itinerário em uma respectiva área profissional, de modo que a trajetória modular crescente de conhecimentos fosse acompanhada de uma maior escolaridade do aluno, o qual não teria a sua formação limitada somente aos cursos de qualificação e pudesse retomar o seu processo de escolarização. Dessa forma, para cada módulo que se tornava mais complexo, da formação básica à especialização, aumentava também a exigência de escolaridade como pré-requisito para ingresso. Enquanto essas medidas eram implantadas, o Departamento discutia a possibilidade da ampliação da Suplência Profissionalizante, como forma de garantir ao aluno dos cursos de qualificação, a sua formação geral, integrada à escolaridade.

No ano de 2002, o desenho do programa pautado nos itinerários formativos foi oferecido à população. Se, por um lado, essa organização oferecia aos alunos a possibilidade de escolher uma área profissional em que pudessem ampliar seus conhecimentos, evitando que os alunos passassem por diversos cursos, de diversas áreas, sem conseguir se estabelecer profissionalmente em nenhuma, situação bem comum anteriormente, por outro lado, alguns problemas surgiram. O principal deles era a questão da "vaga garantida", ou seja, o aluno, ao iniciar um módulo, queria ter a garantia de poder cursar o módulo seguinte. O problema residia no fato de que alguns não poderiam ser selecionados para o módulo seguinte. Os critérios de seleção pautavam-se (e ainda se pautam) nas condições sócio-econômicas do inscrito, priorizando aqueles que estão em maior vulnerabilidade social. Dessa maneira, alguns alunos que cursavam um módulo não davam continuidade ao módulo seguinte, pois a população que vinha buscar os Centros, a cada abertura de inscrição, podia estar em pior situação do que aqueles que já o estavam cursando. Além disso, muitos que vinham procurar 
os cursos para inscrição não aceitavam não poder cursar determinado módulo por não possuir o pré-requisito da escolaridade, o que gerou muita insatisfação nos alunos.

Até o ano de 2002 os programas existentes no DET eram: a) Programa de Qualificação e Requalificação do Trabalhador - PQRP, dirigido a jovens e adultos maiores de 18 anos, com os objetivos de qualificar e requalificar profissionalmente trabalhadores, visando a inserção/ reinserção no mercado de trabalho ou a geração de renda; contribuir para que desenvolvessem melhores condições de luta pelos seus direitos e para o exercício da cidadania. Este programa estava pautado no desenho dos itinerários formativos. b) Programa de Educação para o Mundo Trabalho - PEMT, voltado aos jovens entre 14 e 17 anos, visando contribuir para que os educandos mudassem sua perspectiva perante a vida e a sua comunidade, estimulando a continuidade de estudos na rede regular e informando as oportunidades de ensino e de mercado de trabalho. c) Suplência Profissionalizante, reformulada em 2002 com algumas modificações de ordem metodológica. Dos cinco dias de aula, três eram utilizados para as disciplinas da base comum e dois para as aulas de profissionalização. Uma outra novidade é que os professores da profissionalização e da base comum dividiam as aulas todo o tempo, a fim de garantir, ou pelo menos tentar, uma relação de interdisciplinaridade capaz de integrar os conhecimentos escolares aos conhecimentos profissionais e vice-versa, resguardando o princípio contido na proposta da formação geral do trabalhador. Esse programa ocorreu, diferentemente do anterior, nos Centros Públicos e não mais nas EMEIEF's, por decisão da Secretaria de Educação. Essa decisão trouxe vantagens e desvantagens, uma vez que nos Centros a oferta era mais restrita. Por outro lado, no Centro, o professor da rede pública municipal podia participar do trabalho de formação continuada oferecida pelo Departamento, aproximando-se mais das questões referentes ao mundo do trabalho, capacitando-se, assim, para melhor entender a proposta do Programa.

No ano de 2003 muitas mudanças ocorreram. A primeira delas foi a especialização dos Centros Públicos por áreas de atuação profissional. Essa medida foi tomada em razão de um melhor gerenciamento do programa. Cada Centro adaptou-se a uma área específica e uma única entidade conveniada atuaria em cada unidade. A partir daí, como instrumento de gestão do Programa, constituiu-se em cada Centro Público um núcleo pedagógico, composto pela diretora da unidade, coordenador da entidade conveniada, o assistente pedagógico da prefeitura, assistente pedagógico da entidade conveniada, e pela professora de apoio administrativo, do quadro do magistério municipal, que tinha como função o auxílio à diretora. Este núcleo pedagógico é o responsável pela gestão da unidade. 
Dessa maneira, o CPFP Onze de Junho (que depois passou a denominar-se Tecnologia da Informação em Software Livre Valdemar Mattei) passou a atuar na área de informática; o CPFP Júlio de Grammont assumiu a área de comércio e serviços; e o CPFP Tamarutaca (que passou a denominar-se Armando Mazzo), na área de construção civil. Neste ano, também houve a entrada de mais duas entidades conveniadas, a AJA - Ação Jovem para Alfabetização, que atuaria somente com o PEMT, e o Centro de Estudos Sociais e Sindicais $1^{\circ}$ de Maio - CES, que trabalharia em um dos Centros na área de construção civil. O CES foi fundado em 1985, por um grupo de sindicalistas ligados à Corrente Sindical Classista, e o objetivo da entidade era a formação sindical voltada para o fortalecimento do sindicalismo classista, e incluía o debate teórico veiculado pela revista da entidade, chamada "Debate Sindical". Sua experiência foi construída na área da formação sindical, e o seu trabalho com formação profissional iniciou-se em Santo André (até onde foi pesquisado, não há registros de outras experiências com formação profissional). O AJA não foi pesquisado, uma vez que ele não atuou no PIQ em nenhum dos Centros Públicos objetos dessa pesquisa.

\subsubsection{A implantação do Programa Integrado de Qualificação}

Dentre as mudanças ocorridas nas políticas educacionais do município, em 2003, a implantação do Programa Integrado de Qualificação foi uma das mais importantes. Concebido a partir da experiência da Suplência Profissionalizante e pautado na experiência do ano anterior com a organização dos itinerários formativos, o Programa integra a elevação de escolaridade com a formação profissional organizada em itinerários.

Os objetivos do Programa eram, então, os seguintes:

OBJETIVO GERAL DO PIQ

Implementar política pública de educação profissional integrada às ações de inclusão social, desenvolvimento econômico e geração de emprego e renda, que promova o aumento da escolaridade e a qualificação profissional de jovens e adultos, contribuindo para sua permanência na escola e, conseqüentemente, para seu encaminhamento ao mundo do trabalho em melhores condições de inserção profissional e social.

OBJETIVOS ESPECÍFICOS

Desenvolver metodologia de educação básica continuada em concomitância ao ensino profissionalizante, prevendo a certificação de ensino fundamental e médio;

Oferecer ensino profissionalizante estruturado em itinerários formativos segundo a ocupação demandada pelos setores econômicos da indústria, 
serviços e comércio, numa organização modular flexibilizada que possibilite saídas e entradas intermediárias com diferentes graus de profissionalização; Contribuir para a redução do desemprego, postergando o ingresso dos jovens no mercado de trabalho através de ações que os mantenham mais tempo na escola e realizando trabalhos de cunho social dentro da sua comunidade. (SANTO ANDRÉ, 2006)

É presente no Programa as diretrizes e orientações oriundas das discussões anteriores sobre ensino profissional, advindas das discussões ocorridas no interior da CUT, bem como de organizações, educadores e pesquisadores ligados à educação e ensino profissional, marcadamente em uma perspectiva que coloca a classe trabalhadora no centro das decisões. A própria Suplência Profissionalizante já partia do pressuposto da educação integral, entendendo que o ensino profissional deve estar integrado à formação básica dos trabalhadores.

Além disso, a concepção de EJA, do direito à educação, traz a idéia da necessidade do respeito a essa modalidade da educação básica, considerando que ela tem uma identidade própria a ser construída.

O Programa Integrado de Qualificação, na sua idéia original, tinha como prioridade os jovens entre 18 e 26 anos de idade. Segundo documento de avaliação do Observatório da Educação e do Trabalho, essa escolha se dá pautada na seguinte avaliação:

O programa visa priorizar as populações mais desfavorecidas e, dentre estas, as mais suscetíveis de entrar no mercado de trabalho precarizado, que são os jovens pouco escolarizados.

A necessidade de se priorizar os jovens com políticas de educação profissional está alicerçada no fato de que eles muitas vezes abandonam os estudos para entrar no mercado de trabalho, seja ele formal ou informal. De acordo com dados da PNAD, cerca de 35\% dos pré-adolescentes (10 a 14 anos) realizam algum tipo de trabalho remunerado e acabam por abandonar a escola. Devido a estas especificidades, alguns autores sugerem que os jovens-adultos sejam os prioritários no atendimento de política públicas voltadas para a qualificação, justamente por representarem as pessoas ocupadas nos segmentos mais dinâmicos do setor produtivo.

Sendo assim, o objetivo do PIQ é retardar ou evitar a entrada do jovem no mercado de trabalho formal prematuramente, bem como no mercado informal, sem os requisitos mínimos. (SANTO ANDRÉ, 2006)

Ao priorizar os jovens, o Programa propondo-se a contribuir para o retardamento de sua entrada no mercado de trabalho, proporcionava-lhes o pagamento de uma bolsa auxílio, justificada através do trabalho social em empresas ou na própria prefeitura, descrito nas ações abaixo, constantes no mesmo documento do Observatório: 
Ação integrada: o envolvimento de várias Secretarias possibilitará o levantamento de demandas em relação aos cursos, de acordo com as características de atendimento do programa, além da integração (de forma multifacetada) entre outros programas em andamento na cidade, o que permitirá que o aluno seja encaminhado para outros programas, como por exemplo, os de geração de trabalho e renda.

Cesta de recursos: esta cesta terá composição baseada no investimento que as Secretarias teriam que fazer para a realização de cursos profissionalizantes e que, ficando a cargo do DET, não haveria necessidade desse gasto, mas serviria para concessão de bolsas aos alunos do PIQ.

Agente Social: os alunos beneficiados pela bolsa educação prestarão serviços sociais voluntários. (SANTO ANDRÉ, 2006)

Dessa maneira, é possível observar que a ação proposta aos jovens caminha na mesma direção do que apontam os documentos tratados em capítulo anterior deste texto, no sentido de propor ações que coíbam sua entrada precoce no mercado de trabalho, situação que, em grande parte, tem lhes impossibilitado tanto o acesso à educação básica, quanto à formação profissional.

Está explícita, também, a idéia da articulação da política pública de educação e ensino profissional (no nível da formação inicial e continuada) às políticas de inclusão social, desenvolvimento econômico e geração de trabalho e renda, na direção das diretrizes sobre formação profissional propostas por movimentos populares, sindical (CUT) e por algumas administrações públicas, já referenciadas no capítulo anterior. Nessa perspectiva, a oferta do ensino profissional não pode estar desvinculada das políticas de emprego, trabalho ou desenvolvimento econômico. A implementação de medidas nessa direção apresenta, do ponto de vista do poder público municipal, algumas especificidades. Quando se fala em geração de empregos, ou políticas voltadas para esse objetivo, o âmbito do poder municipal é bastante restrito, o que tem levado os municípios, na ausência do emprego formal, a buscarem outras saídas por meio de ações emergenciais, freqüentemente de natureza compensatória, como é o do trabalho autônomo ou das iniciativas de economia solidária, a serem posteriormente retomados neste trabalho.

Na concepção dos entrevistados, o Programa é assim apresentado:

[...] o PIQ se desenhou na perspectiva de resgatar um pouco essa juventude, que seria além de oferecer essa escolaridade, oferecer também a oportunidade de fazer um curso profissionalizante, que tivesse identidade com ele, que ele se identificasse com aquela proposta. Então, em vez de fazer uma escola voltada especificamente para a tornearia, Santo André optou por fazer escolas em segmentos mais diversificados, então há a proposta de mais de 50 cursos diferenciados. As pessoas se identificam muito mais com essa proposta, e aí você vê quando se faz uma avaliação, um 
monitoramento, que um curso dessa natureza tem um nível de evasão significativamente inferior ao que tem os mesmos cursos, em nível nacional. (DET1, 1997)

O PIQ é um programa de aumento de escolaridade vinculado com qualificação profissional. [...] O PIQ hoje, a qualificação profissional a gente coloca como o fator que vai propiciar para o trabalhador ou para o adulto o seu emprego. Isso é uma ilusão, a gente sabe que isso vai acabar não ocorrendo. A importância dessa qualificação profissional, dentro desse programa de elevação de escolaridade, é mais na identificação e um facilitador para a aprendizagem. É óbvio que o trabalhador vai ter um instrumento a mais para poder disputar vaga de mercado, criar um serviço, um trabalho. O PIQ hoje é isso, o direcionamento pra continuidade de estudo enquanto direito, utilizando de estratégias para que o trabalhador fique em sala de aula, dê continuidade, esse valor que ele não tem, esse direito que ele não vê como direito. (DET2, 1997)

No que toca aos seus pressupostos, à origem das concepções/princípios que informam o Programa, os entrevistados do Núcleo de Orientação das políticas do DET colocam o seguinte:

[...] primeiramente, uma das grandes dificuldades que a educação teve no Brasil foi conseguir romper com aquela lógica tradicional, que é inerente à lógica do capitalismo, do fazer, do entender e do fazer, do estudar e do trabalhar, essa tradicional dicotomia. A escola sempre foi preparada para que os cursos que eram oferecidos desde o período das artes e dos ofícios, os filhos dos pobres eram preparados para trabalhar e os filhos dos ricos faziam os cursos mais propedêuticos para se bacharelar, direito, medicina, etc; o filho do pobre ia fazer sempre o curso de metalurgia, de artesanato, qualquer coisa que atendesse a essas necessidades do trabalho. Então, essa dicotomia é feita pra justificar a concepção capitalista da história, o entendimento de que as classes sociais, posições tão definidas, devem se manter naqueles parâmetros traçados na concepção capitalista. E o rompimento desse processo, que ainda não se completou, porque ele é recorrente..., sistematicamente a gente vê a propagação da lógica de que deve ter mais cursos profissionalizantes, as pessoas devem se preparar para o mercado de trabalho, é uma retomada daquela lógica anterior de manter essa dicotomia. [...] Na verdade, vamos dizer assim, o PIQ foi uma construção espontânea, aqui em Santo André, mas a gente não pode deixar de referenciar alguns subsídios mais teóricos que a gente conhece, que a gente sabe pela experiência que deu resultado nesse sentido. Um pouco que a gente utilizou para formatar o desenho inicial dessa proposta foi a própria experiência inicial da concepção social da história. A experiência do socialismo, no início, a experiência da revolução soviética. A gente sabe que naquele período grandes educadores como Pistrak, Kaganov, Krupskaia, todas essas pessoas naquela situação da revolução russa, quando o país era eminentemente agrário e até escravagista, e de uma população semianalfabeta, para não dizer completamente analfabeta, esses educadores criaram esse experimento, essa experiência que pudesse agregar, não deslocar, o conhecer do fazer. E por necessidade da própria história, da própria situação do país, eles agregaram esses elementos que foram o ensino propedêutico e o ensino profissionalizante aliado [...] ou seja, eles tinham a 
oportunidade de, na escola, trabalhar, aprender e levar o conhecimento, esse conhecimento que ele adquiriu para comunidades mais distantes, com menos condição de acessar a escola. Então, isso passando por aí da concepção dos educadores do Brasil principalmente o próprio Paulo Freire, Anísio Teixeira, educadores que, em que pese o Anísio Teixeira ter uma formação muito mais voltada para aquela concepção da escola nova, mas de toda sorte era algo revolucionário entendia que as pessoas tinham o direito do trabalho e que o Estado deveria envidar todos os esforços no sentido de propiciar aos seus cidadãos essa oportunidade. Então, isso daí é o que vamos chamar assim a inspiração inicial, mas na verdade essa construção se deu na equipe da Secretaria de Educação, cada um sugerindo, propondo, etc numa construção conjunta, que por ser uma construção conjunta tenho certeza e a gente sente que todas as pessoas entendem e compreendem que participou dessa construção, e como ela foi uma construção democrática, sem sombra de dúvida será muito mais duradoura. (DET1, 1997)

A gente veio pela construção. Em 98, 99 quando eu entrei tinha só os cursos de qualificação profissional e alguns cursos de suplência, que atrelavam a suplência profissionalizante. E aí a gente foi num crescente, batendo, aprofundando, e em 2003, se não me engano, 2003, 2002, frente a tudo aquilo que a gente já queria tentar unir o aumento de escolaridade com essa qualificação, isso se deu, já é uma bandeira que a gente vem construindo há um bom tempo. [...] Teve algumas experiências daquele programa da CNM, o Integrar, mas na realidade as atividades, as coisas foram acontecendo e a gente vendo o que era o facilitador desse processo pro trabalhador. (DET2, 1997)

A primeira fonte, na verdade, ela passa de uma análise ex ante efetuada já na época pelo próprio Observatório, inclusive eu não estava aqui quando foi feita essa análise, esse diagnóstico, onde eles identificam que, se as políticas não estão articuladas, elas não dão conta do mínimo necessário para esse jovem ou adulto ser atendido e inserido no mercado de trabalho. Inclusive o PIQ nasce dando preferência de atendimento ao jovem. Está lá no seu documento principal. Esse é o primeiro ponto, ele se baliza nesse diagnóstico. Segundo, ele também olha, obviamente, para as experiências de políticas públicas francesas, onde você percebe que lá já vem sendo feito e proposto políticas públicas integradas, que algumas deram certo, outras deram errado. Você, ao olhar para algumas experiências no mundo, você percebe o que é possível ser aplicado no nosso país e o que é possível ser aplicado numa área específica. A cidade de Santo André tem uma realidade diferenciada das demais cidades. É uma cidade que trata a política pública geralmente de forma mais coletiva. Embora você apresente os documentos, apresenta as idéias por escrito, ela geralmente é tratada por um coletivo. $\mathrm{O}$ PIQ foi nesse sentido, quer dizer, embora ela tenha sido apresentado por uma equipe técnica inicialmente, isso foi colocado à disposição das pessoas e elas discutiram a sua viabilidade. Inclusive à luz, da legislação do marco institucional existente no país, o que é possível, o que não é possível de perspectiva de médio ou longo prazo desse Programa. Então, basicamente, os referenciais teóricos estão nessas três pontas. O diagnóstico, a análise, ex ante, à luz das políticas internacionais quais são as experiências existentes e o que deu certo e está dando errado e por que. E esse trato mais coletivo. [...] Olha, eu diria que teve um seminário que foi realizado em Recife, que inclusive gerou a "Carta de Recife" que apresentava alguns elementos de política de formação profissional, de certa forma esses elementos foram 
levados daqui de Santo André para esse evento, embora outras regiões e outras secretarias tenham contribuído para isso também. (DET3, 2008)

Todo o processo descrito anteriormente, os embates no campo da formação profissional, do qual inclusive faz parte o Seminário sobre políticas públicas de qualificação, realizado na cidade de Santo André, no final de 2002, com a participação da Prefeitura Municipal na sua organização, não foram citados pelos entrevistados, embora, como se viu, algumas de suas concepções estivessem presentes no Programa. Apenas DET2 refere-se, de forma superficial, ao Programa Integrar, e DET3 cita o Seminário de Recife, mencionando que Santo André teve importante participação na construção das proposições elencadas. Ao mesmo tempo, tece comentários sobre a política pública francesa de formação profissional, que, de certa maneira, referenciou algumas das orientações da CUT, como, por exemplo, a construção dos itinerários formativos. É interessante notar que todos os entrevistados colocam o fato de o Programa ter sido uma construção coletiva, mas apresentam visões distintas sobre as origens dos pressupostos que norteiam sua formulação, apesar de - como se viu - este Programa conter muitas das proposições resultantes das discussões realizadas nos últimos dez anos pela CUT e por outras entidades envolvidas com a formação profissional voltada aos trabalhadores.

Dentre os objetivos do Programa, é interessante chamar a atenção para o primeiro, que propõe a realização da "educação básica continuada em concomitância ao ensino profissionalizante". Na sua implementação, os gestores tiveram a preocupação de não ferir a LDB ou o decreto 2208/97, que não permitia a oferta de ensino profissional integrado à educação básica. O fato é que, em 2003, já tendo o Presidente Luiz Inácio Lula da Silva assumido o governo, este decreto ainda estava em vigor, não existindo, portanto, aparato legal para a sustentação de um curso integrado. Dessa maneira, pode-se afirmar que os cursos eram concomitantes, no que toca à oferta diferenciada da certificação (certificação do curso profissionalizante e certificação do nível escolar). Outro problema consistia na certificação da escolaridade. Como o Programa, tal qual estava organizado, não encontrasse respaldo na legislação para obter autorização oficial, uma vez que essa não apresentava nenhum dispositivo de reconhecimento de educação integrada, era impossível certificar a escolaridade dos alunos. Por esse motivo, até o ano de 2005, a certificação era realizada por uma entidade certificadora externa.

Em 2003, a situação tornou-se crítica. Até essa data, a certificação era possibilitada via Exame Nacional de Certificação de Competências da Educação de Jovens e Adultos - 
ENCCEJA, ao qual todos os alunos deveriam se submeter. Porém, nesse ano, o exame foi suspenso, o que causou extrema preocupação aos alunos e à equipe do Programa. O problema começou a se resolver quando, através da intermediação do IIEP (Intercâmbio, Informações, Estudos e Pesquisas), ONG que atua no acompanhamento das ações de formação e ensino profissional realizadas pelo movimento popular e administrações públicas, em encontros realizados junto à SEMTEC, iniciou um processo de negociação com o CEFET São Paulo (Centro Federal de Educação Tecnológica), a fim de encaminhar a certificação dos alunos neste ano. No início de 2004, ocorreram algumas negociações com o CEFET para firmar um convênio de certificação, mas as negociações não prosseguiram. Com a volta do ENCCEJA, nesse mesmo ano, esta voltou a ser a alternativa para a certificação dos alunos do ensino médio até 2007. Com a organização, pela prefeitura, do Sistema Municipal de Educação, medida que autorizou o Conselho Municipal de Educação de Santo André a legislar sobre sua própria rede, desde que respeitadas as leis federais de educação, em 2005, foi encaminhado a este Conselho o processo que solicitava a autorização de funcionamento do Programa, na modalidade de Educação de Jovens e Adultos para o ensino fundamental. Com o Programa autorizado pelo Conselho, para o ano de 2006, o problema da certificação no ensino médio permanecia e, por isso, continuou-se com a certificação através do ENCCEJA. A autorização para a certificação do PIQ no ensino médio não foi solicitada, pois a educação de nível médio, segundo a LDB, é atribuição do Estado e não do Município e essa situação suscitaria o aparecimento de problemas com o Tribunal de Contas.

No ano de sua implantação, o quadro docente sofre mudanças. Até então, a maior parte dos professores que atuavam nos Centros Públicos eram conveniados, com exceção dos sete monitores de educação profissional, oriundos do único concurso que ocorreu, e das três professoras da rede municipal que atuavam nas salas de Suplência Profissionalizante. A partir da implantação do PIQ, buscou-se trazer da rede municipal professores que possuíssem habilitação nas diferentes áreas do conhecimento, com um duplo objetivo: desonerar o orçamento do Departamento e tentar consolidar o PIQ, agregando a ele o quadro do magistério público municipal. Na época, acreditava-se que, pela possibilidade da interdisciplinaridade e quantidade de horas atividades previstas, cada professor do núcleo comum (como era chamada a base comum, por ser comum a todos os Centros), assumiria grandes áreas do conhecimento: português, inglês, geografia e história; matemática, ciências, física, química e biologia. Houve um processo seletivo interno à rede municipal e os professores candidatos foram informados sobre o Programa e qual seria sua atuação. Os que foram selecionados aceitaram essa condição, uma vez que demonstraram desde o início, 
envolvimento e compromisso com o Programa. Porém, mesmo com a quantidade de horas atividade previstas (variavam de quatro a oito horas semanais por professor, dependendo de sua jornada), essa opção se mostrou ineficaz. Na avaliação realizada ao final do ano e nos acompanhamentos desenvolvidos durante o processo, os professores constataram que algumas áreas foram mais trabalhadas que outras, de acordo com a formação do professor. No caso, o professor que possuía licenciatura em história, ao trabalhar com quatro disciplinas diferentes português, inglês, geografia e história - priorizava em suas aulas a disciplina que lhe era de maior domínio, relegando a um segundo plano aquela que lhe fosse de menor domínio.

Essa modificação no quadro docente, que reuniu professores conveniados e professores do quadro da rede municipal foi bastante interessante, uma vez que se por um lado, os professores conveniados traziam um conjunto de experiências da escola não formal, da educação popular e da militância política ou sindical, por outro lado os professores da rede municipal traziam a experiência institucional, das atribuições específicas do professor. Ambos ganhavam nessa relação, principalmente no que toca ao planejamento e avaliação do trabalho, e nas perspectivas que o trabalho poderia desenvolver.

O Programa seria, então constituído (e ainda o é) de três grupos distintos de professores: aqueles oriundos do quadro do magistério público municipal, responsáveis pelas disciplinas da base comum (língua portuguesa, história, geografia etc); professores contratados pelos convênios para a mesma finalidade (para as vagas que não eram preenchidas pelos professores municipais); e, os professores, denominados instrutores, incumbidos do ensino profissionalizante.

\subsubsection{Proposta pedagógica}

A proposta pedagógica do programa foi construída pela coordenação pedagógica de então e submetida, em primeiro lugar, aos núcleos pedagógicos através de um espaço de formação criado, denominado Fórum Pedagógico, e, depois, encaminhado ao conjunto dos professores do Programa. Os Fóruns Pedagógicos, vistos como espaço de formação pelas equipes diretivas dos Centros, ocorriam mensalmente e reuniam os núcleos pedagógicos de todos os Centros, com o objetivo de discutir as orientações para a educação profissional no município. Com o passar dos anos, sua característica foi se modificando, tornando-se, cada vez mais, um espaço destinado à formação, e, nos anos de 2005 e 2006, deixou de existir em sua configuração inicial que tinha o objetivo de reunir os núcleos dos Centros e discutir as 
orientações e o planejamento dos programas. Em seu lugar, ocorreram algumas reuniões ampliadas de assistentes pedagógicos, diretoras e coordenação do programa, para discutir, em geral, questões pontuais de execução do Programa.

Essa proposta, a maior parte ainda em vigor, pelo menos no plano formal, orienta-se segundo três eixos centrais de trabalho: a autogestão do conhecimento, a qualificação técnica e a perspectiva político-ideológica.

Ao ser debatida, com o conjunto dos professores, estes agregaram, a partir de suas escolas e de encontros gerais, mais alguns objetivos para cada eixo.

O eixo "autogestão do conhecimento" propõe, como uma das principais preocupações do Programa, a apreensão, por parte dos alunos, de instrumentos que lhes propiciem a autonomia na busca do conhecimento e no exercício profissional.

Foi o que apresentou maiores dificuldades na elaboração dos objetivos concretos, os quais ficaram assim definidos:

Propiciar mediações pedagógicas que possibilitem ao aluno:

Desenvolver capacidades de construção do conhecimento dentro e fora do âmbito escolar;

Estimular a pesquisa e procurar novas fontes de conhecimento;

Valorizar a importância dos conhecimentos do núcleo comum como parte da formação integral;

Relacionar entre si as diversas áreas do conhecimento e suas aplicações práticas;

Planejar, desenvolver e gerenciar o seu projeto de vida com autonomia;

O estímulo à reflexão, ao espírito investigativo, no processo de aquisição do conhecimento. (PREFEITURA DE SANTO ANDRÉ, 2003b)

É possível observar que, neste eixo, há a presença de diferentes idéias, advindas de diferentes matrizes. Os seus objetivos referem-se à concepção do "Aprender a Aprender", presente na "nova educação profissional” do governo Fernando Henrique Cardoso, mas é marcado, ao mesmo tempo, não só pelas propostas originárias da participação do coletivo dos professores, da coordenação e dos núcleos pedagógicos, como por outras idéias portadoras de um outro entendimento, que não é exatamente aquele proposto pelo PLANFOR, no sentido da formação para a polivalência e a flexibilidade do trabalhador. A proposta de construção do conhecimento, presente no primeiro objetivo, orienta-se na teoria construtivista, um dos aportes teóricos que fundamentam as ações da Secretaria de Educação e Formação Profissional. Na valorização do Núcleo Comum como parte da formação profissional está presente a idéia de trabalhar, junto com o aluno, a necessidade de sua formação geral, na compreensão de que o conhecimento escolar, além de ser direito, é base para qualquer 
formação, idéia que se contrapunha ao "novo conceito" do PLANFOR. Planejar, desenvolver e gerenciar o seu projeto de vida com autonomia diz respeito a uma idéia corrente na formação profissional do Município desde sua implantação, na qual o ensino profissional tem como objetivo contribuir com o trabalhador em suas escolhas, a partir do conhecimento da realidade. O sentido deste eixo, no entendimento da maior parte do conjunto dos trabalhadores do Programa, referia-se muito mais à construção da autonomia intelectual do trabalhador, a partir da apropriação de saberes das diferentes áreas, incluindo a profissional, no sentido de conhecer a realidade para poder nela atuar, do que as competências para atender às novas necessidades do mercado de trabalho.

O eixo da "qualificação técnica" refere-se aos dois campos, o profissional e o dos conhecimentos gerais. É o ensino de técnicas profissionais e de seu desenvolvimento histórico, no propósito de ampliar esses conhecimentos, associando o aprendizado do técnico operacional aos conhecimentos das diferentes áreas científicas que o fundamentam, de modo a promover um aprendizado mais significativo e global.

Seus objetivos são os seguintes:

\author{
Articular os diversos saberes e fazeres no contexto da realidade do \\ aluno e do mundo do trabalho: \\ Acessar os conteúdos específicos de cada área profissional para o seu \\ crescimento pessoal possibilitando vivencias práticas; \\ Integrar os conhecimentos do núcleo comum e da especificidade \\ profissional na perspectiva da interdisciplinaridade; \\ Estimular discussões criticas sobre ética profissional; \\ Propiciar atualização tecnológica para melhoria contínua de qualidade. \\ (PREFEITURA DE SANTO ANDRÉ, 2003b)
}

Para relacionar o ensino profissional aos conhecimentos das diferentes disciplinas, define-se uma alternativa metodológica que se pauta na interdisciplinaridade. $\mathrm{O}$ terceiro eixo da proposta pedagógica é a "perspectiva político ideológica", que trata da apreensão, por parte dos alunos, dos conceitos fundamentais para a compreensão histórica da sociedade atual e a possibilidade de mudança social, por meio da participação política e social. Foi o eixo mais polêmico, uma vez que na equipe havia representantes de diferentes grupos políticos. Os objetivos definidos foram:

Estimular a vivência dos valores de união, solidariedade e nãodiscriminação:

Estimular a participação ético-político-social transformadora da sociedade: Orientar e propiciar a vivência de aspectos que os levem a conquistar a consciência de classe; 
Possibilitar informações e análises sobre a realidade econômica e social e a possibilidade de superação da mesma. (PREFEITURA DE SANTO ANDRÉ, 2003b)

Uma das discussões mais candentes desse eixo referiu-se à decisão de se explicitar ou não, no documento, a luta pelo socialismo. Ao final, o coletivo optou por não explicitá-la no documento, mas em torná-la presente nas ações cotidianas dos professores, visando favorecer a "conquista da consciência de classe", traduzida como um dos objetivos a ser alcançado. É importante destacar que nem todas as pessoas do grupo estavam envolvidas nessa discussão, embora tenha sido um importante momento de discussão conjunta, uma vez que o grupo tinha composição diversificada e os professores, muitos com história de militância e experiência em movimentos sociais, contribuíram de modo significativo para a manutenção dos objetivos políticos do Programa, perdidos no decorrer dos anos.

\subsubsection{A questão da qualificação}

Um dos pontos chave do programa é a qualificação profissional. É importante considerar, inicialmente, que ele atua no campo da formação inicial e continuada de trabalhadores, e que os documentos oficiais não se referem ao ensino profissional como qualificação, mas como ensino profissionalizante. Não foi averiguado, nas entrevistas, se essa denominação foi utilizada por algum motivo especial, ou se ela está presente nos documentos pelo fato do serviço ter se constituído institucionalmente, em 1997, como "Profissionalizante" e, dessa maneira, mantido a denominação. Do mesmo modo, quando perguntado a DET2 se havia ocorrido um processo de discussão sobre os termos que o DET utilizaria formalmente, o porque de ter sido assumido a denominação "educação profissional", como consta em alguns documentos e folders distribuídos na cidade, seu pronunciamento foi no sentido de que a escolha se deu muito mais em virtude do seu impacto de divulgação do Serviço, do que como resultado de uma escolha conceitual.

O uso da terminologia ensino profissionalizante, no entanto, não dispensa a concepção de qualificação, até por conta de sua designação nos dispositivos legais, sempre destinada aos processos informais de ensino, como é o caso de um dos programas desenvolvidos pelo DET, o "Programa de Qualificação e Requalificação Profissional", do MTE. A idéia da qualificação está presente nos discursos dos entrevistados do DET, com 
variantes na sua concepção. Antes, no entanto, de apresentar suas idéia sobre qualificação, é preciso mencionar, ainda que brevemente, o debate conceitual a respeito desta noção.

Segundo estudos de Tartuce (2004), duas correntes, na França, apresentavam o conceito de qualificação: a "essencialista", baseada nas proposições de Georges Friedmann, e a "relativista", baseada nas concepções de Pierre Naville. A primeira trata a qualificação do ponto de vista da qualidade do trabalho e do tempo de formação necessário para realizá-lo. Através da qualidade e complexidade da tarefa estabelecem-se os atributos necessários ao seu desempenho. A tarefa é determinada pela divisão social do trabalho e relaciona-se à tecnologia utilizada. Dessa maneira, estão presentes as idéias da qualificação do trabalho (conteúdos do trabalho) e da qualificação do trabalhador (o saber e o "saber fazer" para execução do trabalho).

A segunda visão, baseada em Naville, se opõe a essa, na medida em que ao considerar a técnica e o conteúdo do trabalho, apreende-os no contexto de um processo e como produto social resultante tanto da contradição entre capital e trabalho, quanto dos fatores socioculturais que interferem no julgamento que a sociedade realiza ao definir o que é um trabalho qualificado. A qualificação situa-se em um tempo e espaço determinados, não é algo que se define a priori. Não se pode medi-la por sua estreita relação com a realização do trabalho, uma vez que o reconhecimento social da qualificação ultrapassa o limite da técnica e se apresenta, também, em suas formas jurídicas e institucionais. Além disso, a qualificações não são produzidas no sistema educativo, mas no sistema produtivo, onde se realizam e são reconhecidas em termos de remuneração e prestígio social, sendo que a escola representa um momento na constituição dessas qualificações. Dessa maneira, Naville questiona a formulação anterior que define a qualificação pela qualidade do trabalho e tempo de formação que ela demanda.

Há que se considerar também que, em Friedmann, a caracterização da atividade de trabalho está mais vinculada a um posto de trabalho dentro da divisão taylorista. Para Naville, a noção de qualificação, que se constrói nas relações de embate permanente entre capital e trabalho, condicionada por elementos sociais e culturais, modifica -se de acordo não só com as mudanças tecnológicas, mas também com as formas de organização do trabalho.

Nessa perspectiva, é previsível que o conceito da qualificação seja deslocado pelo das competências, a partir dos novos requisitos da produção e da organização do trabalho. Diferentemente da organização taylorista, que exige o preparo para um determinado posto de trabalho ou tarefa, o novo paradigma de organização flexível do trabalho requisita, agora, um novo perfil de trabalhador, portador de "conhecimentos" mais amplos e de uma maior 
predisposição para mobilizar habilidades e atitudes no enfrentamento de problemas. Torna-se necessário, do ponto de vista do mercado, um trabalhador que possua outros atributos, mais adaptáveis às necessidades das novas formas de produzir.

No Brasil, a noção de competência é descrita no Parecer do Conselho Nacional de Educação no 16/99: “entende-se por competência profissional a capacidade de articular, mobilizar e colocar em ação valores, conhecimentos e habilidades necessários para o desempenho eficiente e eficaz de atividades requeridas pela natureza do trabalho". Dessa maneira, o discurso oficial mostra, como já foi apontado neste texto, que apesar de não haver consenso sobre o significado de competência, o que as diferentes interpretações têm em comum é o fato de não considerar a relação social implícita no conceito de qualificação. (MORAES, 2001)

Para Tartuce (2004, p.373), o conceito de qualificação supera a noção de competência, uma vez que:

Um trabalho mais complexo, que demande competências variadas e elevadas, não será necessariamente mais qualificado, pois pode não ter, socialmente, reconhecimento simbólico e/ou financeiro. Dito de outro modo, as competências referem-se aos atributos dos trabalhadores, mas não dão conta de sua valorização efetiva.

Nesse sentido, o conceito de qualificação profissional também abarca a organização do trabalho em bases não tayloristas.

O debate sobre qualificação, como se viu, enfatiza as relações no plano do emprego formal. A questão é como tratar a qualificação dos trabalhadores em uma situação de ausência de emprego.

Ao abordar essa questão, Costa (2006) considera que, diante do quadro de desemprego estrutural, os governos adotaram em seus discursos a expressão políticas de geração de emprego e renda, incluindo a qualificação profissional como elemento dessa política. Segundo a autora, o Plano Nacional de Qualificação implementado pelo governo Luiz Inácio Lula da Silva traz, além do restabelecimento da formação integral do trabalhador, a concepção da política de qualificação como um direito, e uma maior ênfase na integração das políticas públicas. Dessa forma, é praticamente impossível tratar a qualificação profissional frente ao desemprego, sem que haja políticas de geração de emprego e renda.

No entanto, como já mencionado anteriormente, o município tem um limite para suas ações e, a não ser que se articule políticas municipais com políticas federais e estaduais, este problema torna-se de difícil resolução. Assim, é necessário observar que, muitas vezes, as 
políticas municipais de geração de trabalho e renda, por meio das ações de apoio ao empreendedorismo, coletivo ou individual, pode vincular a idéia da qualificação profissional à idéia da empregabilidade, presente nos enunciados do PLANFOR/MTE. Nesse sentido é que se torna necessário vincular-se a políticas de outras esferas governamentais, com vistas não só ao trabalho autônomo, mas também à geração de empregos, através de políticas de crescimento e desenvolvimento econômico.

Tendo como um de seus principais objetivos a inserção ou a reinserção no mercado de trabalho, a maioria dos cursos propostos pelo Programa tende a desenvolver uma formação mais voltada para uma determinada ocupação, no sentido de ela propiciar a inserção no mercado formal, o exercício do serviço autônomo ou do pequeno negócio.

No que se refere às conseqüências da reestruturação produtiva para a cidade, ao quadro de emprego e desemprego gerado, DET3 faz a seguinte colocação:

Quer dizer, o que é a na verdade a terceirização, no que consiste a reestruturação produtiva? Ela consiste na diminuição de custos, tanto do ponto de vista da quantidade de postos de trabalho, ou seja, a produtividade de um trabalhador aumentou de forma muito profunda, quer dizer, se você precisava, pra produzir um determinado produto, de tantas pessoas, você reduziu isso pra um terço. $\mathrm{E}$ as pessoas que foram colocadas pra fora, elas tiveram que inclusive buscar novas ocupações, elas não conseguiram mais buscar emprego na mesma ocupação em que elas estavam trabalhando anteriormente. E isso gerou um tipo de política de formação profissional, algumas encetadas pelo governo estadual, outras pelo governo federal e outras iniciadas e depois continuadas pelos municípios, o que a gente chama de requalificação profissional, que é buscar ou aperfeiçoar essa pessoa, atualizando ela na mesma área em que estava, para ela tentar ainda, no mercado de trabalho, principalmente no espaço friccional do emprego; ou seja, sempre tem uma taxa entre a oferta e a demanda que fica ali, flutuando, com uma série de decorrências, porque as pessoas não estão no lugar correto, estão em cidades diferentes etc, então esses trabalhadores procuraram ocupar esse espaço, com base nessa formação de requalificação profissional. Outras, ao perceberem que não conseguiriam retornar aos seus postos de trabalho, buscaram novos cursos, novos postos. Então, essa é a forma com que se articula um pouco a formação profissional com a reestruturação produtiva. Agora, tendo claro, que a formação profissional não gera postos de trabalho, insisto nisso, e os postos de trabalho que foram perdidos por conta da reestruturação produtiva, pela implantação do plano neoliberal, em especial no $\mathrm{ABC}$, dificilmente eles retornam, até porque caso haja o aumento da produtividade (que requeira trabalhadores de) uma ocupação as empresas tendem a utilizar as novas tecnologias, para ocupar esse espaço. Então, um trabalhador que vá fazer um curso que não considere o conhecimento das novas tecnologias, novas áreas de trabalho, está fadado a ficar excluído do mercado formal de trabalho. Então, é pensando nisso que a formação inicial e continuada se apresenta, principalmente de forma mais candente no PIQ aqui na cidade, buscando fazer com que esse trabalhador, ao mesmo tempo, tenha capacidade de efetuar pesquisa, capacidade de buscar outras alternativas e capacidade de buscar caminhos que leve ele a uma 
emancipação fora dessa exigência do mercado formal de trabalho. Daí a articulação, também, com a Secretaria de Desenvolvimento Econômico e em especial o DGTR ${ }^{21}$, com a nova política econômica popular e solidária, quer dizer, procurando propiciar a esses trabalhadores a possibilidade da formação de cooperativas, empreendimentos populares, e até mesmo um trabalho autônomo mais estruturado, que ele não fique sozinho nessa luta pela sobrevivência. Então, daí a articulação dessa política. Qual é o cenário que a gente verifica? Que esse processo vai continuar se aprofundando, porque faz parte das tratativas de competitividade. Se você não consegue competir com seu produto no mercado internacional e mesmo no mercado nacional, uma vez que a economia está aberta para importados, você corre o risco de falência. $\mathrm{O}$ empreendimento, a empresa falindo, gera mais desemprego. Agora, nós temos claro que emprego direto é uma coisa, traz um rol de benefícios para o trabalhador, inclusive planos de saúde, e uma série de outras, alimentação, transporte, que o trabalhador autônomo não tem. Então quer dizer, compreendendo que dentro do cenário do mercado de trabalho você tem situações diferentes e complexas, você tem que preparar políticas que procurem dar conta dessas situações. Tendo claro que, na verdade você está fazendo uma política com vistas a contribuir com uma possível saída de forma mais efetiva. (2008)

No que se refere às propostas de itinerário formativo, eles eram planejados de maneira a que o itinerário iniciasse no PIQ I (primeiro segmento do ensino fundamental) e continuasse no PIQ II (segundo segmento do ensino fundamental) e PIQ III (ensino médio). Cada uma dessas etapas tinha um ano de duração e, caso o aluno não atingisse os objetivos escolares propostos para cada fase, deveria permanecer no ciclo. Como a certificação era desvinculada, um aluno poderia ser certificado na área profissionalizante e não ser na modalidade escolar correspondente e vice versa. Os itinerários não se encerravam no ensino médio, pois o aluno depois de concluí-lo poderia cursar os módulos ainda não cursados na forma de cursos livres. Um problema que o programa apresentava desde o início e que ainda não tem solução é a impossibilidade dos itinerários serem validados como etapa para os cursos técnicos, uma vez que, apesar de previsto na $\mathrm{LDB}$, esses conhecimentos não são ainda reconhecidos e, por isso, não contam como créditos para a continuidade dos estudos. DET2, quando perguntado sobre a possibilidade de articulação com outras redes, argumenta ser essa uma questão de difícil solução:

Não tem, todas às vezes que a gente vai falar com outras instituições, com o próprio estado, a gente fez esse movimento de conversar com a Paula Souza, com o pessoal, não há vontade política para que isso ocorra. Hoje infelizmente governos diferentes, com perspectivas diferentes, não sentam para poder unir esforços. É triste, mas é realidade. (2007)

\footnotetext{
${ }^{21}$ Departamento de Geração de Trabalho e Renda.
} 
A proposta, definição e planejamento dos cursos são descritas da seguinte maneira:

Como nós detectamos que o mercado de trabalho é muito heterogêneo, nós procuramos atender essa heterogeneidade, lembrando sempre que nosso público alvo são exatamente aquelas pessoas mais carentes, as menos preparadas, nossos critérios para a entrada nos cursos são bastante específicos. São pessoas moradoras da cidade que estão desempregadas, em famílias desestruturadas, ou seja, as piores condições são essas em que se encontram. Dado isso, temos que trazê-los para cursos que contribuam na sua inserção, não no mercado de trabalho precário, mas no mercado de trabalho, que ele inclusive consiga vislumbrar perspectiva para sua vida futura. E como é um trabalho que consideramos recente, nós estamos assim no meio do caminho. Primeiro, tentando ofertar cursos que ajudem ele, de forma efetiva, a ficar um longo, o maior tempo possível, dentro do mercado de trabalho. Nós sabemos que a rotatividade do trabalhador é muito grande em diversas ocupações profissionais. (DET3, 2008)

[...] em primeiro lugar, a gente reafirma que não é o problema da formação profissional que vai gerar emprego, mas a gente também precisa ter um certo cuidado, no que a gente possa oferecer para a comunidade, para a sociedade e, de certa maneira, se não tivermos esse cuidado, nós criaríamos uma falsa expectativa. [...] Nós sabemos que o índice de desemprego por desalento, que foram aquelas pessoas que foram procurar trabalho várias vezes e não encontraram, desistiram de procurar, dentro da composição do índice de desemprego é um dos mais significativos; então, as pessoas perdem a sua perspectiva de vida, já que se sentem completamente incompetentes para buscar um trabalho. Então, o que a gente faz, como normativa fazemos, é de que possamos verificar todas as variáveis que compõem a possibilidade do emprego. Então, qual é o tipo de curso que as pessoas mais buscam? Cabeleireiro? Tem uma pontuação. O que é que as empresas mais buscam? A gente vai nos arquivos da Central de Trabalho e Renda, parceria que a gente tem, e aí vai dizer o que as empresas tem mais buscado nesse tipo de profissional. Qual é a tendência de crescimento do segmento em Santo André, com dados, avaliação? Em Santo André, com o incremento do pólo petroquímico, quase que vai triplicar a demanda por mão-de-obra, num primeiro momento da construção civil e num segundo momento do setor plástico. Então, o que nós pensamos, o que a gente já procura fazer, é direcionar os cursos pra esse segmento que está em tendência de crescimento. Então, a gente verifica o setor da indústria, do comércio e do serviço, vê em quais segmentos há uma tendência de crescimento com aporte de recursos, investimentos etc. Vimos, também, a tendência de consumo de outros tipos de serviço, artesanato, reciclagem, etc, todos esses elementos são elementos que constroem variáveis, que constroem a definição dos cursos que vão ser oferecidos. [...] O Departamento, junto com o Observatório, consulta os segmentos envolvidos, o trabalhador: qual é o curso que o trabalhador quer? Esse. Qual é o trabalhador que a indústria quer? Esse. Qual é a tendência de crescimento do setor? Essa. Então todas essas variáveis conjuntamente constituem a definição que o Departamento prioriza para oferecer cursos. Se o setor plástico vai crescer e o setor de hotelaria vai reduzir, a gente vai priorizar, a partir de agora oferecer cursos do setor plástico e não oferecer o de hotelaria. Então, isso é o que se constitui na definição dos cursos. (DET1, 2007) 
Em 2003, os itinerários apresentados foram os seguintes:

Tabela 7 - Centro Público de Formação Profissional Júlio de Grammont comércio e serviços.

\begin{tabular}{|l|l|l|}
\hline \multicolumn{1}{|c|}{ PIQ I } & \multicolumn{1}{|c|}{ PIQ II } & \multicolumn{1}{c|}{ PIQ III } \\
\hline & $\begin{array}{l}\text { TÉCNICAS DE } \\
\text { EMBELEZAMENTO E } \\
\text { ESTÉTICA I }\end{array}$ & \\
TÉCNICAS DE & $\begin{array}{l}\text { Assistente de cabeleireiro } \\
\text { EMBELEZAMENTO E } \\
\text { ESTÉTICA I }\end{array}$ & $\begin{array}{l}\text { Cabeleireiro } \\
\text { EMBELEZAMENTO E } \\
\text { ESTÉTICA I }\end{array}$ \\
Alongamento de cabelo & $\begin{array}{l}\text { Manicura e pedicuro } \\
\text { Alongamento e Decoração de } \\
\text { unhas }\end{array}$ & $\begin{array}{l}\text { Assistente de esteticista facial } \\
\text { Assistente em podologia }\end{array}$ \\
& $\begin{array}{l}\text { Depilação } \\
\text { Decoração e clareamento de } \\
\text { virilha }\end{array}$ & \\
Maquilagem & HOTELARIA TURISMO E \\
HOTELARIA TURISMO E & LAZER AMBIENTAL II & HOTELARIA TURISMO E \\
LAZER AMBIENTAL I & LAZER AMBIENTAL III \\
Camareira & Recepção em hotelaria & Monitoria de atrativos turísticos \\
Serviços de quarto & Monitoria ambiental & Monitoria de lazer e recreação \\
\hline
\end{tabular}

Fonte: Observatório da Educação e do Trabalho/ DET/ SEFP.

Tabela 8 - Centro Público de Formação Profissional Onze de Junho - informática.

\begin{tabular}{|l|l|l|}
\hline \multicolumn{1}{|c|}{ PIQ I } & \multicolumn{1}{|c|}{ PIQ II } & \multicolumn{1}{c|}{ PIQ III } \\
\hline $\begin{array}{l}\text { INTRODUÇÃO ÀS } \\
\text { TÉCNICAS DE MICRO } \\
\text { INFORMÁTICA }\end{array}$ & $\begin{array}{l}\text { TÉCNICAS DE MICRO } \\
\text { INFORMÁTICA }\end{array}$ & $\begin{array}{l}\text { TÉCNICAS AVANÇADAS DE } \\
\text { MICRO INFORMÁTICA }\end{array}$ \\
$\begin{array}{l}\text { Introdução ao mundo da } \\
\text { informática } \\
\begin{array}{l}\text { Noções de sistema operacional } \\
\text { Sistema operacional e noções de } \\
\text { aplicativos }\end{array}\end{array}$ & $\begin{array}{l}\text { Sistema operacional de multimídia } \\
\text { Aplicativos } \\
\text { Aplicativos avançados }\end{array}$ & $\begin{array}{l}\text { Nécnicas de hardware e software } \\
\text { informática }\end{array}$ \\
\hline
\end{tabular}

Fonte: Observatório da Educação e do Trabalho/ DET/ SEFP. 
Tabela 9 - Centro Público de Formação Profissional Tamarutaca - construção civil.

\begin{tabular}{|c|c|c|}
\hline PIQ I & PIQ II & PIQ III \\
\hline $\begin{array}{l}\text { TÉCNICAS E } \\
\text { PROCEDIMENTOS DA } \\
\text { CONSTRUÇÃO CIVIL NÍVEL } \\
\text { I }\end{array}$ & $\begin{array}{l}\text { TÉCNICAS E } \\
\text { PROCEDIMENTOS DA } \\
\text { CONSTRUÇÃO CIVIL NÍVEL } \\
\text { II }\end{array}$ & $\begin{array}{l}\text { TÉCNICAS E } \\
\text { PROCEDIMENTOS DA } \\
\text { CONSTRUÇÃO CIVIL NÍVEL } \\
\text { III }\end{array}$ \\
\hline $\begin{array}{l}\text { Fundação I } \\
\text { Alvenaria I } \\
\text { Hidráulica I } \\
\text { Elétrica I } \\
\text { Montador I } \\
\text { Acabamento }\end{array}$ & $\begin{array}{l}\text { Fundação II } \\
\text { Alvenaria II } \\
\text { Hidráulica II } \\
\text { Elétrica II } \\
\text { Montador II } \\
\text { Acabamento II }\end{array}$ & $\begin{array}{l}\text { Infra-estrutura } \\
\text { Vigas e Pilares } \\
\text { Alvenaria } \\
\text { Acabamento e instalações } \\
\text { hidráulicas e elétricas } \\
\text { Cobertura } \\
\text { Novas Tecnologias }\end{array}$ \\
\hline $\begin{array}{l}\text { MARCENARIA I } \\
\text { ARTESANAL }\end{array}$ & MARCENARIA II & MARCENARIA III \\
\hline $\begin{array}{l}\text { Técnicas de fabricação de } \\
\text { brinquedos pedagógicos e } \\
\text { objetos em madeira } \\
\text { Técnicas de pinturas e } \\
\text { texturização em madeira }\end{array}$ & Reforma e restauro de móveis & $\begin{array}{l}\text { Fabricação de móveis } \\
\text { (comercial e industrial) }\end{array}$ \\
\hline
\end{tabular}

Fonte: Observatório da Educação e do Trabalho/ DET/ SEFP.

Como pode ser observado, na oferta dos itinerários e cursos, não há formação voltada para o setor industrial. Os cursos oferecidos nas ocupações selecionadas visam o acesso ao emprego formal, mas priorizam os serviços, com perspectivas para o trabalho autônomo.

Na área da construção civil, como já foi apontado, no município de Santo André, o trabalho é responsável por $11 \%$ do mercado informal.

Para poder "oferecer ensino profissionalizante estruturado em itinerários formativos segundo a ocupação demandada pelos setores econômicos da indústria, serviços e comércio", o Departamento instituiu o Observatório da Educação e do Trabalho para desenvolver estudos e levantar as informações necessárias. Ao tratar dessa questão, DET3 afirma:

Nós tentamos implantar o PIQ de forma integral; começamos pelo primeiro eixo, elevação de escolaridade; o segundo eixo, o da formação profissional, e o terceiro eixo, que nós tentamos implantar a partir de sua institucionalização, a partir da Lei do PIQ do ano de 2005. O que nós nos deparamos: os recursos públicos, o nosso grande limitador e o que fez com que essa alteração fosse ocorrendo desde o início do projeto integral e integrado, como estava sendo posto, que fosse alterado ao longo desses anos, com vistas à institucionalização do Programa e com vistas a garantir uma sustentabilidade maior para atender nossos educandos. O Observatório realizou estudos com bases nessas necessidades e nessas alterações, sempre 
apresentou proposição e alternativas que viessem a atender a implantação de forma integral, tal qual ela tinha sido proposta. Agora, as dificuldades foram se deparando, o DET foi tomando as decisões de ajustá-lo, não foi por orientação do Observatório. Ele fazia as ressalvas, olha é por aqui, mas vocês têm esses limitadores, mas apresentava as limitações e cabe sempre ao DET, no seu coletivo, ou, em última instância, na pessoa do diretor, tomar a decisão de continuar mantendo o Programa, quer dizer, perde-se os anéis, mas mantêm-se os dedos para ele continuar funcionando, sempre pensando em ganhar tempo para que lá na frente você consiga retomar ele tal qual estava proposto. Nosso papel é apresentar as limitações e como ele deve ser implementado. Isso sempre foi feito, em documento, em reuniões, em apresentações e mesmo no planejamento. Por exemplo, nós propusemos para o ano de 2005 e 2006 o curso de, que mexeria com calderaria, novos cursos, e o DET se deparou, que não tinha recursos suficientes para bancar máquinas, materiais para poder ofertar esse curso. Nós pressupomos que esses cursos poderiam ajudar melhor a população a se integrar no mercado de trabalho, articulando, por exemplo, a confecção de portões eletrônicos, portões de aço, janelas, articulando isso com a questão da segurança, com chips, fiação eletrônica, vincular alguns produtos com a questão da telecomunicação. Não foi possível por conta de recursos. Quer dizer, os recuos que o DET teve que dar e os ajustes do Programa, como você apresentou aqui, quer dizer o itinerário formativo, ele atendia todas as modalidades a partir, principalmente, do PIQ II final, inicial já articulado à formação profissional e ele teve que recuar, ofertando mais especificamente a área de estética e a área de informática, e, praticamente, só no PIQ III que a gente dá um aprofundamento maior na formação profissional, articulada à elevação de escolaridade. Isso por que se viabiliza dados às parcerias nossas, não com recurso próprio da prefeitura, porque a gente não tem recurso para esse tipo de ação. Então, tudo isso foi ficando muito difícil. (2008)

A intenção é a de articular a oferta de cursos ao desenvolvimento local ou regional. No entanto, o atendimento a essas demandas está condicionado, em primeiro lugar, à questão do financiamento do Programa. A insuficiência de recursos compromete seus objetivos, uma vez que a estrutura necessária para alguns cursos voltados para a indústria ou mesmo a determinadas áreas do setor de serviços demanda alto investimento em equipamentos e oficinas, assim como a necessidade de mantê-la atualizada, do ponto de vista do acompanhamento das mudanças tecnológicas. Este é um problema que afeta, inclusive, as escolas técnicas.

Com relação aos itinerários formativos, uma constatação foi feita nesse ano, já apontada na Suplência Profissionalizante, com relação aos cursos de qualificação. Esses cursos, quando ofertados na forma de cursos livres, apresentam uma dinâmica de aprendizagem diferente de quando ocorrem dentro do PIQ. Nos cursos livres, o aluno aprende mais rapidamente, enquanto que, no PIQ, a aprendizagem é mais lenta. Apresentaram-se duas hipóteses como explicação para isso: o fato de os cursos livres terem aula praticamente todos os dias permite, aos alunos, um encadeamento de idéias e relações 
que os cursos do PIQ, que ocorrem duas vezes por semana, dificultam. Outra hipótese é a de que, no curso livre, como há uma diversidade maior de escolaridade entre os alunos (uma vez que muitos já possuem o ensino médio), as dificuldades de aprendizagem, advindas da ausência de alguns conhecimentos escolares, eram menos aparentes. De qualquer maneira, concluiu-se que as cargas horárias dos cursos de qualificação ofertados pelo PIQ deviam prever essa característica.

Essa era a configuração do PIQ no seu ano de implantação. De 2004 aos dias atuais, muitas modificações ocorreram. Houve problemas em três aspectos: no financiamento do Programa, que comprometeu uma série de ações; na composição do público do Programa: a população que recorria ao PIQ não era formada, na sua grande maioria, por jovens, como se esperava; na não participação de outras Secretarias do governo no desenvolvimento do Programa, que não conseguiu aplicar, a não ser em situações bastante pontuais, o pagamento da bolsa auxílio (e nem foi criada uma linha de financiamento para esse tipo de ação). Um outro problema diz respeito ao fato do Programa não ter um mecanismo efetivo de verificação das informações sócio-econômicas prestadas pelos alunos no ato da inscrição, o que gerou algumas distorções na seleção dos alunos. Alguns alunos omitem informações sobre sua condição sócio-econômica na ocasião da matrícula, a fim de serem selecionados. Isso faz com que, em algumas situações, alunos em melhor situação econômica sejam selecionados em detrimento daqueles que se apresentam em maior risco social. 


\section{CAPÍtULO 2 - DESENVOLVIMENTO E READEQUAÇÕES DO PROGRAMA INTEGRADO DE QUALIFICAÇÃO}

No capítulo anterior analisou-se o Programa, os seus objetivos e pressupostos políticos e pedagógicos. Durante a vigência do PIQ, ocorreram algumas importantes alterações nos seus objetivos e execução, modificando sua intencionalidade inicial.

Neste capítulo, pretende-se verificar como o Programa é concebido pelos seus agentes sociais, como eles apreendem os conceitos presentes no Programa, e como se vêem no papel de atores responsáveis por sua realização. Para isso, serão utilizadas entrevistas desenvolvidas com professores, diretores, assistentes pedagógicos e coordenadores das entidades conveniadas. Os professores receberam nomes fictícios, as diretoras serão tratadas por DIR1, DIR2 e DIR3, os assistentes pedagógicos, por AP1, AP2 e AP3, e os coordenadores, por CORD1, CORD2 e CORD3.

\subsection{AS DIFICULDADES DA GESTÃO}

A principal dificuldade do Programa, como já foi colocado anteriormente, diz respeito ao seu financiamento. Como decorrência da falta de recursos, algumas modificações foram ocorrendo, entre elas, na oferta dos cursos profissionalizantes, na forma de contratação dos professores e na oferta (redução) das turmas de PIQ III. Outras modificações, que afetaram menos estruturalmente o PIQ, dizem respeito à sua gestão pedagógica.

Em 2005, segundo informações extra-oficiais, problemas com o Tribunal de Contas ${ }^{22}$ fizeram com que os cursos livres praticamente deixassem de ser oferecidos. Mantiveram-se aqueles que menos oneravam o orçamento do Departamento. No entanto, promove-se maior oferta de turmas. A princípio, houve uma orientação na elaboração do plano de trabalho, de modo a ficar previsto um número maior de turmas no PIQ II, e menor, no PIQ III. Em 2005, o número de matriculados nas turmas de PIQ II era ligeiramente maior do que nas turmas de PIQ III. Em 2006, no entanto, o número de matriculados no PIQ III superava o PIQ II, conforme mostram os quadros abaixo:

\footnotetext{
${ }^{22}$ O Tribunal de Contas não teria aprovado a prestação de contas da Secretaria de Educação, pois a verba da educação não pode ser utilizada para qualificação profissional.
} 
Tabela 10 - Número de matriculados no PIQ por ciclo em 2005.

\begin{tabular}{|l|c|c|c|}
\hline \multicolumn{1}{|c|}{ CPFP } & PIQ I & PIQ II & PIQ III \\
\hline Valdemar Mattei & 57 & 427 & 338 \\
\hline Júlio de Grammont & 81 & 275 & 221 \\
\hline Armando Mazzo & - & 190 & 128 \\
\hline TOTAL & 138 & 892 & 687 \\
\hline
\end{tabular}

Fonte: Observatório da Educação e do Trabalho/ DET/ SEFP/ PSA.

Tabela 11 - Número de matriculados no PIQ por ciclo em 2006.

\begin{tabular}{|l|c|c|c|}
\hline \multicolumn{1}{|c|}{ CPFP } & PIQ I & PIQ II & PIQ III \\
\hline Valdemar Mattei & 52 & 283 & 332 \\
\hline Júlio de Grammont & 89 & 215 & 250 \\
\hline Armando Mazzo & - & 193 & 211 \\
\hline TOTAL & 141 & 691 & 793 \\
\hline
\end{tabular}

Fonte: Observatório da Educação e do Trabalho/ DET/ SEFP/ PSA.

Esse movimento, que mereceria ser analisado nos anos seguintes para confirmação, ocorreu pelo fato de os alunos do PIQ II darem continuidade aos estudos no PIQ III. De acordo com o depoimento das diretoras do Centros, ocorreu, também, na época, aumento do número de inscrições no PIQ III, em relação ao PIQ II. Dois motivos podem ser levantados para explicar essa situação. O PIQ III apresenta um tempo de duração seis meses menor que o ensino médio, na modalidade EJA, ofertado pelas escolas da rede estadual, e, oferece, de forma diferenciada, uma qualificação profissional integrada à escolaridade. Como não há pesquisa a respeito, levantam-se aqui essas hipóteses. É interessante observar de 2003 a 2006 a evolução geral das matrículas no Programa.

Tabela 12 - Número de matrículas no PIQ de 2003 a 2006.

\begin{tabular}{|l|c|c|c|c|}
\hline \multicolumn{1}{|c|}{ CPFP } & $\mathbf{2 0 0 3}$ & $\mathbf{2 0 0 4}$ & $\mathbf{2 0 0 5}$ & $\mathbf{2 0 0 6}$ \\
\hline Valdemar Mattei & 227 & 321 & 822 & 667 \\
\hline Júlio de Grammont & 194 & 215 & 577 & 554 \\
\hline Armando Mazzo & 43 & 80 & 318 & 404 \\
\hline TOTAL & 464 & 616 & 1717 & 1625 \\
\hline
\end{tabular}

Fonte: Observatório da Educação e do Trabalho/ DET/ SEFP/ PSA.

Há um crescimento no atendimento, que se estabiliza em 2006. De 2003 para 2004, o crescimento é de 32,7\%; de 2004 a 2005, a taxa é de 178,7\%, e, entre 2005 e 2006, a variação é de $-5, .3 \%$ Esses dados indicam o crescimento da adesão da população ao Programa. Não é 
possível precisar os motivos da pequena queda no atendimento em 2006, mas, neste ano, o PIQ II dividiu-se em dois ciclos. Então, se antes os alunos concluíam o segundo segmento do ensino fundamental em um ano, agora passam a fazê-lo em dois. Além disso, como será visto adiante, este foi o ano em que ocorreu uma importante alteração, não exatamente na proposição dos cursos, mas na proposta do itinerário formativo e na possibilidade de cursá-los durante os diferentes ciclos do PIQ. Em 2006, houve também uma redução da carga horária dos cursos profissionalizantes no PIQ II, em virtude da autorização de funcionamento do PIQ pelo Conselho Municipal de Educação. Esta alteração será abordada mais à frente.

Ainda em 2005, a direção do Departamento explicitou às diretoras e aos assistentes pedagógicos dos Centros que, formalmente, o Programa estava pautado em três eixos políticos: elevação de escolaridade, qualificação profissional e trabalho social, eixos que estariam presentes na Lei de criação do PIQ.

Em dezembro de 2005, foi aprovada pela Câmara de Vereadores de Santo André a Lei 8.804, que trata da Criação do Programa Integrado de Qualificação. A importância da aprovação desta lei, para o DET, é a possibilidade de oferecimento da bolsa auxílio através da assinatura, pelo aluno, de um termo de compromisso de atividade sócio ocupacional (trabalho social) e a outorga de bolsa poder se efetivar em parceria com instituições públicas e privadas. Em seu Artigo $2^{\circ}$, especifica os objetivos do Programa:

Art. 2º O Programa Integrado de Qualificação - PIQ tem por objetivo estimular a inserção sócio-econômica, valorizar as vocações ocupacionais, desenvolver a formação integral, a experimentação e a habilitação profissional no local de trabalho, bem como facilitar a reinserção na vida escolar e a continuidade dos estudos de jovens e adultos [...].

O Artigo $6^{\circ}$ trata das diretrizes do Programa:

I -Propiciar o resgate da cidadania dos jovens e adultos de Santo André; II -propiciar aos jovens e adultos ações voltadas à construção de sua autonomia, a formação inicial e continuada de trabalhadores, priorizando as atividades voltadas às ações coletivas e sociais, bem como a sua experimentação nas atividades públicas e privadas, incentivando também as experiências no campo da autogestão, da economia solidária, do cooperativismo e de empreendimentos populares:

III -potencializar a integração do educando em ações voltadas para uma inter-relação em seu local de moradia, possibilitando condições que o tornem referencial para seu grupo social, desenvolvendo atividades de caráter comunitário que melhorem a qualidade de vida e o sentimento de pertencer à comunidade onde reside;

IV -possibilitar alternativas de geração de trabalho e renda, fomentando a movimentação de alternativas de renda nos bairros; 
$\mathbf{V}$-propiciar aos educandos a complementação do ensino e da aprendizagem com programação didático-pedagógica, na linha de formação ocupacional prática, na iniciativa privada, pública ou sob a forma de ação comunitária; VI -viabilizar aos educandos formação técnico-profissional compatível com o seu desenvolvimento integral.

A partir do que foi exposto acima, é possível observar que não está explícita, como prioridade, a formação aos jovens. A lei trata dos jovens e adultos, o que leva a crer que esta diretriz do Programa foi modificada. No entanto, pelo fato de não ter sido realizado o levantamento das matrículas por faixa etária, uma vez que esses dados só foram conseguidos de forma parcial e dispersa, não se tem esta informação. Por outro lado, é de conhecimento público que, apesar do número de jovens vir aumentando em relação às matrículas, o número de maiores de 26 anos ainda supera o número de matrículas na faixa dos 18 aos 26.

Tabela 13 - Inscritos por sexo e faixa etária na área da construção civil em 2003.

\begin{tabular}{|l|c|c|c|c|c|}
\hline & $\mathbf{1 8}$ a 26 & $\mathbf{2 7}$ a 35 & $\mathbf{3 6}$ a 40 & $\mathbf{4 1}$ a 50 & $\mathbf{5 1}$ a 60 \\
\hline Homens & 18 & 18 & 06 & 11 & 03 \\
\hline Mulheres & 04 & 01 & 03 & 01 & 00 \\
\hline Total & 22 & 19 & 09 & 12 & 03 \\
\hline
\end{tabular}

Fonte: Observatório da Educação e do Trabalho DET/ SEFP/ PSA.

Dos 65 inscritos, 33,8\% correspondem à faixa etária prioritária do Programa, e $66,2 \%$ estão acima dessa faixa.

A lei é clara no que toca ao desenvolvimento do terceiro eixo do Programa, a bolsa via monitoria. Como na proposição anterior, a intenção de angariar verbas por meio de uma cesta de recursos propiciada por ação entre Secretarias não se viabilizou; a intenção agora é abrir essa possibilidade à iniciativa privada. O que ocorre é que esta oferta de "experimentação e habilitação profissional no local de trabalho" pode ocorrer em ocupação diferente daquela para a qual o aluno está se formando. Para contornar essa dificuldade, o PIQ deveria oferecer formação profissional em uma área, ligada a várias ocupações. De acordo com DET3,

[...] o terceiro eixo pode trabalhar com a iniciativa privada, com regras claras para não substituir trabalhadores, e também para ele não ser explorado e nem tampouco trabalhar em área insalubres; pode atuar na área das organizações sociais civis, as OSCIP's, as ONG's, prestando serviços ou até mesmo em políticas públicas, como a prevenção na saúde, agente de saúde, ou manutenção de equipamentos etc. Todo esse leque foi elaborado e proposto por escrito ao DET, inclusive vinculado às áreas da $\mathrm{CBO} / \mathrm{Classificação}$ 
Brasileira de Ocupações. Nos balizamos nisso inclusive para apresentar em que áreas esses jovens ou esses adultos poderiam exercitar esse processo de aprendizagem prática a partir do terceiro eixo do PIQ. [...] Você pega um setor, a área dele está vinculada a esse setor, porque nós consideramos hoje, [...] que os cursos que podem propiciar uma viabilidade da entrada do jovem ou adulto no trabalho, são aquelas que consigam transitar em um maior número de ocupações possíveis. Posso citar por exemplo um engenheiro que pode atuar em várias áreas, pode atuar na área que um economista atua, pode ser um professor, pode ser um ajudante, pode ser na área de logística, quer dizer, a profissão de engenheiro pode atuar em qualquer área, praticamente. Ele (o aluno) precisa, obviamente,se especializar em alguns momentos, para determinada área. Então nós pensamos que alguns cursos, nas áreas técnicas, eles teriam que ter essa capacidade de transitar por diversas áreas ou diversas ocupações profissionais, para que o trabalhador ou o jovem, quando tiver sendo formado por esses cursos, ele não fique preso numa armadilha de um determinado cenário que foi apresentado em determinado momento da vida dele. (DET3, 2008)

O que merece ser destacado, neste trecho, é a existência do risco de se pensar a formação para a polivalência, na perspectiva do modelo da competência. É sabido também que a noção de competência, pautada na flexibilização do trabalho e na polivalência do trabalhador, refere-se às alterações na organização do trabalho, o que exigiria trabalhadores com maiores "conhecimentos". O risco da noção de competência está em que ela se refere ao sujeito, e não ao posto de trabalho. Oliveira (2006, p.15) observa isso ao tratar da diferença entre o conceito de qualificação e a noção de competência:

Enquanto a noção de qualificação surgiu referenciada no paradigma fordista de produção, a noção de competência derivou da sua crise e substituição por um novo paradigma, o da produção flexível. No primeiro caso, demandavase do trabalhador a capacidade de cumprir o que lhe fora prescrito, donde a qualificação exigida é parte da prescrição atribuída a cada posto de trabalho - havia, aqui, um realce social-coletivo e objetivo. No segundo caso, a demanda do sistema produtivo para o trabalhador passou a concentrar-se na capacidade deste em colaborar criativa e comprometidamente com a empresa no seu desafio de enfrentar eficientemente a crescente competitividade do mercado - o realce passou a ser mais presentemente no aspecto individual e subjetivo-motivacional. Em um contexto de crescente instabilidade das relações de emprego, ao trabalhador coloca-se, cada vez mais, a exigência de uma qualificação mais ampla, mais versátil e mais continuada, de modo a garantir melhores oportunidades de inserção em um mercado de trabalho mais exigente, mais restrito e submetido a uma dinâmica de mutações cada vez mais acelerada.

Um aspecto a se destacar é que ainda se convive com diferentes formas de organização do trabalho, daquelas caracterizadas pela produção fordista àquelas que se pautam pelas novas tecnologias e automação. Além disso, como colocado anteriormente, o conceito de qualificação se refere a uma relação construída na relação entre capital e trabalho 
e na validação que a sociedade faz dessa qualificação. Dessa maneira, a qualificação é sempre baseada na relação entre o trabalhador e as mediações necessárias para a realização de seu trabalho, e não apenas nos atributos pessoais que possa vir a ter.

Nesse sentido, a colocação de DET3 pode estar pautada pela visão dos arcos ocupacionais. O arco ocupacional é entendido como:

Um conjunto de ocupações relacionadas, dotadas de base técnica comum, que podem abranger as esferas da produção, da circulação de bens e da prestação de serviços, garantindo uma formação mais ampla e aumentando as possibilidades de inserção ocupacional do/a trabalhador/a (assalariamento, auto-emprego e economia solidária). (BRASIL, 2005)

É preciso estar atento à perspectiva de formação que se pretende. É necessário que os cursos e a formação pretendidos pelo Programa dêem conta da articulação com o mercado de trabalho, mas a qualidade da formação não pode se limitar a esse aspecto, realizando seus objetivos de ensino integrado de conhecimentos relativos à ciência, à técnica e à cultura. $\mathrm{O}$ problema está em se superar o plano das intenções e implementar efetivamente uma proposta de ensino que não reproduza a dissociação, existente no ensino regular, entre ciência e técnica, entre cultura e trabalho.

O desafio, então, é pensar uma formação, uma oferta de cursos que dê conta do contexto atual, sem cair na armadilha das competências, da formação "polivalente". Como pensar um ensino que propicie a articulação entre teoria e prática, a apropriação das bases estruturais de conhecimentos gerais e profissional, que permita uma compreensão crítica do trabalho e de sua realização na sociedade capitalista, para além do limite do "saber fazer" e do "saber ser"?

Quando inqueridos nessa direção, a respeito do entendimento e da incorporação da noção de competência no Programa, tanto DET1 quanto DET2 afirmaram que essa discussão nunca foi aprofundada e que o PIQ não a assume ${ }^{23}$.

Em 2006, duas mudanças importantes ocorreram. A qualificação profissional passou a ser ofertada somente no PIQ III. A justificativa do Departamento de Educação do Trabalhador foi a de que no PIQ II era necessário trabalhar com a questão da tecnologia e inclusão digital em todas as unidades, a fim de que os alunos se apropriassem desse conhecimento que é fundamental para o mundo do trabalho e para a vida pessoal. Sem discutir o mérito dessa orientação, o que vale perceber é que o que pauta essa decisão já foi

\footnotetext{
${ }^{23}$ A forma como o Programa se dispõe a integrar o ensino profissional e as diferentes áreas do conhecimento, estará desenvolvida posteriormente, no item que trata da proposta pedagógica.
} 
colocado por DET3 em entrevista citada neste texto, em que aponta o fato do DET ter realizado adaptações, nem sempre na direção dos objetivos do Programa, mas a fim de mantêlo, diante das dificuldades de sua gestão financeira.

Com relação à oferta dos cursos profissionalizantes somente no PIQ III, isso causou uma séria preocupação nas equipes dos Centros Públicos, uma vez que isto rompia com a idéia do itinerário formativo. Dessa maneira, os alunos dos PIQ's I e II estariam tendo acesso à informática em substituição aos cursos profissionalizantes. Mas estes cursos tinham um caráter de instrumentá-los como usuários de informática e não os qualificavam profissionalmente nesta área.

Para melhor compreensão do que foi esse processo, segue abaixo um quadro com a evolução dos cursos a partir de 2004 em um dos Centros Públicos.

Tabela 14 - Oferta de itinerário formativo CPFP Armando Mazzo - 2004 a 2006.

\begin{tabular}{|l|l|l|l|}
\hline & \multicolumn{1}{|c|}{2004} & \multicolumn{1}{c|}{2005} & \multicolumn{1}{c|}{2006} \\
\hline PIQ I & Pedreiro & Pedreiro & Inclusão Digital \\
\hline PIQ II & $\begin{array}{l}\text { Encarregado } \\
\text { de Obras }\end{array}$ & $\begin{array}{l}\text { Encarregado } \\
\text { de Obras }\end{array}$ & Inclusão Digital \\
\hline PIQ III & $\begin{array}{l}\text { Mestre } \\
\text { de Obras }\end{array}$ & $\begin{array}{l}\text { Mestre } \\
\text { de Obras }\end{array}$ & $\begin{array}{l}\text { Elétrica } \\
\text { Hidráulica } \\
\text { Comandos Elétricos } \\
\text { Pintura e Gesso } \\
\text { Autoconstrução }\end{array}$ \\
\hline
\end{tabular}

Fonte: Observatório da Educação e do Trabalho DET/ SEFP/ PSA.

Os cursos que se distribuíam em um itinerário formativo nos quatro ciclos do PIQ, passaram a se localizar como cursos desenvolvidos apenas no PIQ III. Os cursos que constam do PIQ III eram ofertados em módulos durante os anos em que o aluno estivesse estudando, com exceção do curso Autoconstrução que foi criado em 2006, que, na verdade, consistiu na tentativa de colocar em um único curso conhecimentos básicos sobre construção civil, de modo que pudessem ser mobilizados pelos alunos para finalidades domésticas ou comunitárias: levantamento de paredes, pintura, pequenos trabalhos em hidráulica. $\mathrm{O}$ itinerário oferecido anteriormente pode ser observado na Tabela 9.

Em 2007, ocorre mais uma alteração. Em uma reunião com a equipe diretiva do DET, foi comunicado às diretoras e assistentes pedagógicos dos Centros Públicos que, a partir deste ano, não haveria mais atendimento no PIQ III, com exceção das salas de continuidade dos PIQ’s II. Essa decisão de seu em virtude do cumprimento da LDB, que atribui ao Estado a 
responsabilidade do ensino médio, e não ao município. Dessa maneira, nenhuma matrícula nova deveria ser efetuada nesse ciclo, o que trouxe apreensão à equipe, uma vez que somente no PIQ III era ofertada a qualificação profissional, e isso significaria praticamente extingui-la. Dessa maneira, a razão de ser do Programa, integração entre elevação da escolaridade e formação profissional, estaria descaracterizada, uma vez que o PIQ I e o PIQ II estavam trabalhando apenas com formação em informática básica.

A fala de uma das diretoras reflete essa preocupação:

Então, a questão é da indefinição de continuidade do PIQ III, que a gente só vai ter a continuidade por conta do PIQ II final e do término do profissionalizante. Eu acho que o profissionalizante se tornou o carro-chefe, eu vejo. $\mathrm{O}$ aluno nos procura porque tem um outro olhar, tem um outro encaminhamento, ele só não vem buscar escolaridade, elevação de escolaridade. É junto, elevação de escolaridade com algo mais, onde ele possa sair e se inserir no mercado de trabalho logo que ele sai já. Eu acho que a gente tem que buscar uma continuidade e eu acho que existem, existem parcerias. Eu acho que não cabe a nós buscarmos essas parcerias. Eu acho que aí é à Secretaria, Departamento-Secretaria, mas não deixar o programa acabar. Eu acho que é um programa que vem crescendo. Pelo pouco que eu conheço, pelo pouco que eu fiz parte, eu vejo um crescimento, um trabalho de uma equipe bem comprometida, pelo menos a nossa aqui. Mas, assim, essas indefinições, se o PIQ 2 vai poder, o que é o fundamental, ter o profissionalizante, como que vai ser isso, como que vai, junto com a Informática, a Informática vai ser mais uma matéria do núcleo comum? Porque, hoje, é de quatro horas. E o profissionalizante, com quantas horas ficaria? Eu acho que os que nos procuram, eles nos procuram porque eles vêm o programa, um programa bom, um programa que deu certo. E eles querem voltar. É gozado que os que estão se formando não querem ir embora. Já fizeram cadastro de interesse pra cursos livres. Então, é porque eles se sentem bem aqui. E muito dos nossos alunos não estão nem na área, estão em outras áreas, mas querem continuar. Então, eu acho que não dá pra falar "não, pronto, acabou, fecha o livro porque não vai dar mais certo". (DIR3, 2006)

Apesar de estarem presentes, na fala da diretora, idéias relacionadas ao mito da empregabilidade, ou seja, a de que o aluno faz o curso e consegue se inserir no mercado de trabalho, é importante chamar a atenção para a situação descrita de indefinição e instabilidade do Programa.

Segundo o depoimento de uma das professoras:

[...] a gente sabe que é importante o PIQ III, pra cidade e principalmente pra essas pessoas que vêm fazer o PIQ aqui, a gente sabe como é a possibilidade de inclusão, a gente atende bastante o aluno com deficiência e sabe que apesar de toda a desestrutura que tem o programa, ainda é um programa bom, quando a gente compara com os outros programas que a gente tem, que 
a gente já acompanhou em outras escolas, e agora a gente sabe que o programa vai acabar e a gente se sente assim muito triste, por que eu acho que dá pra continuar, que dava pra conseguir verba pra ele, porque em São Bernardo por exemplo, é uma prefeitura e também oferece. Bom, eu estava falando que a prefeitura de São Bernardo também oferece o ensino médio, então a gente fica pensando, por que então que vai acabar aqui, os professores pelo menos acreditam que tem demanda que só vinha crescendo, então a única questão que deixa a gente, agora, no momento assim mais... com uma incógnita maior é como sustentar esse programa em Santo André, como fazer, se tem demanda pra ele, como conseguir através da lei, ou com outros recursos, ou com parceria, como conseguir sustentar esse programa. (Gisela, 2006)

É visível, por um lado, nos dois relatos, o comprometimento com o Programa e sua defesa como uma experiência que apresenta bons resultados e que precisa ser mantida. Por outro lado, a idéia da parceria é muito evidente, como se isso fosse um caminho já naturalizado. A professora Gisela levanta, ainda, a possibilidade de uma forma de financiamento para o Programa e também coloca a parceria como uma saída.

Em 2007, não foram abertas novas matrículas para o PIQ III e as salas foram compostas apenas com os alunos oriundos das turmas de PIQ II Final. As diretoras elaboraram um documento propondo que os cursos profissionalizantes voltassem a ser oferecidos nas turmas de PIQ II, e não perdessem uma das principais características do Programa que é a integração entre elevação de escolaridade e formação profissional. Desta maneira, os Centros Públicos voltaram a organizar seus itinerários distribuindo os cursos nas turmas de PIQ II Inicial e Final, e nas de PIQ III que foram mantidas. No entanto, introduziuse uma diferença essencial. Com a autorização do PIQ junto ao Conselho Municipal de Educação, este deixou de ser um curso informal e passou a se inserir na legislação da Educação de Jovens e Adultos, que regulamenta a carga horária. Com isso, a carga horária do ensino profissional teve uma diminuição de $50 \%$, aspecto que será abordado no item que trata da proposta pedagógica.

Essas dificuldades se apresentaram em decorrência da ausência de uma linha própria de financiamento para o Programa, o que faz com que ele tenha de se re-adequar constantemente. Em decorrência, a instabilidade de propostas, e de planejamento geraram uma série de descaracterizações na proposta original, principalmente no que diz respeito à relação entre educação básica e qualificação profissional.

Outra importante indefinição do PIQ é a forma de contratação dos professores. Em 2001, com a entrada das entidades conveniadas, a questão administrativa das contratações foi, em grande parte, resolvida ao abandonar o modelo da seleção pública, que mantinha o 
professor contratado por, no máximo, um ano, gerando constante rotatividade de formadores. Como já foi comentado anteriormente, a contratação realizada por entidades conveniadas poderia resolver o problema, garantindo um quadro profissional permanente. Além do que, as entidades conveniadas, por sua experiência em formação profissional no âmbito sindical e/ou nos movimentos sociais, estariam selecionando profissionais mais afinados e comprometidos com a política educacional proposta. Porém, de 2005 em diante, não foi essa a situação que se estabeleceu. Por problemas financeiros e/ou administrativos, os profissionais passaram a estar sujeitos à grande instabilidade profissional. Uma vez por ano, praticamente, todos trocavam de entidade, o que fazia com que os professores que estavam contratados pela Escola Sindical São Paulo, fossem desligados desta e contratados pelo CES, pelo CEEP ou outra entidade ligada a um outro Centro Público. No ano seguinte a situação se repetia, voltando ao convênio de origem. A partir de 2006, além da troca de entidades, os professores que trabalham com as disciplinas da base comum também foram orientados pelo DET a prestar uma seleção pública para professor do Programa, como forma de melhor garantir sua situação profissional. Porém, como já havia ocorrido anteriormente, a seleção pública só permite a contratação por um período de seis meses, podendo ser renovada por mais seis meses. No início de 2007, os professores, que estavam terminando seu contrato pela seleção pública foram recontratados pelas entidades. Ao final do primeiro semestre de 2007, voltaram a prestar a seleção pública, e ficaram contratados até o final de dezembro, com o contrato de seleção sendo renovado por mais seis meses, até o final do primeiro semestre de 2008. Em todas essas situações de seleção pública, os professores tiveram receio de não serem mais contratados, uma vez que a seleção, por ser pública, possibilita a entrada de novas pessoas no Programa, mesmo tendo como critério principal de seleção a análise de currículos. Alguns professores se recusaram a prestar a última seleção e preferiram "correr o risco" de permanecerem contratados pelas entidades. Isso ocorreu, pois, a partir de 2007 foram filiados ao $\operatorname{SINPRO}^{24}$, o que lhes garantiu alguns direitos a mais em relação à contratação pela seleção, como o pagamento por hora aula, cesta básica, auxílio transporte e direito a férias e recesso. Na contratação pela seleção, a carga horária é fechada em 20 horas, não há auxílio transporte e direito a férias, uma vez que o contrato tem a duração máxima de um ano. Esse processo gerou desgaste nos professores e nas entidades, o que transparece nas falas:

Primeiro essa articulação, se é uma parceria, se é um convenio, ela precisa ter os direitos e deveres, e precisa ser observado isso o tempo inteiro, A

\footnotetext{
${ }^{24}$ Sindicato dos Professores.
} 
articulação com o convenio, com essa $\mathrm{ONG}$, ela não pode ser uma terceirização pura e simples; então, na verdade, ela deveria garantir, potencializar coisas que o poder público não consegue oferecer, e na verdade ela vem, no meu ponto de vista, ela vem, ela está servindo de instrumento para, reservada as devidas proporções, precarizar algumas relações, e aí eu acho complicado [...]. (CORD3, 2006)

[...] e aí, de um tempo pra cá, ainda tem todos aqueles problemas de contratação, porque aí acaba minando a equipe também; então, se antes, mesmo tendo aquela coisa que você minimamente conseguia trabalhar um pouco na unidade, hoje é mais difícil, porque está todo mundo 'chutando a sombra', o pessoal está totalmente desvinculado; sinto também porque aí o pessoal que tem acúmulo na cidade também entregou pra Deus [...] E do ponto de vista dos convênios, eu não sei por onde apita. É aquilo que eu falo, eu sinto dificuldade porque a gente fica meio amarrado, não tem nem por onde fazer e nem o que fazer. Na verdade, esse ano, a gente tem mais dificuldade, que nem o convênio, porque quem está vinculado [...] hoje é basicamente Secretaria, não tem mais ninguém da equipe aqui. E aí eu não vou chegar para um professor e falar, vamos fazer uma formação no sábado, entre nós, porque precisa fazer um ajuste lá na frente, porque quem vai fazer esse ajuste ou pagar esse ajuste não sou eu é o outro convênio, então você fica totalmente... Então desestrutura, e aí eu acho que a gente tem um problema. (CORD1, 2007)

Essa mudança de professor, a todo momento, também, de três em três meses ta mudando professor, ta demitindo professor, toda hora isso, você não consegue manter uma formação continuada, motivação. [...] de não sentir assim valorizado, de ser trocado todo ano, os professores não serem fixos realmente no programa. (Gisela, 2006)

Só que com a criação, com a contratação de professores pelas ONG's, gerou uma série de problemas, porque as pessoas são contratadas, demitidas, contratadas, demitidas, isso gera um problema tanto na questão administrativa quanto pedagógica, enfim tem uma série de questões. [...] $\mathrm{Na}$ maior parte das vezes quem administra isso é a prefeitura que acaba dando, vamos dizer assim, as ordens para as ONG's e isso acaba dando uma série de problemas, que acaba revertendo pro projeto mesmo, porque hoje quem está, se a gente for ver quem está no projeto e foi contratada pelas ONG's, muitas que iniciaram o projeto não estão mais. Muitas coisas a gente já perdeu, muitas pessoas que começaram não estão mais aí. Da rede, a gente tem o mínimo, não sei em porcentagem quanto, mas tem poucas pessoas que estão desde o começo. Isso acaba perdendo um pouco. (AP3, 2007)

Então, alguns professores que estavam contratados pelo convênio passaram por uma seleção pública e que foram na verdade ao invés de beneficiados, prejudicados, porque hoje eles estão finalizando o contrato da seleção pública e não podem ser contratados novamente nem por seleção pública, nem pelo convênio. Porque o convênio não tem o recurso. Poderiam sim, se o convênio tivesse recurso, mas não tem, então esses que foram privilegiados na seleção pública porque trouxeram maior quantidade de título e tiveram maior experiência da educação de jovens e adultos, foram chamados pra trabalhar no Programa e hoje estão fora do Programa. Então, a gente investiu na formação deles, a gente trabalhou com eles, eles se interaram do Programa e hoje estão fora. [...] Eu estou preocupada com o Programa no próximo ano, porque serão professores novos que virão trabalhar, e tudo o 
que a gente investiu com esses professores, meio que se perdeu. Espero que a gente consiga de alguma maneira, que a maioria dos professores sejam contratados pelo convênio, uma vez que eles têm que ficar um tempo sem ser contratados por seleção pública. (DIR2, 2006)

$\mathrm{Na}$ ausência de uma política de gestão clara, os coordenadores, que dividem com a prefeitura, através de suas entidades, a execução do PIQ, apresentam suas preocupações no que toca ao papel das entidades nesse processo:

[...] eu acho que ela (a parceria) deveria potencializar o programa pelas facilidades que a Prefeitura não tem e a ONG tem, de ir buscar parcerias de estabelecer convênio, isso eu acho que enriquece, é um papel que o Estado é muito lento, muito pesado, e não consegue fazer. Se o Estado conseguir mudar essa concepção acho que até elimina o papel das ONGs. Só que o Estado é ineficiente nesta questão e as ONGs, na verdade, elas entram em um espaço que é muito interessante, só que o que acontece? A ONG por ser a parte mais frágil, ela acaba às vezes abrindo mão dessa concepção mais vanguarda, mais potencial e acaba sendo um instrumento que dificulta, que ao invés de articular, ela cria uma relação que pode ser precária. [...] Então, eu acho que a relação de parceria, pra resumir de novo a questão da parceria público e privado e do terceiro setor, ela precisa ser revisada, em cima dos problemas que apresenta. Então assim, se o Estado, ele acha que é importante ter como parceiros as ONGs, ele precisa também ouvir um pouco o outro lado e aceitar as contribuições dos parceiros, por que assim, seja micro ou macro, a contribuição maior, porque a relação ela é muito sufocante, nós estabelecemos, vocês cumprem e ponto. (CORD3, 2006)

Do ponto de vista ideal, eu acho assim, acho que se tem uma história, nessa questão, tem uma experiência nessa questão de desenvolver isso, com erros, com acertos, com qualidades e com defeitos, eu acho que tem uma série de coisas nesse sentido e quando vem pra Santo André, e aí na verdade quando se começou a discutir a questão da introdução do PIQ, uma das coisas que a gente apostou é que seria um espaço pra que a gente pudesse fazer uma discussão, construir uma opção e amarrar minimamente uma proposta. Aí teve a decepção do ponto de vista de uma proposta fechada, amarrada, que em nada rompe com a organização do tempo e da escola, nada, não rompe com nada da estrutura da suplência no Estado, mas aí ficou naquela esperança de que a gente pudesse dentro dessa organização conseguir brechas e cunhar pra poder fazer alguma coisa. [...] Mas de qualquer forma, dentro desta questão, dessas brechas do ponto de vista mais pedagógico, o papel nosso era trazer um pouco dessa experiência e tentar tencionar pra avançar, e é isso que eu estou reclamando muito. Eu acho que a gente contestar, a gente criticar, a gente bater de frente, entre aliados, a perspectiva é a de avançar, ninguém ta querendo puxar o tapete de ninguém, agora tem que ter essa compreensão, se não tem essa compreensão fica difícil trabalhar por que se não você dá um espirro e o cara ta achando que você ta fazendo alguma coisa, a nossa idéia era um pouco essa, era enfrentar com a maior transparência e tranqüilidade 'eu acho que isso está errado, isso está certo, a gente pode avançar aqui, pode avançar lá', só que do ponto de vista pra cima a gente tem muito pouco espaço pra fazer isso, ou quase nenhum. Na verdade, a gente tem muito enfrentamento com o pessoal, quando queria empurrar informática pra todo mundo de qualquer jeito, do ponto de vista da organização das turmas etc. mesmo da visão que se tinha do ponto de vista 
da legislação educacional, algumas coisas que eram meio... Porque na verdade você tem uma preocupação com o aluno que está aqui hoje mas amanhã ele pode estar em Guarulhos, em São Paulo, e aí é um outro sistema, é outra coisa e aí ele tem que ter o mínimo de garantia pra validar o que ele já fez, e algumas coisas eu acho que já estão muito largadas, então você tem muitos enfrentamentos desse tipo. Por outro lado, eu acho que aqui na unidade a gente conseguiu trabalhar legal, várias coisas; então, do ponto de vista honesto e sincero, eu acho que esse seria o papel do convênio, trazer a sua experiência, pra somar a uma proposta a intencionalidade do ente público, com a facilidade de que, e aí a gente tem que reconhecer isso, quer dizer, uma ONG, uma entidade desse porte, ela tem uma maior flexibilidade do ponto de vista da gestão pra permitir a experimentação, coisa que o poder público, que faz concurso, que faz isso e aquilo, vai cada vez se amarrando e se engessando mais, quando do ponto de vista da experimentação, acho que seria este o papel da entidade, agora na medida que a gente não participa, não consegue discutir, não consegue falar nada, a gente corre o risco na verdade de ser uma terceirizada do processo, uma [...] vamos dizer assim, a gente corre esse risco, e esse que eu acho que é o problema, porque na verdade o que você poderia trazer de mais significativo, você não traz, então acaba só se utilizando essa possibilidade de flexibilizar as relações e flexibilizar a organização do trabalho. Acho que esse é o enrosco. (CORD1, 2007)

O papel de agregar, auxiliar, de ajudar na administração de maneira geral, do Centro Público, do Programa. A gente sempre costuma dizer aqui neste Centro Público que o convênio não foi eleito para nada, quem foi eleito para alguma coisa foi o prefeito, o prefeito por sua vez escolheu uma série de pessoas de sua confiança, então é legítimo o prefeito ser eleito e escolher essas pessoas, então é legítimo essas pessoas definirem efetivamente o que o Programa vai fazer, não vai fazer, vai deixar de fazer. E do ponto de vista do convênio, o que é legítimo o convênio fazer? Desde que não sejam coisas que não firam a crença da nossa entidade [...] desde que não seja isso, é colaborar o máximo possível na execução do que se planeja, do que se define. Em todos os espaços, sempre que é possível, a gente sempre coloca a opinião do convênio, mas não é uma coisa que assim no dia a dia tenha uma diferença absolutamente importante com que a prefeitura tem de definição. Não há nada assim que seja vergonhoso para [...] fazer em função do que a prefeitura define. Porque, no dia a dia, são métodos distintos, um pode ser melhor, outro pior, mas quem define no caso é a prefeitura e o convênio vai colaborar nesse sentido. (CORD2, 2006)

Esses posicionamentos refletem, em maior ou menor grau, a defesa das entidades, de suas experiências e concepções do ponto de vista do acúmulo sobre formação profissional e educação básica, construído no processo relatado neste texto. Há, por trás das falas, uma aceitação política dessa relação de subordinação que se estabelece entre entidades prefeitura. O que a pauta, é a intenção de utilizar este espaço público que, com todas as precariedades, ainda se apresenta como local onde se realiza a oferta de educação ao trabalhador, onde essas entidades procuram contribuir com essa política. Além disso, é preciso reforçar a existência dessas políticas propostas por um governo que se assume democrático e popular, na intenção 
de se contrapor a uma política educacional do período do governo $\mathrm{FHC}$, que organizou a educação e a formação profissional de forma dual e seletiva, deixando no abandono a formação inicial e continuada de trabalhadores, antes denominada educação profissional básica, sem nenhuma forma de regulação e dissociada do Sistema de Educação Básica. Como é sabido, não havia, no período, linha de financiamento para a Educação de Jovens e Adultos, além de as políticas governamentais imporem a subordinação direta da formação profissional ao mercado de trabalho, vinculando a idéia do empreendedorismo desconectada das políticas de geração de emprego. Nesse sentido, essas entidades, que por sua história se posicionaram contra esse modelo, vêem neste espaço alguma possibilidade de realização de seus projetos, em consonância com uma política pública municipal que partilharia dos mesmos objetivos.

Com relação à articulação do PIQ com políticas de geração de renda, ou ações que, de alguma maneira, viabilizem uma inserção no mercado de trabalho, apesar de esta articulação estar presente nos objetivos do Programa e aparecer como objetivo nas falas da equipe de direção do Departamento, as ações nesse sentido não apresentam resultados indicativos de que essa articulação foi implementada de forma mais efetiva.

Segundo o Departamento de Educação do Trabalhador, há uma integração nas discussões e projetos desenvolvidos pelo DET, em parceria com a Secretaria de Desenvolvimento Econômico através do DGTR.

Hoje, a Secretaria que a gente tem mais afinidade é a Secretaria de Desenvolvimento Econômico. Quando se dá capacitação, mesmo sendo uma capacitação básica, a gente encaminha para o DGTR, para a Central de Trabalho e Renda que hoje é o Centro Público de Emprego, Trabalho e Renda, então há sempre trocas de informações, encaminhamentos; muitas vezes acho que as condições que do mercado, da própria situação concreta é que dificultam que se faça algo a mais. As discussões sempre foram muito boas, as intenções foram boas, mas se perdeu nas condições, em buscar condições. Então, sempre se teve a intenção de dar cursos, de dar formação, de se planejar, o próprio PNQ é uma articulação conjunta com o DGTR. [...] E o PIQ também, a gente discute os cursos em si, qual é a necessidade, estamos sempre solicitando para que levem discussões, palestras, orientação quanto ao cooperativismo, a economia solidária. Tivemos, há um tempo atrás, várias palestras que eles deram. [...] Tem o programa ' Mais Igual' também. O 'Família Andreense' tenta articular várias políticas, estão aí, o Departamento de Geração de Trabalho e Renda, a assistência social; se discutem estratégias para se tirar as pessoas da situação em que está. (DET2, 2007)

Os participantes do PIQ enfatizam a existência de uma relação frágil, que apresenta descontinuidade. 
[...] vejo que tem muito pouca intermediação, porque os alunos quando saem daqui, a gente tem história de alunos que avançaram, que continuam na área, que melhoraram muito no seu emprego, do que vieram buscar, a gente tem notícia disso, mas é muito pouco em relação à quantidade de formandos. [...] $\mathrm{E}$ a história que a gente tem dos alunos, desses alunos que eu me referi, eles buscaram por suas próprias pernas. Não foi através de programas de intermediação. (DIR2, 2006)

Olha, foi tentado com o grupo do terceiro eixo do PIQ, tentou-se fazer uma interface com as empresas, buscando a mão de obra dentro dos programas, mas eu acho que isso ainda é muito superficial, vamos dizer assim, aqui do Centro eu só tenho três pessoas que fazem parte da Ação Triângulo ${ }^{25}$, que foram selecionadas [...] (quando pequenas empresas) da comunidade ou das comunidades ao redor precisa de pessoas, eles vêm buscar aqui, então eles colocam uma plaquinha e eles fazem a seleção. As pessoas que têm interesse vão até lá, passam pelo processo seletivo de lá e se empregam ou não. É um pouco isso o que a gente faz, agora, com políticas mais diretivas a gente não conseguiu ter resultado não. (DIR1, 2006)

Então, eu acho que não está muito definido qual é o papel do DGTR ainda, por isso que eu convidei esse grupo (o DGTR) pra estar vindo aqui no Centro, primeiramente pra conhecer o Centro, e aí estar sentando comigo e com o coordenador da parceria pra realmente planejar, e projetar qual vai ser o papel do DGTR, porque eu acho que o papel é fundamental quando o aluno ele se forma, ele está desempregado, só que ele saiu com a qualificação. Então, como que agora o DGTR, [...] ele pode contribuir para com esse aluno [...] no campo do trabalho. (DIR3, 2006)

Tivemos uma reunião com o DGTR......com o curso [...] eles começaram, mas não foi para frente. (AP1, 2006)

A gente tem a Central de Trabalho e Renda, que agora tem outro nome, que seria para estar fazendo essa ligação, mas que a gente sabe que pouco acontece. Tinha em dado momento a Central de Autônomos, que fazia um trabalho junto com o nosso Centro Público, fez muito. Tem o DGTR, que deveria estar fazendo esta ponte, mas na verdade, na efetivação, tem intenções, mas que não são efetivadas. Então o PIQ acaba sendo um programa da Secretaria de Educação, a SEFP desenvolve isso, mas o que você faz com esses alunos que são formados pela gente, não tem nenhuma outra articulação com outra Secretaria, a não ser assim, o DGTR, que, em dois ou três dias no ano, vai na escola, fala que tem as políticas de empreendedorismo, cooperativa, fala sobre isso, tenta se incubar algo, mostra para os alunos, fala que existe, mas se perde, acaba não acontecendo. ... é uma intenção... tem muito discurso, mas a efetivação disso não vejo acontecer. (AP3, 2007)

Dessa maneira, um dos objetivos do Programa, o de desenvolver políticas integradas, mostra fragilidade na execução. Caberia analisar onde reside essa dificuldade. Mesmo com o esforço do DET em tentar organizar um grupo que articulasse essas questões, o chamado "Grupo do Terceiro Eixo", composto por três profissionais de carreira do quadro do

\footnotetext{
${ }^{25}$ ONG que trabalha com orientação para reciclagem na cidade.
} 
magistério municipal, que tinham experiência anterior em gerência e coordenação pedagógica na EJA, essas ações se viabilizaram através de experiências pontuais. Esse grupo tinha um acompanhamento mais próximo do Observatório da Educação e do Trabalho.

Assim, o Programa apresenta deficiências que o comprometem seriamente, no que se relaciona ao financiamento, sua própria gestão interna, e na relação com outras políticas que viabilizem seus objetivos em relacionar a educação e o trabalho.

O papel do Observatório também é questionado pela maior parte dos entrevistados. Mesmo considerando as iniciativas já citadas aqui pelos entrevistados do DET e a relação que o Observatório estabelece com a Secretaria de Desenvolvimento Econômico, sua interferência no Programa não é percebida pelos agentes que estão fora do grupo do DET que determina as orientações.

[...] o papel que ele deveria ter, na verdade, era nos dar subsídios de pesquisas, dados, pra gente conseguir construir os próprios itinerários, ou aquilo que é demanda. A gente percebe uma dificuldade muito grande. Hoje, eles estão mais centrados em dados propriamente de formatação e quantificação de atendimento, pesquisas mais voltadas com relação ao curso, se foi de qualidade ou não foi; ele está muito centrado nisso. Essa parte mesmo de subsidiar com dados, eu acho que eles acabam não tendo pernas pra desenvolver. Pelo menos é isso que eu consigo visualizar. (DIR1, 2006)

No trecho acima a diretora se refere ao fato do Observatório ter dedicado seu tempo ao levantamento de dados do Programa, no entanto, mesmo no que toca a isso, o Observatório não tem conseguido realizar a tarefa a contento.

Então, o Observatório veio pra procurar, pra saber qual é essa necessidade. Hoje, neste Centro Público, tem mais que isso. Eu percebi que o Observatório ele veio pra fazer parceria também nesse perfil de aluno, nesse aluno que a gente quer que ele continue dentro da escola,; ele inicia aqui na escola e vem buscar essa capacidade, essa competência dentro da escola, não saia da escola, venha pra cá sempre buscar mais. A escola está aqui pra atendê-lo. E além disso, o Observatório agora vai nos auxiliar na certificação desses alunos. Neste ano, que a certificação foi pelo Observatório, eu não posso dizer que ele veio pra facilitar. Foi um complicador... [...] porque nós tivemos que mandar as planilhas dos alunos certificados no ENCCEJA, pra que eles confeccionassem os certificados, e esses certificados foram pra gráfica, alguns alunos não receberam esses certificados até hoje pra você ter uma idéia. (DIR2, 2006)

Então, assim, nós chegamos a sair do topo de maior evasão dos seis Centros, passamos pro terceiro lugar, mas agora nós passamos de novo pro topo. Tá, e aí? Nós passamos e aí? Eu pergunto pro Observatório. O que o Observatório está me ajudando pra sanar essas dificuldades? Por que existe essa evasão? Ah, é por conta do trabalho. Realmente, ele busca o trabalho. Tudo bem, ele 
busca o trabalho, mas ele tem que buscar junto com o trabalho a qualificação e a elevação de escolaridade porque isso vai fazer com que ele se qualifique melhor e tenha uma posição melhor no meio do trabalho, no campo, na inserção. Então, assim, o Observatório, eu acho que existem grandes falhas, não sei qual que é o papel do Observatório. Se você me perguntar: qual que é o papel do Observatório? Não sei. Certificação? [...] Eu estou entregando agora em dezembro a certificação de 2005 [...]. (DIR3, 2006)

Nos relatos das diretoras há queixas no que se refere à relação com o Observatório e à definição de seu papel. Pode-se supor que, ou as pesquisas sobre o mercado de trabalho destinadas a orientar as propostas de cursos não conseguem ser realizadas a contento, ou as informações ficam circunscritas ao DET e não são publicizadas e, portanto, não apropriadas pelos núcleos pedagógicos dos Centros .Públicos. De qualquer modo, existe uma carência de orientação na proposição dos cursos, uma vez que são os núcleos pedagógicos que elaboram os planos de trabalho.

Os coordenadores também apontaram problemas na definição do papel do Observatório, o que também compromete esta importante ação do Programa, a oferta dos itinerários e dos cursos:

Olha, eu não tenho muito contato com eles, quem tem mais contato é a diretora, mas o que eu vejo é que o Observatório, que eu percebo, é que ele tem um caráter de coordenação. Então tem uma premissa dos Observatórios de não ser o agente executor, uma vez que a sua observação vai ficar comprometida, porque por mais que a gente se esforce e a gente gosta do que faz, às vezes a gente não enxerga sobretudo as coisas ruins que a gente faz. Acho que tem um desvirtuamento da função do Observatório que devia observar e dar indicadores, mas acho que, pelo que percebo, tem um caráter de coordenação, não de pesquisa. Eu não vi nenhuma pesquisa feita por eles, a não ser no início, mas ultimamente não vejo nada. Coordenação, execução, eu acho que temos problema com o nome ou com a função. (CORD2, 2006)

[...] o papel dele é muito importante no desenho da política. O que ocorre é que o Observatório, ele é um instrumento fundamental pra você monitorar e você dar o feedback para as transformações. Ocorre que o Observatório perdeu,... [...] mas ele tinha um desenho que ele conseguia, estava tentando conseguir captar isso, as tendências, e você percebe que a questão do Observatório, ela é muito ousada, e ele tem mais desafios que o PIQ, na minha opinião, porque ele vai ter que ir lá na frente, olhar as tendências, tem que monitorar e sugerir propostas, pra fazer isso é um movimento, teria que ter uma concepção, teria que ter uma independência, teria que ter mais recursos, teria que ter uma série de... porque na verdade [...] ele acabou fazendo muita coisa que não era do papel dele, inclusive fazia questões administrativas, fazia projetos, coisa que não era, então ele perdeu essa [...] então se ele voltar a resgatar esse papel que estava desenhado a princípio, acho que ele pode contribuir nessas questões que eu estou dizendo, os problemas do PIQ, coisas que a gente começou aqui meio que fazer do jeito que a gente conseguia. O Observatório poderia contribuir mais. [...] Então o 
que a gente faz, a gente executa e não consegue sistematizar, não consegue parar pra pensar. O Observatório poderia fazer isso. "Olha, os caras estão executando lá, tem algumas idéias interessantes, vamos ver", só que ele não consegue fazer isso, pelo menos até agora não conseguiu, e não consegue sistematizar o que a gente faz na prática, ou tem muito pouca percepção do que a gente faz. Então, na verdade, o que ele deveria ser um eco das coisas que estão acontecendo, a primeira diretriz é se você pensar numa concepção democrática, você desenha um programa junto com a sua equipe e a partir do funcionamento você vai monitorando, vai agregando elementos pra você retornar através de uma avaliação de impacto ou até do próprio monitoramento pra retornar no desenho da política, e aí você contribui. Até agora o Observatório, o próprio perfil, as coisas, as sugestões que eles têm feito, elas não levam em conta esse acúmulo histórico do que acontece. (CORD3, 2006)

O processo realizado para a proposição dos cursos será apresentado no próximo item, que trata da proposta pedagógica.

Com relação à questão do financiamento do PIQ, além das dificuldades e comprometimentos que foram apresentados, é importante mostrar, também, como o DET vê essa questão e o que propõe para resolvê-la. O primeiro aspecto abordado é a questão da legislação e as contas públicas.

[...] o problema que a gente tem aí no PIQ, porque o PIQ elegeu os três eixos fundamentais, que seriam o ensino propedêutico, a formação profissional e a monitoria, o estágio de monitoria. Infelizmente, aqui no nosso país, a gente se esbarra em algumas questões burocráticas, infelizmente mesmo, o tribunal de contas no nosso país é quem define o que é educação. Então, as despesas que por ventura a gente possa fazer pra educação, se o tribunal entender que aquilo não é educação, na compreensão deles, eles glosam e deixam as secretarias de educação com as mãos atadas porque eles entendem a educação do modo que eles querem compreender, aquela educação tradicional. Nada mais além disso. Então nós temos, possivelmente teremos algumas dificuldades com essa coisa do Tribunal de Contas, mas a gente tem conseguido produzir assim, fazer com que eles compreendam que educação não pode ser dissociada, não pode ser separada, e, com isso, a gente tem conseguido dar continuidade ao projeto. (DET1, 2007)

No município, vamos pegar aqui o caso de Santo André, desde o início, [...] desde que eu entrei sempre se atuou nesse campo, o próprio Departamento de Educação do Trabalhador, quando o Celso cria, era para estar pegando esse eixo, para estar fomentando isso, mesmo que com posições, entre aspas, questionadas pelo Tribunal de Contas. Hoje a educação profissional aliada ao aumento de escolaridade para o adulto, em muitos municípios, não se faz porque o recurso do município com educação não pode ser gasto com educação profissional. (DET2, 2007)

Os relatos são importantes porque mostram como a própria estrutura governamental é elemento de restrição ao financiamento do Programa. Mesmo com a publicação do Decreto 
5154/04, que prevê a integração de políticas de EJA com a formação inicial e continuada, a interpretação legal sobre gastos com educação parece não considerá-la. O Tribunal de Contas, conforme foi observado por DET1, não considera a qualificação profisssional como educação, e principalmente, não a considera como parte da EJA.

As pessoas que compõem o DET, diante dessa e outras questões, levantam alternativas para a reversão deste quadro. Essas alternativas não são desconhecidas, sendo que algumas, inclusive, estão apontadas nos documentos "Carta de Santo André" e "Carta do Recife".

Um dos grandes problemas que a gente tem [...] $\mathrm{Na}$ verdade existem recursos que poderiam ser utilizados dentro dessa perspectiva. O que ocorre é que, infelizmente, as decisões de Estado são muito demoradas e passíveis de muita discussão e, às vezes, não se levam em conta as necessidades mais reais. E só pra você ter idéia, hoje, programas pra juventude só em nível de governo federal tem mais de cinqüenta programas de juventude, de diferentes Secretarias, de diferentes Ministérios. Se ele fosse canalizado para um programa único tipo esse PIQ, que pega a sua integralidade de formação, aí seria uma coisa bem diferente. Mas o que ocorre com esses programas é em não tendo matricialidade, são feitos retalhadamente, não há uma complementação. Então, o aluno, o cidadão, não consegue fazer $o$ aproveitamento de um curso que porventura tenha feito com o PNQ, um curso com o PROJOVEM, ou um curso que ele tenha feito lá na Secretaria de Inclusão, etc. Então, se esses cursos fossem canalizados para um processo de matricialidade com certeza nós reduziríamos bastante a dificuldade que nós temos com esse financiamento. Existe uma legislação, que agora deverá modificar substancialmente, o FUNDEB, mas com o FUNDEF era aquela dificuldade que eu disse, que é ensino fundamental e se for curso de pedreiro não cabe nesse fundamental, conseqüentemente seria glosado. Com essa nova modalidade, o FUNDEB já dá um direcionamento, já abre essa possibilidade, já fala do ensino agregado, ensino profissionalizante ou propedêutico, então já há uma possibilidade... já abre essa possibilidade, no que pese coloque apenas dentro do ensino médio, mas caberia à sociedade buscar com que isso fosse estendido também para o ensino fundamental. Mas o FUNDEB já recepciona um pouco isso. Agora, para os municípios, teria essa dificuldade, porque se ele é pra esse antigo ensino médio, vai estar concentrado nos Estados e os Estados, infelizmente, ainda têm uma máquina que não consegue perceber isso com bastante visibilidade [...] Então, enquanto o município está sobrecarregado, não tem como absorver esses alunos, mais de 700 alunos em fila de espera, o Estado tem vagas em grande quantidade. Então a modalidade, como é oferecida, essa questão de financiamento ela pode ser resolvida. Aqui em Santo André possivelmente nós vamos conseguir resolver, um pouco, agora, com parcerias do que seria o PMQ, o Plano Municipal de Qualificação, que é feito com o Ministério do Trabalho, e que oferece a possibilidade do ensino profissionalizante com pelo menos duzentas horas; e o nosso pensamento é articular isso com o nosso ensino propedêutico, fazer essa aglutinação e somente assim nós poderíamos oferecer sem grandes problemas o chamado PIQ III, esse é um desenho que estamos fazendo e que possivelmente dará resultado. (DET1, 2007) 
Embora tenhamos o decreto 5154, tivemos alguns avanços ao longo desses últimos dez anos, podemos perceber que ainda a carência é muito grande de recursos específicos para essa área. O Sistema $\mathrm{S}$ consegue dar conta das suas necessidades, no entanto de certa forma, existe uma ausência de articulação dessas políticas que estão vinculadas ao Sistema $\mathrm{S}$, mesmo dos cursos das escolas federais, escolas técnicas, tanto as Faculdades de Tecnologia FATEC's, quanto as escolas federais propriamente ditas, carecem de uma articulação maior com as políticas municipais, e aí os municípios, dado a especificidade do direcionamento do recurso com base na LDB, dos $18 \%$, dos $25 \%$ do Estado, dos recursos próprios do Município, ele acaba tangenciando determinadas perspectivas de programas que você possa vir a constituir. O PIQ é um desafio nacional, ele tem uma especificidade própria, porque ele pretende articular um feixe de políticas, para dar conta das necessidades da população, principalmente tendo como essência a formação profissional. [...] Dada a falta de institucionalidade, ou seja, de legislação específica que direcionasse recursos pra ele, e nós tivemos então, que vir fazendo adaptações desse programa com vistas a ele se encaixar dentro da política de educação de jovens e adultos. Portanto, a EJA vem numa luta nacional e de algumas lutas mais específicas, conquistando recursos dentro do FUNDEB que agora, recentemente, foi aprovado. Você está limitado pela responsabilidade do município, que, no máximo, pode se responsabilizar até o ensino fundamental, e portanto uma das modalidades desse programa acaba ficando de fora, e acaba ficando dependente das parcerias com convênios, com entidades, e de projetos que a gente possa captar recursos. O Observatório constatou isso, como é que isso rebate na programação, no itinerário formativo e nos cursos que são ofertados? Ele rebate a partir das limitações do que se pode gastar com recursos municipais e do que você consegue captar tanto com recursos do FAT [...] Primeiro, nós temos que estabelecer, junto ao FAT, uma articulação mais aprofundada em relação ao próprio PMQ. Não dá pra ter sobreposição de políticas de formação profissional na cidade, política também que a Secretaria de Desenvolvimento Econômico e o Departamento de Geração de Trabalho e Renda também defende, então juntos, a Secretaria de Educação, a Secretaria de Desenvolvimento Econômico e Ação Regional [...] vêm efetuando esforços nesse sentido, de buscar um arranjo político e que dê uma institucionalidade junto ao FAT para que a gente consiga um recurso específico pra esse tipo de formação de política integrada. Essa é uma das saídas que vem sendo trabalhada desde o final de 2007. A outra saída refere-se a elaboração de projetos e captação de recursos. Temos identificado que esse tipo de política se, por um lado, ajuda a somar e trabalhar com ações complementares, por outro lado, ela tem uma deficiência na formatação dos editais, quer dizer, não contribui para dar sustentabilidade às políticas que os Municípios vêm encetando, em especial os Municípios que elaboram, que trazem projetos pros seus Municípios. Achamos também que há que se mudar alguns componentes desses editais, possibilitando uma política de longo prazo, de maior fôlego, de três, cinco anos por exemplo. Nada impede hoje que você elabore um projeto, ele seja bem sucedido e no próximo ano ele seja interrompido, não há uma continuidade, não há uma garantia de que no ano seguinte você pode mandar um novo projeto, na mesma linha de edital que tinha sido aberta e você vai conseguir o recurso. Talvez até não seja esse o objetivo das políticas federais, mas de qualquer forma sentimos essa carência, essa alteração, e a outra alteração refere-se à própria LDB, quer dizer, a LDB tem que procurar compatibilizar todos os níveis e modalidades da educação, em especial a formação profissional. Como é que a gente coloca dentro da política nacional, da LDB, que viabilize a ter recurso de 
forma eqüitativa pra formação profissional tanto pra jovens quanto pra adultos. A quarta questão que coloco refere-se ao próprio Sistema S [...] Não adianta cada instituição, cada autarquia tentar fazer uma política própria, a política tem que estar casada nos níveis que a sociedade está constituída. Se tem Município, que o governo municipal é responsável pela cidade, o governo estadual pelo Estado e o governo federal pelo país, essas políticas têm que estar concatenadas, elas têm que estar organizadas pra atender essas demandas, e não cada instituição ter uma política específica, própria, mesmo considerando as limitações existentes que a gente conhece. (DET3, 2008)

Duas questões podem ser problemáticas na argumentação que DET3 apresenta. A primeira, que trata da articulação com o Sistema $S$, passa por todo o rol de discussões em torno da sua gestão, objeto de discussão presente nos documentos que definem a formação profissional como direito do trabalhador. No que trata da convergência das políticas é correto. No entanto, o sistema $S$ necessita de uma gestão que se proponha a essa direção. Como foi visto, essa formulação está presente nos documentos da CUT e nas proposições resultantes dos Seminários sobre as políticas de qualificação profissional, realizados em Santo André e Recife. A segunda, que considera o financiamento de programas que trabalham com qualificação profissional por meio de verbas destinadas a projetos. A esse respeito, cabe frisar que se, de um lado, tal proposta talvez seja interessante na perspectiva de projetos experimentais, monitorados e avaliados pelos Ministérios envolvidos, por outro lado, subordinar o financiamento de um Programa estabelecido por uma política municipal, mesmo em conjunto com outras linhas de financiamento, as verbas advindas de projetos podem indicar o caráter instável do financiamento público das políticas de educação voltadas à Educação de Jovens e Adultos e Qualificação Profissional e abdicar de uma linha de financiamento público permanente. Essa pode ser uma alternativa para a situação imediata, mas não pode se constituir como alternativa a médio e longo prazo.

\subsection{DESENVOLVIMENTO DA PROPOSTA PEDAGÓGICA}

No capítulo anterior, abordou-se a proposta pedagógica do Programa com o propósito de apreender os seus objetivos e pressupostos teóricos, e de situá-los no âmbito do debate sobre políticas públicas de educação então existente. A análise do trabalho pedagógico, do ponto de vista da integração da qualificação profissional à educação básica, será considerada, neste capítulo, em todo o período de desenvolvimento do PIQ, e propõe 
apontar as mudanças provocadas por decisões administrativas, que alteraram substancialmente os objetivos propostos.

Como se tem enfatizado, a meta principal do Programa é promover a integração entre elevação de escolaridade e qualificação profissional. Os participantes (aqui representados pelas diretoras, assistentes pedagógicos e professores) apresentam diferentes entendimentos, tanto da relação entre educação básica e qualificação profissional, quanto do próprio conceito de qualificação.

Nas falas, há a preocupação recorrente de que o aluno consiga obter a elevação de sua escolaridade e uma profissão:

É para aquelas pessoas que não tiveram oportunidade de estudar, migrantes de outras cidades que vieram para cá [...] a proposta é que eleve sua escolaridade e tenha uma profissão, temos alunos de 14 a 80 anos. (Marina, 2007)

O PIQ é um programa onde a gente concilia a profissionalização e a elevação de escolaridade, é um programa onde a gente atende jovens de 16 a 100 anos, e que não tiveram oportunidade, a grande maioria. são pessoas que não tiveram a oportunidade de fazer a elevação de escolaridade no tempo da educação formal regular. (DIR1, 2006)

É um programa onde o aluno tem elevação de escolaridade junto com um curso profissionalizante, e onde a gente enfoca principalmente essa questão dos três eixos, da consciência critica, da cidadania, enfoca bastante essa postura. (Gisela, 2006)

PIQ é Programa Integrado de Qualificação. Ele junta a qualificação profissional com o ensino regular, tipo supletivo. È uma escola diferenciada, porque ele pega o aluno que está há muitos anos fora da escola e oferece a esse aluno não só o ensino regular; mas também a integração e a elevação da auto-estima. Trabalha uma série de conceitos que ficaram esquecidos na trajetória de vida destas pessoas e junta com a qualificação profissional também. (Dalva, 2006)

É interessante notar que as falas anteriores pertencem a pessoas que se encontram há mais tempo no Programa. Um outro grupo, constituído de pessoas que participam há menos do tempo do Programa, apresentam definições menos precisas, e/ou atribuem maior valor à escolaridade ou à formação profissional, mostrando dificuldades em estabelecer claramente a relação entre uma e outra:

O Programa Integrado de Qualificação, ele visa, ele busca requalificar e capacitar a pessoa, reinserir a pessoa no mercado de trabalho, seja através dos cursos livres que são oferecidos aqui no Centro Público, ou pelos cursos da grade do ensino médio, bem como também o curso de inclusão digital 
oferecido no PIQ II. Então esse curso basicamente visa, uma das diretrizes é requalificar para o mercado de trabalho, requalificar o aluno para o mercado de trabalho. Aí trabalha com EJA, jovens e adultos, principalmente adultos. (Marcos, 2006)

Olha, eu vejo assim, é elevação de escolaridade, com qualidade. Acho que nós temos que buscar essa qualidade, acho que não pode se perder. Nesses dois anos que é o PIQ, de $5^{\mathrm{a}}$ e $6^{\mathrm{a}}, 7^{\mathrm{a}}$ e $8^{\mathrm{a}}$, eu acho que a gente tem muito o que melhorar ainda, principalmente nessa inclusão digital, o que é essa inclusão digita 1. (DIR3, 2006)

O PIQ... então integrar, então, acho que o PIQ se resume em integrar o cidadão que parou de estudar. Como você integra ele à vida hoje, como que você integra essa pessoa que mesmo que vai sofrer uma baixa estima do pai, da esposa [...] essa pessoa que está numa idade avançada, essa pessoa que está hoje desempregado, essa pessoa que está hoje passando dificuldade em casa [...] vamos pegar aí um adolescente mesmo, gravidez na juventude, o adolescente de 18 anos sem perspectiva, ou tem até perspectiva mas ouviu muitos nãos na vida. é de um programa L.A ${ }^{26}$., sabe? Então, o PIQ é isso, eu resumo no integrar, como que você integra essas pessoas hoje para o estudo, para uma mudança de vida. É por formação profissional? É. É por motivação ao estudo, ensino médio, ensino fundamental? É também. Quais são as políticas ideológicas que a prefeitura municipal tem para que os professores arrumem ferramentas para mudar essa cabeça? O PIQ também é isso. O que a escola vai oferecer de estímulo para que quando ele entre aqui ele perceba que não é somente uma escola, seja uma oportunidade de vida, uma mudança na vida dele. O PIQ também, acho muito bonito, quando entra a parte de psicologia. ...O CADE. O legal do PIQ é essa letra I aí, o integrar de novo, como você integra a pessoa na sociedade. (Roberto, 2006)

O PIQ é um programa que o Departamento desenvolveu pra trabalhadores. Então nós temos alunos no Centro Público que são trabalhadores que vêm buscar melhor qualificação pra melhorar no seu trabalho, temos alunos desempregados que vêm buscar uma qualificação pra conseguir o emprego e temos alunos que vêm buscar uma qualificação profissional, pra tentar um emprego melhor; então eles são desempregados, são aqueles que dentro do seu próprio trabalho querem melhorar ou aqueles que vêm buscar um novo trabalho, um novo rumo pra sua vida. (DIR2, 2006)

PIQ é programa de qualificação pra trabalhadores, a gente atende na verdade jovens e adultos, e quando a gente pensa na elevação de escolaridade desses alunos que são trabalhadores, então a gente tem feito aí uma discussão na questão de como esses aluno aprendeu na vida, o que ele trouxe pra escola, valoriza isso e tenta além de dar a elevação de escolaridade que o mercado pede, tem a questão social também, que às vezes a gente tem aluno, alunos assim que já tão até aposentados, mas que eles querem, eles querem saber escrever, saber ler, ter independência mesmo nessa questão, então eles procuram a escola também. Então, eu penso assim que o PIQ, que é orientação de escolaridade atrelada a alguma coisa ligada ao mercado de trabalho, essa concepção que a gente aqui chama de terceiro eixo, que ele tem assim três vertentes, que são os nossos jovens. Que a gente tem adolescentes praticamente também. Nós temos as pessoas, os trabalhadores de 26 a 40, 50 anos, e a gente também tem os aposentados até. (AP2, 2006)

\footnotetext{
${ }^{26}$ Liberdade assistida.
} 
A relação entre elevação de escolaridade e qualificação profissional é definida de duas maneiras, a partir de outras perspectivas:.

Então, inicialmente, ele tinha como objetivo articular tanto as áreas do conhecimento quanto a profissionalização, de forma que a gente conseguisse a profissionalização, chamasse esse aluno para estar estudando e a gente conseguisse articular esses conhecimentos [...] Ele tinha a proposta de não ser o supletivo que a gente vê por aí, ao contrário, dar conta da demanda do jovem e adulto, demandas do mundo do trabalho, articular tudo isso e dar conta do jovem e adulto que a gente atende [...] pensar no que pode ser articulado entre o mundo do trabalho e os conhecimentos que o adulto tem que ter, que a escola tem que dar, tem que oferecer de um forma que fosse significativa para ele. (AP3, 2007)

Eu acho que essa é a característica do projeto do PIQ. Uma educação que é composta para o trabalhador, tem que ter essa parte. Porque não adianta nada profissionalizar, se ele não tem escolaridade. Esse casamento de levar a escolaridade e a capacitação técnica é a solução. E o atendimento que a escola deve oferecer pensando no trabalhador [...] A gente começa a valorizar outros conceitos, de generosidade, de democracia, mais na prática. Porque muitas vezes, na escola, a gente conversa todas essas coisas, mas a prática fica longe. Fica na reflexão da escola. Na parte da qualificação técnica, a gente vê os alunos querendo produzir, querendo fazer os currículos e querendo enviar, fazer as coisas e trabalhar em grupo. Eu acho que essa parte da profissionalização e elevar a escolaridade são características do PIQ. (Tânia, 2006)

Com relação ao conceito de qualificação, também há diferentes entendimentos. No entanto, apesar de consistir uma das questões essenciais do Programa, esta é uma discussão que nunca foi feita no coletivo da equipe. É comum encontrar-se, nos discursos, os conceitos de qualificação e re-qualificação como terminologia de domínio comum, mas nenhum dos entrevistados soube precisar o seu significado. Incorporado ao vocabulário, seu uso subentende, muitas vezes, uma visão pragmática da formação, entendida como resposta rápida a uma situação de ausência de emprego.

O entendimento crítico da historicidade do trabalho, abre a possibilidade de uma apreensão mais ampla dos problemas relativos ao mundo do trabalho e de sua relação com a educação.

Quando o entendimento da qualificação e do trabalho não avança para além da explicação imediata, do senso comum, as atribuições sociais da educação profissional e a importância dos itinerários formativos não são percebidas na sua integralidade. Não se considera, por exemplo, a relação entre a progressão escolar e a progressão no trabalho. 
O conceito de itinerário formativo, tal qual está colocado no Decreto $n^{\circ} 5154 / 04$, define-o como "o conjunto de etapas que compõem a organização da educação profissional em uma determinada área, possibilitando o aproveitamento contínuo e articulado dos estudos". Mas é preciso entender melhor a dimensão conceitual do itinerário formativo.

Itinerário formativo, em sua acepção mais geral, refere-se à:

[...] estrutura de formação escolar de cada país, com diferenças marcadas, nacionalmente, a partir da história do sistema escolar, do modo como se organizaram os sistemas de formação profissional ou o modo de acesso à profissão. (FRIGOTTO; CIAVATTA; RAMOS, 2005, p.49)

Nas reivindicações apresentadas pelas organizações representativas de trabalhadores, o itinerário formativo é definido como uma seqüência de cursos, etapas ou módulos progressivos de conhecimentos, correspondentes às diversas especialidades ou ocupações pertencentes aos diferentes setores da economia, integrados à educação básica, na forma de educação continuada, e deve viabilizar a obtenção de créditos ou certificados escolares reconhecidos pelos Ministérios da Educação e do Trabalho, para fins de continuidade de estudos, e de ingresso ou progressão no sistema de emprego. Esta definição está presente no documento da $7^{\text {a }}$ Plenária da CUT:

Os cursos devem ter formato flexível, apresentar organização modular, de maneira a poder atender às necessidades e diferenciação da população trabalhadora quanto ao tempo e ritmo do trabalho escolar.

É fundamental que os cursos obtenham aprovação legal, através do fornecimento de créditos e certificados escolares reconhecidos pelo Ministério da Educação e do Trabalho, de maneira a serem considerados e valorizados pelas empresas nas negociações, convenções e contratos coletivos. (1995, p.27)

Quando perguntados, parte dos participantes não têm clareza sobre o que seja um itinerário formativo ou ocupacional, ou não conseguem apontar sua relevância para além da formação inicial:

Olha, não sei se vou estar falando besteira, sobre o Itinerário Formativo, sempre tem a preocupação da direção em passar essas informações. Como é o aluno?, De onde ele veio?, Pra onde ele vai? E a formação que nós estamos dando, que tipo de formação é essa. Será que você ta coerente com a nossa proposta de trabalho para você formar o profissional. E aí é o que a gente conversou, é você depois ver qual é a trajetória, ver pra onde esse aluno [...] foi. Não sei, essa é a questão do itinerário formativo? (Marcos, 2006) 
Olha, pra mim o itinerário, ele vem dentro de um conhecimento construtivo, ele vai adquirindo conhecimentos, no decorrer dos anos. E não é porque é um processo que a gente vai fazer com que esse aluno, ele transpasse os limites, ele tem o tempo dele. Eu acho que nós estamos aqui pra informar, pra instruir, não só a parte do núcleo comum, nem só o específico. Eu acho que transcorre, ultrapassa essa parte de educação [...] também a tentar algo mais aí fora, no mundo do trabalho. O que é esse mundo do trabalho? Como montar um projeto, como montar um currículo, como se portar perante a uma entrevista? Eu acho que isso faz parte do itinerário nosso. É por isso que eu falo que ele transpassa só o pedagógico e que também eu acho que a gente precisa melhorar nesse ponto. (DIR3, 2006)

Já ouvi falar, não tenho total domínio [...] vai ter que passar por essas matérias para que ele forme esse aluno [...] por onde ele vai ter que passar para que a gente forme esse aluno. (Roberto, 2006)

Do início do PIQ não mudou muito coisa do itinerário formativo não. O que mudou é que a minha área é uma área que está sempre renovando, então a gente busca conhecer, mas itinerário não mudou muito, mudou mais a questão assim, a gente tinha no começo, no PIQ I um itinerário um pouco mais lento. (Marina, 2007)

Esse itinerário formativo é mais desenvolvido a partir do ensino fundamental para o ensino médio. Os alunos que já concluíram a inclusão digital, que já tem um conhecimento prévio de informática, eles conseguem passar pelo itinerário formativo, vamos dizer assim, da informática. Então eles iniciam lá fazendo as técnicas mais avançadas de informática, elaborando planilhas e conhecendo um pouco mais do computador, pra depois utilizar recursos multimídia. Então eles vão conhecendo como se utilizam, como se agregam peças no computador, na CPU, pra utilizar edição de imagem, pra utilizar áudio e vídeo dentro do computador. Então eles conseguem fazer uma informática avançada a partir de conhecimentos prévios. Esse é o itinerário de informática, por exemplo. Ele vai passando por um percurso de informática, onde ele vai avançando no conhecimento e agregando novos módulos ao computador pra que ele consiga editar imagens, avançar dentro deste conhecimento. (DIR2, 2006)

Olha, antes, quando eu entrei, eu achei que era isso, ele ia aprender, através dos três anos um curso que ia se completando, como eu dei o exemplo dele começar como pedreiro e terminar como mestre de obras, agora eu nem sei se ele se dá em um ano, esse ano eu nem tive mais essa discussão, nem tive mais essa reflexão. Antes, eu entendia que era isso, esse processo de formação através de uma qualificação, não sei se é bem isso. Mas eu entendia que era assim, o itinerário formativo, e completando com as matérias do núcleo comum, quando ele entrava, já tinha, ia dar continuidade a esse curso, e acho que agora ta meio solto. (Gisela, 2006)

Então por que é assim, a gente, PIQ, ai tem lá a base, o PIQ dependendo do perfil e do que ele quer para ele, teríamos oficinas no nosso Centro Público, na área de informática então a gente iria avançar nesse sentido, mas eu penso que ele veio fazer informática, ele gosta de estudar aqui, mas necessariamente ele não precisa fazer oficina aqui, ele pode fazer em outro Centro Público, aqui dentro do nosso Centro Público, eu penso que nas oficinas a gente teria itinerários, na área do escritório mesmo, que a maioria dos Centros na área de informática faz, mas a gente poderia avançar então lá, 
no hardware, na rede, na administração de rede, é uma área, é um leque, ou poderia então ir para a área [...] então seria paginas de Internet, linguagens, $\mathrm{html}$, animações para fazer as figurinhas, seria uma outra, ou então a parte mesmo de edição de imagens de vídeo também, teria uma outra utilidade, eu penso assim. (AP2, 2006)

Você já ouviu falar de itinerário formativo aqui na escola?

Não.

Você nunca ouviu, não tem idéia de que seja isso?

Não. Em julho foi o nosso último encontro de planejamento para o segundo semestre. E em outubro foi um encontro muito rápido do conselho. (Tânia, 2006)

Duas pessoas, que estão no Programa desde o seu início, mostraram deter maior compreensão do seu significado e objetivos:

Então, na realidade, a gente muito pouco tem conseguido dar conta do que os alunos querem, na verdade a gente propõe os cursos e os alunos acabam indo naqueles cursos....são escolhas restritas, não tem um leque [...] Itinerário formativo, não sei o que é isso, não tem, porque se a gente for ver qual a concepção de itinerário formativo, você tem que dar módulos que são fechados, que começam e acabam, tem uma terminalidade, e que os alunos possam escolher o caminho. (AP3, 2007)

O itinerário formativo é uma seqüência mais ou menos de lógica que o aluno pode seguir pensando na sua qualificação. Ele começa o PIQ II fazendo a inclusão, conhecendo a máquina e perdendo o medo. Depois ele pode ir para o PIQ III pensando no seu futuro, escolher alguma coisa que tem a ver com o seu perfil, com profissão e aquilo que ele pretende definir para o futuro. [...] Itinerário formativo é a seqüência que ele poderia fazer. Mas como ele poderia fazer uma seqüência se não existe curso depois disso? Não existe nenhum curso técnico e nenhum curso livre. Eu não entendo que curso livre é a opção para o aluno que termina o ensino médio. Poderia ser o ensino técnico, mas nós não temos. Então o curso livre seria outra opção. Mas também não temos. E o que temos, é muito restrito. (Dalva, 2006)

Esta última fala trata de um dos importantes objetivos do Programa que tem apresentado obstáculos a sua realização: a continuidade do itinerário formativo para além do PIQ. A dificuldade na articulação com outras instituições e o fato de não haver um sistema educacional que integre esses conhecimentos de forma a validá-los vem impedindo que os alunos continuem seus itinerários.

No ano de sua implantação, em 2003, por não ser um curso autorizado pelo sistema de ensino, as cargas horárias foram propostas tendo como parâmetro o ano letivo regular, porém sem obedecer a legislação vigente. Dessa maneira, cada ciclo tinha como carga horária 800 horas anuais. 
Todos os ciclos do PIQ teriam a duração de um ano, prevista uma carga horária proporcional de $40 \%$ para a qualificação profissional e 60\% para a elevação de escolaridade. A justificativa para essa decisão consistiu no fato de os alunos jovens e adultos já deterem conhecimentos, saberes e experiências, construídos em suas trajetórias de vida, o que facilitaria seu processo de aprendizagem. As disciplinas foram divididas em grandes áreas: humanas (português, história, geografia e inglês), exatas (química, matemática e física) e ciências (ciências e biologia). Cada uma das áreas deveria ser assumida por um professor que possuísse licenciatura relacionada a alguma das disciplinas. A maioria dos professores procedia do quadro do magistério municipal, recrutada através de seleção interna. Para algumas das vagas não preenchidas, foram contratados professores via convênios. Os professores da área de qualificação eram todos contratados pelas entidades conveniadas, já atuavam nos cursos de qualificação e requalificação do DET.

A divisão da carga horária nas áreas foi definida de acordo com as necessidades de cada área profissional dos Centros Públicos, sendo preservada uma maior carga para as atividades relacionadas às disciplinas de português e matemática. Dessa maneira, no Centro Público Tamarutaca (depois Armando Mazzo), onde ocorria o ensino para a construção civil, a carga horária das aulas da área de exatas era maior que a dos outros Centros, pelas exigências do tipo de qualificação profissional a ser desenvolvido. Da mesma forma, no Centro Julio de Grammont a carga horária referente ao ensino de ciências era maior, por se tratar da área de estética.

Os itinerários formativos eram construídos, de acordo com o documento do DET, "Projeto de implantação de itinerário formativo", mencionado no primeiro capítulo (item 1.2.2), através de módulos seqüenciais, progressivos e flexíveis, que se propunham a respeitar o ritmo e o tempo disponível dos alunos para o aprendizado, e permitindo-lhes a construção de seu próprio itinerário.

Dessa maneira, os Centros Júlio de Grammont e Onze de Junho (depois Valdemar Mattei) organizaram, da seguinte maneira, os seus itinerários: 
Tabela 15 - Proposta de itinerário formativo CPFP Julio de Grammont 2003.

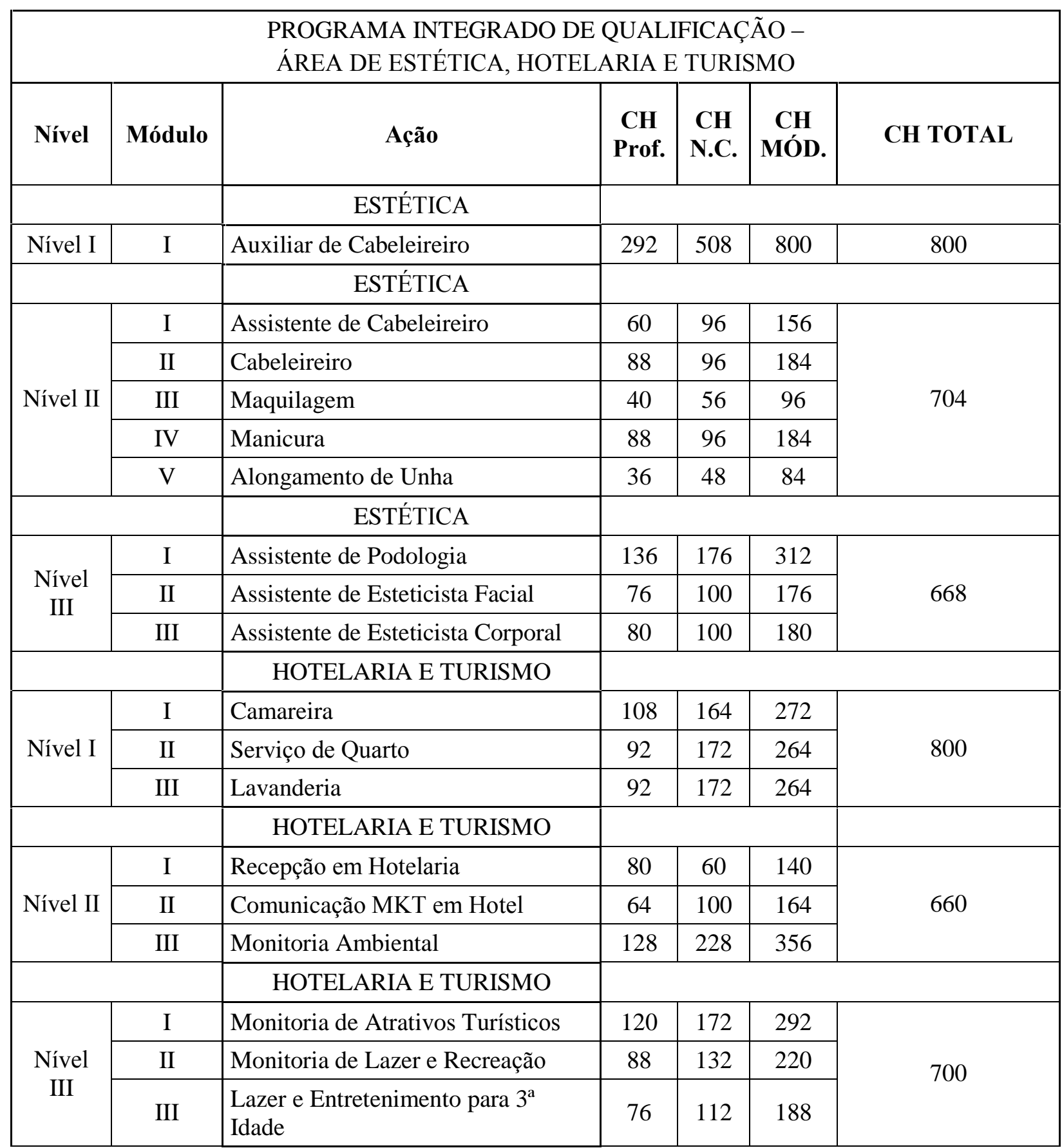

Fonte: CPFP Julio de Grammont.

CH Prof. - carga horária profissionalizante/ CH N.C. - carga horária núcleo comum. 
Tabela 16 - Proposta de itinerário formativo CPFP Onze de Junho 2003.

\begin{tabular}{|c|c|c|c|c|c|c|}
\hline \multicolumn{7}{|c|}{ PROGRAMA INTEGRADO DE QUALIFICAÇÃO - AREA DE INFORMÁTICA } \\
\hline \multirow[t]{2}{*}{ Nível } & Módulo & Ação & $\begin{array}{l}\mathrm{CH} \\
\mathrm{INF} \text {. }\end{array}$ & $\begin{array}{l}\mathrm{CH} \\
\text { N.C. }\end{array}$ & $\begin{array}{l}\text { CH } \\
\text { MÓD. }\end{array}$ & $\begin{array}{c}\mathrm{CH} \\
\text { TOTAL }\end{array}$ \\
\hline & & $\begin{array}{c}\text { Introdução às Técnicas de } \\
\text { Microinformática }\end{array}$ & & & & \\
\hline \multirow{3}{*}{ Nível I } & I & Introdução ao Mundo da Informática (PIQ) & 16 & 192 & 208 & \multirow{3}{*}{808} \\
\hline & II & Sistema Operacional I (PIQ) & 40 & 160 & 200 & \\
\hline & III & Sistema Operacional II (PIQ) & 124 & 276 & 400 & \\
\hline & & Técnicas de Microinformática & & & & \\
\hline \multirow{3}{*}{ Nível II } & I & Sistema Operacional (PIQ) & 120 & 120 & 240 & \multirow{3}{*}{708} \\
\hline & II & Editor de Textos com Internet & 120 & 120 & 240 & \\
\hline & III & Aplicativos & 114 & 114 & 228 & \\
\hline
\end{tabular}

Fonte: CPFP Onze de Junho.

A organização dos módulos deu-se somente na área da qualificação profissional. Os itinerários formativos foram divididos em módulos, com carga horária e processo de certificação previstos. As disciplinas do núcleo comum, embora formalmente organizadas de forma modular, na prática, sua oferta obedece ao critério convencional do ano letivo, dividido em bimestres letivos, o que trouxe dificuldades na realização do Programa.

Uma outra séria dificuldade observada e já apontada pelos participantes, diz respeito ao processo de planejamento/ definição dos cursos ou itinerários ocupacionais. Se uma das tarefas do Observatório consiste em levantar informações sobre as demandas econômicas locais, da cidade ou da região, para que sirvam de orientação na formulação de propostas de formação profissional, essas informações não chegam, efetivamente, às mãos de quem propõe os cursos. A orientação do DET aos núcleos pedagógicos dos Centros é a de que se baseiem na Classificação Brasileira de Ocupações - CBO.

Com exceção da $\mathrm{CBO}$, os procedimentos para a proposição dos cursos adquirem caráter diferenciado em cada um dos Centros Públicos. Dentro dos núcleos pedagógicos, os coordenadores das entidades parceiras têm um importante papel nessa definição, por apresentarem acúmulo dessa discussão. Seguem alguns relatos que auxiliam a explicitar esse processo: 
$\mathrm{Na}$ verdade, assim, eu quero enfatizar que apesar do DET estabelecer as diretrizes, a gente tem uma certa autonomia pra desenvolver isso, e quando eles querem puxar a discussão, eles não tem muito parâmetro pra propor, eles tem uns cursos, mas mesmo os cursos da CBO, sim mas o CBO ta atrasada já, as coisas estão evoluindo, então, neste ponto, ou por dificuldade deles de saber o que a gente desenvolve, acompanhar como a gente acha que eles deveriam acompanhar os cursos ou por até uma certa autonomia que eles nos delegam, a gente tem definido dentro dessa margem que eu te falei, de definir isso. O recurso é muito pequeno, então a gente não tem muito que pesquisar e não tem interlocutores pra pesquisar as mudanças que a gente gostaria. Então a gente define os cursos dentro da nossa capacidade de atendimento e dentro desse mosaico. [...] A gente buscou... essa é uma construção na verdade. A gente se orientou... há dois anos que eu estou aqui, a gente começou até juntos a fazer isso, a articulação veio ao tentar ver os atores, quais os atores contribuem para esse perfil, então a questão do mercado de trabalho, através da Relação Anual de Informações Sociais, $\mathrm{CBO}$, apesar da CBO sempre olhar pra trás, ela ta sempre olhando um contexto que está lá, e a dinâmica do mercado de trabalho ela é muito mais rápida, então você usa dois painéis, que é a CBO e a RAIS por um lado, e por outro lado você vai visitar, ou acompanha os cursos concorrentes e por outro lado você traz alguns profissionais que atuam na área pra definir um perfil. Esse ano, a gente implementou mais ainda a questão das empresas, então as empresas nos emprestam um pouco do know-how e um pouco da tecnologia, que eles estão na ponta, a gente não teria capital, recurso pra acompanhar isso [...] Então as empresas, ainda que isso seja muito difícil de articular com elas, elas nos emprestam essa tecnologia. E essa moeda de troca, ela é difícil de novo assim de você compor porque a empresa ela tem uma essência que é diferente da nossa, e as pessoas não entendem isso. (CORD3, 2006)

Olha, na real, eu acho que vai muito mais em cima do foco do instrutor do que propriamente de uma avaliação mais concreta do perfil. [...] Então quando isso (cursos livres) é transposto pro PIQ aí ta bom, onde é que a coisa pega? Com base em que a gente está trabalhando? Isso do ponto de vista da estruturação do curso. [...] mas a minha percepção é que normalmente a gente fazia em cima da percepção do instrutor, o instrutor "eu trabalhei isso, isso e isso, esse grupo vai continuar pra cá, aí então eu acho que tem que trabalhar isso, isso e isso" da lógica do instrutor. Um complicador que eu acho, e aí é assim eu tenho um olhar critico, um complicador que eu acho é que a gente também determina em cima, conversando com o instrutor e não necessariamente com quem contrata [...] $\mathrm{O}$ fato de não estar vinculada, essa área de serviços não estar vinculada a nenhuma indústria, nenhum setor produtivo mais... Tudo é muito autônomo nessas coisas. Então a gente encontra dificuldade, eu mesmo encontrava dificuldade de pensar um interlocutor pra fazer essa discussão, em que pese eu achar que sentia, em ver que eu tenho a falta, mas eu também não conseguia achar um interlocutor pra fazer essa discussão, e na verdade você fica meio que refém, entre aspas, dos instrutores e aí muitos deles não tem uma prática de salão (de beleza), por exemplo, ou salão não é o principal deles, então a escola é o principal deles, o salão às vezes algum até tem, mas como atividade secundária, então perde um pouco dessa dinâmica do que é o mercado de trabalho, então eu acho que tem um pouco desse problema, isso eu acho que é uma falha nossa. Por outro lado, você também não tem o Observatório pra te alimentar com dados. Então [...] a gente podia pegar lá a CBO olhar, ver, etc. teoricamente, lá nas descrições das competências, 
teoricamente, aquilo lá talvez tenha tido mesmo a participação dos segmentos, mas será que sim, será que não, e também por que na verdade como o próprio Departamento, ele também não tem então [...] o DGTR que permitisse minimamente uma base pra você construir um pouco essa questão. (CORD1, 2006)

[...] é feito pelo conjunto de professores, não só com relação à informática, mais com o professor de informática, ...Não só eles. Começa com eles, mas isso tem que subir ate a própria Secretaria de Educação. A gente tem a prática de começar e a partir do que a gente percebe, a gente vai retornando até a Secretaria de Educação. E aí são definidos os cursos. Mas hoje em dia, eu creio que o Centro Público tem tido a primazia de definir o itinerário... (CORD2, 2006)

A gente fez entrevista com profissionais da área, a gente foi atrás da Central de Autônomos para eles indicarem qual a demanda tem no mercado, a gente foi pra $\mathrm{CBO}$, enfim a gente fez uma série de pesquisas, tentamos entrar em contato com os sindicatos, acaba sendo uma ação de cada Centro. (AP3, 2007)

Depois de 2004, algumas características do Programa se alteraram. Durante esse ano, a principal modificação foi a nova divisão das disciplinas do núcleo comum. Cada professor assumiu duas disciplinas afins (história e geografia, matemática e física, português e inglês, biologia e química), diferente das grandes áreas com que estavam trabalhando até então.

Essa nova divisão se deu em virtude da avaliação do Programa realizada ao final do ano, onde os professores apontaram tanto a necessidade de maior divisão entre as áreas, quanto a de estender o tempo de duração do PIQ II para dois anos, ou, pelo menos, para um ano e meio. Em relação às propostas de itinerário, as mudanças que ocorreram foram de adaptação entre carga horária e conteúdo, principalmente nos módulos iniciais, uma vez que os professores da área técnica avaliaram que os módulos propostos nos cursos livres de qualificação e requalificação não se aplicavam exatamente ao PIQ no que se refere a carga horária. Neste, os alunos apresentavam um ritmo diferenciado, o que demandava maior carga horária para sua execução.

No ano de 2005, não ocorreram grandes alterações pedagógicas. Houve uma reorganização nos quadros de coordenação pedagógica no DET, e a aprovação da "Lei do PIQ", que trata basicamente do terceiro eixo político do Programa, a "monitoria social". Um fato importante foi o crescimento de mais de $170 \%$ no atendimento de alunos e a necessidade de maior contratação de professores para atendimento da demanda.

A partir de 2006, configuram-se mudanças estruturais: a autorização do PIQ pelo Conselho Municipal de Educação e a nova orientação da organização dos cursos, rompendo com a proposta de itinerário formativo dentro do Programa. 
Através do Parecer 02/2006, o Conselho Municipal de Educação autorizou o funcionamento do PIQ que, no documento, consta como Cursos de Ensino Fundamental de Formação Inicial e Continuada de trabalhadores.

Fundamenta-se no Parágrafo $2^{\circ}$ do Artigo 36 e nos Artigos 36 a 41 da Lei de Diretrizes e Bases. O artigo 36 da LDB trata do currículo do ensino médio, e, segundo o seu parágrafo $2^{\circ}$, “o ensino médio, atendida a formação geral do educando, poderá prepará-lo para o exercício de profissões técnicas". Os Artigos 37 a 38 dispõem sobre a Educação de Jovens e Adultos, e os Artigos 39 a 41, sobre a Educação Profissional. O inciso I do art $1^{\circ}$ do Decreto 5154/04 atribui nova denominação à educação profissional básica, passando a chamá-la formação inicial e continuada de trabalhadores.

Este Parecer é bastante interessante, no sentido de levantar duas questões centrais. A primeira sustenta-se, em parte, na legislação que trata do ensino médio, sendo que este nível da educação não é de responsabilidade do poder público municipal e o processo de autorização trata de cursos de ensino fundamental de formação inicial e continuada. Seria interessante investigar se a intenção de se referir ao ensino médio está na direção de uma futura aprovação por parte do Conselho, para funcionamento do PIQ III.

Segundo, ele formaliza o Programa, sem considerar em nenhum momento, o Parecer 11/2000 do Conselho Nacional de Educação e a Resolução 1/2000 que estabelecem as Diretrizes Curriculares Nacionais para a Educação de Jovens e Adultos. Neste parecer e na resolução estão presentes as considerações referentes a organização própria da EJA, respeitando sua identidade, com modelos pedagógicos próprios, conforme o Artigo $5^{\circ}$ da Resolução 1/2000.

Art. $5^{\circ}$ Os componentes curriculares conseqüentes ao modelo pedagógico próprio da Educação de Jovens e Adultos e expressos nas propostas pedagógicas das unidades educacionais obedecerão aos princípios, aos objetivos e às diretrizes curriculares tais como formulados no Parecer CNE/CEB 11/2000, que acompanha a presente Resolução, nos pareceres CNE/CEB 4/98, CNE/CEB 15/98 e CNE/CEB 16/99, suas respectivas resoluções e as orientações próprias dos sistemas de ensino.

Parágrafo único. Como modalidade destas etapas da Educação Básica, a identidade própria da Educação de Jovens e Adultos considerará as situações, os perfis dos estudantes, as faixas etárias e se pautará pelos princípios de eqüidade, diferença e proporcionalidade na apropriação e contextualização das diretrizes curriculares nacionais e na proposição de um modelo pedagógico próprio, de modo a assegurar:

I - quanto à eqüidade, a distribuição específica dos componentes curriculares a fim de propiciar um patamar igualitário de formação e restabelecer a igualdade de direitos e de oportunidades face ao direito à educação; 
II- quanto à diferença, a identificação e o reconhecimento da alteridade própria e inseparável dos jovens e dos adultos em seu processo formativo, da valorização do mérito de cada qual e do desenvolvimento de seus conhecimentos e valores;

III - quanto à proporcionalidade, a disposição e alocação adequadas dos componentes curriculares face às necessidades próprias da Educação de Jovens e Adultos com espaços e tempos nos quais as práticas pedagógicas assegurem aos seus estudantes identidade formativa comum aos demais participantes da escolarização básica.

Dessa maneira, tanto o Parecer 11/200, quanto a Resolução 1/2000 e o Decreto 5154/04 estabeleceriam uma base legal para a construção de uma proposta alternativa que atendesse melhor às necessidades do PIQ. No entanto, em seu item 3, a proposta de autorização, solicitada pela Secretaria de Educação, reproduz a estrutura do ensino regular, considerando, como adequação, a redução da hora aula:

Além disso, a interessada faz uma adequação das horas- aula aos períodos dos cursos: nos períodos diurnos, horas- aula de 50 (cinqüenta) minutos e no período noturno, horas- aula de 40 (quarenta) minutos adequando assim, à realidade do aluno jovem e adulto trabalhador.

Outro item, aparentemente responsável pela desestruturação da oferta dos itinerários formativos, foi o de número 6 , que introduziu a informática na carga horária da parte diversificada:

A ênfase à INFORMÁTICA (grifo do autor) como parte diversificada, atende a proposta das Diretrizes Curriculares Nacionais quanto a currículos específicos e propostas pedagógicas das escolas que sejam de interesse de suas comunidades;

Foi esta medida a responsável pela introdução da informática nos ciclos do PIQ II, deslocando apenas para o PIQ III a qualificação profissional e retirando do Programa a possibilidade de o aluno cursar um itinerário formativo que, mesmo não atendendo a todas as premissas colocadas, possibilitava-lhe seguir um determinado percurso dentro de uma trajetória profissional ou ocupacional. A informática, neste caso, tinha o objetivo da inclusão digital, e não da qualificação profissional.

Além disso, a partir da autorização do PIQ, o período de matrículas se estendeu até o dia 30 de setembro no ano letivo, permitindo que o aluno iniciasse sua freqüência no curso a qualquer momento. Se isso, por um lado, auxilia o trabalhador no acesso à escola, por outro, 
não era compatível com a estrutura de cursos profissionalizantes oferecidos, os quais apresentavam, até então, uma carga horária que variava de 180 a 320 horas ano.

A proposta de organização do curso em módulos flexíveis, que possuíssem terminalidade, e possibilitassem a escolha e construção de um itinerário por parte do aluno, não se realizou no PIQ, e ocorreu muito parcialmente nos itinerários de cursos livres. Dessa maneira, um curso de elétrica, por exemplo, não poderia mais oferecer a possibilidade de modularização com terminalidade, uma vez que a estrutura modular pressupunha o cumprimento de pré-requisitos para realizar um módulo seqüencial mais adiantado. Isso quer dizer que um aluno que entrasse no curso em setembro, caso não apresentasse conhecimentos anteriores na área, não apresentaria os pré-requisitos para continuidade do curso, por não ter cursado os primeiros módulos. Este problema aconteceu em 2007 e está acontecendo nos PIQ's II, em 2008, uma vez que os cursos profissionalizantes voltaram para o PIQ II em função da não oferta de PIQ III para a comunidade, ficando este restrito somente aos alunos oriundos do PIQ II Final.

A introdução da informática parece estar mais vinculada a uma questão legal no que toca à prestação das contas do DET do que a uma opção pedagógica. O ensino de informática, na perspectiva da inclusão digital, não caracteriza qualificação profissional, o que não traria problemas com o Tribunal de Contas. Outra justificativa possível para esta decisão seria a ausência de verbas para a manutenção dos cursos, principalmente para a compra de material. Esta foi uma situação bastante recorrente, a partir de 2006, na maior parte dos Centros Públicos.

Com o retorno da qualificação profissional no PIQ II, houve, neste novo modelo institucional, uma redução de 50\% em sua carga horária. No modelo anterior, os cursos eram ofertados dois dias por semana, e, a partir da autorização do Programa, de modo a atender a carga horária da base comum que a legislação determina, a qualificação passou a ser oferecida uma vez por semana. Se antes a modularização era difícil, torna-se, desta maneira, quase impraticável. A avaliação de que os cursos profissionalizantes oferecidos uma vez por semana não apresentam resultados positivos, já havia sido feita em 2002, na suplência profissionalizante. O resultado dessa avaliação foi justamente o novo desenho que a suplência assumiu, que deu origem ao PIQ. Dessa maneira o Programa volta a um desenho anterior, que já se mostrou deficiente. 
Como a proposta da pesquisa é a de abarcar o período entre 2003 e 2005, muitos dados relativos a 2007 não foram levantados. Por esta razão, não há como apresentar as cargas horárias dos "itinerários" oferecidos em 2007. Entretanto, a fm de dimensionar o problema, é importante observar que se, em 2004, um aluno ingressasse no PIQ I e levasse o tempo de um ano para cada ciclo (com o PIQ II oferecido em dois ciclos), em quatro anos de permanência ele teria uma carga horária de formação profissional em torno de 1200 horas, o que equivale à carga horária do ensino técnico. No desenho existente hoje, onde ele inicia a formação profissional no PIQ II Inicial e conclui no PIQ III, ele terá aproximadamente 540 horas. Desta maneira, sofrerá um grande prejuízo na sua formação/ qualificação profissional.

Desde o desenho inicial, o Programa apresentou problemas no que se relaciona à oferta de itinerários formativos. O primeiro era justamente o não reconhecimento, por parte de outras entidades, da qualificação oferecida, o não reconhecimento dos créditos obtidos para a continuidade dos estudos. Outro problema dizia respeito à perspectiva de o aluno poder formar o seu próprio itinerário, optando por módulos que julgasse importantes para o seu percurso, o que, com algumas raras exceções, não ocorreu. Esta última dificuldade foi apontada nas entrevistas de AP3 e de DET2, anteriormente citadas:

\begin{abstract}
Hoje eu estou chegando a essa conclusão. Não porque não se tem o tempo, certo, mesmo o Programa tendo, seria um dos objetivos dar a base e dar condições para que o trabalhador fosse buscar fora a continuidade desse aprimoramento, mas a gente sabe que não funciona desse jeito. A gente não conseguiu atingir um dos objetivos. No início, lá atrás, a gente lembra que uma das coisas que a gente acreditou bastante era dar condições para que o aluno que passasse por aqui, ele tivesse instrumentos para aprofundar suas questões e hoje eu acho que a gente não atinge esse objetivo. Hoje eu acho que todo o Programa deixa muito a desejar nesse sentido [...] A intenção do itinerário no PIQ era a de estar dando condições, dando conteúdos, dando conhecimento, onde o aluno ia construindo seu conhecimento frente a uma profissão. Então, através de módulos, o aluno ia passando, construindo aquilo que tivesse na intenção dele, na vontade dele. Hoje, nós não conseguimos aplicar aquilo que a gente pensava, acho que tem um itinerário, mas um itinerário mais direcionado da gente, de conteúdos, de forma que a coordenação, o corpo pedagógico acha. Acho que nesse sentido também deixou a desejar em muitos sentidos. (DET2, 2007)
\end{abstract}

Apesar das alterações existentes no Programa, os dados de evasão parecem não refletir os seus problemas, como pode ser observado. 
Tabela 17 - Evasão no período de 2004 a 2006 (em porcentagem).

\begin{tabular}{|l|c|c|c|c|}
\hline \multicolumn{1}{|c|}{ Unidade } & $\mathbf{2 0 0 3}$ & $\mathbf{2 0 0 4}$ & $\mathbf{2 0 0 5}$ & $\mathbf{2 0 0 6}$ \\
\hline $\begin{array}{l}\text { Júlio de } \\
\text { Grammont }\end{array}$ & - & 58,0 & 43,5 & 29,6 \\
\hline Valdemar Mattei & - & 61,0 & 50,3 & 36,7 \\
\hline Armando Mazzo & - & 77,0 & 65,4 & 43,0 \\
\hline Média & - & 65,3 & 53,0 & 36,4 \\
\hline
\end{tabular}

Fonte: Observatório da Educação e do Trabalho DET/SEFP.

Obs.: Não foram conseguidos os dados de 2003.

Os dados mostram uma queda tendencial da evasão Seria necessário verificar como foram realizados os cálculos de evasão em 2006, uma vez que a partir deste ano a matrícula de alunos ocorreu até o mês de setembro, diferentemente dos anos anteriores, em que os alunos ingressavam no Programa até o final de fevereiro. Seria interessante levantar os dados de 2007, a fim de se perceber o quanto a readequação ocorrida em 2006 teria afetado ou não essa variável. No entanto, é preciso considerar que a alteração nas configurações do Programa se deu mais no campo da qualificação, e que o campo da educação escolar tenha se estabelecido de maneira mais permanente . Este aspecto deve estar relacionado ao motivo de os alunos escolherem os Centros Públicos para realizar os seus cursos. Conforme suas diretoras, o que movia a maior parte dos alunos a priorizar os Centros era a busca pela elevação de escolaridade:

Eu acho que metade do público vem pela elevação da escolaridade, acho que está muito dividido isso, e metade vem pela profissionalização e ao se deparar com a profissionalização a grande maioria até que veio pela elevação, acaba vendo que tem perfil pra essa [...] Como tem o processo inverso, não quero e não quero mesmo, não gosto, mas eu acho que é muito mais, chega ao final do ano conjugando as duas coisas, mesmo vindo pela elevação ou pela qualificação, do que propriamente só elevação. Eu acho que no final de tudo a gente consegue. (DIR1,2006)

Não, eu vejo como o nosso aluno vem, isso mais no PIQ III, eu vejo que o PIQ III, ele vem porque ele busca as duas coisas. O PIQ II, como é um público mais jovem, eu vejo porque ele vem só pra buscar a certificação (escolar) [...] E nem sempre ele consegue ficar até o fim do Programa. Porque existe também uma exigência do aluno, para com o aluno. Não dá pra levar de qualquer jeito. Então, eu vejo que o pessoal, o adulto, digamos assim, o adulto, ele vem em busca das duas coisas, vem em busca das duas coisas e quer dar continuidade nos outros cursos. Agora, o jovem, ele vem só pra se certificar no Ensino Fundamental. E aí, existe uma evasão muito maior do Ensino Fundamental do que no PIQ III. (DIR3, 2006)

Eu penso que no Centro Público, apesar de eu estar há um pouco mais de um ano apenas, é a maioria. Eu acho que setenta por cento dos alunos vêm 
buscar ainda o avanço da escolaridade. Eles encontram a informática na escola e aí acabam buscando até oficinas livres, que são oferecidas na escola, em período contrário. Então, depois que eles encontraram, na hora que eles vieram buscar o avanço da escolaridade, é que eles vêm buscar a qualificação profissional e acabam buscando o período contrário. Outros que estão aqui, outros trinta por cento, já vieram buscar, então eles fazem oficinas livres, eles buscam o ensino médio com a qualificação, e eles vêm buscar essa qualificação porque a informática hoje, apesar dela estar tão difundida, apesar dela estar ganhando mercado, ainda tem nichos, então eles vêm buscar pra se encaixar nesses nichos do mercado. (DIR2, 2006)

As entrevistas mostram que há diferentes interesses por parte dos alunos. Há diferentes faixas estarias que são atendidas pelo Programa, e valeria a pena pensar em como atender a estas diferentes demandas.

A partir desses relatos, se essas impressões se confirmarem na realidade, é provável que as alterações no campo da qualificação profissional dentro do Programa não afetem a escolha e permanência do aluno no curso. E se a expectativa dos alunos for a de certificar a elevação de escolaridade, é compreensível que os índices de evasão tendam a diminuir, já que o Programa se direciona cada vez mais para isso.

No ano de 2004, por iniciativa da coordenação pedagógica da época, o assessor que estava atuando junto à formação do quadro realizou uma pesquisa juntamente com a equipe a fim de levantar, entre os alunos, qual a proporção de interessados na elevação de escolaridade e/ou no ensino integrado. $\mathrm{O}$ resultado da pesquisa mostrou que praticamente $50 \%$ dos alunos escolhiam o Programa, atraídos por sua proposta de integração da qualificação à educação básica, e $50 \%$ o procuravam somente pela certificação da escolaridade. As falas das diretoras indicam que a situação, hoje, não apresenta muita alteração.

Uma outra avaliação feita pela equipe indica que esse suposto desinteresse pela qualificação profissional pode estar relacionado ao fato de a oferta dos cursos ser centralizada. Desta maneira, os alunos precisam se deslocar até o Centro Público que oferece o curso de seu interesse, ou realizar a opção o que o Centro que lhe é mais próximo oferece. A Secretaria de Educação disponibiliza um ônibus para o percurso entre os Centros, mas, muitas vezes, o seu horário não é compatível com o horário de trabalho dos alunos. Para muitos deles, de fato, qualquer mudança no que diz respeito à oferta da qualificação na área respectiva do Centro Público, que não é sua primeira escolha, não fará diferença. Outras vezes, os alunos optam por não realizar a qualificação:

Os alunos procuram por proximidade e aí que nos preocupa, porque o ano que vem nesse projeto que nós bolamos, esse aluno do PIQ vai fazer perto da 
casa dele, não porque ele queira, mas porque é perto da casa dele. Pelo menos a gente tinha um curso de pequenos reparos, estou falando mais na área masculina que pequenos reparos a gente direcionava mais um pouco, e foi interessante. [...] este ano não, não temos perspectiva nenhuma, não é preconceito, não é que homem não pode ser cabeleireiro, a questão não é essa, eles não querem sair da escola, mas não querem fazer estética. (AP1, 2006)

Um outro fator que talvez colabore para esse desinteresse consiste em que a pretendida relação entre a qualificação e o conhecimento científico e técnico não foi um dos objetivos alcançados. Esse movimento que ocorreu nos primeiros anos foi, aos poucos, se extinguindo, como conseqüência das deficiências estruturais do Programa.

Como já foi mencionado, um dos sérios problemas do Programa é o de não viabilizar uma estrutura compatível com este objetivo. A ausência de recursos financeiros se expressa tanto na forma de contratação dos professores, quanto na distribuição de sua carga horária de trabalho. A necessidade inerente ao trabalho pedagógico de propiciar espaços e tempos para discussão coletiva de seus objetivos, para o planejamento da ação também não é atendida. A racionalização e otimização de seu quadro de pessoal significa uma extensa jornada de aulas e um reduzido horário de tempo de trabalho pedagógico para os professores, das chamadas horas atividade. Nesse sentido, além de o professor ter um acúmulo de tarefas para um horário reduzido, a fragmentação dos horários impede tempos coletivos de organização do trabalho. Essa é uma queixa recorrente entre a equipe:

E em relação à questão pedagógica propriamente dita, você vê que você perde muito porque não tem a questão da hora atividade, principalmente dos professores conveniados, da rede a gente consegue garantir algumas coisas, pelo menos cinco horas atividade e os professores da ONG não. A determinação do DET é que é bem menos tempo que isso, duas horas no máximo, e isso faz com que você não tenha tempo para planejar, que esse professor também não tenha tempo para planejar, você não consegue sentar com o professor do específico, tanto que assim, toda aquela articulação que a gente conseguia desenvolver em 2003, 2004, em 2005 a gente começou a perder. Então, hoje, na realidade, o que acontece, o PIQ, na proposta lá do início, ela deixa de existir, porque você acaba tendo dois cursos: um curso específico e um curso fundamental ou médio, porque o que acaba acontecendo, com o número de hora atividade você não consegue fazer essa articulação, consegue assim, se algum professor tem algum conhecimento daquela área específica, e ele por iniciativa dele consegue estar fazendo o trabalho. (AP3, 2007)

Eu, assim, a minha avaliação muito fria deste último ano que vou utilizar, eu acho que a gente teve pouco tempo para a interdisciplinaridade entre as áreas. Eu tenho isso muito claro, é observado dentro deste Centro. Pra se ter realmente uma junção com maior aproveitamento, a gente tem que reestruturar um pouco a questão de hora atividade, a necessidade da 
interdisciplinaridade, os professores do núcleo comum poderem sentar e planejar junto com os professores do específico, da profissionalização, pra que realmente seja um programa totalmente integrado. Então eu senti este ano um distanciamento até por questões de não ter tempo hábil de planejamento com as duas partes envolvidas, então ficou uma coisa meio estanque, meio separada. (DIR1, 2006)

Se nós fôssemos ver pelo número de horas de contato que temos com os professores, não iríamos fazer nada. Porque não existe. Nos não temos reuniões, como já tivemos com outras áreas para a troca de informação, planejar juntos. Geralmente, as horas atividades são separadas, e acabamos ficando separados uns dos outros, e isso não contribui muito. Mas tem professores com muita boa vontade. Eu, por exemplo. com vários professores tenho um bom relacionamento, na hora do intervalo no corredor e na sala dos professores. Incrível. Nós criamos esse ano muitas coisas, apresentação de alunos, fizemos textos e joguinhos no computador e depois imprimimos. Mas não que exista momentos para criarmos estrutura para isso. Fica na boa vontade de cada professor mesmo. As APS acabam ajudando muito também, acabam trabalhando com a gente. (Dalva, 2006)

Com os professores do núcleo comum a gente não está tendo essa oportunidade, como a gente tinha. Devido aos horários, está meio diversificado, então tem professor que trabalha aqui, dá aula, depois ele tem outra escola para dar aula e, às vezes, a gente nem se encontra, cruza pelo corredor [...] então quando tem alguma coisinha para dizer é pelos corredores, até isso, até para a nossa comunicação está difícil para organizar. (Marina, 2007)

Esse ano em nenhum momento, assim, só na... Tem professor que eu não vi, esse ano inteiro tem professor que eu não sentei nenhuma vez. Agora [...] a gente pelo menos tenta assim, antes do horário sentar todo mundo, mas mesmo assim tem professor que eu nunca... Não consegui sentar nenhuma vez. Então é na hora do intervalo, é rapidinho, é quando tem algum projeto que a escola vai trabalhar, e quando tem a Semana do Centro que aí você é obrigado... (Gisela, 2006)

Outra reivindicação da equipe diz respeito à existência de espaços para discussões coletivas, onde problemas, orientações, perspectivas possam ser colocados e partilhados, onde as dificuldades sejam superadas coletivamente. Há a constatação de que a participação nos rumos do PIQ e a discussão pedagógica ampliada são exigências que não vêm sendo atendidas

[...] na formação ficou a desejar, dos professores, e assim a gente foi no ensaio e erro, e acho isso muito ruim. Mas tivemos grandes ganhos mais pela equipe, pelo núcleo, porque depender de, não tivemos especialistas, não tivemos discussões com o Departamento, não tivemos respaldo nenhum, era salve-se quem puder, façam do jeito que vocês acharem, tem que cumprir isso e isso é muito triste. De quando a gente começou a discutir essa escolaridade e fazer, em conjunto, essa profissionalização, era difícil pra gente comungar essas duas coisas, e hoje é difícil porque as coisas estão evoluindo e a gente precisa saber o que está aí e não tínhamos condições de, 
então a gente busca entre a gente e individualmente, e a gente perde quando faz isso no individual, porque no coletivo a gente ganha muito, eu acredito em fazer as coisas no coletivo. (AP1, 2006)

Quanto ao pedagógico, ajuda pedagógica, esse ano foi um pouco comprometida pelas mudanças que teve, a gente teve grandes mudanças aqui e o nosso colega que vem nos dar suporte pedagógico, dentro das técnicas do específico, não tem nenhum conhecimento, só tem o conhecimento da escrita, de como desenvolve um aluno dentro da sala de aula, esse suporte a gente tem, mas do conhecimento que a gente mostrou aí, junto com outros, depois vai embora, vem novos, aí começa tudo de novo da estaca zero. (Marina, 2007)

Eu sinto falta nesse sentido das reuniões que tínhamos, algumas formações, dinâmicas que ajudavam bastante no terceiro eixo perspectiva políticaideológica. Tivemos mais reuniões pedagógicas, algumas formações. E isso prejudica principalmente para mim que sou mais técnica, acaba não auxiliando tanto e precisaria ser com mais freqüência. Eu busco mais formação por mim própria. Eu tento nas horas-atividade que também são poucas, estudar um pouco. (Dalva, 2006)

[...] se resume na vontade das pessoas, as pessoas tem que ir atrás, as pessoas que fazem um movimento para isso, mas não que se propicie momentos de discussão ou que as pessoas participem da elaboração. Teve um momento em 2005 que nós colocamos algumas questões, mas muitas delas não foram acatadas, não foram consideradas e mesmo assim só tinha AP e diretora. [...] não tem um momento pensado para isso [...] sempre teve momentos em que as pessoas se colocavam, falavam. Hoje, todo final de ano, se tem uma avaliação escrita, mas a gente não tem retorno disso. (AP3, 2007)

A gente acabou perdendo este ano também aquela coisa que a gente chamava de fórum pedagógico. Acho que a gente teve um ou dois, se não me engano, acho que a gente perdeu e acho que a gente tem que ter sim até pra que um aprenda com o outro porque todo mundo tem coisas boas e interessantes pra contribuir e enxertar dentro de cada Centro [...] não só eu mas como toda a equipe pedagógica que compõe. Uma outra coisa que eu acho que a gente tem que retomar é a discussão e formação coletiva com esses professores [...] eu acho que se a gente tivesse oportunidade de ter reuniões coletivas onde todo mundo que faz parte do Programa discutisse mesmo tendo as desavenças, visões, como vou dizer? Iguais, mas assim, saber o que o outro pensa contribui pro Programa e o Programa só se fortalece, só cria raiz quando todo mundo comunga, mesmo com algumas divergências as idéias são coletivas, então eu penso nesse sentido. Eu sinto dentro da coordenação, dentro da direção do Programa, essa falta desses espaços coletivos onde se comungue o mesmo Programa e articule esse Programa. (DIR1, 2006)

E mesmo porque os professores pedem, eu acho que eles sentem necessidade dessa grande formação, de se sentar todo mundo junto e pensar todo mundo junto. Eu acho que, assim, nas dificuldades que a gente se encontra hoje, a gente caminhou, nós caminhamos. [...] E isso precisa, precisa parada, precisa repensar, que é uma das grandes dificuldades, e que eu percebo que, na avaliação que nós fizemos com eles, eles pedem isso. Então, eles sentem necessidade dessa parada. Desse momento. Não só no Centro, articular com os demais Centros também. Aqui e com os outros Centros. (DIR3, 2006) 
Diante do que foi apresentado até aqui, é interessante expor alguns ponto de vista sobre o PIQ, tanto no que diz respeito às críticas pertinentes quanto às propostas visando superar alguns de seus problemas.

As falas, como se viu, apontam para a importância e necessidade da relação entre trabalho e educação. Sobre os problemas e dificuldades a esse respeito, consideram:

Hoje, se a gente for pegar, esse ano que passou, eu acho que nós deixamos muito a desejar na qualificação profissional. Por mais que a gente tenha investido, houve uma organização da própria equipe de buscar recursos materiais pra poder implementar a qualificação profissional. [...] Eu acho que se for feita a qualificação profissional onde o trabalhador perceba a importância disso enquanto conhecimento e instrumento pra enfrentar a vida do dia a dia, essa vontade do trabalhador, do adulto estudar aumenta, permanece, é uma coisa que estimula ele a ficar em sala de aula e dar continuidade aos estudos. Eu acho que isso é fundamental. Se a gente pegar o SEJA, desde que eu entrei aqui na prefeitura o SEJA sempre foi um programa que tinha uma alto índice de evasão [...] mas se eu pegar os índices de evasão e o programa, o próprio adulto está falando, é um programa que não funciona muito bem pra gente e quando a gente pegava os dados da qualificação profissional pensava, o que ocorre nisso? O trabalhador também faz um curso, faz outro, mas ele percebe que ajuda, mas não resolve o problema e acho que a grande sacada foi atrelar essas duas coisas e colocar em um programa. (DET2, 2007)

[...] quando você começa a passar pra $5^{\mathrm{a}}$ a $8^{\mathrm{a}}$, que você começa a ter áreas especificas do conhecimento que você tem toda uma tradição curricular, aí, acho que isso traz um desafio, uma dificuldade de você organizar os cursos de EJA. Um dos elementos que eu acho de fato podem auxiliar muito é a questão do mundo do trabalho, a questão do trabalho, então eu acho que o PIQ, ele se insere, um pouco nessa lógica, de você estabelecer uma relação entre a educação e o trabalho, porque eu acho que é uma coisa que está colocada no geral, agora eu acho que ele padece, na forma que ele foi estruturado, aprovado na Câmara, aquela coisera toda, em que pese esta intencionalidade, ele submete essa experimentação à lógica e organização do tempo escolar. E isso eu acho que é um problema, eu sou muito critico com relação a essa questão do tempo na escola pra adulto, e eu acho que teoricamente ele caminharia um pouco por aí, acho também que ele teria a intencionalidade de fazer uma formação profissional, pra que o aluno além da educação saísse profissional de alguma coisa. Eu acho que ele não conseguiu fazer isso, e na verdade eu tenho dúvidas que isso é possível, no tempo que se tem eu acho que é viável por exemplo, quando você tem alguém, e aí que eu acho que tem a importância de você trabalhar um processo anterior, que é aquela coisa, se o cara é auxiliar de pedreiro durante um certo tempo ele acumula algumas coisas e aí ele passa a ser pedreiro, acumula outras coisas, e depois quando ele entra e você começa a [...] você consegue formatar um profissional, agora quando o cara entra como auxiliar de pedreiro pra fazer um curso, você vai dar um curso pra ele que depois vai desembocar em estética ou vai desembocar... aí fica difícil, então, e por outro lado, se você não tiver isso, numa perspectiva de política de emprego, se você se propõe a fazer isso, é um tiro no pé, por que não vai rolar, eu acho que tem um pouco isso, acho que se propõe a fazer isso, se propõe aquilo 
outro, aquilo outro, mas o que se percebe é que não não faz formação profissional [...] acho que dá minimamente um curso, uma educação escolar melhorada, com um pouquinho mais de dignidade vamos dizer assim, acho que não avança muito mais que isso, não sei, não sei se eu também estou sendo muito azedo [...] mas eu vejo que é um pouco isso, a perspectiva que eles colocaram acho que com certeza nas intenções não é nada disso, é uma coisa maravilhosa, mas eu acho que já nasceu complicado, você ter uma organização semestral, anual, acho isso complicadésimo, pra adulto, você perde gente no meio do caminho mesmo, se era pra fazer poderia ser mais ousado, eu sempre falei isso, eu acho que poderia ser mais ousado nessa questão da organização do tempo, eu acho que teria condição pra fazer, eu acho que teria condição pra ousar, tem uma estrutura na questão dos Centro Públicos que permitiria essa ousadia.

[...] então, por exemplo, o processo de formação é um processo que é centralizado a partir de uma lógica da educação, e uma lógica muito desfocada do que é essa relação com o trabalho, eu pessoalmente acho, aquelas discussões de colocar os professores de português na sala, os professores de história na sala, pra discutir currículos e conteúdos, eu acho uma bobagem, por que é assim, se tem um eixo, ou você tem uma proposta ou você não tem, então eu acho que a proposta curricular ela não é dos professores, ela é uma proposta política que é construída pela sociedade, pela comunidade, então tem que vir essa orientação, e aí, é claro, essa orientação não é um pacote fechado, mas parte de quem... agora pra isso precisa saber o que quer, [...] então, a gestão passa a ser da educação e aí o caráter escolar volta, aquela coisa que é a estrutura puxa tudo de novo então. E aí os professores estão nessa situação, eu acho que ouve um retrocesso do ponto de vista de vários deles. [...] fica tudo meio que no piloto automático, transformações que eles tinham por área, por que é assim, não é uma equipe, a gente tem uma avaliação que ouve um retrocesso, e tem tido dificuldade de discutir com os professores algumas questões, por que eles estão na visão escolarizada mesmo, por quê? Pela própria gestão do Programa tem fortalecido essa visão, empurra pra isso, então fica difícil.

[...] então eu sinto, acho que muito essa questão da organização do tempo da escola pro adulto, acho que é muito complicado, porque eu acho que acaba sendo meio que o pontapé inicial, por que pelo que eu vejo do ponto de vista dos professores, é onde eles têm maior resistência, e aquilo dificulta você saber, por exemplo, onde é que começa matemática onde é que termina, onde é que vai começar a história, onde é que vai terminar a física, porque na verdade cada um está vendo lá o seu pedacinho, e não vê o seu pedacinho enquanto área do conhecimento que possa dialogar com o outro, mas está vendo a sua hora/aula, a sua remuneração, então acho que esse é o grande problema, então eu acho que a questão de você romper com a lógica da educação escolar do ponto de vista da estrutura das áreas do conhecimento, eu acho que é uma coisa mais tranqüila, [...] mas o que eu acho que entrava nesse sentido é você ainda ter impregnado essa questão da estrutura e da cultura escolar ali, da hora/aula, dos limites da disciplina, principalmente de $5^{\mathrm{a}}$ a $8^{\mathrm{a}}$, isso eu acho complicado, acho complicado você ter uma organização semestral ou anual pra aluno adulto, então, [...] a questão de evasão ah, nós não perdemos aluno, é que ele trabalha, falar que um adulto trabalha é a mesma coisa que falar que uma criança respira, é a mesma coisa faz parte [...] então porque você vai falar que o trabalho é um impeditivo, então, na verdade, você é que tem que organizar o tempo, não em função da sua jornada de trabalho, mas em função do aluno, porque ele é diferenciado nesse sentido, agora eu acho que tem um problema do ponto de vista da regulação [...] você tem que ter um sistema que banque isso, e aí essa é uma 
outra discussão, eu acho que o grande problema, o grande nó é a organização do tempo na escola para o adulto que não cabe a carga horária, não cabe uma série de coisas .

Até agora você reúne os professores de história, de geografia e etc., não tem nenhum momento que você reuniu os professores dos específicos, não precisa discutir a área do especifico, mas o que se quer com a formação profissional, a qualificação, e aí questões gerais do trabalho, ou a própria questão do plano de curso, por que pelo que eu ouço é comum entre todos os instrutores, então existe uma coisa que é comum a eles que pode ser trabalhado, já que a gente está querendo fazer por área, mas nunca juntou esse povo. Entendeu?

No PIQ, eu acho que essa relação com o trabalho do ponto de vista de dar elementos pra que esse aluno trabalhador, ele possa de fato pensar numa continuidade de estudos e aí pensar num itinerário formativo do ponto de vista da qualificação profissional, ele saber que ele pode fazer um curso técnico, que isso é uma alternativa viável, possível, que existe uma rede pública que oferece isso [...] acho que essa questão é uma questão importante. Acho que a outra questão é estabelecer qual é a relação que o trabalho, que a qualificação profissional deve ter, dentro dessa perspectiva mais ampla.. Até que ponto a organização do mundo do trabalho nos cursos do PIQ e aí considerando tudo, tanto a questão da formação nas especificas quanto a [...] como é que ela repercutiu, será que o aluno saiu minimamente com a noção do que ele pode fazer adiante, será que o aluno daqui, ele sai com a perspectiva de continuar os estudos, e se ele sai com a perspectiva de continuar os estudos que estudo é esse que ele sai, porque se ele sair daqui, com a perspectiva de ser engenheiro e fazer uma faculdade, de ir pra USP alguma coisa deu errado, porque na verdade a gente não ta fazendo muito diferente do que $\mathrm{N}$ coisas fazem por aí, então a gente não transformou, não deu ferramentas pra que ele possa de fato transformar a perspectiva de vida dele. Acho que são questões que devam talvez ser pensadas, nas outras questões, do ponto de vista metodológico, plano de curso, acho que são questões, mas eu acho que do ponto de vista de nortear o programa, eu acho que elas ficam secundarizadas, eu acho que é um pouco isso. (CORD1, 2007)

A EJA deveria de uma maneira não diria nem introdutória, nem básica, mas ela deveria de alguma forma conversar com a educação profissional, com a profissionalização das pessoas, num aspecto mais geral e de forma a ajudar essas pessoas a encontrar a forma de profissionalização delas. Acho que isso é bastante adequado porque muitas vezes os objetivos das pessoas quando elas procuram uma espécie de formação, eles são bem direcionados, então no nosso trabalho há um problema, que a gente não pode, embora a gente desejasse, aprofundar muito na área profissional, porque grande parte das pessoas que procuram, elas procuram a elevação da escolaridade e não a formação profissional. Então, são cursos distintos, com objetivos distintos, e que eu acho que é natural as pessoas que procuram com algum objetivo, que dificilmente é um objetivo duplo [...] há sempre uma tentativa ou esforço de levar as pessoas à qualificação [...]. (CORD2, 2006) 
Há uma preocupação em como resolver os problemas da qualificação profissional, dos itinerários e cursos.

E, às vezes, no decorrer do ano aí ele não se identifica muito. Mas aí é que tá, o Programa ele não te dá o direito de você pular de um curso pro outro. Nesse aspecto, é ruim, eu acho, porque você fica com o acesso do específico o ano todo, e aí não dá pra você parar de fazer Elétrica e no meio do ano ir pra Hidráulica, que são cursos completamente diferentes. Talvez, se pensando em módulos, em itinerários, em módulos com cargas horárias, e o aluno escolhesse fazer um módulo básico e depois tentar fazer os módulos e ele poder ir pra cada um, eu acho que seria mais, mais correto, não sei, eu não consigo visualizar muito bem isso, não sei como que se daria esse processo. Não sei se, por exemplo, se a gente projetasse 100 horas pra um curso, 100 horas pra outro, essa qualificação profissional daria conta. Mas tem os cursos livres que também ele poderia estar voltando, que são cursos também em período inverso e estar podendo também se qualificar mais. $\mathrm{O}$ que ele perdeu talvez dentro do PIQ, ele pode retornar nos cursos livres... (DIR3, 2006)

[...] então eu acho que o PIQ ele tem, eu começo a falar e repensar no que eu tava falando, eu acho que o PIQ ele tem um problema na concepção da formação profissional, dos cursos e do perfil dos alunos, e tem o problema quando você, na entrada e no final, que se ter a certificação, você vai certificar o que mesmo? Tendo em vista que você não sabe direito como é que vai propor o curso, e daí o Itinerário ele fica com um problema que contribui, ele é dos problemas que você leva em conta, deveria levar em conta no desenho do curso, e lá na certificação, né? Na verdade, ele é um recurso muito interessante, mas assim se você não tiver esses aspectos resolvidos ele não ajuda muito, porque o aluno vai dizer assim "sim, eu vou optar entre esse módulo ou aquele" e na verdade você quando sugeriu ao aluno fazer um modulo A ou modulo B você já deveria, lá na certificação saber por que você ta oferecendo isso. Então, deveria, na verdade, ter uma discussão apropriada, e eu falo com todos os atores que estão, os agentes que são atores importantes que oferecem os cursos, e a gente não pode fugir dessa responsabilidade, seja ONG ou a Prefeitura deveriam na verdade ter as possibilidades as várias possibilidades possíveis, de onde é que o aluno pode chegar - eu to falando isso genérico, na questão pedagógica eu não vou entrar por que eu não domino - mas aí você poderia mostrar pro aluno as várias possibilidades. Ou em sintonia com o mercado, ou em sintonia com o que já foi feito. Olha, você pode seguir comandos, casa inteligente, por aqui, por aqui e por aqui, mas aí o aluno diz "ah, mas por que eu vou fazer esse Itinerário?" que nem uma universidade, você pode fazer assim por que existe proteção do mercado, você pode fazer assim por que você vai ser mais, um profissional mais pra linha de comandos industrial, que pra residencial. Então essas possibilidades a gente tem muita dificuldade em oferecer porque a gente tem problema de modulalizar isso e tem problema dessa definição de ciclo ou de série...

Eu acho que é isso, a falta de fórum pra discutir a formação profissional, ela acaba... Como a gente está na verdade implementando, a teoria na verdade ela vem a reboque da prática, pelo menos nessa realidade que a gente está, primeiro que a teoria ela está muito descompassada, a teoria hoje que a gente vê nos referenciais ela está muito embasado em estudos de caso. No nosso caso a gente tem muito pouca, na formação profissional, tem muitas 
experiências, mas elas são muito descontextualizadas, então tem várias experiências interessantes, mas elas estão num contexto que às vezes você não consegue implementar. Então, o que ocorre? A gente tem um problema sério de você ter essa visibilidade, ter esse olhar do ponto de vista da teoria, contribuir com a pratica, e de você apontar algumas diretrizes, ainda que elas sejam diretrizes mesmo, no sentido da gente avançar. A formação profissional, de uma maneira mais geral, eu acho que ela carece muito, no Brasil, desse tipo de olhar. O que a gente tem é o modelo do SENAI, tem o modelo da CEFET, enfim outros modelos aí, que são muito desconectados e a gente tem um plano, Governo Federal lançando mão de uma série de experiências, que são todas desconectadas, todas descompassadas, e que não fazem esse tipo de reflexão, "bom, mas afinal o que nós estamos fazendo?" . Então, fica assim, cada um, cada programa se encerra nele mesmo, PROJOVEM, Primeiro emprego. [...] E muito menos conversa. entre aspas se a gente fizer uma educação politécnica, você teria um componente de mercado, ainda que ela seja muito pequena, perto da concepção social, uma concepção mais [...] de formação profissional ainda assim você teria que, "mas eu to formando que tipo de profissional?". Nem é isso, se você for fazer uma avaliação de efetividade, ainda que formação profissional não gere emprego, você teria que ver o seguinte, olha qual a contribuição do programa essencialmente na formação profissional desse pessoal. E, por exemplo, dos que foram contratados, não que você vá contribuir [...] o que eles estão desempenhando que foi interessante. Esse tipo de retorno pelo menos aqui a gente nunca teve. E aí tem aquela discussão, afinal, o que nós estamos discutindo? A formação profissional. Esse aluno que sai, qual é a nossa responsabilidade e qual é, do ponto de vista de atuação dele, o que nós estamos contribuindo na vida dele [...]. Então eu acho que em termos de efetividade, a gente precisava analisar melhor os programas de qualificação profissional, geral, não estou falando o nosso, eu acho que até a gente até faz um esforço grande, por que assim, com exceção do SENAI que faz uma coisa muito voltada pro mercado, muito fechada assim, que talvez eles tenham efetividade por conta disso, mas não discutem mais nada, a gente, eu fico pensando se a gente tem efetividade, teria que discutir, ter indicadores pra isso. Eu acho que a gente não tem claro, quais os indicadores que são importantes pro PIQ. (CORD3, 2006)

Hoje é um supletivão na realidade, é assim que eu estou vendo. Infelizmente estou sentindo assim, que o específico só está sendo um chamariz, um atrativo, o que é uma pena, uma grande perda, não que não tenha que ter elevação de escolaridade para aquelas pessoas que só querem isso. Para isso nós temos o estado, o Programa original mesmo, que era... políticas pedagógicas....qualificação profissional...e auto estima, autonomia, era trabalhado tudo isso, mas nem lembro mais o programa para você ter uma idéia de como já se perdeu pelo caminho. É uma pena, uma grande pena, porque os Centros Públicos com esse Programa era referência na nossa cidade. (Marina, 2007)

[...] como eu disse, então o Departamento centralizou os cursos nos Centros, se esta área aqui é estética então é falado para o aluno você vai fazer estética, então é estética. Não tem como. Se vai no Armando Mazzo é construção civil, não vai ter estética lá. Então ele tem que optar, ou ele vai fazer elevação de escolaridade, eu tenho que fazer, eu tenho que fazer, porque eu preciso, então ele se submete às vezes ao curso, porque aqui não tem como ser só, é casado, por isso já diz PIQ, programa de qualificação integrado, 
então ele, se ele escolher tem que fazer alguma profissão que está dentro do que é fornecido. (Marina, 2007)

Há uma grande preocupação com a direção que o programa possa tomar:

O PIQ, para mim ele já está sendo um programa supletivo e tudo leva a crer que vamos estar junto com o PROJOVEM, ou o PROJOVEM vai fazer parte do PIQ, ou PIQ vai fazer parte do PROJOVEM, porque o que está em jogo é verba. [...] acho que o PROJOVEM vai tomar conta, dizem que o PROJOVEM tem alguma coisa lá nos alicerces dele que é do PIQ, mas não sei bem isso, não li muito sobre PROJOVEM, mas acho que ele vai tomar conta mesmo dos Centros Públicos [...] e como que vai ser a gestão disso, porque, hoje, lá na escola tem PROJOVEM e você acaba tendo dois programas dentro do mesmo Centro totalmente diferentes, com equipes diferentes, com públicos diferentes e que acaba interferindo no andamento de todo o Programa, de toda a escola. (AP3, 2007)

Não sei como explicar, como foi reformulado, as mudanças que foram feitas e isso reflete sim para o aluno. Ele começa a perceber, ele fala puxa, essa escola como mudou, a gente chega e não sabe para onde vai, então acho que está tendo falta mesmo de união do grupo junto discutir. Não é que os professores não queiram, os professores continuam com o mesmo compromisso, mas como o Programa eles mudam, começa a complicar e também hoje, então o PROJOVEM veio para a nossa escola, acho importantíssimo, porque tem que ter oportunidade de estudar, só que a gente tem que ter estrutura, não vamos despejar essas pessoas, vamos despejar na escola só? E aí? Cadê a estrutura? Precisa de pessoas especializadas, são menores que já vem com problema de outras escolas, são alunos expulsos de escolas do estado, que as outras pessoas não querem mais, nem a própria família quer, os excluídos dos excluídos, só que para colocar dentro da escola, é importantíssimo isso, só que você tem que ter estrutura, pessoas capacitadas, tem que ter psicólogos, orientadores, segurança, porque infelizmente... eles estão muito rebeldes, eu penso assim. (Marina, 2007)

Porque na educação de jovens e adultos, se você for tratar como um supletivão, um supletivo que eu só venho aqui pra ter o núcleo comum, eu acabo descaracterizando, e a questão mesmo da organização popular, eu acho que a gente consegue trabalhar muito as questões de solidariedade, de envolvimento dessas pessoas no seu dia a dia, no resolver problemas do grupo todo, não olhar só pro seu umbigo, então eu acho que isso o Programa, a duras penas, a gente consegue ainda ter isso muito forte neste Centro, não sei se é pelo perfil, de ter mais mulheres, que tem essa coisa mais de coletivo, com mais facilidade, e eu vejo um retorno ainda dentro da nossa concepção que iniciou no projeto, aqui dentro a gente ainda consegue manter. (DIR1, 2006)

Eu vejo assim que falta muito debate, eu vejo que os Centros se enriqueceriam mais se debatesse com os outros Centros, porque eu acredito que a dificuldade de um Centro não é diferente do Centro A e do Centro B, as dificuldades devem ser as mesmas [...] pegar os professores, os alunos, porque nada melhor que os alunos que já passaram para eles abordarem ensaios, já foi tentado isso, já pensei por isso, e daí tentar inovar [...] Não tem o Orçamento Participativo, poderia ter o Centro Participativo, o que 
acontece aí no João Amazonas, o que acontece aí no Armando Mazzo, pegar assim os alunos, um pouco de cada um deles e jogar como se fosse o Orçamento Participativo, cada um falaria uma coisa e tenho certeza que os gestores pensariam sobre isso. Não só fazer como na avaliação final, auto avaliação, vamos pensar isso para o ano que vem [...] não, é pegar isso já, fazer crescer a equipe. (Roberto, 2006)

Todas as colocações expressam a preocupação e o compromisso de seus agentes em manter o Programa de forma que ocorra, efetivamente, o atendimento às demandas populacionais, tanto as de escolaridade quanto as de formação profissional. Cada sujeito apresenta um conjunto de conceitos e entendimentos do que seja o PIQ e, mesmo com diferenças de domínio conceitual ou de alcance político do Programa, que podem ser equalizadas por processos de formação, discussão e participação, convergem na avaliação de que existe, potencialmente, a possibilidade de que ele venha a ser um instrumento importante na construção de novos patamares de acesso à educação, propiciando maior compreens e participação nas questões do mundo do trabalho.

\subsection{O QUE OS ALUNOS TÊM A DIZER}

A aplicação do questionário nos alunos visou obter informações que qualificassem o perfil do público que participa do Programa no tocante às suas trajetórias de trabalho, suas expectativas, perspectivas em relação ao Programa Integrado de Qualificação, e sobre a forma que tem interferido em suas vidas. Procurou-se, também, em algumas das questões, suscitar, nos alunos, o interesse por temas relacionados ao campo da educação e trabalho, e, dessa maneira, viessem a indicar a sua visão da escola, a importância que lhe atribuíam enquanto instituição responsável pela transmissão de saberes e qualificação.

Foram pesquisadas seis salas, sendo duas de cada Centro Público. Todos os alunos responderam ao questionário, perfazendo um total de 79 alunos, sendo 38 homens e 41 mulheres. As salas pesquisadas foram, por Centro Público, uma de cada nível (PIQ II e PIQ III) e do período noturno, onde se concentra a maior procura da população e apresenta uma maior diversidade de segmentos de público, uma vez que nos períodos da manhã e tarde há uma maior concentração de mulheres e adolescentes.

Os Centros Públicos escolhidos apresentam particularidades no que se refere à sua área de atuação. A escolha dos Centros se deu em função de dois critérios principais: maior tempo de atividade e área de atuação consolidada. Os Centros Públicos Júlio de Grammont, 
Valdemar Mattei e Armando Mazzo iniciaram suas atividades, em 1998, e tiveram sua área de atuação definida desde 2002. Os Centros Públicos Valdemar Mattei e Armando Mazzo mudaram de prédio e de denominação, mas continuaram em suas áreas de atuação, no mesmo bairro onde antes estavam instalados.

No Centro Público de Formação Profisssional Armando Mazzo, dos 23 alunos pesquisados, apenas duas são mulheres. Neste Centro, que trabalha com a área de construção civil e que ofertou qualificação profissional somente no ensino médio, assim como os outros, durante o ano de 2006, nota-se que nesta modalidade a turma é formada na sua totalidade por homens, sendo que as duas mulheres pesquisadas pertencem ao ensino fundamental. Este Centro, em abril de 2006, atendia a 356 alunos no seu conjunto. Apresenta, também, uma particularidade referente ao atendimento. Nos anos de 2005 e 2006, não conseguiu formar turmas de PIQ no horário da tarde. Suas turmas concentraram-se nos horários da manhã e mais, acentuadamente, no noturno.

No Centro Público de Formação Profissional Júlio de Grammont, oito dos alunos são homens e 30, mulheres. Neste Centro, que trabalha com estética, a turma de ensino médio é formada, na sua totalidade, por mulheres. Com base também em abril de 2006, este Centro atendia 512 alunos.

As particularidades relacionadas a estes dois Centros serão tratadas adiante, na análise dos resultados do questionário.

Já no Centro Público de Formação Profissional de Tecnologia da Informação em Software Livre Valdemar Mattei, há a mesma proporção entre homens e mulheres: 9 homens e 9 mulheres e esta proporção se mantém também no ensino médio. Este Centro atendia em 2006, tomando-se, também, como base o mês de abril, 611 alunos no total.

Com relação à faixa etária dos alunos pesquisados, no que diz respeito aos jovens entre 18 e 26 anos de idade, o público alvo do Programa, constituem 15\% dos alunos. A maior concentração ocorre na faixa etária dos 39 aos 45 anos, que corresponde a 21,5\%, seguida pelos alunos que possuem entre 46 e 52 anos, 20,2\%, e, por fim, pelos que têm entre 25 e 31 anos, 18,9\%. Essa é uma característica do Programa, que se mantém desde o seu início, em 2003. Os jovens, público alvo escolhido com o propósito de promover sua retenção fora do mercado de trabalho através de bolsa auxílio e trabalho social, expresso nos objetivos iniciais do Programa, não correspondem à maioria da demanda. Grande parte dos que procuram o Programa, geralmente já possuem alguma trajetória de trabalho e, segundo as diretoras dos Centros, como já foi observado, aproximadamente metade dos alunos interessam-se apenas pela elevação de escolaridade. 
Com relação às informações levantadas pelo questionário, uma, em particular, que se mostrou muito interessante e torna possível estabelecer algumas relações com outras questões da pesquisa, refere-se à trajetória dos alunos. É possível observar o que entendem como trabalho (que lhe propicia satisfação ou não), o que consideram ser uma profissão, e como se dá o processo de sua construção. Para $65,8 \%$ dos entrevistados, a vida na atividade produtiva se iniciou antes dos 15 anos de idade, sendo que destes, 34,1\% a iniciaram antes dos 13 anos. Dos alunos pesquisados, apenas duas mulheres nunca trabalharam. Com relação ao primeiro trabalho, 55,6\% o iniciaram em Santo André; 15,1\% na região da Grande São Paulo, incluindo o $\mathrm{ABC} ; 2,5 \%$, no interior do estado de São Paulo; 12,6\%, na região Nordeste; 5\%, na região Sul; e 3,7\%, em algum estado da região Sudeste.

Em se tratando da primeira atividade desenvolvida entre os homens que iniciaram sua vida produtiva antes dos 15 anos, estes apontaram, basicamente, as profissões de ajudante e auxiliar de diversos ramos (07 alunos), de vendedor (04 alunos), balconista (03 alunos), office-boy (03 alunos), e lavrador (05 alunos), sendo que, esta última, concentra-se na faixa etária que vai dos 07 aos 10 anos de idade.

Entre as mulheres, para a mesma faixa etária, as profissões apontadas foram as de ajudantes de diversos ramos (05 alunas), empregada doméstica (04 alunas), babá (04 alunas), balconista e atendente (04 alunas), costureira (02 alunas), lavradora (02 alunas), guarda-mirim (02 alunas) e panfleteira (01 aluna). O interessante a observar nesse campo, é que o número de atividades apontadas pelos homens (que para efeito de melhor visualização foram aqui condensadas), foi maior do que o apontado pelas mulheres. Os homens indicaram, para a faixa etária até 14 anos, dezoito atividades, enquanto que as mulheres indicaram dez. A diversidade de ramos apontada pelos homens é maior, já que, para as mulheres, os trabalhos ligados às atividades domésticas e, por isso mais restritos, aparecem em maior número. Com relação às mulheres, também é possível verificar que uma delas começou a trabalhar antes dos 07 anos de idade, na feira. Com relação às horas de trabalho da primeira atividade, dos pesquisados, $25,3 \%$ trabalhavam de quatro a seis horas; $45,5 \%$ trabalhavam de sete a nove horas por dia; e $18,9 \%$ trabalhavam dez ou mais horas por dia. Este último grupo desempenhava basicamente as atividades de ajudante de produção (uma aluna), ajudante geral (dois alunos), costureira (uma aluna), lavoura (três alunas e um aluno), office-boy (um aluno), empregada doméstica (uma aluna) e vigilante em sistema de revezamento (um aluno).

Uma das questões colocadas aos alunos estava relacionada a conhecimentos pessoais e profissionais adquiridos com o trabalho. Entre os homens, os itens mais citados foram o domínio técnico da atividade (citado por treze alunos), atender ao público, honestidade e ser 
respeitado no trabalho. Os restantes, com apenas uma indicação para cada um, apresentam, na sua maioria, preocupação com atitudes e valores: compromisso com o trabalho, responsabilidade, saber ouvir, caráter, humildade, entendimento, sabedoria. Outro bloco trata das questões interpessoais: fazer amizades, saber relacionar-se com as pessoas, conviver com a sociedade, entender orientações, lidar com pessoas de todos os tipos, conviver em grupo, auxiliar as pessoas com o seu conhecimento. Um grupo menor detalha os conhecimentos adquiridos: informática, fazer novas coisas, interpretar desenhos, conhecer medidas.

As mulheres colocam, como principais conhecimentos adquiridos, a experiência com as pessoas, conviver e respeitar as pessoas, atendimento ao público, domínio técnico da função, fazer amizades, perder a timidez e melhorar a comunicação. Há uma série de outros itens citados apenas uma vez, que trata das relações interpessoais, atitudes e valores e mudanças pessoais. São citados: separar a amizade do pessoal, diferenciar o que é certo e errado, bom comportamento no trabalho, compromisso com o trabalho, consciência da importância de seu trabalho para os outros, trabalhar em grupo, adquirir consciência de vida, tolerância, persistência, gostar de criança, cuidar bem dos filhos, independência, pagar as próprias contas, cumprir horários, autocontrole, auxiliar as pessoas com seu conhecimento, limites, criatividade, liderança, honestidade, confiança, conhecer costumes e lugares diferentes e necessidade de estudar. De maneira geral, os alunos encontraram muita dificuldade em responder a esta questão e, tanto homens quanto mulheres, atribuem a esse aprendizado um forte conteúdo moral e de formação de caráter.

Não menos importante, as questões relacionadas às mudanças pessoais e interpessoais são muito presentes. Alguns depoimentos são interessantes para auxiliar a entender o universo dos alunos. Samanta, 31 anos, CPFP Júlio de Grammont, PIQ III, ao responder quais foram os conhecimentos adquiridos com o trabalho colocou: "Liderança e idéias criativas. Antes de trabalhar não era assim, todos falavam menos eu”. Josiane, 20 anos, mesmo Centro e mesma turma: "Aprendi a engolir sapo, a cumprir horários, ter responsabilidade, pagar minhas próprias contas e a andar sozinha”. Vilmar, 19 anos, mesmo Centro, PIQ II: “Quando eu era novato eu aprendi a não ser mandado pelos funcionários que gostam de abusar". Eduardo, 39 anos, PIQ II: “Concepção de vida: lidando com o público aprendi a conviver com pessoas e com isto moldar uma consciência de vida”. Pedro, 46 anos, CPFP Armando Mazzo, PIQ III: "Profissional interpretação de desenho e conhecimento de medidas. Pessoal é quando consigo entender as coisas”. Rosana, 29 anos, Centro Júlio de Grammont, PIQ III: “Aprendi que pessoas têm limites e que devemos respeitar todos". 
Patrícia, 30 anos, PIQ II: “O de respeitar o próximo, trabalhar em grupo, e se comunicar melhor, pois era extremamente tímida".

Apesar de a amostra da pesquisa ser restrita, é possível observar que os conhecimentos adquiridos no exercício do trabalho influenciam na constituição da subjetividade de quem o realiza, o que se expressa claramente nos registros dos alunos. Apesar de atribuírem ao trabalho uma forte característica negativa, de não se sentirem realizados no exercício de suas atividades, é ele que possibilita mudanças, principalmente as pessoais e inter pessoais, além de ser um forte elemento na constituição do caráter. Nesse sentido, a fala dos alunos confirma observações realizadas por Frigotto, Ciavatta e Ramos (2005, p.21):

Na relação dos seres humanos para produzirem os meios de vida pelo trabalho, não significa apenas que, ao transformar a natureza, transformamos a nós mesmos, mas também que a atividade prática é o ponto de partida do conhecimento, da cultura e da conscientização. (2005, p.21)

Os alunos trazem em suas colocações uma multiplicidade de elementos contraditórios acerca do trabalho. O emprego é visto como a possibilidade de ter a sobrevivência garantida; o trabalho, uma atividade que via de regra é cansativa e não possibilita crescimento; a profissão, o espaço onde a realização no trabalho pode se dar, ao mesmo tempo em que é através do trabalho que o ser humano se constitui enquanto uma pessoa digna e respeitada. Interessante notar que, apesar de o Programa ter, em seu terceiro eixo relativo à proposta pedagógica, uma perspectiva político-ideológica, a dimensão ontológica do trabalho consiste, ainda, em uma exigência a ser contemplada na proposta pedagógica.

No que se refere ao percurso de trabalho dos alunos e à satisfação pessoal que as atividades lhes trouxeram, os motivos apontados pelos homens referem-se, em primeiro lugar, à afinidade com a atividade; em segundo, à renda, seguida da satisfação em trabalhar com o público, da descoberta de novas habilidades e experiências, do domínio da atividade, do sentir-se útil, do orgulho do trabalho realizado e seu reconhecimento. Com menos indicações, aparecem, também: aprender a operar uma máquina, fazer algo e ver o resultado, aprender uma profissão e fazer novos amigos. Um dos alunos, Ildeu, de 53 anos, do CPFP Valdemar Mattei, PIQ II, fez questão de registrar todo o seu percurso profissional: 
até os 18 anos, depois resolvi partir para outras atividades. Em 1970, vim para SP e comecei a trabalhar em metalúrgica. Trabalhei como ajustador, plainador, mesa limadora, frezador e, nos últimos 28 anos, como mandrilhador.

Alguns outros depoimentos são interessantes no que toca à satisfação conseguida através do trabalho. No CPFP Armando Mazzo, da turma de PIQ III, como Milton de 49 anos, alguns alunos se colocam ao tratar das atividades desenvolvidas e que lhes deram satisfação:

\begin{abstract}
Mecânico de manutenção, serralheiro, encarregado de montagem, encarregado de manutenção, supervisor de montagem e tubulação industrial, técnico de montagem. Todos os trabalhos realizados por mim foram satisfatórios, pois à medida em que fui evoluindo profissionalmente, fui desenvolvendo habilidades que desconhecia frente a cada dificuldade que eu enfrentava e vencia.
\end{abstract}

Rogério, de 39 anos: "Com pintura e também como impressor gráfico. Porque é um serviço em que a gente faz e vê o resultado". Pedro, 41 anos: "Organização de arquivos administrativos em empresas de grande porte, multinacionais. Trabalho como arquivista desde o ano de 1985, e organizei alguns arquivos de empresas multinacionais”. Na mesma direção coloca Roberto, de 37 anos:

Office-boy, vendedor, comprador, editor de vídeo. O que mais me deu satisfação foi editor de vídeo. Porque eu trabalho em uma produtora que insere os vídeos em emissoras de TV, e quando você vê que seu trabalho gera resultados positivos para o cliente, eu me sinto vencedor.

Ao se referir ao trabalho que trouxe satisfação, dois alunos colocaram o orgulho em relação à sua profissão e, ao mesmo tempo, a frustração com as alterações ocorridas, decorrentes das políticas de trabalho. José, de 49 anos, CPFP Valdemar Mattei, PIQ II, coloca:

Ajudante de elétrica, que recebi classificação de eletricista porque tinha prática; ao passar dos anos perdi o emprego e aí piorou a situação. Porque teve mudanças de governo e aí piorou a minha vida financeira

José mostra que, mesmo sem escolaridade ou curso de qualificação, recebeu classificação de eletricista em função dos conhecimentos adquiridos na prática e que foram reconhecidos. Para Paulo, 33 anos, CPFP Júlio de Grammont, PIQ II: 
Bom o trabalho com o qual mais me desempenhei foi como promotor de vendas. È um trabalho que tenho 17 anos de carteira. Mas, com minha idade, acham que já estou velho para trabalhar. E fora isso tenho 4 diplomas, mas faz 1 ano que estou parado com toda essa experiência. Porque quando vai chegando a idade, parece que você não precisa mais sobreviver.

Como se observa, ao contrário de José, Paulo tem uma profissão reconhecida por quatro certificados de qualificação, não tem a escolaridade completa, o que não o impediu que ficasse desempregado.

Quanto às mulheres, a afinidade com a atividade também aparece, em primeiro lugar, e, diferentemente dos homens, antes da obtenção da renda, na satisfação de trabalhar com o público e na descoberta de novas habilidades e experiências, seguidas pelo orgulho do trabalho realizado, pelo reconhecimento, no fazer novos amigos e conhecer pessoas, pela transformação pessoal, pelo registro na carteira, e por exercer um trabalho menos pesado. Com menos indicações, estão: trabalhar com pessoas educadas, conhecer todas as tarefas da atividade, exercer a muito tempo a mesma atividade, trabalho digno, permanência do que foi aprendido no trabalho.

Com relação às atividades apontadas que trouxeram satisfação pessoal, é possível observar a diferença entre homens e mulheres e, também, algumas diferenças entre os Centros. A diferença entre homens e mulheres se dá no tipo de trabalho, onde é possível observar o leque de atividades que homens e mulheres exerceram e exercem. Os homens dos CPFP's Armando Mazzo e Valdemar Mattei exercem um maior número de atividades industriais, como mecânico de manutenção, encarregado de montagem, supervisor de montagem e tubulação industrial, eletricista, ajustador mecânico, torneiro mecânico, almoxarife, ferramenteiro, frezador de peças, plainador, entre outras. Referem-se, também, a atividades ligadas ao comércio e serviços, mas, é interessante notar no que, percurso profissional dos alunos desses dois Centros, há uma presença significativa de ocupações qualificadas, ligadas aos postos de trabalho que a indústria oferece ou ofereceu. No CPFP Júlio de Grammont, essa característica não está presente (três alunos apenas indicaram postos de trabalho relacionados à indústria), porque havendo quase o mesmo número de homens pesquisados no CPFP Valdemar Mattei, não há, neste Centro, homens cursando o ensino médio. Por essa razão, pode-se supor que a baixa escolaridade apresentada (estão cursando o ensino fundamental) explique o fato de, em sua trajetória, exercerem funções mais ligadas ao comércio e serviços, e de ajudante ou auxiliar ligado à indústria, e de que mostrem satisfação no desempenho dessas atividades, em contraposição aos outros, que colocam essas ocupações como insatisfatórias. 
Com relação às mulheres, a diferença é visível. Nos três Centros Públicos em questão, de todas as mulheres pesquisadas, apenas oito tiveram postos de trabalho na indústria e todas na função de operadora de máquina, auxiliar de produção ou atendente. $\mathrm{O}$ restante das atividades, estão relacionadas ao comércio e aos serviços, em funções que não exigem qualificação ou pressupõem uma baixa qualificação (empregada doméstica, vendedora, copeira, cozinheira, balconista, costureira, bordadeira, artesã, revendedora de cosméticos, recepcionista, feirante, balconista, entre outras). Rita, de 30 anos, CPFP Júlio de Grammont, PIQ II, ao se referir aos trabalhos que lhe deram satisfação, observa: "Foram 2. No Vale do Rio Doce trabalhava de atendente e vendedora. Porque foi onde eu comecei a ter um trabalho digno e registrado". Lenira, 44 anos, do mesmo Centro e mesma turma: "Sempre trabalhei como doméstica fora e em casa. Porque desde cedo comecei nesse ramo, trabalhava com minha mãe e, depois, passei a trabalhar sozinha”. Rosana, 29 anos, da turma de PIQ III:

Trabalhei com vendas e reportagens fotográficas assistente de dois arquitetos, vendedora de perfumaria importada, revelação de filmes, massagista e mãe que é um grande trabalho, adoro o que faço hoje graças a meu curso, sou esteticista.

O curso de estética abriu caminho para minha independência tanto financeira quanto espiritual, é importante se sentir cidadão e poder ter o que é seu por sonho e conquistar o que deseja.

Sebastiana, 34 anos, também PIQ III:

Onde eu morava eu gostava muito do meu trabalho, aqui em São Paulo trabalhei no sacolão que também foi bom, depois fui montar peças de telefones e por fim trabalhei de ajudante de cabeleireiro e por último em casa de família.

Todos eles tive uma grande satisfação pessoal porque gostava do que eu fazia. Estou há 10 anos trabalhando como doméstica e queria muito poder exercer outra profissão.

Darci, 42 anos, do PIQ II:

Foi trabalhar de operadora de máquina quando me deram oportunidade de aprender lidar com a máquina de enchimento de pomada. Ali eu estava aprendendo ter um bom conhecimento, foi uma satisfação.

Ao entrar na questão que trata da insatisfação com o trabalho, pode-se observar que os homens, de modo geral, colocam como insatisfatórias as atividades que não requerem qualificação, na maioria ligadas aos serviços e que se caracterizam por "bicos" (vendedor, 
balconista, pipoqueiro, sorveteiro, empacotador, ajudantes de diversos ramos, lavador de carros, vigilante, office-boy, catador de lixo reciclável, lavrador). Para os homens, os motivos que levaram a insatisfação em tais atividades foram: a ausência de perspectiva de melhora, por ser cansativo e desgastante, falta de afinidade com a função, trabalho insalubre ou perigoso, sem direitos ou benefícios, pouco remunerados, não valorizados, humilhantes. Outras situações apareceram com menor evidência: o trabalho não permitiu continuar os estudos, trabalho muito solitário, muita exploração, sem qualificação, não exigia nenhum esforço mental, não era uma profissão, era instável, oscilante.

Alguns depoimentos contribuem para ilustrar o que foi colocado. Antônio, de 53 anos, do CPFP Valdemar Mattei, PIQ III, ao se referir aos trabalhos que desempenhou e que não trouxeram satisfação, afirma: “Ajudante de pedreiro. Sofre muito”. Lucas, de 43 anos, do mesmo Centro e da mesma turma: "Catar lixo reciclável para vender foi humilhante. Ninguém conversava comigo e tinha poucos amigos". Do CPFP Armando Mazzo, algumas colocações também foram bastante interessantes. Celso, 29 anos, PIQ III, sobre a mesma questão: "Foram os de pipoqueiro, sorveteiro e empacotador. Porque é um serviço leve e fácil de executar", referindo-se ao fato de essas atividades não lhe exigirem qualificação ou conhecimentos mais elaborados. Ele colocou em seu questionário que nunca teve um trabalho que lhe deu satisfação. Pedro, 46 anos, do mesmo Centro e mesma turma: "Servente de pedreiro, trabalhar com herbicida, cortar cana e fazer faxina. É cansativo e perigoso". Anderson, 27 anos: "Lava rápido, ajudante de pedreiro. É muito pesado e nada reconhecido e um pouco humilhante". Jorge, 47 anos: "É trabalhar na área de construção civil como servente. É como se fosse para lugar nenhum, carregando massa de concreto, tijolos, etc".

No caso das mulheres, elas também colocam como insatisfatórias as ocupações de ajudante e auxiliar de ramos diferentes; as ocupações que não requerem qualificação, basicamente as ligadas aos serviços domésticos, algumas ao comércio, mas que não necessariamente se caracterizam como "bicos" (empregada doméstica, babá, cuidados a idosos, garçonete, lavradora, diarista). Como "bico" A atividade mais citada como "bico" é a de panfleteira, desempenhada pelas mulheres mais jovens.

Os motivos da insatisfação, diferente dos homens, não foi , em primeiro lugar, a ausência de perspectiva de melhora, citada apenas por uma aluna. O principal motivo da insatisfação consistiu no fato de o trabalho ser cansativo e desgastante, o segundo motivo de insatisfação, para os homens. Em seguida, vem a falta de afinidade com a atividade, o fato de o trabalho ser humilhante, de muita exigência e pouca remuneração, não valorizado e sem reconhecimento, insalubre ou perigoso, não permitir a continuidade dos estudos, muita 
exploração, ter começado a trabalhar muito cedo, ausência de direitos ou benefícios. Os menos citados foram: a ausência de perspectiva de melhora, a diferença de salário entre homens e mulheres para a mesma atividade (garçonete).

Alguns elementos interessantes podem ser observados, pois certas ocupações, colocadas como satisfatórias, por algumas delas, são vistas como insatisfatórias, por outras (empregada doméstica, ajudante de produção, babá). No caso de auxiliar de limpeza, função por si só é colocada como insatisfatória, dependendo da situação ganha uma outra conformação, pois agrega elementos que a tornam satisfatória. Quando perguntadas sobre os trabalhos que desempenharam e que trouxeram satisfação, Salete, de 35 anos do CPFP Júlio de Grammont, PIQ II, escreveu:

Foi em uma escola esse foi o meu primeiro emprego com carteira assinada.
Lá eu trabalhava na limpeza e ajudava como podia a cuidar das crianças.
$2^{\circ}$ trabalho é em outra escola que eu trabalho até hoje.
Porque nesses dois empregos foi onde tive registro na carteira algo que pra
mim é muito importante. E é nessa área que eu lido com crianças essas que
eu gosto muito.

Maria Aparecida, de 56 anos, também do CPFP Júlio de Grammont, PIQ II, colocou o seguinte com relação ao seu trabalho como auxiliar de limpeza: "Auxiliar de limpeza, fui trabalhar no elevador. E gostei muito. Porque aprendi a mexer no elevador”. Ela também menciona este trabalho como insatisfatório, pois "tinha pouco tempo para limpar os elevadores". Outros depoimentos também contribuem para compor este quadro. No mesmo Centro, Rita, PIQ II, já citada anteriormente, ao se referir aos trabalhos menos satisfatórios, comenta: "Cuidar de um doente em cima de uma cama, pois me sentia muito triste. Porque limpava coco, xixi, e meu trabalho não era reconhecido". Anteriormente, ela havia se referido à sua satisfação em ter trabalhado no Vale do Rio Doce, como atendente. Patrícia, 30 anos, PIQ II: "Auxiliar de empacotamento em uma firma. Porque tinha que trabalhar no ritmo da máquina, embalando pipocas de microondas, algo que não me acrescentava nada”. Maria do Carmo, 38 anos, também PIQ II:

Trabalhei sempre como empregada doméstica, pois era mãe solteira e tinha que me virar para criar o meu filho, sendo assim, nenhum trabalho me satisfez pois eu trabalhava por obrigação.

Nenhuma me deu satisfação pois embora trabalhando muito, nunca fui registrada.

Fui muito humilhada e sempre que saía pra procurar outra coisa, nunca me pagaram nada como indenização. 
Karina, 16 anos, a mais jovem das pesquisadas, CPFP Valdemar Mattei, PIQ II, coloca sobre sua experiência insatisfatória com o trabalho: "Eu não gostava de trabalhar entregando papel na rua. É muito humilhante".

O que é comum, para a maior parte dos homens e mulheres em suas trajetórias profissionais é o fato de que quando puderam exercer uma ocupação que em seu entendimento era mais qualificada, no sentido de ter lugar definido no processo de produção e reconhecimento social, essa atividade ganha o estatuto de trabalho satisfatório. Essa constatação remete ao conceito de qualificação entendido como relação social. A esse respeito, ao se referir ao trabalho como elemento essencial da construção identitária e de pertencimento a um coletivo, Costa (2006) observa que diante de um quadro de ausência de emprego e da existência de trabalho precário ou contingencial, da perspectiva da perda de um trabalho e das condições socialmente valorizadas (direitos trabalhistas assegurados, reconhecimento social, remuneração permanente) a subjetividade dos sujeitos é afetada, o princípio da identidade e o sentimento de pertencimento a um coletivo, perdidos. Portanto, as ocupações mencionadas, principalmente aquelas ligadas à indústria, ou mesmo a outros setores que detenham um reconhecimento social (trabalhar em uma escola, por exemplo), em postos pouco qualificados e com intensa exploração do trabalho, representam, de qualquer maneira, uma situação socialmente melhor do que a perspectiva da ausência de emprego ou adaptação a atividades intermitentes. No limite, é melhor estar dentro de uma hierarquia de trabalho do que não pertencer a nenhum. Em entrevista, CORD1 refere-se a essa situação, considerando que "para o horizonte profissional dos alunos, ser recepcionista é o máximo que se almeja".

Outro fator a ser considerado é a caracterização dessas pessoas como classe trabalhadora. Vendedores de sua força de trabalho, passaram e passam por situações em que o trabalho, como colocam Frigotto, Ciavatta e Ramos, assume, no capitalismo, a forma "[...] das relações de exploração do trabalhador, de alienação ou de expropriação de seus meios de vida, de seu salário, da terra onde vive, e de suas possibilidades de conhecimento e de controle do processo do próprio trabalho" (2005, p.24). A ausência da compreensão crítica do trabalho, de sua dimensão ontológica, compromete o entendimento do trabalho alienado, vivido cotidianamente. Desta maneira, a perspectiva da sobrevivência através do trabalho aparece como única dimensão possível em um contexto de desemprego, de alcançar, através do trabalho, da melhor remuneração e do acesso aos direitos trabalhistas, a realização subjetiva e a possibilidade de mobilidade social. 
Há diferenciações no interior da classe trabalhadora. No caso aqui presente, neste recorte de população, existem três aspectos diferentes que precisam ser entendidos e que configuram a situação de vulnerabilidade social a que essas pessoas estão submetidas. Um deles diz respeito aos jovens, situados na faixa etária dos 16 aos 24 anos de idade. Dos doze jovens pesquisados, apenas um relatou alguma experiência em indústria, como auxiliar de produção. Com exceção de duas mulheres que nunca trabalharam remuneradamente, todos os outros têm alguma trajetória de trabalho, geralmente em atividades pouco ou não qualificadas no comércio e serviços. Todos apresentam expectativas quanto ao mercado de trabalho e têm planos para o futuro. Há uma bibliografia razoável que trata da questão da juventude, ou juventudes, como alguns autores colocam, e seria interessante fazer essa discussão, uma vez que o Programa, em sua proposta inicial, estaria dirigido a esta população. No entanto, para fins de conclusão desta pesquisa, esta questão não será aprofundada.

Outra questão importante é a de gênero. O objetivo aqui, neste momento, não é, também, o de aprofundar a questão, mas apontar alguns elementos que caracterizam o universo pesquisado. Nessa questão, é interessante destacar duas situações registradas pelos alunos nos questionários aplicados.

Com relação aos homens, notadamente no CPFP Armando Mazzo, mas também presente no CPFP Valdemar Mattei e no CPFP Júlio de Grammont, é possível observar os efeitos da reestruturação produtiva e da eliminação de postos de trabalho. Esses alunos estão migrando de sua área de atuação anterior e buscando novas ocupações e formas de trabalho. Saíram de uma situação de estabilidade no emprego, reconhecimento, qualificação do trabalho e remuneração razoável para uma situação em que, depois de passada a juventude, vêm-se obrigados a reconverter suas trajetórias.

No que toca às mulheres, é interessante observar as diferenças de inserção no mundo do trabalho. Enquanto que a maior parte dos homens pesquisados tiveram trajetórias na indústria, em funções ligadas à produção, com alguma qualificação, a maior parte das mulheres tiveram trajetórias ligadas aos serviços domésticos, comércio ou serviços, em funções que, na sua maior parte, não exigiam qualificação. Mesmo as que trabalharam na indústria, o fizeram em funções que não requeriam qualificação. Segundo Abramo (2005), de acordo com uma pesquisa realizada sobre as cadeias produtivas e a segmentação de gênero, essa é uma situação bastante freqüente. Nas empresas analisadas, ocorria um triplo processo de segmentação que afetava negativamente a força de trabalho feminina, no que se referia a processos de qualificação. A pesquisa mostrou que as mulheres ocupavam os níveis inferiores da cadeia produtiva, em empresas de menor conteúdo tecnológico, exercendo funções em que 
o trabalho se caracterizava por ciclos curtos e repetitivos. Em tal contexto, não se colocam como necessárias ações de qualificação. Mesmo quando escolarizadas, eram alocadas para funções que requeriam uma atividade aquém do seu nível de escolaridade. Conforme Hirata,

As ações de requalificação não têm a mesma amplitude nem o mesmo alcance, e tampouco a mesma significação para as mulheres e para os homens, e a formação pode ser o próprio espaço de construção da incompetência técnica das mulheres. (2002, p.224)

Ao tratar da questão da reprodução da divisão sexual do trabalho, aponta que

As "novas" relações sociais continuarão a reproduzir a situação em que as qualificações femininas são reconhecidas apenas como talentos naturais, da mesma maneira que outros processos sociais que distanciam as mulheres do controle da nova tecnologia. (2002, p.229)

Sobre a questão da divisão sexual do trabalho, chama a atenção para o fato de que as inovações tecnológicas afetam principalmente as mulheres não qualificadas, uma vez que os postos que requerem tarefas mais simplificadas são os primeiros a desaparecer.

É importante tratar dessas questões, uma vez que o questionário aplicado nas alunas apontou para sua existência, confirmando as tendências existentes na sociedade brasileira. Se a questão das inovações tecnológicas afeta os trabalhadores, homens e as mulheres, qualificados, suas conseqüências para os menos qualificados, em, em particular, as mulheres, são muito maiores. A maior parte das mulheres pesquisadas, público do Programa analisado, estão no limiar das atividades domésticas e cotidianas. Algumas se orgulham e sentem prazer nisso, outras, desejam novos conhecimentos e novas experiências de trabalho. Ao fazer algo que não seja o trabalho que já é exercido no seu cotidiano familiar, sentem-se capazes de aprender e sentirem-se pessoas produtivas. Nessa linha de raciocínio, parece "natural" que a apropriação de saberes técnicos e tecnológicos, da própria ciência, não faça parte do universo feminino. Anteriormente, foi citada a questão da constituição da classe trabalhadora. Essas são mulheres operárias, mas que parecem estar muito distantes do universo da produção das riquezas e do conhecimento. A divisão sexual do trabalho é um processo histórico, ligado à divisão social do trabalho, e o trabalho assalariado nasce, favorecido pelo trabalho doméstico, e estes se desenvolvem de acordo com as mudanças das relações de produção (HIRATA, 2002). Tratar da questão de gênero, portanto, significa tratar da própria constituição da classe trabalhadora. 
Uma outra questão que traz elementos para a compreensão de qual é o entendimento que os alunos apresentam acerca de suas trajetórias e perspectivas, é a dos trabalhos que se tornaram uma profissão e por quê. Neste item, é interessante notar que, com relação às ocupações colocadas pelos alunos e alunas, há uma diversidade considerável. Mesmo para o grupo dos homens, não foram apontadas apenas as ocupações ligadas ao trabalho industrial, mas, também, várias outras ligadas ao comércio e aos serviços, inclusive em funções como ajudante e auxiliar. No caso das mulheres, o mesmo acontece, mas não com tanta incidência como no caso dos homens, e algumas ocupações que antes foram apontadas como insatisfatórias, são também indicadas como trabalho que se tornou profissão. No caso feminino, entretanto, visualiza-se uma diferença: enquanto apenas dois homens indicaram que nenhum dos trabalhos lhes deu uma profissão, nove mulheres apontam que nenhum dos trabalhos se tornou uma profissão.

Com relação aos motivos que fizeram com que tais funções se tornassem uma profissão, entre os mais citados, os homens consideraram, primeiramente, a ampliação de conhecimentos e experiências, e, em seguida, a aferição de renda razoável, a afinidade e o prazer propiciados, ter o domínio completo da função, maior oportunidade de trabalho, promoção, oferecimento de cursos de qualificação pela empresa dentro da função.

As mulheres apontaram em primeiro lugar, assim como os homens, a ampliação de conhecimento e de experiências; depois, a afinidade e o prazer, o domínio completo da função, poder trabalhar autonomamente, atender o público, e o reconhecimento do trabalho. Um elemento muito importante que mostra a precariedade das atividades desenvolvidas pelas mulheres, é o fato de nenhuma delas ter se referido ao ganho de uma renda razoável como motivo para que determinada função se tornasse uma profissão. Enquanto que, para os homens, esse é o segundo fator mais indicado, no caso delas não é m sequer citado. Um outro aspecto, indicado pelos homens e pelas mulheres, citado uma única vez, foi a possibilidade de realizar a qualificação, ofertada pelo empregador.

A questão relativa à diferença entre profissão, trabalho e emprego foi tratada com o conjunto dos alunos pesquisados: para 64,5\% deles há diferença entre as três definições; para $25,3 \%$ não há diferença, e 6,3\% não responderam. Entre os que definem diferenças, nove alunos definiram profissão, mas colocam que emprego e trabalho são idênticos. Em sua maior parte, conseguiram dar alguma definição para profissão, mas apresentaram maior dificuldade para definir trabalho e emprego. 
As definições de profissão apresentadas pelos alunos foram as seguintes: em primeiro lugar, colocaram que a profissão tem relação com o estudo e é a especialização em uma área desejada; em segundo, na mesma proporção, indicaram que é algo que se pode escolher, o que está registrado na carteira, algo que se conquista pelo conhecimento e algo que se aprende a fazer; em seguida, mencionam o que se faz por prazer, o que se luta durante vários anos para ter; o que traz maior reconhecimento e salário, o que traz reconhecimento e prazer, o que se exerce durante muitos anos, o que se adquire com curso profissionalizante, qualificação. Outros itens foram citados, mas apenas uma vez, conforme consta na tabulação dos resultados: traz melhores oportunidades, capacidade, é para a vida toda, carreira.

Com relação à definição de trabalho, ocorreu um número menor de tentativas de definição e poucas tiveram mais de uma indicação. As mais indicadas foram: obrigação, o que aparece quando está desempregado, algo que não tem opção (obrigatório). As outras indicações colocadas pelos alunos trazem, na sua maioria, uma visão extremamente negativa do trabalho: esforço e cansaço, não precisa de estudo, todo mundo tem, só conhece trabalho informal, limpar a casa no fim de semana, o que se consegue fazer por algum tempo, aquilo que me ocupa, sobrevivência, o que precisa ser feito, não precisa de qualificação. Poucos vêem o trabalho como algo positivo: algo importante para a vida, vontade e esforço, algo que temos que ter para a vida, o que traz dignidade, exercer sua carreira, o que se aprende fazendo.

Com relação ao emprego, também houve dificuldades em sua definição. As mais citadas foram: registro na carteira, trabalhar e receber, fazer o que aparece, trabalhar porque precisa, oportunidade, o que garante o salário mesmo que não goste do que faz. As definições menos citadas assemelham-se ao que foi colocado em relação ao trabalho, reafirmando o seu caráter negativo: é o que querem que você faça, rotina, não precisa de estudo, obrigação, difícil de encontrar, um trabalho qualquer, a meta de quem está parado, não exige estudo. Alguns alunos apontaram o seguinte: fazer uma atividade, o que vai conhecer e aprender, segurança, o mais importante, busca pessoal. Ao tratar das trajetórias dos trabalhadores em situação mais precária, Ferreti mostra em seu trabalho que “[...] os trabalhadores cuja origem são as classes subalternas praticamente não dispõem de liberdade de escolha de suas ocupações quando pretendem ingressar na PEA ou são obrigados a fazê-lo, muitas vezes precocemente, em virtude de pressões econômicas" (1988, p.169)

A fim de estabelecer um diálogo entre o que os alunos definiram como profissão e o que pode ser utilizado como conceito para defini-la, Franzoi utiliza a seguinte referência: 
[...] a profissão de um indivíduo é resultado da articulação entre um conhecimento adquirido e o reconhecimento social da utilidade da atividade que esse indivíduo é capaz de desempenhar, decorrente do conhecimento adquirido. Esse reconhecimento social da utilidade dessa atividade se dá através da inserção do indivíduo no mercado de trabalho, correspondente ao conhecimento adquirido. Estreitamente ligado a esse reconhecimento social e ao saber nele implicado está o reconhecimento pelo sujeito que é deles portador. (2006, p.20)

Há algumas afinidades entre o conceito de profissão descrito e o que foi colocado pelos alunos. Explicitam que a questão do conhecimento está incorporada ao conceito de profissão. Este é o elemento mais presente nos registros dos alunos. O reconhecimento também aparece, embora em menor proporção. Há dois elementos freqüentes nas colocações dos alunos que merecem destaque. O primeiro, e que talvez possa ser determinado pela trajetória desses alunos, é o fato de relacionarem a idéia de profissão à de conquista, de um processo que se constrói lentamente. É a conquista do conhecimento e do fazer. A profissão então, é a preparação do trabalhador para o trabalho, que não é qualquer trabalho, uma vez que ele demanda conhecimentos que se referem tanto ao saber tácito, conquistado pela prática, quanto ao saber aprendido fora do trabalho, o estudo. Os alunos também colocam que a profissão traz o reconhecimento social, representado através de melhor remuneração. Em menor escala, tratam da questão da qualificação como condição para a profissão. Está implícita na conceituação dos alunos a idéia de que a consolidação de uma profisssão se dá em seu exercício no mercado, uma vez que a idéia do fazer realiza-se nele. Não colocam a possibilidade de uma profissão sem seu exercício. Nesse ponto, Franzoi também destaca em seu trabalho:

[...] a articulação entre formação e inserção não se dá de forma linear, uma vez que se estabelece um espaço que não é neutro, como visto, mas construído socialmente, como resultado das disputas estabelecidas entre os atores em cena. Neste sentido, para que se realize, a profissionalização necessita de uma rede que articule a formação e a inserção. (2006, p.51)

O segundo tem relação com o desejo, o que se almeja em termos de realização pessoal. Das três definições solicitadas, este foi o momento em que ficou explícita a perspectiva de realização pessoal através do trabalho. É o conhecimento e o fazer que levam a uma realização pessoal. No entanto, apontam que a profissão não é algo para todos, demonstrando clareza sobre a hierarquização dos postos de trabalho e se colocando em dado lugar nessa hierarquia. Interessante notar que na questão que trata dos trabalhos que se tornaram profissão, um dos critérios mais citados entre os homens, e pouco entre as mulheres, 
foi a obtenção de um bom salário, de uma renda razoável. Aqui, a questão do salário não aparece com tanta ênfase, no entanto, a dimensão do prazer, da realização, da conquista é bastante presente.

Na questão que trata do curso de qualificação profissional, de como ele pode auxiliar na vida do aluno, as respostas foram separadas por Centro, uma vez que cada um deles trabalha com uma área profissional e seria interessante perceber se existiam diferenças relacionadas a isso. Nos Centros Armando Mazzo e Valdemar Mattei, o item mais citado foi a possibilidade de ter um trabalho e gerar renda como autônomo. No Centro Júlio de Grammont, o mais citado foi ter uma profissão reconhecida. No CPFP Armando Mazzo, os itens seguintes mais apontados foram: melhorar o que já faz em seu trabalho, mudar de ramo, ter uma profissão reconhecida. No CPFP Valdemar Mattei, encontram-se, na mesma ordem: uma profissão reconhecida (na mesma proporção que o primeiro), melhorar o que já faz em seu trabalho. No CPFP Júlio de Grammont os itens subsequentes mais citados foram: mudar de ramo, ter a possibilidade de ter um trabalho e gerar renda como autônomo (na mesma proporção) e melhorar o que já faz em seu trabalho. De maneira geral, os três Centros apontaram os mesmos itens com pequenas diferenças. Por todo o contexto já colocado em relação ao Centro Júlio de Grammont, por atender uma população predominantemente feminina, a questão de ter uma profissão reconhecida colocada como primeira preocupação faz todo o sentido. Uma outra dimensão que poderia ser tratada aqui é a do trabalho autônomo. Os dois Centros que a apontaram como a mais importante, são também formados por alunos, que em suas trajetórias tiveram maior experiência em trabalhos formais, ligados à indústria. Como já citado anteriormente, esses alunos estão em processo de reconversão de suas trajetórias ocupacionais e, por isso, a possibilidade do trabalho autônomo se coloca com tanta importância nesse momento. Talvez fosse interessante destacar, aqui, o momento atual do trabalho no capitalismo, na relação entre educação e trabalho:

[...] a formação adquire um importante papel na gestão do desemprego. Nesse sentido, grande parte da literatura converge, ao associar a interpretação das ações de formação destinadas aos públicos com inserção precária no mercado de trabalho a esse novo papel da formação. O mesmo pode ser dito em relação às ações de formação profissional contínua, em relação às quais não se deve negligenciar "as tendências para o reforço das concepções utilitaristas da formação que, paradoxalmente, se articulam com a atribuição de um importante papel à formação na gestão do desemprego". (FRANZOI, 2006, p.65) 
Foi pesquisada por Centro, a intenção de atuar na área de qualificação cursada. Neste item, a permanência na área, para o PIQ II, significa a permanência na área de informática. No entanto, como esta área não visa a qualificação na maior parte dos Centros (com exceção do Centro Valdemar Mattei), as respostas dos alunos podem apresentar alguma confusão, uma vez que a qualificação profissional na área específica de atuação do Centro, se dá apenas no PIQ III.

No CPFP Valdemar Mattei, a maioria dos alunos pretende manter-se na área, apesar de este Centro apresentar uma particularidade, pois a informática pode ser utilizada como instrumento para outras profissões e ocupações. $\mathrm{O}$ fato de os alunos pretenderem continuar na área merece maior detalhamento. Dos 29 alunos do ensino fundamental do CPFP Júlio de Grammont, 21 não pretendem permanecer na área de informática, apontando outros diversos ramos pelos quais têm interesse. Desses, cinco pretendem atuar na área de estética. No ensino médio, a maior parte das alunas pretende atuar nessa área. No CPFP Armando Mazzo, entre os alunos do ensino fundamental, somente um demonstrou interesse em atuar na área de construção civil. No ensino médio, a maior parte pretende continuar na área. O quadro colocado traz um problema, uma vez que os alunos do ensino fundamental, em sua maioria, não manifestam interesse em atuar na área profissional que os Centros Públicos oferecem. Provavelmente, esses alunos cursarão o PIQ III para ter o certificado de escolaridade, sem apresentarem interesse na qualificação oferecida.

Foi observado nas respostas dos alunos que o maior interesse deles, ao cursar o PIQ, no que toca à qualificação, é o de se estabelecer como trabalhador autônomo. O sentido da qualificação ligada à profissão está mais presente entre as alunas do Centro Júlio de Grammont, mas não se manifesta notadamente nos outros Centros. Ou seja, poucos alunos vêem nos cursos de qualificação o sentido de profissão. A idéia mais presente é a de que os cursos de qualificação darão resposta imediata às suas necessidades de encontrar emprego. Percebe-se, então, que a idéia da empregabilidade está presente. Nesse sentido, o Programa tem um desafio: como trabalhar a questão da formação inicial ou continuada de trabalhadores de maneira que não se torne apenas uma resposta utilitária e de pouco efeito sobre a vida dessas pessoas. Ao estimular o empreendedorismo, o trabalho autônomo, diante de um quadro de redução do emprego formal, do qual é oriunda boa parte dos alunos pesquisados, o Programa, através de uma política compensatória, tenta responder a uma necessidade imediata, porém não pode permanecer nela. Outra possibilidade e perspectiva que o Programa pode colocar para esses alunos, consiste na articulação com outras instituições educativas, a fim de que os alunos possam prosseguir em seus itinerários. Ao mesmo tempo, uma vez que a 
qualificação, mesma que em nível técnico ou superior, não é sinônimo de emprego, é preciso condensar esforços, talvez juntamente com outras secretarias e prefeituras, no sentido de efetivas algumas das medidas já referidas nesta pesquisa, a de integrar as políticas de formação profissional às políticas de desenvolvimento econômico e geração de emprego, por meio de uma série de ações articuladas, com vistas, também, a pressionar para a implementação de uma política pública, de âmbito federal, para que isso se concretize.

Nessa direção, o documento "Carta do Recife" levanta a necessidade de iniciativas, pelo poder público municipal, que viabilizem a articulação com as políticas dos diferentes Ministérios.

Ao entrar no campo da escolaridade, observa-se que 45,5\% dos alunos pesquisados alfabetizaram-se entre sete e oito anos de idade. Antes dos sete anos, 6,3\% dos alunos, 8,8\% entre nove e dez anos, 6,3\% entre onze e doze anos, $5 \%$ entre treze e quatorze, 2,5\% depois dos vinte e um anos, e $5 \%$ não se lembram.

Com relação à série cursada antes de entrarem no Centro Público, 3,7\% não tinham concluído o primeiro segmento do ensino fundamental ( $1^{\mathrm{a}}$ a $4^{\mathrm{a}}$ séries $) ; 16,4 \%$ haviam concluído o primeiro segmento do ensino fundamental; $18,9 \%$ haviam parado de estudar na quinta série; $25,3 \%$ na sexta série; $18,9 \%$ na sétima; $7,5 \%$ na oitava. Com relação ao ensino médio $3,7 \%$ pararam no primeiro ano; $3,7 \%$ no segundo e $1,2 \%$ no terceiro.

Quanto ao número de instituições de ensino pelas quais passaram, 25,3\% afirmaram ter passado por uma única instituição antes de vir para o Centro Público; 30,3\% passaram por duas; $24 \%$ por três; $18,9 \%$ por quatro ou mais, e um aluno não respondeu.

Observa-se, neste grupo pesquisado, que a maior parte dos alunos interrompeu sua escolaridade no ensino fundamental. Poucos possuíam a escolaridade interrompida no ensino médio quando entraram no Centro Público. Esse é um fator restrito a esse grupo pesquisado, uma vez que a maior parte dos alunos pertence a turmas de ensino fundamental, e nas turmas de ensino médio pesquisadas há alguns alunos que são oriundos do PIQ II do ano anterior, uma vez que, nos Centros Públicos, a maior demanda é por PIQ III. Neste item, foi realizado o levantamento por sexo e modalidade de curso, mas os resultados não apresentaram nenhuma alteração ou característica importante que merecesse ser tratada.

Com relação às pessoas que teriam contribuído para a sua vida escolar, sem serem ligadas à escola, 55,6\% disseram não ter tido ninguém que os ajudasse. Do restante, a maior parte assinalou que os pais colaboraram, em seguida, os parentes, depois, os amigos e vizinhos, e, por último, o marido ou a esposa. 
Perguntados sobre os motivos pelos quais interromperam sua escolaridade, a opção mais citada entre os homens foi a incompatibilidade entre o horário de trabalho e estudo. A segunda mais citada foi o cansaço devido ao trabalho, acompanhadas de outras: por não haver escola próxima de casa, não ter dinheiro para condução, optou por só trabalhar, cuidar dos filhos, cuidar da casa e saúde. Entre as mulheres, a opção mais citada foi cuidar dos filhos; em seguida, cuidar da casa, incompatibilidade entre o horário de trabalho e estudo, cansaço devido ao trabalho, marido não deixava ir para a escola, saúde, os pais não deixaram. É nítido que a questão do trabalho é o maior empecilho na continuidade dos estudos no caso dos homens. No caso das mulheres, este item aparece como terceira causa de abandono de estudos, sendo que as principais são cuidar dos filhos e da casa. Situações como a proibição dos pais, ou a do marido, também foram citadas, diferentemente dos homens que não sofreram este tipo de interferência.

A questão que versa sobre os motivos que fizeram com que os alunos procurassem o Programa tinha como objetivo identificar o que mais os impulsionavam a buscá-lo, se era a certificação escolar, ou a qualificação profissional, ou o fato do Programa integrar esses dois campos. As respostas não foram muito elucidativas. Entre os homens, o item mais citado foi a obtenção do diploma escolar para melhorar no emprego, enquanto que, para as mulheres, o mais indicado foi obter tanto o diploma escolar e como o do curso profissionalizante, para melhorar a situação do emprego. Outras opções alternativas também foram bastante mencionadas pelos homens, como adquirir novos conhecimentos nas disciplinas escolares. Entre as mulheres, o segundo item mais citado foi ter um diploma para melhorar no emprego e adquirir novos conhecimentos nas disciplinas escolares. Adquirir novos conhecimentos profissionais também foi um dos mais apontados, tanto por mulheres quanto por homens.

Sobre a relação entre os conhecimentos escolares e os exigidos no trabalho, a maior parte dos alunos, tanto mulheres quanto homens, afirmam que existe essa relação. Ela é mais explícita para os alunos do ensino médio do que para os do fundamental e isso, provavelmente, se explique pelo fato de que as ocupações dos alunos que ainda não concluíram o ensino fundamental são pouco qualificadas ou não qualificadas, e os conhecimentos escolares não são exigidos no desempenho de suas funções. Sintomaticamente, foram as mulheres que mais afirmaram não haver relação entre os conhecimentos escolares e os do trabalho.

As respostas a essa questão apontam uma diversidade de situações, e mais uma vez os alunos apresentaram dificuldade em detalhar quais conhecimentos seriam necessários. Uma parte deles, tanto homens quanto mulheres, conseguiram apontar as questões de leitura, escrita 
e cálculo. Esses apontamentos foram realizados, na maioria, por alunos do ensino fundamental, o que mostra uma contradição, uma vez que também foram os alunos dessa modalidade que mais disseram não havia relação entre esses conhecimentos. Uma aluna mencionou a questão de saúde. Uma outra parte dos alunos, principalmente os homens, indicou questões referentes à melhora na parte técnica do trabalho, mas, de forma geral, sem especificá-la. Um outro grupo mencionou questões comportamentais e de relacionamento inter pessoal. De modo geral, não é claro para o grupo como se relacionam os conhecimentos escolares e os do trabalho, apesar de a afirmarem.

No que se refere à contribuição dos conhecimentos escolares para a vida, os alunos, de modo geral, mencionaram um conjunto de situações semelhantes àquelas colocadas na questão anterior, quando foi solicitada a relação entre conhecimentos escolares e trabalho. A diferença está em que, nesta questão, conseguiram detalhar melhor quais seriam os conhecimentos: a continuidade de estudos ou novas expectativas de trabalho (concurso público, vestibular, melhora das condições na procura de emprego, poder participar do programa ISO 9000, melhorar o currículo pessoal), no que as disciplinas escolares os auxiliam (melhora do vocabulário, da expressão oral e escrita, do cálculo, da cultura), na perspectiva de vida (novos cursos, atualização, conhecer os direitos e cobrá-los, ter mais informação, nova visão de mundo, desenvolver idéias, trabalhar em grupo), nos valores e postura pessoal (perder o preconceito em relação aos mais velhos, perder o medo de participar das atividades, estimulou a vontade de aprender mais, mudança em como a família e os amigos o vêem, melhora da auto estima). A esse respeito, é ainda interessante observar alguns depoimentos. Patrícia, 30 anos, CPFP Júlio de Grammont, PIQ II: "Nos cálculos que preciso para fazer uma roupa, toda área de artes, que uso para valorizar as roupas que vendo, etc". Patrícia é um exemplo de aluna que quando solicitada a se colocar, sobre a relação entre conhecimentos escolares e trabalho, não conseguiu especificá-los, e, ao ser solicitada a falar sobre os conhecimentos escolares e a sua vida, conseguiu mencionar quais seriam esses conhecimentos e como eles contribuem. Sebastiana, 34 anos, Júlio de Grammont, PIQ III: "Melhorei em tudo, tanto no trabalho quanto na minha casa com a minha família”. Rosana, 29 anos, mesma turma: "Os conhecimentos que obtive aqui mudaram e acrescentaram muito mais em minha vida social do que na escolar, mas sem desmerecer o que aprendi aqui, que espero levar para futuras provas vestibulares e quem sabe conseguir entrar numa faculdade”. Rogério, 39 anos, CPFP Armando Mazzo, PIQ III: "Na vida pessoal porque a gente se expressa melhor e também na escrita”. Anderson, 27 anos: "Aprendi que tenho direitos, que posso cobrá-los, de quem cobrar e me expresso bem melhor agora”. Eduardo, Júlio de Gramont, 39 anos, PIQ II: 
"Pois aprendi a entender os problemas dos outros e ser menos preconceituoso com pessoas de idade elevada". Maria, 34 anos: "Minha mente antes de voltar de novo para a escola parecia uma mente fechada, hoje parece que a mente abriu, e hoje não tenho medo de participar de nenhuma atividade". Cícero, 43 anos, CPFP Armando Mazzo, PIQ II: "Meus filhos me recebem diferente, meus amigos no trabalho também e eu também me vejo de outra forma". Os alunos mostram satisfação e a avaliam que a escola interfere positivamente na vida, de alguma maneira, pelos conhecimentos escolares propriamente ditos, ou enquanto espaço de convivência e construção de uma nova qualidade de entendimento do mundo e de si mesmo. Fica evidente que a educação praticada nos Centros Públicos tem contribuído para com os alunos, porém não na amplitude pretendida.

Com relação à mudança na visão que têm da sociedade a partir do que estão aprendendo no Programa, muitas indicações apareceram, apesar de 17,7\% dos alunos afirmaram que sua visão de sociedade não mudou, e 10,1\% não responderam. Entre os que responderam, é presente a dificuldade de se referirem à sociedade e, muitas vezes, repetem indicadores que se relacionam mais à vida pessoal do que à sociedade. Em primeiro lugar, mencionam a melhora no relacionamento com as pessoas, aquisição de maiores conhecimentos na área. Em seguida: união entre os colegas e conviver com os defeitos dos outros, ficou mais confiante com os estudos, ampliou os horizontes, os conhecimentos ajudam na vida e no trabalho, mudou a maneira de agir, pensar e falar, resgatou a dignidade e aprendeu a operar o computador, fez muitas amizades. Das outras respostas, citadas apenas uma vez, vale a pena ressaltar aquelas que se referem à sociedade, uma vez que as demais se repetem na mesma direção da vida pessoal. São elas: aprendeu a valorizar a política e as outras profissões, necessidade de acompanhar a evolução tecnológica, entendeu melhor a política e passou a ler jornais, aprendeu que há vários tipos de classe. Como se vê, a orientação colocada pelo terceiro eixo da proposta pedagógica, que trata da perspectiva político-ideológica, ainda é frágil junto aos alunos, uma vez que sua análise ainda se restringe ao próprio cotidiano, como se não conseguissem estabelecer relações entre eles e a sociedade. Talvez seja interessante verificar o significado da sociedade para os alunos.

Nas entrevistas realizadas com a equipe do Programa que atua nos Centros Públicos, ficou clara a perda de espaço para as discussões coletivas que tratassem dessa perspectiva. Em 2003, nas discussões sobre a proposta pedagógica do Programa, uma parte do grupo não se colocou. Os professores da profissionalização, na época, reivindicaram a permanência das aulas de "Trabalho e Cidadania", que era ministrada por professores especialistas nessa discussão, e atuavam no programa de qualificação e requalificação profissional. Essa 
reivindicação deu-se em virtude de a orientação pedagógica do Programa colocar a necessidade de ampliar e aprofundar, o tema, inclusive através de formações, a fim de que todos os professores tivessem condição de trabalhar com o eixo da perspectiva políticoideológica. Com o tempo, essa discussão se diluiu e, efetivamente, passou a ser trabalhado por um reduzido número de professores, preocupados com a questão. Hoje não se trata mais desse eixo e em seu lugar se coloca a perspectiva de tratar das questões do "mundo do trabalho", porém não há uma definição do que este termo significa.

Ao serem perguntados, sobre a ocorrência de mudanças nos planos pessoais a partir do que estão aprendendo no Programa, o mais apontado foi o desejo de fazer curso superior. Em seguida se colocam, a ampliação dos conhecimentos profissionais, buscar melhoria de vida, trabalhar como autônomo, melhorar a situação financeira, novas conquistas apesar da idade, desejo de ampliar os conhecimentos. Outros indicadores foram levantados, alguns, mais uma vez, referindo-se ao que mudou no plano pessoal, não com relação a projetos futuros, mas em relação à situação que existia anteriormente: informática trouxe dinamismo, aprendeu "coisas" que na vida ainda não tinha aprendido, viver em união e compartilhar, matemática ajuda no dia-a-dia, melhorou a auto-confiança, fez muitas atividades, desenvolveu o raciocínio. Outras, menos citadas, relacionam-se a planos futuros: especializar-se na área escolhida, antes não sabia o que fazer, conhecimentos auxiliam a colocar em prática o que gosta, com o certificado conquistar uma profissão, fazer algo diferente do que faz, conseguir um trabalho melhor, tornar-se um profissional, gostou da área escolhida, mudar de profissão.

Na questão que trata dos instrumentos aprendidos que contribuem para autonomia na busca do conhecimento, o item mais mencionado foi: conhece ou sabe buscar a legislação para abrir negócio próprio; dois itens ocupam o segundo lugar, na mesma proporção: buscar informações em jornais, revistas, dicionários, livros, etc e reunir informações de diferentes fontes e elaborar uma conclusão própria do conhecimento procurado. Em seguida, montar um currículo e enviar aos locais adequados, saber onde buscar seus direitos ao sentir-se prejudicado em alguma situação; e, o menos indicado, acessar a Internet e buscar a informação necessária.

Na seqüência, quando perguntados sobre a contribuição da escola na construção da autonomia, 44,3\% dos alunos não conseguiram definir e 6,3\% afirmaram que a escola não ajudou. Os que se colocaram, apontaram o seguinte: trabalho com a informática e Internet, informações passadas pelos professores, melhorou a leitura, conhecimentos e atualização, passou a ler e escrever mais, sabe onde pesquisar o que é necessário, questionamentos colocados pela escola, leitura de jornais e revistas. Entre os menos citados estão: auxílio da 
matemática e do português, trabalhar em grupo, informações sobre os direitos, montagem de currículo, debates, elaboração de projetos e entendimento das leis.

Com relação aos motivos que prejudicam a freqüência à escola, a maioria, tanto homens quanto mulheres, disse não haver nada que prejudique. Entre os homens, o motivo mais apontado foi o horário de trabalho, seguido por saúde, falta de dinheiro para o transporte, problemas familiares, distância entre a escola e a casa. No caso das mulheres, o mais citado foi falta de quem cuide dos filhos, distância entre a escola e a casa, problemas familiares, distância entre a escola e o trabalho, falta de dinheiro para o transporte, horário de trabalho, responsabilizar-se por crianças pequenas em casa, idade, horário das aulas.

As soluções apontadas pelos alunos foram: auxílio das empresas de transporte ou que o ônibus da escola fizesse um percurso menos longo, colaborar com o aluno no dia seguinte à falta, começar a aula mais tarde, ter mais escolas profissionalizantes. Foram apontadas, também, soluções pessoais: auxílio dos amigos, comprar um carro, pagar uma babá.

A referência que os alunos fazem ao ônibus que circula entre os Centros mostra, conforme o que já havia sido mencionado, que a oferta do transporte pela Secretaria de Educação não responde às necessidades dos alunos, o que faz com que muitos escolham os Centros e seus cursos pela proximidade, e não por interesse ou desejo.

As perspectivas para os próximos dois anos, colocadas pelos homens, foram as seguintes, na ordem: concluir a modalidade em curso e ingressar no próximo nível, fazer um curso técnico, estar atuando na área de qualificação cursada, estar trabalhando (não especificou). Entre as mulheres: concluir a modalidade em curso, e ingressar no próximo nível foram as mais citadas; em seguida: estar em uma situação melhor que hoje (sem especificar), fazer outros cursos na área ou fora dela, estar trabalhando e realizada no trabalho.

Para os alunos do PIQ III, o nível superior não é uma possibilidade concreta para a maioria. Há alguns relatos de alunos nos Centros sobre terem conseguido bolsas de estudo em faculdades privadas, mas é um número bastante pequeno. Dessa maneira, cursar a faculdade refere-se mais a um desejo do que a uma possibilidade concreta.

Para os próximos cinco anos, os homens apontaram: estar melhor que hoje (sem especificar), estar em um emprego estável, estar estabelecido na área, no mesmo ramo, estar fazendo faculdade, estar trabalhando (no mesmo ou em ramos diferentes). De acordo com as mulheres, estar fazendo faculdade é o primeiro item a ser colocado, seguido por estar melhor que hoje (sem especificar), estar trabalhando na mesma área, como autônoma, mudar de ramo, estar trabalhando e realizada profissionalmente. 
A preocupação fundamental de todos é o trabalho. Estando ou não ligados às suas áreas cursadas, o que traçam como perspectiva é estar trabalhando. No caso dos homens, apesar de na questão anterior terem afirmado (a maioria) a intenção de trabalhar como autônomos, nesta questão, isso não aparece. Referem-se ao emprego estável. A busca do trabalho autônomo não é um desejo, mas a possibilidade diante do que não pode ser encontrado, o emprego. No caso das mulheres, essa intenção não se coloca, mas a questão do trabalho autônomo sim. Talvez essa situação ocorra pelo fato de a maioria dos homens serem oriundos de situações de trabalho formal, e as mulheres não, o que faz com elas se deparem com um quadro de crescente precarização do trabalho, e só vejam, como alternativa possível, o trabalho autônomo. Outra hipótese, a de que marcadas por suas trajetórias, não consigam vislumbrar essa possibilidade em sua condição de classe e de gênero.

Com todas as dificuldades enfrentadas pelos alunos e alunas, a grande maioria projeta situações de melhoria para sua vida. Porém, como pode ser observado, muitas vezes isso se traduz em desejo, vontade, esperança, do que propriamente um projeto de vida estruturado. Alguns depoimentos de alunos ilustram bem isso, ao descreverem sua perspectiva para os próximos dois e cinco anos. No CPFP Armando Mazzo: Anderson, 27 anos, PIQ III: “Ter minha casa própria e um cargo de prestígio e importância, estabilidade financeira. Bem definida!!!”. Rogério, 39 anos, PIQ III: “Estar trabalhando até me estabilizar”. Jorge, 47 anos, PIQ III: "Seguir em frente de cabeça erguida, aprender mais e mais no vestibular até a faculdade. Ser muito profissional nesta área e muito responsável nas minhas obrigações". Milton, 49 anos, PIQ III: “Ainda não pensei nisso. Pretendo estar melhor do que hoje". Roberto, 37 anos, PIQ III: "Estar formado em técnico em eletrônica e estar exercendo a profissão. Pretendo estar atuando na área de eletrônica e quem sabe estudando engenharia". No CPFP Júlio de Grammont, alguns alunos se colocaram da seguinte maneira: Maria, 20 anos, PIQ II: "Estar pronta para enfrentar qualquer tipo de trabalho. Realizada, trabalhando no eu gosto e fazendo faculdade". Darci, 41 anos, PIQ II: “Terminar meus estudos, ir buscar uma profissão melhor. Eu pretendo conseguir um trabalho seguir adiante, crescer profissionalmente". Maria, 38 anos, PIQ II: “ Fazer o colegial e fazer um curso de enfermagem ou estética e começar uma vida nova. Lutei para estar melhor que hoje trabalhando e recebendo um salário justo". Sebastiana, 34 anos, PIQ III: "Estar realizada profissionalmente. Pretendo estar exercendo esta profissão que adquiri aqui neste Centro". Maria, 34 anos, PIQ II: "Terminar meus estudos e poder participar de vestibulares e depois cursar uma faculdade. Pretendo ter terminado a faculdade e exercer minha profissão". No CPFP Valdemar Mattei não é diferente. Lucas, 46 anos, PIQ III: “Fazer o cursinho e fazer 
faculdade de medicina. Estar no $3^{\circ}$ ou $4^{\circ}$ ano da faculdade". Antonio, 54 anos, PIQ III: "Prestar vestibular, conseguir uma vaga e estudar fisioterapia”. José, 49 anos, PIQ II: “A minha esperança é terminar a $8^{\mathrm{a}}$. Para saber tudo isso é só esperar o tempo passar”. Karina, 16 anos, PIQ II: "Terminando meus estudos. Pretendo estar em um bom emprego e formada". Franzoi também verificou o mesmo processo junto aos alunos do PEQ do Rio Grande do Sul:

Projetam um futuro profissional sem nenhum ou com poucos recursos que lhes dêem sustentação: seus projetos são difusos, fazendo com que se tornem remotos, parecendo-se mais com desejos do que com projetos exeqüíveis. (2006, p.101)

Em termos de perspectiva, o que está mais ao alcance desses alunos em relação àquilo que projetam para si é a conclusão do ensino básico, caso consigam concluir o Programa. Alguns cursos oferecem maior possibilidade de preparo para um trabalho imediato, autônomo, e talvez aí haja alguma possibilidade de resolver, parcialmente, o que eles esperam, uma vez que a estabilidade e a realização profissional desejada dependem de fatores que não estão sob o seu controle. $\mathrm{O}$ que os alunos de fato conseguem realizar, ao deixar o Programa, é o que pretendia verificar a pesquisa de egressos, iniciada pelo Observatório da Educação e do Trabalho. No entanto, esse estudo ainda não ocorreu de forma sistemática.

De modo geral, até por não ter uma pesquisa de egressos concluída, não é possível avaliar qual interferência do PIQ na vida das pessoas que passaram por ele. Além daquelas anunciadas pelos próprios alunos, em termos pessoais e subjetivos, e nas falas dos professores e diretoras que relataram situações de elevação de auto-estima, algumas histórias pontuais de alunos que conseguiram se estabelecer como autônomos, principalmente na área de estética, e de outros que ingressaram em faculdades da região, não há como aferir o quanto o Programa atingiu seus objetivos.

O que se verifica nos relatos dos alunos é que a idéia central do itinerário formativo não foi incorporada por eles, uma vez que não conseguiram projetar, de maneira clara, a relação do que estão cursando na área de qualificação profissional e suas perspectivas concretas de continuidade. A maioria, também, não se referiu ao curso superior como continuidade de sua formação atual, no campo profissional. Dessa maneira, pode-se dizer que vêem os cursos de qualificação como, talvez, algo que se faz enquanto algo melhor não surja, e, efetivamente, o DET não conseguiu ainda estabelecer uma articulação institucional para que fosse diferente. 


\section{CONSIDERAÇÕES FINAIS}

Nos objetivos do Programa fica clara a opção por atender a população que se encontra em situação de precariedade social e econômica. No entanto, apesar de ser dirigido aos munícipes, de forma ampla, as condições para que estes tenham acesso ao Programa ocorrem a partir de uma delimitação de público que será atendido. Por um lado há a escolha política da administração municipal de oferecer o serviço à população que apresenta baixa escolaridade e, por outro, as possibilidades existentes de financiamento do Programa restringem sua oferta.

A delimitação do público que será atendido e suas características apresentam duas questões para reflexão: como atender a esta população sem cair na antiga idéia de "assistir aos desvalidos", de certa forma resgatada pelo modelo de educação profissional proposto no governo FHC, e como propor a formação profissional de maneira que contribua com a emancipação dos trabalhadores, a partir de uma perspectiva de classe.

A esse respeito, é preciso fazer algumas considerações. Paiva (1973), coloca dois entendimentos diferenciados de educação popular. Esta pode ser entendida como a educação oferecida a toda a população, a todas as camadas da sociedade, de forma gratuita e universal. Outra concepção diz respeito à educação destinada às "camadas populares", que contempla a instrução elementar e o ensino técnico-profissional para os já mencionados "desvalidos" da sociedade. Beisiegel (1974) mostra, por sua vez, como, nas proposições do Estado, a educação popular pode ser utilizada como instrumento de sustentação política, ou se antecipar à população nas suas necessidades, a partir dos interesses ideológicos presentes no momento.

Nessa perspectiva, as propostas ou diretrizes para a educação de adultos e a formação profissional, elaboradas por administrações públicas de corte popular ou por organizações sociais vinculadas ao campo de luta dos trabalhadores, podem ser entendidas como projetos de educação que expressam ideologias de classe, na tensão entre capital e trabalho.

Assim, de acordo com o público ao qual se destina, pode ser entendida como educação popular, não no sentido de ser uma política voltada para a contenção das insatisfações populares ou que contribua na definição de seu lugar social subalterno, mas como uma espécie de condensação (ainda que limitadamente, na forma de programa) dos interesses da classe trabalhadora, expressas através de suas organizações.

Elementos importantes foram apontados por organizações de trabalhadores e movimentos sociais, muitos deles incorporados ao Programa, pelo menos em sua intencionalidade: o entendimento de que a formação profissional é um direito tanto quanto a 
educação básica; a necessidade de integrar esses dois processos formativos, com vistas a superar uma visão de formação profissional instrumental e fragmentada voltada só ao mercado de trabalho; a relação entre educação e trabalho, tanto em sua perspectiva social e política, através da oferta de políticas integradas de educação, geração de emprego e desenvolvimento econômico e social, quanto em seu aspecto politécnico, da relação entre os conhecimentos científicos, técnicos, culturais, instrumentais e tácitos dos trabalhadores; a oferta de trajetórias de formação que propiciem a elaboração de um projeto pessoal de progressão educacional e profissional; e a compreensão da perspectiva ontológica do trabalho, como princípio educativo.

Diante de um contexto de longo tempo, de políticas focais estabelecidas pelos governos neo liberais, que não consideram em suas elaborações a Educação de Jovens e Adultos, justamente por já lhe determinar seu lugar como classe social, há a necessidade efetiva e concreta de incorporar ao campo dos direitos essa modalidade da educação. E o trabalho, por ser o elemento central da constituição da vida adulta, não pode estar desvinculado desta defesa, seja no campo da política econômica, seja no campo da educação.

No entanto, a proposta de educação popular presente no Programa encontra obstáculos institucionais, uma vez que a política municipal encontra-se subordinada à configuração de forças existentes nas diferentes instâncias governamentais - Municipal, Estadual e Federal. No âmbito das disputas existentes no governo federal, o movimento das políticas focalizadas e duais fez com que os projetos de EJA e de formação profissional integrada à educação básica resistissem através da própria dinâmica de embates entre a pressão social e a pressão advinda do Estado. Assim, o problema de financiamento do PIQ só pode ser resolvido, não no interior de suas próprias ações, mas justamente por meio de pressão exercida pela sociedade organizada, para que, em nível político e institucional, fossem rompidas essas determinações.

Esse movimento conseguiu avançar e superar alguns obstáculos com a formalização do Decreto 5154/04, na transformação do FUNDEF em FUNDEB, e precisa continuar, promovendo a revisão da LDB, nos Parâmetros e Diretrizes Curriculares, e mudanças no Sistema S. O PIQ, nesse contexto, pode, através de sua experiência institucional, ser uma referência para as instâncias municipais de poder, principalmente para as democráticas e populares, e, dessa maneira, exercerem pressão para a implementação de políticas públicas nacionais de educação. 
É preciso considerar, porém, que em uma administração que se coloca como democrática e popular, a gestão interna do Programa não pode abdicar daquilo que é mais caro à educação popular: a participação dos sujeitos sociais como condição de construção de uma nova sociabilidade. Nesse campo, as pessoas responsáveis pela gestão do Programa abriram mão de um princípio fundamental que está nas raízes de sua proposição, e que pode ter sido um dos elementos que colaborou para que alguns de seus objetivos não fossem atingidos. Inclusive, com a participação de seus agentes, principalmente alunos, a mobilização da população em torno de reivindicações pelo direito à educação, poderia ser um instrumento importante de pressão social junto ao governo estadual e federal, na busca de saídas para as dificuldades existentes.

Não se está afirmando que o poder municipal deveria tutelar essa organização, mas que uma efetiva participação nas orientações do Programa poderia contribuir no entendimento do que significa essa política. Pode-se citar, como exemplo, a definição do papel das entidades conveniadas no PIQ. As entidades que compõem o Programa são representativas das reivindicações dos trabalhadores, com maior ou menor vínculo partidário, maior ou menor experiência em formação profissional e educação, mas de alguma forma compuseram o rol de indicações do que seria uma política pública voltada às necessidades da classe trabalhadora. No entanto, pelos relatos colhidos, sua participação assemelha-se mais a uma terceirização da função do Estado. O que exige atenção.

Nessa direção, como afirma Danilo Streck (2006), os grupos ligados à educação popular depositaram expectativas de que teriam suas pautas atendidas, por ocasião da ascensão do Partido dos Trabalhadores ao poder em nível nacional. Na plataforma deste partido, bem como na de outros partidos de esquerda, encontram-se muitas das reivindicações propostas em encontros e derivadas das práticas de educação popular. Pode-se dizer, no entanto, que essas expectativas não se manifestaram somente em nível nacional, mas também no local. Segundo o autor, a educação popular aproximou-se do lugar onde se gera o discurso hegemônico, e isso traz vantagens e riscos. A vantagem é ser reconhecida, incorporar-se ao fluxo da política e da pedagogia, e o risco consiste no comprometimento de sua identidade.

O PIQ, por ser um programa que traz em si as diretrizes de movimentos sociais populares e suas propostas, e estar inscrito na estrutura estatal, no poder público municipal, talvez padeça exatamente desse conflito. Por isso, é preciso que o Programa dialogue com os trabalhadores, no sentido de atender suas necessidades, embora esteja circunscrito às limitações burocráticas e institucionais. Vem daí a advertência de CORD1, ao colocar que o Programa não considerou, em sua formulação, a possibilidade de ousar e se manteve dentro 
dos limites de um modelo de escolarização que não responde adequadamente às necessidades daqueles que são trabalhadores.

É preciso pensar sobre as formas e as instâncias de atuação dos participantes do Programa, principalmente os alunos. Como essa política de educação de adultos trabalhadores pode estruturar a organização do ensino (metodologias educacionais e de gestão) com efetiva participação dos trabalhadores, usuários de suas propostas, seja em sua duração, na forma de organização, na discussão da proposta currículo e dos itinerários formativos? Quais movimentos, ações educativas, são necessários para que os trabalhadores, em um processo de educação, estabeleçam relações e consigam pensar e propor saídas para sua situação? Como superar o campo das políticas compensatórias e de formação para o desemprego, com uma proposta de política pública que não se limite à formação instrumental, dirigida ao autoemprego? Uma forma de avançar nessa condição consiste na construção de itinerários formativos, o que se dá no nível da articulação do sistema de educação. Faz-se também necessária a articulação das políticas federais e estaduais com as municipais, no que toca a educação e trabalho, além da necessária e urgente articulação dos níveis e modalidades da educação, a fim de efetivamente propiciar aos trabalhadores o acesso ao conhecimento científico, técnico e humano.

Nesse campo da articulação de políticas, a sobreposição de programas também é uma questão que do ponto de vista nacional necessita ser reorganizada. Outra dimensão, que diz respeito mais propriamente ao campo pedagógico, deve considerar que, na formação inicial e continuada de trabalhadores, a relação entre educação e trabalho deve caminhar na direção do estabelecimento de relações entre os conhecimentos tácitos, instrumentais, técnicos, científicos e humanos, que superem a ação imediata do trabalho. Nesse sentido, mais que metodologias pedagógicas, o que é necessário é a discussão de um currículo que integre essas dimensões.

Por fim, o Programa apresenta avanços bastante importantes, defendidos pelas instâncias do governo municipal, e tem encontrado eco, de forma ainda incipiente, nas orientações do governo federal, e aí reside a possibilidade de sua consolidação como política pública de Estado. Esta vinculação e a própria mudança que vem ocorrendo na instância federal e não acontece sem embates e sem demora.

Internamente, o PIQ não pode perder aquilo que lhe é inerente, por tudo o que já foi colocado. É preciso que, em sua institucionalização, não se afaste dos princípios que o fundaram. A superação das dificuldades externas e internas, se elas ocorrerem, pode apontar uma perspectiva de política pública para a Educação de Jovens e Adultos e para o ensino 
profissional, que, articulado com outras políticas, sinalize a possibilidade de um processo de educação e progressão funcional de importância significativa para os trabalhadores e as trabalhadoras. Caso essas dificuldades não sejam superadas, corre-se o risco de ter a reprodução de modelos educacionais já existentes e que são limitados quanto ao que oferecem à classe trabalhadora. 


\section{REFERÊNCIAS BIBLIOGRÁFICAS}

ABRAMO, L. "Cadeias produtivas, segmentação de gênero e novas formas de regulação: notas metodológicas a partir de uma experiência de pesquisa". In: GYTAHI, L.; LEITE, Márcia de P. Novas tramas produtivas: uma discussão teórico-metodológica. São Paulo: Editora SENAC São Paulo, 2005. p.87-103.

ABRAMO, Perseu. "Pesquisa em Ciências Sociais". In: HIRANO, Sedi (Org.). Pesquisa Social: Projeto Planejamento. São Paulo: T. A.Queiroz, 1979.

ACCA, Rogério dos S. A dinâmica produtiva recente da metrópole paulista: das perspectivas pós-industriais à consolidação do espaço industrial de serviços. Rio de Janeiro, 2006. Disponível em: $<$ http://www.scielo.br/scielo.php?script=sci_arttext\&pid=S001 1-52582006000100006\&lng=\&nrm=iso\&tlng=>. Acesso em: 18 de julho de 2006.

ARROYO, M. "Trabalho - educação e teoria pedagógica”. In: FRIGOTTO, G. (Org.). Educação e crise do trabalho: perspectivas de final de século. $4^{\mathrm{a}} \mathrm{ed}$. Petrópolis: Vozes, 1998. p.138-165.

BEISIEGEL, Celso de Rui. “A educação de adultos em São Paulo após a campanha”. In: Estado e educação popular: um estudo sobre a educação de adultos. São Paulo: Pioneira, 1974. p.157-182.

- “Considerações sobre a política da União para a educação de jovens e adultos analfabetos”. Revista Brasileira de Educação, ANPED, nº 4, 1997a.

. "A política de educação de jovens e adultos analfabetos no Brasil". In: OLIVEIRA, D. (Org.). Gestão Democrática da Educação: desafios contemporâneos. Rio de Janeiro: Vozes, 1997b. p.207-245.

Questões de atualidade na educação popular. Ensino fundamental de jovens e adultos analfabetos ou pouco escolarizados. 22a ANPED. Caxambu: São Paulo, 1999.

BERNARDO, P. C. Projeto de educação de trabalhadores: a educação enquanto direito subjetivo de jovens e adultos em Belo Horizonte. Dissertação (Mestrado em Educação), Faculdade de Educação, Universidade de São Paulo, São Paulo, 2005. 
BRANDÃO, Márcia Serôa da Mota. "Panorama histórico da educação profissional no Brasil". In: LEITE, Elenice Monteiro; SOUZA, Francisco Heitor de Magalhães (Orgs.). Centros públicos de educação profissional: teorias, propostas, debates e práticas. Brasília: Editora Universidade de Brasília, 2002. p.125-136.

BRASIL. Decreto $\mathbf{n}^{0}$ 2.208, de 17 de abril de 1997. Brasília, MEC. Regulamenta o $\S 2^{\circ}$ do art.36 e os arts. 39 a 42 da Lei $n^{\circ}$ 9.394, de 20 de dezembro de 1996, que estabelecem as diretrizes e bases da educação nacional. Diário Oficial [da] República Federativada Brasil, Brasília, DF, 17 abr. 1997.

Conselho Nacional de Educação. Câmara de Educação Básica. Parecer nº 16/99 Diretrizes curriculares nacionais para a Educação Profissional de Nível Técnico. Publicado no Diário Oficial da União de 26/11/1999. Disponível em: $<$ http://portal.mec.gov.br/setec/arquivos/pdf/ceb016.pdf>. Acesso em: 24 de janeiro de 2008. Conselho Nacional de Educação. Câmara de Educação Básica. Parecer CEB no 11/2000. Relator: Carlos R. J. Cury. Brasília, 2000.

Ministério da Educação/ INEP. Educação de jovens e adultos no Brasil (19861998). Coordenação de S. Haddad. Brasília, 2002.

Subsídios para o processo de discussão da proposta de anteprojeto de lei orgânica da Educação Profissional e Tecnológica. Brasília, SETEC/MEC, 2004a.

Decreto $\mathbf{n}^{0}$ 5.154, de 23 de julho de 2004. Regulamenta o $\S 2^{\circ}$ do art. 36 e os arts. 39 a 41 da Lei no 9.394, de 20 de dezembro de 1996, que estabelecem as diretrizes e bases da educação nacional e dá outras providências. Brasília, MEC, 2004b.

Comissão Interministerial de Certificação Profissional. Sistema Nacional de Certificação Profissional. Proposta governamental. Brasília, agosto de 2005. Disponível em: <http://portal.mec.gov.br/setec/arquivos/pdf/certifica_minuta.pdf>. Acesso em: 25 de janeiro de 2008 .

BRAVERMAN, Harry. Trabalho e capital monopolista: a degradação do trabalho no século XX. Rio de Janeiro: Guanabara, 1987.

BRYAN, N. A. P. Taylorismo: gestão tecnocrática e padronização do trabalhador. Campinas: UNICAMP, 1992. 
CEEP. Disponível em: <http://www.ceep.org.br/?q=tx-histor\&PHPSESSID=95e04f93a80b04 1 ccd47111cf7166d32>. Acesso em: 20 de julho de 2006.

CENTRAL ÚNICA DOS TRABALHADORES - CUT. Informa CUT: Resoluções. $7^{\text {a }}$ Plenária Nacional Zumbi dos Palmares - 30 de agosto a 2 de setembro de 1995. São Paulo, 1995.

$5^{\circ}$ CONCUT: Resoluções. São Paulo, 1995.

CONCEIÇÃO, J. J. "Região do ABC: Breve histórico". In: SINDICATO DOS METALÚRGICOS DO ABC. Subseção DIESSE. Grande ABC em números. São Paulo, 2003. p.253-268.

COSTA, C. "Do PLANFOR ao PNQ: mundo do trabalho, qualificação profissional e políticas públicas”. In: OLIVEIRA, R. V. (Org.). Qualificar para quê? Qualificação para quem? Do global ao local: o que se espera da qualificação profissional hoje? São Paulo: Fundação UNITRABALHO; Campina Grande: EDUFCG, 2006. p.131-150.

CUNHA, Luiz A. O ensino industrial-manufatureiro no Brasil: origem e desenvolvimento. Biblioteca virtual Herbert de Souza, Faculdade Latino-americana de Ciências Sociais (FLACSO), Sede Acadêmica Brasil (FLACSO/ Brasil), 2000. Disponível em: 〈http://www.flacso.org.br/data/biblioteca/392.pdf>. Acesso em: 10 de janeiro de 2007.

. "As agências financeiras internacionais e a reforma brasileira do Ensino Técnico: a crítica da crítica". In: ZIBAS, Dagmar; AGUIAR, Márcia; BUENO, Maria Sylvia (Orgs.). O Ensino Médio e a Reforma da Educação Básica. Brasília: Plano Editora, 2001. p.105-134.

DIEESE. Anuário dos Trabalhadores 2005. 6 ed. São Paulo, 2005.

ESCOLA SINDICAL SÃO PAULO. Disponível em: 〈http://www.escolasp.org.br/apres.htm>. Acesso em: 22 de janeiro de 2008.

FELIX, F.; MORAES, I. N. de; AGUIAR, F. "Trabalhadores e educação: organização e construção da cidadania". In: SINDICATO NACIONAL DOS DOCENTOS DAS INSTITUIÇÕES DE ENSINO SUPERIOR. Cadernos Andes no 10: Educação e Trabalho. Brasília, 1993. p.7-17. 
"Diretrizes para uma política de formação profissional da CUT". In: SINDICATO NACIONAL DOS DOCENTOS DAS INSTITUIÇÕES DE ENSINO SUPERIOR. Cadernos Andes no 10: Educação e Trabalho. Brasília, 1993. p.18-26.

FERRETI, Celso J. Opção trabalho: trajetórias ocupacionais de trabalhadores das classes subalternas. São Paulo: Cortez, 1988.

Uma nova proposta de orientação profissional. 3ªed. São Paulo: Cortez, 1997.

FRANZOI, Naira L. Entre a formação e o trabalho: trajetórias e identidades profissionais. Porto Alegre: Editora da UFRGS, 2006.

FRIGOTTO, Gaudêncio (Org.). Educação e crise do trabalho: Perspectivas de final de século. 4 ed. Rio de Janeiro: Vozes, 1998.

; CIAVATTA, M.; RAMOS, M. "O trabalho como princípio educativo no projeto de educação integral de trabalhadores”. In: COSTA, Hélio da; CONCEIÇÃO, Marinho da. Educação Integral e Sistema de Reconhecimento e certificação Educacional e Profissional. Vol.1. São Paulo: CUT, 2005. p.19-62.

- "A gênese do decreto n. 5.154/2004. Um debate no contexto controverso da democracia restrita". Revista Eletrônica do Núcleo de Estudos Trabalho e Educação. NEDATE-UFF, 2005. Disponível em: <www.uff.br/trabalhonecessario>.

FUNDAÇÃO SEADE. Disponível em: 〈http://www.seade.gov.br/produtos/perfil/perfil.php>. Acesso em: 10 de janeiro de 2008.

GADOTTI, M. Estado e educação popular: educação de adultos em São Paulo (Brasil). São Paulo, 1992. Disponível em: <http://www.paulofreire.org/Moacir_Gadotti/Artigos/ Portugues/Educacao_Popular_e_EJA/Estado_educ_pop_1992.pdf >. Acesso em: 21 de janeiro de 2008.

GOMES, Carlos M. et. al. Trabalho e conhecimento: dilemas na educação do trabalhador. $4^{\mathrm{a} e d . ~ S a ̃ o ~ P a u l o: ~ C o r t e z, ~} 2002$.

GYTAHI, L.; LEITE, Márcia de P. Novas tramas produtivas: uma discussão teóricometodológica. São Paulo: Editora SENAC São Paulo, 2005.

HIRATA, H. Nova divisão sexual do trabalho? Um olhar voltado para a empresa e a sociedade. São Paulo: Boi Tempo Editorial, 2002. 
IBGE - Instituto Brasileiro de Geografia e Estatística. Síntese de indicadores sociais. 2005. Disponível em: <http://www.ibge.gov.br/home/estatistica/populacao/condicaodevida/indicado resminimos/sinteseindicsociais2005/indic_sociais2005.pdf>. Acesso em: 19 de julho de 2006.

INEP - Instituto Nacional de Estudos e Pesquisas Educacionais. Geografia da Educação Brasileira. Brasília, 2001.

INSTITUTO DE PESQUISAS TECNOLÓGICAS. Relatório técnico n 56870. Proposições para o Desenvolvimento Econômico do Município de Santo André. São Paulo, 2001.

LEÃO, Geraldo M. P. Pedagogia da cidadania tutelada: lapidar corpos e mentes. Uma análise de um programa federal de inclusão social para jovens pobres. Tese (Doutorado em Educação), Faculdade de Educação, Universidade de São Paulo, São Paulo, 2004.

LIMA, Almerico B. (Org.). Educação popular na Amazônia - as experiências da CUT em qualificação profissional. Roraima: Editora Gráfica Imediata, 2001.

MACHADO, L. R. S. “A propósito dos centros públicos de educação profissional”. In: LEITE, E. M.; SOUZA, F. H. M. Centros públicos de educação profissional: teorias, propostas, debates e práticas. Brasília: Editora de Universidade de Brasília, 2002. p.83-101.

MANFREDI, S. M. “A educação popular no Brasil: uma releitura a partir de Antonio Gramsci”. In: BRANDÃO, C. R. (Org.). A questão política da educação popular. São Paulo: Brasiliense, 1980. p.40-61.

; BASTOS, S. "A formação de formadores na Escola Sindical São Paulo". In: SECRETARIA NACIONAL DE FORMAÇÃO CUT. Núcleo Temático Educação do Trabalhador. Identidade e Diversidades. Formação sindical em debate $\mathbf{n}^{\mathbf{0}}$ 1: Sistematização de experiências de formação de educadores sindicais desenvolvidas pelas escolas da CUT (1988-1995). São Paulo, 1998. p.24-35.

Educação profissional no Brasil. São Paulo: Cortez, 2002.

MARX, K. Manuscritos Econômico-Filosóficos. Tradução de Artur Morão. Lisboa: Edições $70,1989$.

MATTEO, Miguel. Indústria lidera crescimento no ABC. Observatório Econômico, Boletim $n^{\circ}$ 7. Secretaria de Desenvolvimento Econômico e Ação Regional, Santo André, São Paulo, 2005. 
MEHEDFF, N. G. "A nova institucionalidade da educação profissional e a questão dos centros públicos". In: LEITE, E. M.; SOUZA, F. H. M. Centros públicos de educação profissional: teorias, propostas, debates e práticas. Brasília: Editora de Universidade de Brasília, 2002. p.17-31.

MELLO, João Manuel C. de; NOVAIS, Fernando A. "Capitalismo tardio e sociabilidade moderna". In: NOVAIS, Fernando A. (Org.). História da vida privada no Brasil Contrastes da intimidade contemporânea. São Paulo: Companhia das Letras, 1998. p.559606.

MORAES, Carmen Sylvia Vidigal. "Política e formação Profissional no Brasil e em alguns países europeus”. In: Anais do IV Encontro Nacional da ABET. São Paulo, 1997.

- “A relação trabalho-educação e o 'novo conceito de produção': algumas considerações iniciais". In: MORAES, Carmen S. V.; FERRETI, Celso (Coords.). Diagnóstico da Formação Profissional - Ramo Metalúrgico. São Paulo: CNM/CUT e Rede Unitrabalho, 1999. p.15-27.

; LOPES NETO, Sebastião. Políticas públicas para a educação de jovens e adultos. A educação de jovens e adultos e o mundo do trabalho. Texto apresentado no Seminário de Educação de Jovens e Adultos. São Paulo, 2000.

. "O que há de novo na Educação Profissional no Brasil". Trabalho e Educação. Revista do NETE - FaE/UFMG, nº.8, jan./ju. 2001.

A socialização da força de trabalho: instrução popular e qualificação profissional no estado de São Paulo (1873 a 1934). Bragança Paulista: EDUSF, 2003.

; PONTUSCHKA, N. N.; KRUPPA, S. M. P. Projeto "Educação de Adultos trabalhadores: metodologias de ensino aprendizagem, itinerário formativo e capacitação de professores". Relatório Final FAPESP. Dezembro de 2007.

NETO LOPES, S.; MORAES, C. S. V. "Contribuição para a definição de uma política de formação profissional da CUT”. In: SINDICATO NACIONAL DOS DOCENTOS DAS INSTITUIÇÕES DE ENSINO SUPERIOR. Cadernos Andes n 10: Educação e Trabalho. Brasília, 1993. p.27-38.

NOGUEIRA, Marco Aurélio. Um Estado para a sociedade civil: temas éticos e políticos da gestão democrática. São Paulo: Cortez, 2004. p.263. 
OLIVEIRA, R. V. de. "Qualificação profissional: um campo em disputa”. In: OLIVEIRA, R. V. de. (Org.). Qualificar para quê? Qualificação para quem? Do global ao local: o que se espera da qualificação profissional hoje? São Paulo: Fundação UNITRABALHO; Campina Grande: EDUFCG, 2006. p.12-26.

PAIVA, V. P. Educação popular e educação de adultos: contribuição à história da educação brasileira. São Paulo: Edições Loyola, 1973.

PREFEITURA DE SANTO ANDRÉ. Secretaria de Educação e Formação Profissional. Estação Gente - Educação Inclusiva-Profissionalizante. Santo André, São Paulo, 2000.

- Secretaria de Educação e Formação Profissional. Departamento de Educação do Trabalhador. Projeto de implantação de itinerário formativo. Santo André, São Paulo, 2001.

- Secretaria de Desenvolvimento Econômico e Ação Regional. Observatório Econômico, Boletim no 2. Ano 1. Santo André, São Paulo, 2003a.

- Secretaria de Educação e Formação Profissional. Departamento de Educação do Trabalhador. Proposta Pedagógica do PIQ. Santo André, São Paulo, 2003b.

. Secretaria de Desenvolvimento Econômico e Ação Regional. Perfil do Trabalhador Informal em Santo André. Santo André, São Paulo, 2004.

- Secretaria de Desenvolvimento Econômico e Ação Regional. Observatório Econômico, Boletim no 8. Ano 3. Santo André, São Paulo, 2005.

- Secretaria de Desenvolvimento Econômico e Ação Regional. Observatório Econômico, Boletim no 11. Ano 4. Santo André, São Paulo, 2006.

SANTO ANDRÉ. Lei 8.142, de 22 de dezembro de 2000. Autoriza a celebração de convênio entre o Município de Santo André e entidades assistenciais sem fins lucrativos. Diário do Grande ABC. $n^{\circ}$ 10894. Santo André, 23 de dezembro de 2000.

Lei 8.804, de 13 de dezembro de 2005. Dispõe sobre a criação do Programa Integrado de Qualificação. Diário do Grande ABC. n 12712. Santo André, 14 de dezembro de 2005. 
Observatório da Educação e do Trabalho. Secretaria de Educação e Formação Profissional. Programa Integrado de Qualificação - PIQ: A Teoria do Programa e a Implementação. Santo André, São Paulo, 2006.

SEMINÁRIO NACIONAL: A QUALIFICAÇÃO PROFISSIONAL COMO POLÍTICA PÚBLICA. Santo André, São Paulo, 2002.

SEMINÁRIO NACIONAL: A QUALIFICAÇÃO PROFISSIONAL - ENTRE O DIREITO À EDUCAÇÃO E O MERCADO DE TRABALHO. Recife, 2003.

SINDICATO DOS METALÚRGICOS DO ABC. Subseção DIESSE. Grande ABC em números. São Paulo, 2003.

SOARES, Leôncio J. G. “As políticas de EJA e as necessidades de aprendizagem dos jovens e adultos”. In: RIBEIRO, Vera Masagão (Org.). Educação de jovens e adultos: novos leitores, novas leituras. São Paulo: Mercado de Letras, 2001. p.201-221.

SOARES, V. G. “Centro Experimental Público de Formação Profissional em São Paulo”. In: Centros públicos de educação profissional: teorias, propostas, debates e práticas. Brasília: Editora de Universidade de Brasília, 2002. p.403-410.

SOUZA, R. S. A política educacional da administração do partido dos trabalhadores em Santo André: Educação de Jovens e Adultos. Dissertação (Mestrado em Educação), Faculdade de Educação, Universidade de São Paulo, São Paulo, 1994.

STRECK, D. R. “A educação popular e a (re)construção do público. Há fogo sob as brasas?” Revista Brasileira de Educação. Vol.11, $\mathrm{n}^{0} .32$, maio/ago. 2006. Disponível em: <http://www.scielo.br/pdf/rbedu/v11n32/a06v11n32.pdf >. Acesso em: 21 de janeiro de 2008.

TARTUCE, G. L. B. P. "Algumas reflexões sobre a qualificação do trabalho a partir da sociologia francesa do pós-guerra”. Educação e sociedade. Vol.25, nº.87. Campinas, mai./ago. 2004.

THIOLLENT, Michel J. M. Crítica Metodológica, investigação social \& enquete operária. São Paulo: Polis, 1987.

WEINSTEIN, B. (Re) formação da classe trabalhadora no Brasil (1920 - 1964). São Paulo: Cortez/ CADPH-Ifan - Universidade de São Francisco, 2000. 


\section{ANEXOS}

\section{ANEXO 1 - SISTEMATIZAÇÃO DOS QUESTIONÁRIOS APLICADOS NOS ALUNOS}

Projeto de pesquisa: Políticas Públicas de Educação de Jovens e Adultos: a experiência de Santo André com o Programa Integrado de Qualificação

\section{TABULAÇÃO DO QUESTIONÁRIO APLICADO NOS ALUNOS}

Novembro e Dezembro de 2006

Foram pesquisadas duas turmas de cada um dos Centros Públicos de Formação Profissional listados abaixo, sendo uma turma de ensino fundamental e uma turma de ensino médio.

\section{CPFP Armando Mazzo}

Área: construção civil

Ensino Fundamental com Informática

Ensino Médio com Eletricidade com Aperfeiçoamento em Comandos Elétricos

\begin{tabular}{|l|c|c|c|}
\hline \multicolumn{1}{|c|}{ SEXO } & FUNDAMENTAL & MÉDIO & TOTAL \\
\hline HOMENS & 05 & 16 & 21 \\
\hline MULHERES & 02 & 00 & 02 \\
\hline TOTAL & 07 & 16 & 23 \\
\hline
\end{tabular}

\section{CPFP Júlio de Grammont}

Área: comércio e serviços (estética, nutrição, corte e costura)

Ensino Fundamental com Informática

Ensino Médio com Estética

\begin{tabular}{|l|c|c|c|}
\hline \multicolumn{1}{|c|}{ SEXO } & FUNDAMENTAL & MÉDIO & TOTAL \\
\hline HOMENS & 08 & 00 & 08 \\
\hline MULHERES & 21 & 09 & 30 \\
\hline TOTAL & 29 & 09 & 38 \\
\hline
\end{tabular}

\section{CPFP Valdemar Mattei}

Área: informática

Ensino Fundamental com Informática

Ensino Médio com Técnicas Avançadas em Micro Informática

\begin{tabular}{|l|c|c|c|}
\hline \multicolumn{1}{|c|}{ SEXO } & FUNDAMENTAL & MÉDIO & TOTAL \\
\hline HOMENS & 05 & 04 & 09 \\
\hline MULHERES & 05 & 04 & 09 \\
\hline TOTAL & 10 & 08 & 18 \\
\hline
\end{tabular}


Total de alunos pesquisados: 79

\begin{tabular}{|l|c|c|c|}
\hline \multicolumn{1}{|c|}{ SEXO } & FUNDAMENTAL & MÉDIO & TOTAL \\
\hline HOMENS & 18 & 20 & 38 \\
\hline MULHERES & 28 & 13 & 41 \\
\hline TOTAL & 46 & 33 & 79 \\
\hline
\end{tabular}

1. Divisão da faixa etária

Por modalidade

\begin{tabular}{|l|c|c|c|c|c|c|}
\hline MODALIDADE & $\begin{array}{c}\text { Menos } \\
\text { de 18 }\end{array}$ & $\mathbf{1 8}$ a 26 & $\mathbf{2 7}$ a 35 & $\mathbf{3 6}$ a 44 & $\mathbf{4 5}$ a 53 & $\mathbf{5 4}$ a 62 \\
\hline fundamental & 01 & 11 & 14 & 11 & 07 & 02 \\
\hline médio & - & 03 & 05 & 08 & 14 & 03 \\
\hline total & 01 & 14 & 19 & 19 & 21 & 05 \\
\hline
\end{tabular}

Por Centro Público

\begin{tabular}{|l|c|c|c|c|c|c|}
\hline \multicolumn{1}{|c|}{ CENTRO } & $\begin{array}{c}\text { Menos } \\
\text { de 18 }\end{array}$ & $\mathbf{1 8}$ a 26 & $\mathbf{2 7}$ a 35 & $\mathbf{3 6}$ a 44 & $\mathbf{4 5}$ a 53 & $\mathbf{5 4}$ a 62 \\
\hline Armando Mazzo & - & 02 & 05 & 06 & 10 & - \\
\hline $\begin{array}{l}\text { Julio de } \\
\text { Grammont }\end{array}$ & - & 12 & 12 & 04 & 03 & 02 \\
\hline Valdemar Mattei & 01 & - & 02 & 01 & 08 & 03 \\
\hline
\end{tabular}

Por sexo

\begin{tabular}{|l|c|c|c|c|c|c|}
\hline \multicolumn{1}{|c|}{ SEXO } & $\begin{array}{c}\text { Menos } \\
\text { de 18 }\end{array}$ & $\mathbf{1 8}$ a 26 & $\mathbf{2 7}$ a 35 & $\mathbf{3 6}$ a 44 & $\mathbf{4 5}$ a 53 & $\mathbf{5 4}$ a 62 \\
\hline Feminino & 01 & 10 & 12 & 09 & 06 & 03 \\
\hline Masculino & - & 04 & 07 & 10 & 15 & 02 \\
\hline
\end{tabular}

Por cor

\begin{tabular}{|l|c|c|c|c|c|c|c|}
\hline \multicolumn{1}{|c|}{ COR } & $\begin{array}{c}\text { Menos } \\
\text { de 18 }\end{array}$ & $\begin{array}{c}\mathbf{1 8} \text { a } \\
\mathbf{2 6}\end{array}$ & $\begin{array}{c}\mathbf{2 7} \text { a } \\
\mathbf{3 5}\end{array}$ & $\begin{array}{c}\mathbf{3 6} \mathbf{4} \\
\mathbf{4 4}\end{array}$ & $\begin{array}{c}\mathbf{4 5} \text { a } \\
\mathbf{5 3}\end{array}$ & $\begin{array}{c}\mathbf{5 4} \text { a } \\
\mathbf{6 2}\end{array}$ & total \\
\hline branca & - & 07 & 08 & 11 & 15 & 03 & 44 \\
\hline parda & 01 & 06 & 10 & 08 & 06 & 01 & 32 \\
\hline preta & - & - & 01 & - & - & 01 & 02 \\
\hline amarela & - & - & - & - & - & - & 00 \\
\hline não declarada & - & 01 & - & - & - & - & 01 \\
\hline
\end{tabular}


2. Idade com que começou a trabalhar

Por modalidade

\begin{tabular}{|c|c|c|c|c|c|c|c|c|c|c|c|c|}
\hline MODALIDADE & $\begin{array}{c}\text { Menos } \\
\text { de } 7\end{array}$ & $\begin{array}{l}\text { 07 } \\
\text { ou } \\
\text { 08 }\end{array}$ & $\begin{array}{l}\text { 09 } \\
\text { ou } \\
10\end{array}$ & $\begin{array}{l}11 \\
\text { ou } \\
12\end{array}$ & $\begin{array}{l}13 \\
\text { ou } \\
14\end{array}$ & $\begin{array}{l}15 \\
\text { ou } \\
16\end{array}$ & $\begin{array}{l}17 \\
\text { ou } \\
18\end{array}$ & $\begin{array}{l}19 \\
\text { ou } \\
20\end{array}$ & $\begin{array}{c}21 \\
\text { ou } \\
\text { mais }\end{array}$ & $\begin{array}{c}\text { Não } \\
\text { lembra }\end{array}$ & $\begin{array}{l}\text { Nunca } \\
\text { trabalhou }\end{array}$ & $\begin{array}{c}\text { Não } \\
\text { declarou }\end{array}$ \\
\hline Fundamental & - & 04 & 03 & 06 & 11 & 10 & 04 & - & 04 & 01 & 02 & 01 \\
\hline Médio & 01 & 04 & 03 & 06 & 14 & 05 & - & - & - & - & - & - \\
\hline Total & 01 & 08 & 06 & 12 & 25 & 16 & 04 & - & 04 & 01 & 02 & 01 \\
\hline
\end{tabular}

Por Centro Público

\begin{tabular}{|l|c|c|c|c|c|c|c|c|c|c|c|c|}
\hline CENTRO & $\begin{array}{c}\text { Menos } \\
\text { de 7 }\end{array}$ & $\begin{array}{c}\mathbf{0 7} \\
\mathbf{0 u} \\
\mathbf{0 8}\end{array}$ & $\begin{array}{c}\mathbf{0 9} \\
\mathbf{0 u} \\
\mathbf{1 0}\end{array}$ & $\begin{array}{c}\mathbf{1 1} \\
\mathbf{0 u} \\
\mathbf{1 2}\end{array}$ & $\begin{array}{c}\mathbf{1 3} \\
\mathbf{0 u} \\
\mathbf{1 4}\end{array}$ & $\begin{array}{c}\mathbf{1 5} \\
\mathbf{0 u} \\
\mathbf{1 6}\end{array}$ & $\begin{array}{c}\mathbf{1 7} \\
\text { ou } \\
\mathbf{1 8}\end{array}$ & $\begin{array}{c}\mathbf{1 9} \\
\mathbf{0 u} \\
\mathbf{2 0}\end{array}$ & $\begin{array}{c}\mathbf{2 1} \\
\text { ou } \\
\text { mais }\end{array}$ & $\begin{array}{c}\text { Não } \\
\text { lembra }\end{array}$ & $\begin{array}{c}\text { Nunca } \\
\text { trabalhou }\end{array}$ & $\begin{array}{c}\text { Não } \\
\text { declarou }\end{array}$ \\
\hline $\begin{array}{l}\text { Armando } \\
\text { Mazzo }\end{array}$ & - & 03 & 02 & 04 & 08 & 05 & - & - & 01 & - & - & - \\
\hline $\begin{array}{l}\text { Julio de } \\
\text { Grammont }\end{array}$ & 01 & - & 03 & 07 & 11 & 08 & 03 & - & 02 & - & 02 & 01 \\
\hline $\begin{array}{l}\text { Valdemar } \\
\text { Mattei }\end{array}$ & - & 05 & 01 & 01 & 06 & 02 & 01 & - & 01 & 01 & - & - \\
\hline
\end{tabular}

Por sexo

\begin{tabular}{|l|c|c|c|c|c|c|c|c|c|c|c|c|}
\hline \multicolumn{1}{|c|}{ SEXO } & $\begin{array}{c}\text { Menos } \\
\text { de 7 }\end{array}$ & $\begin{array}{c}\mathbf{0 7} \\
\text { ou } \\
\mathbf{0 8}\end{array}$ & $\begin{array}{c}\mathbf{0 9} \\
\text { ou } \\
\mathbf{1 0}\end{array}$ & $\begin{array}{c}\mathbf{1 1} \\
\text { ou } \\
\mathbf{1 2}\end{array}$ & $\begin{array}{c}\mathbf{1 3} \\
\text { ou } \\
\mathbf{1 4}\end{array}$ & $\begin{array}{c}\mathbf{1 5} \\
\text { ou } \\
\mathbf{1 6}\end{array}$ & $\begin{array}{c}\mathbf{1 7} \\
\text { ou } \\
\mathbf{1 8}\end{array}$ & $\begin{array}{c}\mathbf{1 9} \\
\text { ou } \\
\mathbf{2 0}\end{array}$ & $\begin{array}{c}\mathbf{2 1} \\
\text { ou } \\
\text { mais }\end{array}$ & $\begin{array}{c}\text { Não } \\
\text { lembra }\end{array}$ & $\begin{array}{c}\text { Nunca } \\
\text { trabalhou }\end{array}$ & $\begin{array}{c}\text { Não } \\
\text { declarou }\end{array}$ \\
\hline Feminino & 01 & 01 & 04 & 04 & 11 & 10 & 03 & - & 04 & - & 02 & 01 \\
\hline Masculino & - & 06 & 02 & 08 & 14 & 05 & 01 & 01 & - & 01 & - & - \\
\hline
\end{tabular}

Por cor

\begin{tabular}{|l|c|c|c|c|c|c|c|c|c|c|c|c|}
\hline \multicolumn{1}{|c|}{ COR } & $\begin{array}{c}\text { Meno } \\
\text { s de 7 }\end{array}$ & $\begin{array}{c}\mathbf{0 7} \\
\mathbf{0 u} \\
\mathbf{0 8}\end{array}$ & $\begin{array}{c}\mathbf{0 9} \\
\mathbf{0 u} \\
\mathbf{1 0}\end{array}$ & $\begin{array}{c}\mathbf{1 1} \\
\text { ou } \\
\mathbf{1 2}\end{array}$ & $\begin{array}{c}\mathbf{1 3} \\
\text { ou } \\
\mathbf{1 4}\end{array}$ & $\begin{array}{c}\mathbf{1 5} \\
\mathbf{0 u} \\
\mathbf{1 6}\end{array}$ & $\begin{array}{c}\mathbf{1 7} \\
\mathbf{0 u} \\
\mathbf{1 8}\end{array}$ & $\begin{array}{c}\mathbf{1 9} \\
\mathbf{0 u} \\
\mathbf{2 0}\end{array}$ & $\begin{array}{c}\mathbf{2 1} \text { ou } \\
\text { mais }\end{array}$ & $\begin{array}{c}\text { Não } \\
\text { lembra }\end{array}$ & $\begin{array}{c}\text { Nunca } \\
\text { trabalho } \\
\text { u }\end{array}$ & $\begin{array}{c}\text { Não } \\
\text { declarou }\end{array}$ \\
\hline branca & - & 05 & 03 & 06 & 19 & 08 & - & - & 01 & 01 & - & - \\
\hline parda & 01 & 02 & 03 & 04 & 06 & 06 & 04 & 01 & 03 & - & 02 & 01 \\
\hline preta & - & - & - & 02 & - & - & - & - & - & - & - & - \\
\hline amarela & - & - & - & - & - & - & - & - & - & - & - & - \\
\hline $\begin{array}{l}\text { não } \\
\text { declarada }\end{array}$ & - & - & - & - & - & 01 & - & - & - & - & - & - \\
\hline
\end{tabular}


3. Região onde começou a trabalhar por sexo

\begin{tabular}{|l|c|c|c|}
\hline \multicolumn{1}{|c|}{ REGIÃo } & HOMENS & MULHERES & TOTAL \\
\hline Norte & - & - & - \\
\hline Nordeste & 04 & 06 & 10 \\
\hline Centro Oeste & - & -- & \\
\hline Sudeste (exceto São Paulo) & 02 & 01 & 03 \\
\hline Sul & 03 & 01 & 04 \\
\hline $\begin{array}{l}\text { Grande São Paulo (exceto } \\
\text { Santo André) }\end{array}$ & 01 & 06 & 07 \\
\hline Interior de São Paulo & 01 & 01 & 02 \\
\hline ABC (exceto Santo André) & 04 & 01 & 05 \\
\hline Santo André & 21 & 23 & 44 \\
\hline Não respondeu & 01 & 03 & 04 \\
\hline
\end{tabular}

4. Atividade do primeiro trabalho por sexo e idade

HOMENS

\begin{tabular}{|l|c|c|c|c|c|c|c|c|c|}
\hline \multicolumn{1}{|c|}{ ATIVIDADE } & $\begin{array}{c}\text { Menos } \\
\text { de } 07\end{array}$ & $\begin{array}{c}\mathbf{0 7} \text { ou } \\
\mathbf{0 8}\end{array}$ & $\begin{array}{c}\mathbf{0 9} \text { ou } \\
\mathbf{1 0}\end{array}$ & $\begin{array}{c}\mathbf{1 1} \text { ou } \\
\mathbf{1 2}\end{array}$ & $\begin{array}{c}\mathbf{1 3} \text { ou } \\
\mathbf{1 4}\end{array}$ & $\begin{array}{c}\mathbf{1 5} \text { ou } \\
\mathbf{1 6}\end{array}$ & $\begin{array}{c}\mathbf{1 7} \text { ou } \\
\mathbf{1 8}\end{array}$ & $\begin{array}{c}\mathbf{1 9} \text { ou } \\
\mathbf{2 0}\end{array}$ & $\begin{array}{c}\mathbf{2 1} \\
\text { ou } \\
\text { mais }\end{array}$ \\
\hline Ajudante geral & - & - & - & 01 & - & - & 01 & 01 & - \\
\hline $\begin{array}{l}\text { Ajudante de } \\
\text { oficina }\end{array}$ & - & 01 & - & - & - & - & - & - & 01 \\
\hline $\begin{array}{l}\text { Ajudante de } \\
\text { padeiro }\end{array}$ & - & - & - & - & - & - & - & - \\
\hline $\begin{array}{l}\text { Ajudante de } \\
\text { tapeceiro }\end{array}$ & - & - & - & - & 01 & - & - & - & - \\
\hline $\begin{array}{l}\text { Ajudante de } \\
\text { marceneiro }\end{array}$ & - & - & - & - & - & 01 & - & - & - \\
\hline $\begin{array}{l}\text { Ajudante de } \\
\text { produção }\end{array}$ & - & 01 & - & - & - & - & - & - & - \\
\hline $\begin{array}{l}\text { Auxiliar de } \\
\text { escritório }\end{array}$ & - & - & - & - & 01 & - & - & - & - \\
\hline $\begin{array}{l}\text { Aprendiz de } \\
\text { ajustador }\end{array}$ & - & - & - & - & 01 & - & - & - & - \\
\hline $\begin{array}{l}\text { Aprendiz de } \\
\text { torneiro } \\
\text { mecânico }\end{array}$ & - & - & - & - & - & - & - & - & - \\
\hline $\begin{array}{l}\text { Atendente de } \\
\text { feira }\end{array}$ & - & - & - & 01 & - & - & - & - & - \\
\hline $\begin{array}{l}\text { Entregador de } \\
\text { leite }\end{array}$ & - & - & - & 01 & - & - & - & - & - \\
\hline Vendedor & - & 01 & - & 02 & 01 & - & - & - & - \\
\hline
\end{tabular}




\begin{tabular}{|l|c|c|c|c|c|c|c|c|c|}
\hline $\begin{array}{l}\text { Moldador em } \\
\text { cerâmica }\end{array}$ & - & - & - & - & 01 & - & - & - & - \\
\hline $\begin{array}{l}\text { Montador de } \\
\text { cadeira }\end{array}$ & - & - & - & - & - & - & - & - & - \\
\hline $\begin{array}{l}\text { Balconista de } \\
\text { lanchonete }\end{array}$ & - & - & - & - & 01 & & - & - & - \\
\hline Balconista & - & - & - & - & 02 & - & - & - & - \\
\hline Pintor & - & - & - & - & - & 01 & - & - & - \\
\hline Sapateiro & - & - & - & - & - & 01 & - & - & \\
\hline Catador de lixo & - & 01 & - & - & - & - & - & - & - \\
\hline Lavrador & - & 03 & 02 & - & - & 01 & - & - & - \\
\hline $\begin{array}{l}\text { Vigilante no } \\
\text { campo }\end{array}$ & - & - & - & - & 01 & - & - & - & - \\
\hline Office-boy & - & - & - & - & 03 & 01 & - & - & - \\
\hline Estoquista & - & - & - & 01 & - & - & - & - & - \\
\hline Não lembra - 01 & - & - & - & - & - & - & - & - & - \\
\hline $\begin{array}{l}\text { Ajudante geral }- \\
\text { não especificou } \\
\text { idade 01 }\end{array}$ & & & & & & & & & \\
\hline Total & 00 & 07 & 02 & 06 & 13 & 05 & 01 & 01 & 01 \\
\hline
\end{tabular}

\section{MULHERES}

\begin{tabular}{|c|c|c|c|c|c|c|c|c|c|}
\hline ATIVIDADE & $\begin{array}{c}\text { Menos } \\
\text { de } 07\end{array}$ & $\begin{array}{c}07 \text { ou } \\
08\end{array}$ & $\begin{array}{c}09 \text { ou } \\
10\end{array}$ & $\begin{array}{c}11 \text { ou } \\
12\end{array}$ & $\begin{array}{c}13 \text { ou } \\
14\end{array}$ & $\begin{array}{l}15 \text { ou } \\
16\end{array}$ & $\begin{array}{c}17 \text { ou } \\
18\end{array}$ & $\begin{array}{c}19 \text { ou } \\
20\end{array}$ & $\begin{array}{c}21 \\
\text { ou } \\
\text { mais }\end{array}$ \\
\hline $\begin{array}{l}\text { Empregada } \\
\text { doméstica }\end{array}$ & - & - & 02 & 01 & 01 & - & - & & - \\
\hline $\begin{array}{l}\text { Empregada } \\
\text { diarista }\end{array}$ & - & - & - & - & - & - & 01 & - & - \\
\hline $\begin{array}{l}\text { Auxiliar de } \\
\text { limpeza }\end{array}$ & - & - & - & - & - & - & - & - & 02 \\
\hline Babá & - & - & 01 & 02 & 01 & 02 & - & - & - \\
\hline Costureira & - & - & - & - & 02 & & 01 & - & - \\
\hline Embaladora & - & - & - & - & - & 01 & - & - & - \\
\hline Vendedora & - & - & - & - & - & 01 & - & - & - \\
\hline $\begin{array}{l}\text { Atendente de } \\
\text { restaurante }\end{array}$ & - & - & - & - & - & 02 & - & - & - \\
\hline $\begin{array}{l}\text { Atendente de } \\
\text { feira }\end{array}$ & 01 & - & - & - & 01 & - & - & - & - \\
\hline $\begin{array}{l}\text { Atendente de } \\
\text { padaria }\end{array}$ & - & - & - & - & - & - & 01 & - & - \\
\hline $\begin{array}{l}\text { Atendente de } \\
\text { telefone }\end{array}$ & - & - & - & - & - & 01 & - & - & - \\
\hline Ajudante de & - & - & - & - & 01 & - & - & - & - \\
\hline
\end{tabular}




\begin{tabular}{|l|c|c|c|c|c|c|c|c|c|}
\hline $\begin{array}{l}\text { montagem } \\
\text { persianas }\end{array}$ & & & & & & & & & \\
\hline $\begin{array}{l}\text { Ajudante de } \\
\text { produção }\end{array}$ & - & - & - & 01 & 01 & - & - & - & 01 \\
\hline Ajudante geral & - & - & - & - & 02 & - & - & - & - \\
\hline Balconista & - & - & - & 01 & 01 & - & - & - & - \\
\hline Lavradora & - & 01 & 01 & - & - & - & - & - & - \\
\hline Panfleteira & - & - & - & - & 01 & - & - & - & - \\
\hline Guarda mirim & - & - & - & - & 02 & 01 & - & - & - \\
\hline $\begin{array}{l}\text { Pesquisadora de } \\
\text { campo } \\
\text { (Programa 1 } \\
\text { Emrpego) }\end{array}$ & - & - & - & - & - & - & - & - & 01 \\
\hline $\begin{array}{l}\text { Nunca trabalhou } \\
- \text { 02 }\end{array}$ & - & - & - & - & - & - & - & - & - \\
\hline Total & 01 & 01 & 04 & 05 & 13 & 08 & 03 & 00 & 04 \\
\hline
\end{tabular}

Obs.: alguns alunos não responderam essa questão

5. Número de horas de trabalho por dia por sexo no primeiro emprego

\begin{tabular}{|l|c|c|c|c|c|c|c|c|c|}
\hline \multicolumn{1}{|c|}{ HORAS } & $\begin{array}{c}\text { Menos } \\
\text { de 04 }\end{array}$ & $\begin{array}{c}\mathbf{0 4} \text { a } \\
\mathbf{0 6}\end{array}$ & $\mathbf{0 7}$ & $\mathbf{0 8}$ & $\mathbf{0 9}$ & $\mathbf{1 0}$ & $\begin{array}{c}\text { Mais } \\
\text { de 10 }\end{array}$ & $\begin{array}{c}\text { Horas } \\
\text { indeterminadas }\end{array}$ & $\begin{array}{c}\text { Nunca } \\
\text { trabalhou }\end{array}$ \\
\hline homens & - & 09 & 01 & 09 & 07 & 04 & 02 & 05 & - \\
\hline mulheres & - & 11 & 01 & 11 & 07 & 05 & 04 & 01 & 02 \\
\hline
\end{tabular}

6. Trabalhos já realizados que resultaram em satisfação pessoal por Centro e por sexo Armando Mazzo

\begin{tabular}{|l|l|}
\hline \multicolumn{1}{|c|}{ HOMENS } & \multicolumn{1}{c|}{ MULHERES } \\
\hline Mecânico de manutenção & Empregada doméstica \\
\hline Serralheiro & Empresa metalúrgica (não especificou o cargo) \\
\hline Encarregado de montagem & \\
\hline Encarregado de manutenção & \\
\hline Supervisor de montagem e tubulação industrial & \\
\hline Técnico de montagem & \\
\hline Tapeceiro & \\
\hline Pintor residencial & \\
\hline Linha de montagem de carro & \\
\hline Office-boy & \\
\hline Vendedor & \\
\hline Comprador & \\
\hline
\end{tabular}




\begin{tabular}{|l|l|}
\hline Editor de vídeo & \\
\hline Balconista & \\
\hline Encarregado de seção & \\
\hline Auxiliar de produção & \\
\hline Operador de máquinas & \\
\hline Instalador de antenas & \\
\hline Nenhum dos trabalhos & \\
\hline Eletricista & \\
\hline Lavrador & \\
\hline Torneiro mecânico & \\
\hline Ajustador mecânico & \\
\hline Impressor gráfico & \\
\hline Ajudante de tecelagem & \\
\hline Auxiliar administrativo em multinacional & \\
\hline Marcenaria & \\
\hline Colocador de pisos laminados & \\
\hline Técnico de iluminação & \\
\hline Engraxate & \\
\hline Balconista de padaria & \\
\hline Caixa de padaria & \\
\hline Vigilante & \\
\hline Líder de segurança & \\
\hline Técnico em eletrodomésticos & \\
\hline Pintor de automóveis & \\
\hline Vendedor autônomo & \\
\hline Segurança em casa de baile & \\
\hline
\end{tabular}

Valdemar Mattei

\begin{tabular}{|c|c|}
\hline HOMENS & MULHERES \\
\hline Tecelão & Vendedora \\
\hline Sapateiro & Copeira \\
\hline Motorista & Encarregada de limpeza \\
\hline Músico profissional & Serviços artesanais \\
\hline Almoxarife & Cozinheira \\
\hline Marcenaria & Balconista \\
\hline Ferramenteiro & Recepcionista \\
\hline Encanador & Secretária \\
\hline Fresador de peças & Ajudante de produção \\
\hline Balconista & Demonstradora de vendas \\
\hline Ajudante de relojoeiro & Corretora de seguros \\
\hline
\end{tabular}




\begin{tabular}{|l|l|}
\hline Ajustador & Empregada doméstica \\
\hline Plainador & Ajudante em hospital \\
\hline Operador de mesa limadora & Costureira \\
\hline Frezador & Bordadeira \\
\hline Mandrilhador & Operadora de máquina \\
\hline Eletricista & Revendedora de cosméticos \\
\hline Pintor de automóveis & Comerciante \\
\hline Montador de cadeiras & Atendente de telefone \\
\hline
\end{tabular}

Júlio de Grammont

\begin{tabular}{|c|c|}
\hline HOMENS & MULHERES \\
\hline Ajudante de pedreiro & Atendente de enfermagem \\
\hline Auxiliar de limpeza & Guia de turismo \\
\hline Balconista & Montadora de peças de telefone \\
\hline Motorista & Ajudante de cabeleireiro \\
\hline Encarregado e supervisor de mecânica & Ajudante de produção de vasos de porcelana \\
\hline Promotor de vendas & Ajudante de produção em fábrica de lingerie \\
\hline Operador de máquina & Auxiliar de cabeleireiro \\
\hline Vidraceiro & Auxiliar de farmácia \\
\hline Gesseiro & Agente administrativo \\
\hline Quadrista & Cabeleireira \\
\hline Todos & Manicure \\
\hline Ajudante de encanador & Vendedora \\
\hline \multirow[t]{17}{*}{ Técnico em consertos hidráulicos } & Massagista \\
\hline & Recepcionista \\
\hline & Feirante \\
\hline & Balconista \\
\hline & Crocheteira \\
\hline & Pesquisadora \\
\hline & Atendente de restaurante Mc Donald's \\
\hline & Ajudante de cozinha \\
\hline & Empregada doméstica \\
\hline & Babá \\
\hline & Manicure \\
\hline & Auxiliar de escritório \\
\hline & Costureira \\
\hline & Bordadeira \\
\hline & Artesã \\
\hline & Atendente na Vale do Rio Doce \\
\hline & Ajudante de produção \\
\hline
\end{tabular}




\begin{tabular}{|l|l|}
\hline & Operadora de máquina \\
\hline & Auxiliar de limpeza no elevador \\
\hline & Auxiliar de limpeza em escola \\
\hline & Berçarista \\
\hline
\end{tabular}

7. Motivos da satisfação

\begin{tabular}{|l|c|c|}
\hline \multicolumn{1}{|c|}{ MOTIVOS } & HOMENS & MULHERES \\
\hline Domínio, bom desempenho & 02 & 00 \\
\hline Qualidade do produto reconhecida & 01 & 00 \\
\hline Aprender a operar máquina & 01 & 00 \\
\hline Afinidade com a atividade, adaptação & 08 & 10 \\
\hline Sentir-se útil & 02 & 00 \\
\hline Renda & 07 & 05 \\
\hline Fazer e ver o resultado & 01 & 00 \\
\hline Orgulho do trabalho realizado & 02 & 02 \\
\hline Não falta serviço e a renda é boa & 01 & 00 \\
\hline Aprendeu uma profissão & 01 & 00 \\
\hline Trabalhar com o público & 03 & 06 \\
\hline Descoberta de novas habilidades, experiências & 03 & 06 \\
\hline Reconhecimento & 02 & 02 \\
\hline Novos amigos & 01 & 02 \\
\hline Facilidade em arrumar trabalho & 01 & 00 \\
\hline Atender pessoas educadas & 00 & 01 \\
\hline Conhecer todas as tarefas do trabalho & 00 & 01 \\
\hline Conhecer pessoas & 00 & 02 \\
\hline Transformação pessoal & 00 & 02 \\
\hline Sempre trabalhou nisso e não mudou & 00 & 01 \\
\hline Trabalho digno & 00 & 01 \\
\hline Registro na carteira & 00 & 02 \\
\hline É um serviço mais tranqüilo, menos pesado & 00 & 02 \\
\hline $\begin{array}{l}\text { O que aprendeu no trabalho não esqueceu } \\
\text { nunca }\end{array}$ & 00 & \\
\hline & & \\
\hline
\end{tabular}

8. Trabalhos já realizados que resultaram em insatisfação pessoal por Centro e por sexo

Armando Mazzo

\begin{tabular}{|l|l|}
\hline \multicolumn{1}{|c|}{ HOMENS } & \multicolumn{1}{c|}{ MULHERES } \\
\hline Linha de montagem & Empregada doméstica \\
\hline
\end{tabular}




\begin{tabular}{|l|l|}
\hline Vendedor & Arrumadeira \\
\hline Office-boy & \\
\hline Balconista & \\
\hline Pipoqueiro & \\
\hline Sorveteiro & \\
\hline Empacotador & \\
\hline Servente de pedreiro & \\
\hline Aplicador de herbicida & \\
\hline Cortar cana & \\
\hline Faxineiro & \\
\hline Atendente de lanchonete & \\
\hline Vendedor & \\
\hline Entregador de mercadoria & \\
\hline Ajudante de motorista & \\
\hline Ajudante de produção metalúrgica & \\
\hline Serviços temporários & \\
\hline Lavador de carros & \\
\hline Vigilante & \\
\hline Cobrador & \\
\hline Nenhum & \\
\hline Ajudante de pedreiro & \\
\hline Ajudante geral & \\
\hline Encarregado de modelação & \\
\hline Quebrar poste de concreto & \\
\hline Nenhum & \\
\hline
\end{tabular}

Júlio de Grammont

\begin{tabular}{|c|c|}
\hline $\begin{array}{r}\text { HOMENS } \\
\end{array}$ & MULHERES \\
\hline Servente de pedreiro & Panfleteira \\
\hline Office-boy & Empregada doméstica \\
\hline Mecânico de fundição & Ajudante de produção \\
\hline Porteiro & Cuidar de casa \\
\hline Ajudante geral & Ajudante de cozinha \\
\hline Ajudante de encanador & Babá \\
\hline \multirow[t]{6}{*}{ Ajudante de depósito de sucata } & Cuidadora de idosos \\
\hline & Garçonete \\
\hline & Auxiliar de limpeza \\
\hline & Lavradora \\
\hline & Auxiliar de empacotamento \\
\hline & Vendedora \\
\hline
\end{tabular}




\begin{tabular}{|l|l|}
\hline & Ajudante de prensa \\
\hline & Auxiliar de cabeleireiro \\
\hline & Secretária de advocacia \\
\hline & Operadora de caixa \\
\hline & Revelação de filmes \\
\hline
\end{tabular}

Valdemar Mattei

\begin{tabular}{|l|l|}
\hline \multicolumn{1}{|c|}{ HOMENS } & \multicolumn{1}{c|}{ MULHERES } \\
\hline Catador de lixo reciclável & Lavradora \\
\hline Ajudante de pedreiro & Empregada doméstica \\
\hline Lavrador & Ajudante geral \\
\hline Ajudante geral & Panfleteira \\
\hline Motorista & Empregada diarista \\
\hline Montar lustres & \\
\hline
\end{tabular}

9. Motivos da insatisfação por sexo

\begin{tabular}{|l|c|c|}
\hline \multicolumn{1}{|c|}{ MOTIVOS } & HOMENS & MULHERES \\
\hline Atividade sem perspectiva de melhora & 05 & 01 \\
\hline Mudança de cidade, local novo & 01 & - \\
\hline Trabalho cansativo, desgastante & 04 & 08 \\
\hline Trabalho humilhante & 02 & 03 \\
\hline Muita exigência e pouca remuneração & 01 & - \\
\hline Pouca remuneração & 02 & 03 \\
\hline Trabalho não valorizado, sem reconhecimento & 02 & 02 \\
\hline Trabalho não permitia continuar os estudos & 01 & - \\
\hline Trabalho muito solitário & 01 & 03 \\
\hline Trabalho insalubre ou perigoso & 03 & 02 \\
\hline Exploração indevida do trabalho & 01 & 05 \\
\hline Falta de afinidade & 04 & 02 \\
\hline Começou a trabalhar muito cedo & - & 01 \\
\hline $\begin{array}{l}\text { Diferença de salário para mesma atividade } \\
\text { entre homens e mulheres }\end{array}$ & - & 02 \\
\hline Ausência de direitos ou benefícios & 03 & - \\
\hline Ausência de qualificação para a função & 01 & - \\
\hline Indisposição com colegas devido a função & 01 & - \\
\hline $\begin{array}{l}\text { Dificuldade em conciliar horário de trabalho e } \\
\text { de estudo }\end{array}$ & 01 & - \\
\hline Muita exigência, estressante & 01 & \\
\hline Trabalho que não exige nenhum esforço & 01 & \\
\hline
\end{tabular}




\begin{tabular}{|l|c|c|}
\hline mental & & \\
\hline Não era uma profissão & 01 & - \\
\hline $\begin{array}{l}\text { Não foi dada oportunidade de crescimento na } \\
\text { área }\end{array}$ & 01 & - \\
\hline Trabalho instável, oscilante & 01 & - \\
\hline Função exigia indispor-se com as pessoas & 01 & - \\
\hline
\end{tabular}

10. Quais trabalhos tornaram-se profissão por sexo

\begin{tabular}{|c|c|}
\hline HOMENS & MULHERES \\
\hline Encarregado de seção de rede de mercado & Empregada doméstica \\
\hline Operador de máquinas de enlatamento & Nenhum 9 \\
\hline Editor de vídeo & Empregada doméstica e cuidadora de animais \\
\hline Todos 2 & Auxiliar de limpeza 2 \\
\hline Nenhum 2 & Balconista \\
\hline Eletricista residencial 5 & Manicure 2 \\
\hline Torneiro mecânico & Auxiliar de escritório \\
\hline Operador de máquina industrial & Dama de companhia em enfermagem \\
\hline Porteiro de condomínio & Operadora de máquina 2 \\
\hline Impressor gráfico & Babá \\
\hline Arquivista & Costureira 2 \\
\hline Marceneiro 2 & Cuidar de crianças em escola \\
\hline Pintor 2 & Auxiliar de limpeza em escola \\
\hline Técnico de iluminação & Recepcionista 3 \\
\hline Guarda & Cabeleireira 2 \\
\hline Caixa contábil & Guia de turismo \\
\hline Técnico em eletro doméstico & Ajudante em fábrica de lingerie \\
\hline Encarregado e supervisor & Agente administrativo \\
\hline Ajudante de oficina & Encarregada de limpeza \\
\hline Autônomo & Massagista \\
\hline Metalúrgica (não especificou função) & Atendente de perfumaria \\
\hline Alimentação (não especifiou) & Revelação de filmes \\
\hline Segurança & Atendente de feira \\
\hline Eletricista de automóvel & Pesquisadora de campo \\
\hline Ajustador & Vendedora \\
\hline Ajudante geral & Cozinheira 2 \\
\hline Promotor de vendas & Todos 2 \\
\hline Vidraceiro & Bordadeira \\
\hline Assistência técnica em hidráulica & Revendedora de cosméticos \\
\hline Motorista & Comerciante \\
\hline
\end{tabular}




\begin{tabular}{|l|l|}
\hline Almoxarife & \\
\hline Ajudante de pedreiro & \\
\hline Fresador de peças 2 & \\
\hline Balconista & \\
\hline Mandrilhador & \\
\hline Instalador telefônico & \\
\hline Pintor de automóvel & \\
\hline Montador de cadeira & \\
\hline
\end{tabular}

\section{Motivos por sexo}

\begin{tabular}{|c|c|}
\hline HOMENS & MULHERES \\
\hline $\begin{array}{l}\text { A função oportunizou ampliação de } \\
\text { conhecimentos e experiências } 7\end{array}$ & Registro em carteira \\
\hline Há muito campo de trabalho 2 & $\begin{array}{l}\text { A função oportunizou ampliação de } \\
\text { conhecimentos e experiências } 7\end{array}$ \\
\hline Aprendeu quando estava desempregado & $\begin{array}{l}\text { Foi a atividade que desempenhou por mais } \\
\text { tempo }\end{array}$ \\
\hline Renda razoável, bom salário 4 & Domínio da função 2 \\
\hline Tem muito emprego e trabalha pouco & Conseguiu emprego \\
\hline $\begin{array}{l}\text { Foi a atividade que desempenhou por mais } \\
\text { tempo } 4\end{array}$ & Melhor adaptação, afinidade, prazer 6 \\
\hline Melhor adaptação, afinidade, prazer 4 & Perspectiva de estudo \\
\hline Salário compatível com os gastos & Possibilitou promoção \\
\hline Conhecimentos adquiridos permaneceram & A empresa deu formação em serviço \\
\hline Tem mais opções de trabalho & Aprendeu a cuidar melhor dos filhos \\
\hline Possibilitou promoção 2 & Domínio completo da função 3 \\
\hline $\begin{array}{l}\text { Foram oferecidos cursos de qualificação na área } \\
2\end{array}$ & Pode trabalhar autonomamente 3 \\
\hline Domínio completo da função 4 & Reconhecimento do trabalho 2 \\
\hline $\begin{array}{l}\text { Aprender a trabalhar com os processos e as } \\
\text { pessoas }\end{array}$ & Tem mais opções de trabalho \\
\hline Pode sustentar a família 4 & Compartilhar decisões no trabalho \\
\hline $\begin{array}{l}\text { Transferência de conhecimentos para outras } \\
\text { funções }\end{array}$ & Atender ao público 3 \\
\hline Ofereceu perspectiva de vida & Sentia-se uma profissional \\
\hline A função oportunizou vários empregos & Conhecimentos adquiridos permaneceram \\
\hline Atender ao público & $\begin{array}{l}\text { Podia usar os conhecimentos adquiridos na } \\
\text { escola }\end{array}$ \\
\hline
\end{tabular}


12. Conhecimentos pessoas e profissionais que foram adquiridos com o trabalho

\begin{tabular}{|c|c|}
\hline HOMENS & MULHERES \\
\hline Atender ao público 3 & Experiência com as pessoas 5 \\
\hline Honestidade 2 & Atender ao público 4 \\
\hline Domínio técnico da função 11 & Fazer amizades 3 \\
\hline Compromisso com o trabalho & Necessidade de estudar \\
\hline Fazer amizades & Conhecer costumes e lugares diferentes \\
\hline Relacionar-se com as pessoas & Confiança \\
\hline Informática & Honestidade \\
\hline Técnicas de trabalho 2 & Liderança \\
\hline Ser respeitado no trabalho 2 & Criatividade \\
\hline Responsabilidade & Domínio técnico da função 4 \\
\hline Fazer novas coisas & Lidar com as pessoas 3 \\
\hline Ouvir & Respeitar as pessoas 3 \\
\hline Conviver com a sociedade & Limites \\
\hline Responsabilidade & Auxiliar as pessoas com seu conhecimento \\
\hline Caráter & "engolir sapo" \\
\hline Humildade & Cumprir horários \\
\hline Entendimento & Ter responsabilidade 3 \\
\hline Sabedoria & Pagar as próprias contas \\
\hline Nenhum & Independência \\
\hline Interpretar desenhos & Cuidar bem dos filhos \\
\hline Conhecer medidas & Aprendeu a gostar de criança \\
\hline Entender as orientações & Persistência \\
\hline Rotina de escritório & Tolerância \\
\hline Lidar com pessoas de todos os tipos & Conviver com pessoas diferentes 3 \\
\hline Conviver em grupo & Adquirir consciência de vida \\
\hline \multirow[t]{8}{*}{ Auxiliar as pessoas com seu conhecimento } & Perdeu a timidez, melhorou a comunicação 2 \\
\hline & Trabalhar em grupo \\
\hline & $\begin{array}{l}\text { Consciência da importância de seu trabalho para } \\
\text { os outros }\end{array}$ \\
\hline & Compromisso com o trabalho \\
\hline & Bom comportamento no trabalho \\
\hline & Observação \\
\hline & Separar a amizade do profissional \\
\hline & Diferenciar o que é certo e errado \\
\hline
\end{tabular}

Obs.: alguns alunos não especificaram ou deram respostas não diretamente relacionadas com a questão 
13. Onde foi a alfabetização e idade

\begin{tabular}{|c|c|c|c|c|c|c|c|c|c|c|}
\hline & $\begin{array}{c}\text { Menos } \\
\text { de } 07\end{array}$ & $\begin{array}{c}07 \text { ou } \\
08\end{array}$ & $\begin{array}{c}09 \text { ou } \\
10\end{array}$ & $\begin{array}{c}11 \text { ou } \\
12\end{array}$ & $\begin{array}{c}13 \text { ou } \\
14\end{array}$ & $\begin{array}{c}15 \text { ou } \\
16\end{array}$ & $\begin{array}{c}17 \text { ou } \\
18\end{array}$ & $\begin{array}{c}19 \text { ou } \\
20\end{array}$ & $\begin{array}{l}21 \text { ou } \\
\text { mais }\end{array}$ & $\begin{array}{c}\text { Não } \\
\text { lembra } \\
\mathbf{a} \\
\text { idade }\end{array}$ \\
\hline $\begin{array}{l}\text { Pública na } \\
\text { gde. SP }\end{array}$ & 03 & 26 & 02 & 02 & 02 & - & - & - & 01 & 02 \\
\hline $\begin{array}{l}\text { Pública em } \\
\text { outro estado }\end{array}$ & - & 07 & 02 & 03 & 02 & - & - & - & - & - \\
\hline $\begin{array}{l}\text { Pública no } \\
\text { interior de SP }\end{array}$ & - & 01 & 02 & - & - & - & - & - & - & - \\
\hline Pública rural & 01 & 02 & 01 & - & - & - & - & - & - & - \\
\hline $\begin{array}{l}\text { Particular em } \\
\text { SP }\end{array}$ & 01 & - & - & - & - & - & - & - & - & - \\
\hline MOBRAL & - & - & - & - & - & - & - & - & 01 & - \\
\hline $\begin{array}{l}\text { Colégio } \\
\text { Militar em } \\
\text { outro estado }\end{array}$ & - & - & - & - & - & - & - & - & - & 01 \\
\hline $\begin{array}{l}\text { Com } \\
\text { professora } \\
\text { fora da escola } \\
\text { em outro } \\
\text { estado }\end{array}$ & - & - & - & - & - & - & - & - & - & 01 \\
\hline TOTAL & 05 & 36 & 07 & 05 & 04 & - & - & - & 02 & 04 \\
\hline
\end{tabular}

Obs.: Do total dos questionários, 16 respostas não especificaram a idade ou o local

14. Série cursada antes de vir para o Centro Público

Ensino Fundamental

\begin{tabular}{|l|c|c|c|c|c|c|c|c|}
\hline \multicolumn{1}{|c|}{ SEXO } & $\mathbf{1}^{\mathbf{a}}$ & $\mathbf{2}^{\mathbf{a}}$ & $\mathbf{3}^{\mathbf{a}}$ & $\mathbf{4}^{\mathbf{a}}$ & $\mathbf{5}^{\mathbf{a}}$ & $\mathbf{6}^{\mathbf{a}}$ & $\mathbf{7}^{\mathbf{a}}$ & $\mathbf{8}^{\mathbf{a}}$ \\
\hline feminino & & 01 & 01 & 07 & 04 & 13 & 08 & 03 \\
\hline masculino & & & 01 & 06 & 11 & 07 & 07 & 03 \\
\hline
\end{tabular}

Ensino Médio

\begin{tabular}{|l|l|l|c|}
\hline \multicolumn{1}{|c|}{ SEXO } & $\mathbf{1}^{\mathbf{0}}$ & $\mathbf{2}^{\mathbf{o}}$ & $\mathbf{3}^{\mathbf{o}}$ \\
\hline feminino & 01 & 02 & 01 \\
\hline masculino & 02 & 01 & - \\
\hline
\end{tabular}


15. Número de instituições de ensino pelas quais passou antes do Centro Público

Por nível

\begin{tabular}{|l|c|c|c|c|c|c|}
\hline \multicolumn{1}{|c|}{ NÍVEL } & nenhuma & $\begin{array}{c}\text { Não } \\
\text { respondeu }\end{array}$ & $\mathbf{1}$ & $\mathbf{2}$ & $\mathbf{3}$ & 4 ou mais \\
\hline Fundamental & - & - & 12 & 14 & 09 & 11 \\
\hline Médio & - & 01 & 08 & 10 & 10 & 04 \\
\hline
\end{tabular}

Por sexo

\begin{tabular}{|l|c|c|c|c|c|c|}
\hline \multicolumn{1}{|c|}{ SEXO } & nenhuma & $\begin{array}{c}\text { Não } \\
\text { respondeu }\end{array}$ & $\mathbf{1}$ & $\mathbf{2}$ & $\mathbf{3}$ & $\mathbf{4}$ \\
\hline feminino & - & - & 09 & 14 & 08 & 10 \\
\hline masculino & - & 01 & 11 & 10 & 11 & 05 \\
\hline
\end{tabular}

16. Pessoas que contribuíram na vida escolar, não ligadas a escola, no conjunto

\begin{tabular}{|c|c|c|c|c|c|c|c|}
\hline pais & $\begin{array}{c}\text { Esposa } \\
\text { ou } \\
\text { marido }\end{array}$ & parentes & amigos & vizinhos & outros & ninguém & $\begin{array}{c}\text { Alguém, sem } \\
\text { especificação }\end{array}$ \\
\hline 10 & 02 & 09 & 03 & 01 & 06 & 44 & 01 \\
\hline
\end{tabular}

Obs: Alguns alunos não responderam essa questão e outros apontaram mais de um dos itens acima

17. Motivos pelos quais o processo de escolaridade foi interrompido, por sexo

\begin{tabular}{|l|c|c|}
\hline \multicolumn{1}{|c|}{ MOTIVOS } & HOMENS & MULHERES \\
\hline $\begin{array}{l}\text { Incompatibilidade entre horário } \\
\text { de trabalho e estudo }\end{array}$ & 28 & 14 \\
\hline Cansaço devido ao trabalho & 15 & 17 \\
\hline Cuidar dos filhos & 02 & 15 \\
\hline Cuidar da casa & 02 & 03 \\
\hline Não havia escola próxima & 05 & 02 \\
\hline $\begin{array}{l}\text { Não havia dinheiro para } \\
\text { condução }\end{array}$ & 04 & 05 \\
\hline Saúde & 02 & 04 \\
\hline Os pais não deixaram & 01 & 08 \\
\hline Marido ou esposa não deixaram & - & 03 \\
\hline Escola não era boa & 02 & - \\
\hline Trabalhava por revezamento & 01 & - \\
\hline $\begin{array}{l}\text { Não havia escola com segundo } \\
\text { segmento do ensino } \\
\text { fundamental }\end{array}$ & 01 & \\
\hline
\end{tabular}




\begin{tabular}{|l|c|c|}
\hline $\begin{array}{l}\text { A família nunca se preocupou } \\
\text { em mandar para a escola }\end{array}$ & - & 01 \\
\hline Para casar & 01 & 01 \\
\hline Porque concluiu o primário & 01 & - \\
\hline $\begin{array}{l}\text { Não tinha dinheiro para } \\
\text { comprar material }\end{array}$ & - & 01 \\
\hline migração & - & 03 \\
\hline $\begin{array}{l}\text { Não quis continuar para poder } \\
\text { trabalhar }\end{array}$ & 03 & - \\
\hline Abandonou a escola & 01 & 01 \\
\hline Não conseguiu vaga & - & 02 \\
\hline Falta de interesse & 01 & - \\
\hline $\begin{array}{l}\text { Diretoras eram coniventes com } \\
\text { discriminação sofrida }\end{array}$ & 01 & - \\
\hline $\begin{array}{l}\text { Estudava em escola particular e } \\
\text { teve que abandonar }\end{array}$ & 01 & - \\
\hline Dificuldade financeira & 01 & - \\
\hline Nunca parou de estudar & 01 & 01 \\
\hline
\end{tabular}

18. Motivos que fizeram com que procurasse o Programa, por sexo

\begin{tabular}{|l|c|c|}
\hline \multicolumn{1}{|c|}{ MOTIVOS } & HOMENS & MULHERES \\
\hline $\begin{array}{l}\text { Ter um diploma escolar para } \\
\text { melhorar o emprego }\end{array}$ & 27 & 22 \\
\hline $\begin{array}{l}\text { Fazer um curso } \\
\text { profissionalizante para } \\
\text { melhorar no trabalho }\end{array}$ & 23 & 25 \\
\hline $\begin{array}{l}\text { Ter o diploma escolar e do } \\
\text { curso profissionalizante para } \\
\text { melhorar a situação do emprego }\end{array}$ & 26 & 22 \\
\hline $\begin{array}{l}\text { Adquirir novos conhecimentos } \\
\text { das disciplinas escolares }\end{array}$ & 24 & 21 \\
\hline $\begin{array}{l}\text { Adquirir novos conhecimentos } \\
\text { profissionais }\end{array}$ & 22 & 13 \\
\hline $\begin{array}{l}\text { Estar em um lugar de bom } \\
\text { convívio social }\end{array}$ & 16 & 11 \\
\hline $\begin{array}{l}\text { Ter uma outra atividade fora de } \\
\text { casa }\end{array}$ & 14 & 07 \\
\hline $\begin{array}{l}\text { Aprender algo que seja } \\
\text { diferente do seu trabalho }\end{array}$ & 19 & - \\
\hline $\begin{array}{l}\text { Voltar à atividade depois de } \\
\text { problema de saúde }\end{array}$ & 01 & - \\
\hline Entrar na faculdade & 01 & 01 \\
\hline Ser um bom profissional & - & - \\
\hline $\begin{array}{l}\text { Concluir o ensino fundamental } \\
\text { e médio em pouco tempo }\end{array}$ & - & \\
\hline $\begin{array}{l}\text { Para dar continuidade aos } \\
\text { estudos }\end{array}$ & 01 & \\
\hline & & \\
\hline
\end{tabular}


Fazer um curso de enfermagem

19. Há relação entre os conhecimentos escolares e os exigidos no trabalho

Por sexo

\begin{tabular}{|c|c|c|c|c|}
\hline SEXO & SIM & NÃO & $\begin{array}{c}\text { Não } \\
\text { respondeu }\end{array}$ & Não sabe \\
\hline feminino & 29 & 10 & 02 & 01 \\
\hline masculino & 29 & 05 & 03 & - \\
\hline
\end{tabular}

Por nível

\begin{tabular}{|c|c|c|c|c|}
\hline NÍVEL & SIM & NÃO & $\begin{array}{c}\text { Não } \\
\text { respondeu }\end{array}$ & Não sabe \\
\hline fundamental & 30 & 10 & 05 & 01 \\
\hline médio & 29 & 04 & - & - \\
\hline
\end{tabular}

Quais, por sexo

\begin{tabular}{|c|c|c|}
\hline CONHECIMENTOS & HOMENS & MULHERES \\
\hline Não respondeu & 02 & 01 \\
\hline $\begin{array}{l}\text { Comentário geral, sem } \\
\text { especificação }\end{array}$ & 04 & 06 \\
\hline Melhora a teoria e a prática & 02 & - \\
\hline $\begin{array}{l}\text { Ajuda no trabalho na } \\
\text { indústria }\end{array}$ & 01 & 01 \\
\hline Conseguir fazer um concurso & 02 & - \\
\hline $\begin{array}{l}\text { Qualquer serviço exige } \\
\text { noções de elétrica }\end{array}$ & 02 & - \\
\hline $\begin{array}{l}\text { Relacionamento profissional } \\
\text { e familiar }\end{array}$ & 01 & - \\
\hline $\begin{array}{l}\text { Melhora a expressão no } \\
\text { português }\end{array}$ & 04 & 03 \\
\hline Melhora a escrita & 03 & 04 \\
\hline $\begin{array}{l}\text { Em matemática, informática } \\
\text { e português }\end{array}$ & 01 & 01 \\
\hline $\begin{array}{l}\text { Em matemática e na } \\
\text { qualificação profissional }\end{array}$ & 01 & - \\
\hline Na qualificação profissional & 02 & 05 \\
\hline Auxilia nos cálculos & 03 & 03 \\
\hline $\begin{array}{l}\text { É preciso ter mais } \\
\text { conhecimento na função de } \\
\text { líder }\end{array}$ & 01 & - \\
\hline
\end{tabular}




\begin{tabular}{|l|c|c|}
\hline Conhecer informática & 02 & - \\
\hline $\begin{array}{l}\text { Preencher uma ficha de } \\
\text { emprego }\end{array}$ & 01 & - \\
\hline $\begin{array}{l}\text { Saber se comportar em uma } \\
\text { entrevista }\end{array}$ & 01 & - \\
\hline Prestar atenção & 01 & 04 \\
\hline Viver em grupo & 01 & 01 \\
\hline Companheirismo & & - \\
\hline Escola "legitima" a pessoa & 01 & - \\
\hline Conseguir emprego & 01 & 01 \\
\hline $\begin{array}{l}\text { Comentário não relacionado } \\
\text { com a questão }\end{array}$ & - & 01 \\
\hline Respeito e amizade & 01 & 01 \\
\hline Ajuda a conseguir emprego & 01 & 01 \\
\hline Na área da saúde & - & 02 \\
\hline Conseguir emprego melhor & - & 01 \\
\hline Postura profissional & - & - \\
\hline
\end{tabular}

Quais, por nível

\begin{tabular}{|l|c|c|}
\hline \multicolumn{1}{|c|}{ CONHECIMENTOS } & FUNDAMENTAL & MÉDIO \\
\hline Não respondeu & 03 & 09 \\
\hline $\begin{array}{l}\text { Comentário geral, sem } \\
\text { especificação }\end{array}$ & 01 & 01 \\
\hline Melhora a teoria e a prática & - & 01 \\
\hline $\begin{array}{l}\text { Ajuda no trabalho na } \\
\text { indústria }\end{array}$ & 01 & 01 \\
\hline Conseguir fazer um concurso & - & 02 \\
\hline $\begin{array}{l}\text { Qualquer serviço exige } \\
\text { noções de elétrica }\end{array}$ & - & 01 \\
\hline $\begin{array}{l}\text { Relacionamento profissional } \\
\text { e familiar }\end{array}$ & - & 05 \\
\hline $\begin{array}{l}\text { Melhora a expressão no } \\
\text { português }\end{array}$ & 03 & 02 \\
\hline Melhora a escrita & 04 & 02 \\
\hline $\begin{array}{l}\text { Em matemática, informática } \\
\text { e português }\end{array}$ & - & 01 \\
\hline $\begin{array}{l}\text { Em matemática e na } \\
\text { qualificação profissional }\end{array}$ & - & 04 \\
\hline Na qualificação profissional & 03 & 02 \\
\hline Auxilia nos cálculos & - & 01 \\
\hline $\begin{array}{l}\text { É preciso ter mais } \\
\text { conhecimento na função de } \\
\text { líder }\end{array}$ & & - \\
\hline
\end{tabular}




\begin{tabular}{|l|c|c|}
\hline Conhecer informática & 02 & - \\
\hline $\begin{array}{l}\text { Preencher uma ficha de } \\
\text { emprego }\end{array}$ & 01 & - \\
\hline $\begin{array}{l}\text { Saber se comportar em uma } \\
\text { entrevista }\end{array}$ & 01 & - \\
\hline Prestar atenção & 01 & 01 \\
\hline Viver em grupo & 04 & - \\
\hline Companheirismo & 01 & - \\
\hline Escola "legitima" a pessoa & 01 & - \\
\hline Conseguir emprego & 01 & - \\
\hline $\begin{array}{l}\text { Comentário não relacionado } \\
\text { com a questão }\end{array}$ & 01 & - \\
\hline Respeito e amizade & 02 & - \\
\hline Ajuda a conseguir emprego & 02 & - \\
\hline Na área da saúde & 01 & 01 \\
\hline Conseguir emprego melhor & 02 & - \\
\hline Postura profissional & - & \\
\hline
\end{tabular}

20. Contribuição dos conhecimentos escolares com a vida, por Centro

\begin{tabular}{|l|c|c|c|}
\hline \multicolumn{1}{|c|}{ CONHECIMENTOS } & $\begin{array}{c}\text { Armando } \\
\text { Mazzo }\end{array}$ & $\begin{array}{c}\text { Julio de } \\
\text { Grammont }\end{array}$ & $\begin{array}{c}\text { Valdemar } \\
\text { Mattei }\end{array}$ \\
\hline Não contribui & 01 & 01 & - \\
\hline Não respondeu & 01 & 01 & - \\
\hline Nas tarefas profissionais & 01 & 02 & 04 \\
\hline Abriu perspectiva de novos cursos & 01 & - & - \\
\hline Melhora a vida pessoal e profissional & 01 & - & - \\
\hline Melhora a situação cultural e profissional & 01 & - & 01 \\
\hline Comentário geral, sem especificação & 02 & 13 & 05 \\
\hline Ajuda a procurar emprego & 01 & - & - \\
\hline Ajuda a conseguir emprego & - & 01 & 01 \\
\hline Melhora no português e na profissão & 01 & - & - \\
\hline Melhora na expressão oral e escrita & 01 & 02 & 02 \\
\hline Ajuda a prestar concurso público & 01 & - & - \\
\hline $\begin{array}{l}\text { Ajuda a prestar concurso público, vestibular } \\
\text { e na faculdade }\end{array}$ & 01 & - & - \\
\hline Melhora no português e na matemática & 01 & 01 & - \\
\hline Garante atualização & 01 & 02 & 02 \\
\hline Nas disciplinas escolares & 01 & - & - \\
\hline Melhora a expressão & 01 & 02 & 01 \\
\hline $\begin{array}{l}\text { Aprendeu que tem direitos e que pode cobrá- } \\
\text { los }\end{array}$ & 01 & - & - \\
\hline
\end{tabular}




\begin{tabular}{|l|c|c|c|}
\hline $\begin{array}{l}\text { Auxilia no programa de qualidade total ISO } \\
\text { 9000/2000 (?) }\end{array}$ & 01 & - & - \\
\hline $\begin{array}{l}\text { Aplicar na vida cotidiana os conhecimentos } \\
\text { adquiridos na qualificação profissional }\end{array}$ & 01 & - & - \\
\hline A escola ensina mais que a via "lá fora" & 01 & - & - \\
\hline Comentário não relacionado com a questão & 01 & - & - \\
\hline Melhora da auto-estima & 01 & 02 & - \\
\hline $\begin{array}{l}\text { Mudança de como a família e os amigos o } \\
\text { vêem }\end{array}$ & 01 & - & \\
\hline Estimulou a vontade de aprender mais & 01 & - & - \\
\hline Tem mais informação & - & 03 & - \\
\hline Nova visão de mundo & - & 01 & - \\
\hline Calcular & - & 03 & - \\
\hline Navegar na internet & - & 02 & 01 \\
\hline Trabalhar em grupo & - & 01 & - \\
\hline Desenvolver as idéias & - & 04 & - \\
\hline Perder o medo de participar das atividades & - & 01 & - \\
\hline Melhorar o currículo pessoal & - & 01 & 01 \\
\hline Melhorar o vocabulário & - & 01 & - \\
\hline Conhecer informática & - & 01 & - \\
\hline $\begin{array}{l}\text { Perder o preconceito em relação aos mais } \\
\text { velhos }\end{array}$ & - & 01 & - \\
\hline Ajudar os filhos & - & 01 & - \\
\hline A escola é uma distração & & - & - \\
\hline
\end{tabular}

21. Como o curso de qualificação pode ajudar na vida, por Centro

\begin{tabular}{|l|c|c|c|}
\hline \multicolumn{1}{|c|}{ CONHECIMENTO } & $\begin{array}{c}\text { Armando } \\
\text { Mazzo }\end{array}$ & $\begin{array}{c}\text { Julio de } \\
\text { Grammont }\end{array}$ & $\begin{array}{c}\text { Valdemar } \\
\text { Mattei }\end{array}$ \\
\hline Não contribui & - & 02 & - \\
\hline Não respondeu & 01 & - & - \\
\hline Resposta não se relaciona com a questão & & & 02 \\
\hline Melhorar o que você já faz em seu trabalho & 11 & 15 & 06 \\
\hline Mudar de ramo, tentar um trabalho novo & 09 & 17 & 05 \\
\hline Ter uma profissão reconhecida & 09 & 22 & 10 \\
\hline $\begin{array}{l}\text { Ter a possibilidade de ter um trabalho e } \\
\text { gerar renda como autônomo }\end{array}$ & 13 & 17 & 10 \\
\hline Entrar em uma associação ou cooperativa & 02 & 05 & 03 \\
\hline $\begin{array}{l}\text { Acompanhar os novos conceitos exigidos pelo } \\
\text { mercado de trabalho }\end{array}$ & 01 & - & - \\
\hline $\begin{array}{l}\text { Conseguir um emprego em uma } \\
\text { multinacional }\end{array}$ & 01 & - & - \\
\hline
\end{tabular}




\begin{tabular}{|l|c|c|c|}
\hline $\begin{array}{l}\text { Melhorar o relacionamento com as outras } \\
\text { pessoas }\end{array}$ & - & - & 01 \\
\hline Trabalhar como voluntário & - & - & 01 \\
\hline
\end{tabular}

22. Diferença entre profisssão, trabalho e emprego, no conjunto

\begin{tabular}{|c|c|c|}
\hline Há diferença & Não há diferença & Não respondeu \\
\hline 51 & 20 & 05 \\
\hline
\end{tabular}

Conseguiram definir melhor a profissão do que emprego e trabalho

Entre os que definem diferenças:

\begin{tabular}{|l|l|}
\hline Não conseguiram explicitar a diferença & 03 \\
\hline Trabalho e emprego são a mesma coisa & 09 \\
\hline
\end{tabular}

Profissão

\begin{tabular}{|l|c|}
\hline \multicolumn{1}{|c|}{ DEFINIÇÃO } & NÚMERO \\
\hline Dentista é uma profissão & 01 \\
\hline É o que se pode escolher & 04 \\
\hline É o que está na carteira & 04 \\
\hline Algo que se pode ter pelo conhecimento & 04 \\
\hline Traz melhores oportunidades & 01 \\
\hline Está relacionada com estudo (escola) & 05 \\
\hline Nem sempre é o que se quer & 01 \\
\hline Traz maior reconhecimento e salário & 02 \\
\hline $\begin{array}{l}\text { É o que traz reconhecimento e prazer em } \\
\text { fazer }\end{array}$ & 02 \\
\hline É o que se faz por prazer & 03 \\
\hline Não é todo mundo que tem & 01 \\
\hline É o que se tem durante muitos anos & 02 \\
\hline É capacidade & 01 \\
\hline Especializar-se na área desejada & 05 \\
\hline $\begin{array}{l}\text { É o que todos querem ter e nem sempre } \\
\text { conseguem }\end{array}$ & 01 \\
\hline É o que se luta durante vários anos para ter & 03 \\
\hline $\begin{array}{l}\text { É aquilo a que você se dedica e nem sempre } \\
\text { pratica }\end{array}$ & 01 \\
\hline $\begin{array}{l}\text { É o que se sabe fazer, o que se aprende a } \\
\text { fazer }\end{array}$ & 04 \\
\hline É para a vida toda & 01 \\
\hline Se adquire com curso profissionalizante & 02 \\
\hline
\end{tabular}




\begin{tabular}{|l|l|}
\hline É trabalho com registro & 01 \\
\hline É algo que nos preenche & 01 \\
\hline É qualificação & 02 \\
\hline É o que você tem certificado & 01 \\
\hline É uma carreira & 01 \\
\hline
\end{tabular}

Trabalho

\begin{tabular}{|c|c|}
\hline DEFINIÇÃO & NÚMERO \\
\hline Ficar fazendo alguma coisa & 01 \\
\hline Aquilo que é obrigado a fazer & 01 \\
\hline Algo importante para a vida & 01 \\
\hline É vontade e esforço & 01 \\
\hline Esforço e cansaço & 01 \\
\hline Não precisa de estudo & 01 \\
\hline Todo mundo tem & 01 \\
\hline Hoje só conheço o informal & 01 \\
\hline É obrigação & 03 \\
\hline É a atividade do dia a dia & 01 \\
\hline É o que dá o salário & 01 \\
\hline É limpar a casa no final de semana & 01 \\
\hline Fazer o que dá certo & 01 \\
\hline É o que consegue fazer por algum tempo & 01 \\
\hline É o que aparece quando está desempregado & 03 \\
\hline É tudo aquilo que me ocupa & 01 \\
\hline É a sobrevivência & 01 \\
\hline É tudo que se vai fazer e precisa ser feito & 01 \\
\hline Algo que temos que ter & 01 \\
\hline É algo que não se tem opção & 02 \\
\hline Aprende fazendo & 01 \\
\hline Não exige estudo & 01 \\
\hline É o que traz dignidade & 01 \\
\hline Exercer sua carreira & 01 \\
\hline Não precisa de qualificação & 01 \\
\hline
\end{tabular}

Emprego

\begin{tabular}{|l|c|}
\hline \multicolumn{1}{|c|}{ DEFINIÇÃO } & NÚMERO \\
\hline Trabalhar em banco é emprego & 01 \\
\hline É o que querem que você faça & 01 \\
\hline É de onde vem o salário & 01 \\
\hline
\end{tabular}




\begin{tabular}{|l|l|}
\hline É o registro na carteira & 05 \\
\hline É o mais importante & 01 \\
\hline É oportunidade & 02 \\
\hline É o que se faz todo dia, rotina & 01 \\
\hline Não precisa de estudo & 01 \\
\hline Resultado de busca pessoal & 01 \\
\hline É obrigação & 01 \\
\hline $\begin{array}{l}\text { É o que garante o salário mesmo que não } \\
\text { goste da atividade }\end{array}$ & 02 \\
\hline É o que ainda não encontrei & 01 \\
\hline É trabalhar e receber & 03 \\
\hline É um trabalho qualquer, do momento & 01 \\
\hline Fazer o que dá certo, o que aparece & 03 \\
\hline É onde você faz uma atividade & 01 \\
\hline É a meta de quem está parado & 01 \\
\hline É o que você trabalha porque precisa & 03 \\
\hline É o que vai conhecer e aprender & 01 \\
\hline Não exige estudo & 01 \\
\hline É segurança & 01 \\
\hline
\end{tabular}

23. Pretensão em atuar na área da qualificação cursada

Informática - ensino fundamental

\begin{tabular}{|c|c|c|}
\hline Pretendem & Não pretendem & $\begin{array}{c}\text { Não respondeu ou } \\
\text { ficou vago }\end{array}$ \\
\hline 03 & 02 & 03 \\
\hline
\end{tabular}

Entre os que não pretendem, áreas apontadas como possibilidades

\begin{tabular}{|l|c|}
\hline \multicolumn{1}{|c|}{ ÁREAS } & NÚMERO \\
\hline Continuar a ser montador de cadeiras & 01 \\
\hline voluntariado & 01 \\
\hline Comércio (bazar ou loja) & 01 \\
\hline
\end{tabular}

Informática - ensino médio

\begin{tabular}{|c|c|}
\hline pretendem & Não pretendem \\
\hline 05 & 02 \\
\hline
\end{tabular}


Entre os que não pretendem, áreas apontadas como possibilidades

\begin{tabular}{|l|c|}
\hline \multicolumn{1}{|c|}{ ÁREAS } & NÚMERO \\
\hline saúde & 01 \\
\hline nutrição & 01 \\
\hline
\end{tabular}

Comércio e serviços - ensino fundamental

áreas apontadas como possibilidades

\begin{tabular}{|l|c|}
\hline \multicolumn{1}{|c|}{ ÁREAS } & NÚMERO \\
\hline Não respondeu & 05 \\
\hline nenhuma & 01 \\
\hline Qualquer uma desde que seja registrada & 01 \\
\hline enfermagem & 01 \\
\hline informática & 03 \\
\hline Corte e costura & 02 \\
\hline nutrição & 07 \\
\hline radiologia & 01 \\
\hline Construção civil & 01 \\
\hline estética & 04 \\
\hline administrativa & 01 \\
\hline Médico legista & 01 \\
\hline saúde & 01 \\
\hline cabeleireiro & 01 \\
\hline
\end{tabular}

Estética - ensino médio

\begin{tabular}{|c|c|}
\hline pretendem & Não pretendem \\
\hline 07 & 02 \\
\hline
\end{tabular}

Entre os que não pretendem, áreas apontadas como possibilidades

\begin{tabular}{|l|c|}
\hline \multicolumn{1}{|c|}{ ÁREAS } & NÚMERO \\
\hline Recursos humanos & 01 \\
\hline Gestão política & 01 \\
\hline
\end{tabular}

Construção civil - ensino fundamental

áreas apontadas como possibilidades

\begin{tabular}{|l|c|}
\hline \multicolumn{1}{|c|}{ ÁREAS } & NÚMERO \\
\hline Não respondeu & 01 \\
\hline enfermagem & 01 \\
\hline
\end{tabular}




\begin{tabular}{|l|l|}
\hline direito & 01 \\
\hline informática & 02 \\
\hline Construção civil & 01 \\
\hline "sabe Deus" & 01 \\
\hline
\end{tabular}

Construção Civil - ensino médio

\begin{tabular}{|c|c|c|}
\hline pretendem & Não pretendem & Não respondeu \\
\hline 13 & 03 & 01 \\
\hline
\end{tabular}

Entre os que não pretendem, áreas apontadas como possibilidades

\begin{tabular}{|l|c|}
\hline \multicolumn{1}{|c|}{ ÁREAS } & NÚMERO \\
\hline Eletrônica & 01 \\
\hline Funcionalismo público & 01 \\
\hline Podologia & 01 \\
\hline
\end{tabular}

24. Mudança na visão de sociedade a partir do que estão aprendendo no Programa, no conjunto dos alunos

\begin{tabular}{|l|c|}
\hline \multicolumn{1}{|c|}{ VISÃO } & NÚMERO \\
\hline Não mudou & 14 \\
\hline Não respondeu & 08 \\
\hline Resposta vaga ou incompleta & 01 \\
\hline Espera que a sociedade melhore (AM) & 03 \\
\hline $\begin{array}{l}\text { Adquiriu melhores conhecimentos na } \\
\text { área(AM) }\end{array}$ & 02 \\
\hline Adquiriu confiança com os estudos(AM)(JG) & 01 \\
\hline $\begin{array}{l}\text { Concluir o ensino médio e se aperfeiçoar na } \\
\text { área(AM) }\end{array}$ & 01 \\
\hline $\begin{array}{l}\text { Adquiriu visão mais ampla da } \\
\text { sociedade(AM) }\end{array}$ & 01 \\
\hline Estudando nas profissões que gosta(AM) & 01 \\
\hline $\begin{array}{l}\text { No voto, maneira de agir, sociedade pode ser } \\
\text { coerente ou hipócrita(AM) }\end{array}$ & 01 \\
\hline $\begin{array}{l}\text { Sem escolaridade a pessoa se sente afastado } \\
\text { da comunidade estudada(AM) }\end{array}$ & 01 \\
\hline Aprendeu que há vários tipos de classe(AM) & 01 \\
\hline Ajudar os filhos nas atividades em casa(AM) & 01 \\
\hline $\begin{array}{l}\text { Aprendeu coisas que na vida ainda não tinha } \\
\text { aprendido(AM) }\end{array}$ & 01 \\
\hline $\begin{array}{l}\text { Com estudo e esforço a sociedade recebe } \\
\text { melhor(AM) }\end{array}$ & \\
\hline
\end{tabular}




\begin{tabular}{|c|c|}
\hline "abriu a mente"(JG) & 02 \\
\hline $\begin{array}{l}\text { Conhecimentos ajudam na vida e no } \\
\text { trabalho(JG) }\end{array}$ & 02 \\
\hline Maneira de agir, pensar e falar(JG)(VM) & 02 \\
\hline $\begin{array}{l}\text { Mostrar o trabalho que fazem para a } \\
\text { sociedade(JG) }\end{array}$ & 01 \\
\hline Não se está sozinho(JG) & 01 \\
\hline $\begin{array}{l}\text { União entre as pessoas e conviver com os } \\
\text { defeitos dos outros(JG) }\end{array}$ & 03 \\
\hline Resgatou dignidade (JG) & 02 \\
\hline Adquiriu gosto pelo estudo(JG) & 01 \\
\hline Resgatou juventude e gosto pela vida(JG) & 01 \\
\hline $\begin{array}{l}\text { Melhorou o relacionamento com as } \\
\text { pessoas }(\mathrm{JG})(\mathrm{VM})\end{array}$ & 06 \\
\hline $\begin{array}{l}\text { Podemos aprender e ensinar aos } \\
\text { outros(JG)(VM) }\end{array}$ & 01 \\
\hline Mexer no computador(JG)(VM) & 02 \\
\hline Não ter preconceito(JG) & 01 \\
\hline $\begin{array}{l}\text { Entendeu melhor a política, passou a ler } \\
\text { jornais(JG) }\end{array}$ & 01 \\
\hline $\begin{array}{l}\text { Visão diferente despertou interesse em } \\
\text { mudar de ramo(JG) }\end{array}$ & 01 \\
\hline $\begin{array}{l}\text { A escola mudou muito de um tempo para } \\
\text { cá(JG) }\end{array}$ & 01 \\
\hline $\begin{array}{l}\text { As pessoas perguntam sobre as novidades no } \\
\text { embelezamento(JG) }\end{array}$ & 01 \\
\hline $\begin{array}{l}\text { Voltar a estudar mudou a forma de ver a si } \\
\text { própria(JG) }\end{array}$ & 01 \\
\hline Possibilidade de seguir na carreira(JG) & 01 \\
\hline Hoje pensa que todo mundo é capaz(JG) & 01 \\
\hline $\begin{array}{l}\text { Aprendeu a não se sentir menor que os } \\
\text { outros(VM) }\end{array}$ & 01 \\
\hline $\begin{array}{l}\text { Aprendeu a valorizar a política e outras } \\
\text { profissões(VM) }\end{array}$ & 01 \\
\hline Acompanhar a evolução tecnológica(VM) & 01 \\
\hline Ficou mais calmo e educado(VM) & 01 \\
\hline Fez muitas amizades(VM) & 02 \\
\hline $\begin{array}{l}\text { O conhecimento é melhor para o } \\
\text { mercado(VM) }\end{array}$ & 01 \\
\hline Respeitar normas(VM) & 01 \\
\hline Internet(VM) & 01 \\
\hline Mudar de profissão(VM) & 01 \\
\hline
\end{tabular}


25. Mudança nos planos pessoais a partir do que estão aprendendo no Programa, no conjunto dos alunos

\begin{tabular}{|c|c|}
\hline VISÃO & NÚMERO \\
\hline Não mudou & 08 \\
\hline Não respondeu & 09 \\
\hline $\begin{array}{l}\text { Resposta vaga, não relacionada diretamente } \\
\text { a questão(JG) }\end{array}$ & 07 \\
\hline Especializar-se na área escolhida (AM) & 01 \\
\hline Fazer novos cursos apesar da idade(AM) & 01 \\
\hline $\begin{array}{l}\text { Conhecimentos adquiridos deram outro } \\
\text { valor(AM) }\end{array}$ & 01 \\
\hline Ampliou os conhecimentos(AM)(JG) & 02 \\
\hline Pretende montar uma micro empresa(AM) & 01 \\
\hline Ampliou os conhecimentos profissionais(AM) & 03 \\
\hline Antes não sabia o que fazer(AM) & 01 \\
\hline $\begin{array}{l}\text { Conhecimentos auxiliar a colocar em prática } \\
\text { o que gosta(AM)(JG) }\end{array}$ & 01 \\
\hline Fazer curso superior(AM)(JG)(VM) & 07 \\
\hline Trabalhar como autônomo(AM)(JG) & 02 \\
\hline $\begin{array}{l}\text { Aumentando a escolaridade melhorar a } \\
\text { situação financeira(AM) }\end{array}$ & 02 \\
\hline Posso adquirir mais conhecimento(AM) & 01 \\
\hline $\begin{array}{l}\text { Informática o tornou uma pessoa mais } \\
\text { dinâmica(AM) }\end{array}$ & 01 \\
\hline $\begin{array}{l}\text { Aprendeu coisas que na vida ainda não tinha } \\
\text { aprendido(AM)(JG) }\end{array}$ & 02 \\
\hline $\begin{array}{l}\text { Com certificado dá para lutar por uma } \\
\text { profissão(JG) }\end{array}$ & 01 \\
\hline $\begin{array}{l}\text { Conquistou uma situação que não tinha } \\
\text { antes(JG) }\end{array}$ & 01 \\
\hline Continuar os estudos apesar da idade(JG) & 01 \\
\hline Conquistar novas coisas apesar da idade(JG) & 02 \\
\hline Fazer algo diferente do que faz(JG) & 01 \\
\hline Viver em união e compartilhar(JG) & 01 \\
\hline Adquirir um trabalho melhor(JG) & 01 \\
\hline Buscar coisas melhores(JG) & 03 \\
\hline Olhar o futuro de outra forma(JG) & 01 \\
\hline Vontade de ampliar os conhecimentos(JG) & 02 \\
\hline Matemática ajuda no dia a dia(JG) & 01 \\
\hline Melhorou a auto-confiança(JG)(VM) & 03 \\
\hline $\begin{array}{l}\text { Tornar-se um profissional e ter o próprio } \\
\text { negócio(JG) }\end{array}$ & 01 \\
\hline
\end{tabular}




\begin{tabular}{|l|l|}
\hline Tornar-se um profissional(VM) & 01 \\
\hline Arrumar trabalho,emprego(JG)(VM) & 03 \\
\hline Gostou da profissão escolhida(JG) & 01 \\
\hline Mudar de profissão(JG) & 01 \\
\hline Especializar-se na área(JG) & 01 \\
\hline Fez muitas amizades(VM) & 01 \\
\hline Desenvolveu o raciocínio(VM) & 01 \\
\hline
\end{tabular}

26. Apreensão de instrumentos que possibilitem autonomia na busca de conhecimentos pessoais e profissionais, no conjunto dos alunos

\begin{tabular}{|l|c|c|c|c|c|c|}
\hline \multicolumn{1}{|c|}{ INSTRUMENTOS } & $\mathbf{1}^{\mathbf{0}}$ & $\mathbf{2}^{\mathbf{0}}$ & $\mathbf{3}^{\mathbf{0}}$ & $\mathbf{4}^{\mathbf{0}}$ & $\mathbf{5}^{\mathbf{0}}$ & $\mathbf{6}^{\mathbf{0}}$ \\
\hline $\begin{array}{l}\text { Consegue buscar informação em jornais, } \\
\text { revistas, dicionários, livros, etc. }\end{array}$ & 27 & 06 & 03 & 03 & 03 & 05 \\
\hline $\begin{array}{l}\text { Consegue acessar a Internet e buscar a } \\
\text { informação necessária }\end{array}$ & 26 & 16 & 02 & 05 & 05 & - \\
\hline $\begin{array}{l}\text { Consegue montar um currículo e enviar aos } \\
\text { locais adequados }\end{array}$ & 07 & 18 & 17 & 06 & 01 & - \\
\hline $\begin{array}{l}\text { Conhece ou sabe buscar a legislação para } \\
\text { abrir negócio próprio }\end{array}$ & 03 & 08 & 09 & 07 & 02 & 04 \\
\hline $\begin{array}{l}\text { Sabe onde buscar seus direitos ao sentir-se } \\
\text { prejudicado em alguma situação }\end{array}$ & 10 & 15 & 12 & 09 & 05 & 01 \\
\hline $\begin{array}{l}\text { Consegue reunir informações de diferentes } \\
\text { fontes e elaborar uma conclusão própria do } \\
\text { conhecimento procurado }\end{array}$ & 18 & 05 & 05 & 05 & 05 & 08 \\
\hline Não respondeu & 02 & & & & & \\
\hline
\end{tabular}

1* só dicionário

27. Contribuição da escola na construção da autonomia, no conjunto dos alunos

\begin{tabular}{|l|c|}
\hline \multicolumn{1}{|c|}{ CONTRIBUIÇÃO } & NÚMERO \\
\hline Não conseguiu definir & 35 \\
\hline Não respondeu & 02 \\
\hline A escola não ajudou & 05 \\
\hline Informação adequada a situação & 02 \\
\hline Informação dos professores & 04 \\
\hline Conhecimentos e atualização & 02 \\
\hline Matemática e português & 01 \\
\hline Informática & 05 \\
\hline Lê e escreve mais & 02 \\
\hline Trabalho em grupo & 01 \\
\hline
\end{tabular}




\begin{tabular}{|l|l|}
\hline Melhorou a leitura & 04 \\
\hline Estímulo & 05 \\
\hline Informação sobre os direitos & 01 \\
\hline Onde pesquisar o que se quer & 02 \\
\hline Mexer na internet & 05 \\
\hline Montar um currículo & 01 \\
\hline Questionamentos que a escola colocava & 02 \\
\hline Explorar a leitura de jornais e revistas & 02 \\
\hline Debates & 01 \\
\hline Elaboração de projeto & 01 \\
\hline Entender as leis & 01 \\
\hline
\end{tabular}

28. Motivos que prejudiquem a freqüência diária à escola, por sexo

\begin{tabular}{|c|c|c|}
\hline MOTIVOS & HOMENS & MULHERES \\
\hline Horário do trabalho & 05 & 01 \\
\hline Não há nada que prejudique & 25 & 28 \\
\hline Não respondeu & 02 & - \\
\hline saúde & 02 & - \\
\hline $\begin{array}{l}\text { Problema com transporte } \\
\text { (falta de dinheiro) }\end{array}$ & 01 & 01 \\
\hline Hora extra no trabalho & - & 01 \\
\hline $\begin{array}{l}\text { Família, problemas } \\
\text { familiares }\end{array}$ & 01 & 02 \\
\hline $\begin{array}{l}\text { Tomar conta dos irmãos } \\
\text { para a mão trabalhar }\end{array}$ & - & 01 \\
\hline Idade & - & 01 \\
\hline Horário das aulas & - & 01 \\
\hline $\begin{array}{l}\text { Às vezes não há quem cuide } \\
\text { dos filhos }\end{array}$ & - & 04 \\
\hline $\begin{array}{l}\text { Distância entre a escola e a } \\
\text { casa }\end{array}$ & 01 & 03 \\
\hline Deixar a filha sozinha & - & 01 \\
\hline $\begin{array}{l}\text { O trabalho fica muito } \\
\text { distante da escola }\end{array}$ & - & 02 \\
\hline $\begin{array}{l}\text { Resolver o problema de } \\
\text { transporte }\end{array}$ & - & 01 \\
\hline $\begin{array}{l}\text { Escola continuar deixando } \\
\text { entrar atrasado }\end{array}$ & 01 & - \\
\hline
\end{tabular}


29. Soluções para os problemas apresentados, por sexo

\begin{tabular}{|l|c|c|}
\hline \multicolumn{1}{|c|}{ SOLUÇÕES } & HOMENS & MULHERES \\
\hline Não conseguiu definir & 04 & - \\
\hline $\begin{array}{l}\text { Colaborar com o aluno no } \\
\text { dia seguinte da falta }\end{array}$ & 01 & - \\
\hline $\begin{array}{l}\text { Auxílio das empresas de } \\
\text { onibus }\end{array}$ & 02 & 04 \\
\hline Não há solução & 01 & 01 \\
\hline $\begin{array}{l}\text { Não deixar a família te } \\
\text { impedir de vir à escola }\end{array}$ & - & 01 \\
\hline Começar a aula mais tarde & 01 & 11 \\
\hline $\begin{array}{l}\text { Que o ônibus da escola desse } \\
\text { menos volta }\end{array}$ & - & 01 \\
\hline Auxílio dos amigos & - & 01 \\
\hline Comprar um carro & - & 01 \\
\hline Pagar uma babá & - & - \\
\hline $\begin{array}{l}\text { Ter mais escolas } \\
\text { profissionalizantes }\end{array}$ & 01 & \\
\hline
\end{tabular}

30. Perspectiva para os próximos dois anos, por sexo

\begin{tabular}{|l|c|c|}
\hline \multicolumn{1}{|c|}{ PERSPECTIVA } & HOMENS & MULHERES \\
\hline $\begin{array}{l}\text { Ainda não pensou, não sabe } \\
\text { AM }\end{array}$ & 04 & 03 \\
\hline $\begin{array}{l}\text { Resposta não relacionada } \\
\text { com a questão AM JG VM }\end{array}$ & 03 & - \\
\hline Não respondeu AM & 02 & - \\
\hline $\begin{array}{l}\text { Continuar estudando AM } \\
\text { JG VM }\end{array}$ & 05 & 03 \\
\hline $\begin{array}{l}\text { Ter conclú́do um curso } \\
\text { técnico AM }\end{array}$ & 01 & 01 \\
\hline $\begin{array}{l}\text { Estar melhor que hoje AM } \\
\text { JG }\end{array}$ & 02 & 02 \\
\hline $\begin{array}{l}\text { Estar atuando na área de } \\
\text { qualificação cursada AM } \\
\text { JG }\end{array}$ & 01 & - \\
\hline $\begin{array}{l}\text { Trabalhar como autônomo } \\
\text { AM JG }\end{array}$ & 01 & - \\
\hline Fazer um curso técnico AM & 01 & 01 \\
\hline $\begin{array}{l}\text { Estar me estabilizando no } \\
\text { trabalho AM }\end{array}$ & 01 & \\
\hline $\begin{array}{l}\text { Prestar vestibular AM JG } \\
\text { VM }\end{array}$ & 02 & \\
\hline
\end{tabular}




\begin{tabular}{|l|c|c|}
\hline $\begin{array}{l}\text { Ter uma casa própria, cargo } \\
\text { de prestígio e estabilidade } \\
\text { financeira AM }\end{array}$ & 01 & - \\
\hline $\begin{array}{l}\text { Estar fazendo faculdade AM } \\
\text { JG VM }\end{array}$ & 04 & 05 \\
\hline $\begin{array}{l}\text { Concluir o ensino médio AM } \\
\text { JG VM }\end{array}$ & 07 & 01 \\
\hline Mudar de emprego JG & - & 03 \\
\hline $\begin{array}{l}\text { Fazer um curso em outra } \\
\text { área JG }\end{array}$ & - & 02 \\
\hline Fazer outros cursos JG & - & 02 \\
\hline Estar trabalhando JG VM & 01 & 01 \\
\hline Aposentar JG & - & - \\
\hline $\begin{array}{l}\text { Prestar concurso público } \\
\text { JG }\end{array}$ & 01 & 01 \\
\hline $\begin{array}{l}\text { Aperfeiçoar-se na área de } \\
\text { costura JG }\end{array}$ & - & 02 \\
\hline $\begin{array}{l}\text { Realizada profissionalmente } \\
\text { JG }\end{array}$ & - & 01 \\
\hline $\begin{array}{l}\text { Ter concluído curso de } \\
\text { podologia JG }\end{array}$ & - & 01 \\
\hline $\begin{array}{l}\text { Preparar para fazer } \\
\text { vestibular JG VM VM }\end{array}$ & \begin{tabular}{l} 
\\
\hline $\begin{array}{l}\text { Concluir o ensino } \\
\text { fundamental VM }\end{array}$
\end{tabular} & 02 \\
\hline
\end{tabular}

31. Perspectiva para os próximos cinco anos, por sexo

\begin{tabular}{|l|c|c|}
\hline \multicolumn{1}{|c|}{ PERSPECTIVA } & HOMENS & MULHERES \\
\hline Não respondeu AM & 02 & - \\
\hline $\begin{array}{l}\text { Ainda não sabem não pensou } \\
\text { VM }\end{array}$ & 01 & 04 \\
\hline $\begin{array}{l}\text { Estar melhor que hoje AM } \\
\text { JG }\end{array}$ & 06 & - \\
\hline $\begin{array}{l}\text { Trabalhar na área técnica } \\
\text { AM }\end{array}$ & 02 & - \\
\hline Aposentar AM & 01 & 01 \\
\hline $\begin{array}{l}\text { Estar em um emprego estável } \\
\text { AM JG }\end{array}$ & 04 & 01 \\
\hline $\begin{array}{l}\text { Resposta não relacionada } \\
\text { com a questão AM JG VM }\end{array}$ & 06 & 01 \\
\hline $\begin{array}{l}\text { Fazer outros curso } \\
\text { profissionalizantes AM VM }\end{array}$ & 01 & 02 \\
\hline $\begin{array}{l}\text { Estar estabelecido na } \\
\text { função, na área AM JG }\end{array}$ & 03 & 01 \\
\hline
\end{tabular}




\begin{tabular}{|c|c|c|}
\hline $\mathbf{V M}$ & & \\
\hline $\begin{array}{l}\text { Trabalhando no mesmo } \\
\text { ramo AM JG VM }\end{array}$ & 03 & 02 \\
\hline $\begin{array}{l}\text { Trabalhar como autônoma } \\
\text { VM }\end{array}$ & - & 02 \\
\hline Trabalhando AM JG VM & 01 & 01 \\
\hline $\begin{array}{l}\text { Trabalhando em novo ramo } \\
\text { AM JG VM }\end{array}$ & 01 & 02 \\
\hline $\begin{array}{l}\text { Trabalhar em algo que goste } \\
\text { JG }\end{array}$ & 01 & 01 \\
\hline $\begin{array}{l}\text { Aposentar como funcionária } \\
\text { pública JG }\end{array}$ & - & 01 \\
\hline $\begin{array}{l}\text { Ter concluído a faculdade de } \\
\text { pedagogia JG }\end{array}$ & - & 01 \\
\hline $\begin{array}{l}\text { Estar fazendo faculdade JG } \\
\text { VM }\end{array}$ & 03 & 06 \\
\hline $\begin{array}{l}\text { Ter concluído a faculdade } \\
\text { JG }\end{array}$ & - & 01 \\
\hline Ter uma profissão JG & 01 & - \\
\hline $\begin{array}{l}\text { Estar concluindo a faculdade } \\
\text { de medicina JG }\end{array}$ & 01 & - \\
\hline $\begin{array}{l}\text { Faculdade de enfermagem } \\
\text { JG }\end{array}$ & - & 01 \\
\hline $\begin{array}{l}\text { Estar fazendo faculdade de } \\
\text { gastronomia JG }\end{array}$ & - & 01 \\
\hline Estar aposentada JG & - & 01 \\
\hline Ser funcionário público JG & 01 & - \\
\hline $\begin{array}{l}\text { Produzir e vender roupas } \\
\text { JG }\end{array}$ & - & 01 \\
\hline Estar trabalhando JG & - & 01 \\
\hline $\begin{array}{l}\text { Ter concluído curso de } \\
\text { gestão pública JG }\end{array}$ & - & 01 \\
\hline $\begin{array}{l}\text { Realizada profissionalmente } \\
\text { JG }\end{array}$ & - & 01 \\
\hline $\begin{array}{l}\text { Ter concluído faculdade de } \\
\text { Educação física e estar } \\
\text { atuando JG }\end{array}$ & - & 01 \\
\hline $\begin{array}{l}\text { Ter montado clínica de } \\
\text { estética JG }\end{array}$ & - & 01 \\
\hline $\begin{array}{l}\text { Me empregar, deixar de ser } \\
\text { estagiária JG }\end{array}$ & - & 01 \\
\hline $\begin{array}{l}\text { Estar fazendo faculdade de } \\
\text { música VM }\end{array}$ & 01 & - \\
\hline $\begin{array}{l}\text { Ter concluído o ensino médio } \\
\text { VM }\end{array}$ & - & 02 \\
\hline
\end{tabular}




\title{
ANEXO 2 - ENTREVISTAS
}

\author{
$11 / 12 / 2007$
}

\section{ENTREVISTA - DET1}

Sandra: Por favor se apresenta, fala da sua formação, sua trajetória, sua experiência.

DET1: Bem eu sou..., sou natural de Alagoas, iniciei minha vida profissional na Bahia, sou graduado em filosofia e ciências jurídicas, fiz pós graduação em economia social e do trabalho pela UNICAMP e pela Pontifícia Universidade Católica de São Paulo, em nível de especialização as duas modalidades, uma outra pela Universidade Estadual da Bahia, escola de engenharia e o mestrado em economia do trabalho na UNICAMP. Iniciei minhas atividades profissionais como disse anteriormente no estado da Bahia, em empresas metalúrgicas, comecei a trabalhar com dezoito anos, dezoito para dezenove anos, e nesse momento já iniciei algumas atividades que tinham um cunho político, mais especificamente ingressei na comissão interna de prevenção de acidentes da metalúrgica, depois fui eleito para a comissão de fábrica, coordenei a comissão de fábrica por um certo período, depois sucessivamente eleito para o sindicato da categoria e para a confederação nacional dos metalúrgicos, da qual fui um dos fundadores, e fui o vice-presidente durante quatro anos. Logo após esse período fui fazer as complementações dos estudos na UNICAMP e depois vim para Santo André a convite do prefeito Celso Daniel para desenvolver atividades de formação por ele já conhecer um pouco da experiência que nós tínhamos implantado na confederação.

Sandra: O que você entende por educação popular?

DET1: A educação popular eu entendo como uma forma de educação se é que a gente pode dizer e afirmar que exista formas diferenciadas de educação, mas compreendo como uma educação mais arraigada no meio da sociedade, mais comprometida com os aspectos sociais, ou seja, não há uma separação do processo tipicamente acadêmico do processo mais vivencial das pessoas. Então a educação popular ela visa primordialmente, prioritariamente agregar esses dois elementos o social, o contexto real, social do qual as pessoas vivem e o contexto mais acadêmico da vida das pessoas.

Sandra: E pra você, a partir disso que você está colocando, qual que é o papel do poder público?

DET1: O poder público, a gente tem que compreender o poder público, como o catalisador, o aglutinador e catalisador das necessidades da sociedade. E a necessidade básica da sociedade passa exatamente pelo aspecto da educação. Não vejo a educação como muita gente coloca como um elemento de mobilidade social, mas a educação principalmente pelo aspecto da cidadania, pelo direito de conhecer, pelo direito do cidadão poder ler, escrever, interpretar, etc e ter uma outra visão de vida. Então vejo a educação com esse panorama não com o panorama exclusivo da mobilidade social, mesmo porque esta questão da mobilidade social imputado à educação, de que antes as pessoas eram pobres, eram miseráveis e conseguiram estudar e galgaram postos e conseguiram um bom emprego e conseguiram avançar na vida, isso é uma maneira que o sistema coloca de responsabilizar as pessoas pela sua própria ascensão, pelo seu próprio bem estar. É uma maneira de o Estado se omitir da sua obrigação de dizer que ele é o responsável de fornecer, de propiciar a educação a todas as pessoas. E quando se diz que a 
educação é a única maneira das pessoas terem essa mobilidade social, ele está jogando para as pessoas esta responsabilidade. Então a miséria existe porque as pessoas não tem educação, então o desemprego existe porque as pessoas estão mal preparadas, como nós estamos vendo recentemente esse alarido que a Globo tem feito e alguns órgãos do próprio Estado de que o problema do desemprego é que falta mão-de-obra qualificada, que falta pessoas qualificadas. Isso é uma falácia. Não é dizer que o trabalhador não precise de educação, ao contrário, precisa, mas reitero, nesse aspecto da cidadania, não como elemento determinante para a geração de emprego ou para sua empregabilidade.

Sandra: O objeto da pesquisa, para o qual sua entrevista está contribuindo, é o PIQ, que é o Programa Integrado de Qualificação. Eu pediria então a você que você definisse o que é o PIQ e como você vê o PIQ nessa relação com a educação popular, qual é o papel dele?

DET1: Isso, primeiramente, uma das grandes dificuldades que a educação teve no Brasil, foi conseguir romper com aquela lógica tradicional, que é inerente à lógica do capitalismo, do fazer, do entender e do fazer, do estudar e do trabalhar, essa tradicional dicotomia. A escola sempre foi preparada para que os cursos que eram oferecidos desde o período das artes, dos ofícios, os filhos dos pobres era preparados para trabalhar e os filhos dos ricos faziam os cursos mais propedêuticos para se bacharelar, direito, medicina, etc e o filho do pobre ia fazer sempre o curso de metalurgia, de artesanato, qualquer coisa que atendesse a essas necessidades do trabalho. Então essa dicotomia é feita pra justificar a concepção capitalista da história, o entendimento de que as classes sociais, posições tão definidas, e devem se manter naqueles parâmetros pelos quais foi traçado a concepção capitalista. E o rompimento desse processo, que ainda não se completou, porque ele é recorrente, sistematicamente a gente vê a propagação da lógica de que deve ter mais cursos profissionalizantes, as pessoas devem se preparar para o mercado de trabalho, é uma retomada daquela lógica anterior de manter essa dicotomia. No período mais recente, havia a possibilidade desde criação das escolas técnicas aqui no Brasil, no período mais recente, havia a possibilidade de você fazer os cursos agregando a formação profissional ao ensino mais propedêutico. Isso com Fernando Henrique Cardoso, se não me engano, a lei 8...8...11, isso, 2208, ele acabou isso, e voltou aquela lógica antiga, mesmo porque o entendimento de Fernando Henrique Cardoso era esse entendimento mais neo-liberal, de economia mais neo-liberal, e as escolas técnicas se fadaram a tendência de um fracasso, houve um esvaziamento completo das escolas técnicas, enquanto isso havia um certo fortalecimento do chamado sistema $S$, com uma concepção de escola em um certo sentido elitista, elitista porque há um corte preponderante no nível de escolaridade para as pessoas que ascendem àqueles cursos, além de ser um curso extremamente caro. Então quase que estudar em curso do sistema $\mathrm{S}$ significava a garantia de um emprego. Isso se remete um pouco à década de 70,80 , no início da década de 80 , no Brasil tinha um desenvolvimento econômico bastante significativo, com taxa de crescimento de 7 a $8 \%$, o chamado milagre brasileiro, e que chegou a uma situação chamado de pleno emprego, onde as pessoas não tinham dificuldade de conseguir postos de trabalho, tanto é assim que você via pessoas até sem o ensino, até não alfabetizadas assumindo posto de supervisão, encarregado, em empresas de ponta como era o setor automotivo, Volkswagen, a Scania, etc você encontrava muito isso. Isso daí também é um atestado, vem a comprovar e a contestar esse discurso anterior de que o emprego passa exatamente por essa preparação, por essa exigência de nível de escolaridade ou de formação profissional. Naquele período as próprias empresas preparavam as pessoas para assumir aquele posto mesmo que não fosse alfabetizada. Não quer dizer com isso que as pessoas devam se manter não alfabetizadas porque conseguiria, não, ao contrário, creio que para a indústria, para a sociedade, é interessante que as pessoas estejam preparadas, mas sem utilizar os absurdos que determinadas empresas utilizam que é exigir que uma pessoa, uma 
copeira, tenha o ensino médio, em absoluto, não tem necessidade de uma copeira ter o ensino médio, do ponto de vista da cidadania sim, é bom até que ela tenha a universidade, mas do ponto de vista da funcionalidade do trabalho não é necessário que ela tenha o ensino médio. $\mathrm{E}$ aí a gente vê as estatísticas das centrais de trabalho e renda, que estão com os jornais dizendo aí que existem tantas vagas que não foram preenchidas. Recentemente tivemos a oportunidade de ver uma dessas situações que foi o recrutamento aqui em Santo André de vagas para um empresa de telemarketing. Essa empresa de telemarketing de mais ou menos, penso de 200 pessoas que foram encaminhadas para fazer o exame ficaram dois ou três, porque ela exigia que a pessoa fosse poliglota, que a pessoa.., e é absolutamente inadmissível um tipo de exigência dessa natureza, eles fazem essa exigência e ao mesmo tempo eles não querem se comprometer com a formação de pessoas, eles já querem o quadro pronto, preparado, então o Estado tem que investir nisso e as empresas se beneficiam desse investimento do Estado sem ter o cuidado de também contribuir com essa formação dos trabalhadores. Essa formação dos trabalhadores só se dá nas indústrias mais de ponta, quando desenvolve as chamadas universidades corporativas, você vê grandes empresas que já desenvolvem esse processo, mesmo porque é uma especificidade do seu segmento produtivo. Mas como eu disse, anteriormente, a proposta que se desenhou aqui em Santo André, se desenhou exatamente pela falência do sistema que oferecesse essa formação integrada, como as Escolas Técnicas e até como os antigos Liceus de Artes e Ofícios, etc que faziam um pouco esse caminho. Porque o sistema S como eu disse também, ele tem um corte que em certo sentido ele é segregador, já que ele exige que as pessoas para fazerem um curso lá elas já tenham o ensino médio completo, no mínimo o ensino fundamental concluído. Então existia um gap entre esse público e o público efetivamente excluído das escolas, excluído do processo produtivo, terminando sendo excluído da própria sociedade, são jovens e adultos que não tiveram oportunidade de concluir seu curso em tempo próprio e por conta disso deixaram de freqüentar a escola, porque a escola, a escola como a gente tem formado, nossa escola hoje ela não é atrativa, então às vezes as pessoas dizem porque esse jovem poderia, não teria dificuldade de ter dado continuidade aos seus estudos, mas a escola também não é atrativa e em ela não sendo atrativa ela exclui esses alunos que procuram outras alternativas que possa satisfazer ao seu bem estar pessoal. Então o PIQ se desenhou na perspectiva de resgatar um pouco essa juventude, que seria além de oferecer essa escolaridade, oferecer também a oportunidade de fazer um curso profissionalizante, que tivesse identidade com ele, que ele se identificasse com aquela proposta. Então em vez de você fazer uma escola voltada especificamente para a tornearia, Santo André optou por fazer escolas em segmentos mais diversificados, então há a proposta de mais de 50 cursos diferenciados. As pessoas se identificam muito mais com essa proposta, e aí você vê quando se faz uma avaliação, um monitoramento de um curso dessa natureza ele tem um nível de evasão significativamente inferior aos que tem os mesmos cursos em nível nacional. Então hoje o nível de evasão...

Sandra: Você está falando curso de qualificação ou de escolaridade básica?

DET1: De escolaridade. Se você comparar, hoje de cada dez que entra no ensino fundamental, apenas três conseguem concluir esse ensino fundamental, então sete são excluídos. É um índice extremamente alto, se você for fazer esse levantamento no ensino médio, mais ainda essa situação. Então, assim, mais genericamente você tem quase $70 \%$ de evasão desses cursos do ensino fundamental, enquanto nós chegamos no patamar de $14,15 \%$ de evasão porque essa modalidade tem se mostrado uma modalidade mais atrativa, em que ele opta o que ele quer fazer e a construção desse itinerário é a possibilidade de ele ir se aprimorando e priorizar essa continuidade porque ele sabe que o módulo próximo que virá será um aperfeiçoamento daquele que ele já fez e ele se identifica com aquela proposta e com certeza ele prioriza se 
manter na escola. Então essa proposta é uma proposta que penso poderá ser expandida para outros segmentos, outros estados, porque efetivamente pensamos que contribuiria muito para a inclusão do jovem na escola.

Sandra: Você colocou algumas questões na sua resposta entre elas a questão dos jovens e dos itinerários. Essa vou deixar um pouco para frente. Queria que você falasse, no que é que se pauta a formatação do PIQ, porque a gente tem outras experiências próximas, similares, às vezes não realizada pelo poder público estatal, mas às vezes pela educação popular, mantida ou organizada pelos movimentos sociais ou pelas entidades sindicais. Então queria que você dissesse o PIQ bebe da onde? Ele tem alguns pressupostos que vem de alguma fonte, quais são elas?

DET1: Na verdade, vamos dizer assim que o PIQ foi uma construção espontânea, aqui em Santo André, mas a gente não pode deixar de referenciar alguns subsídios mais teóricos que a gente conhece, que a gente sabe pela experiência que deu resultado nesse sentido. Um pouco que a gente utilizou pra formatar o desenho inicial dessa proposta foi a própria experiência inicial da concepção social da história. A experiência do socialismo, no início a experiência da revolução soviética. A gente sabe que daquele período grandes educadores como Pistrak, Kaganov, Krupiskaia, todas essas pessoas naquela situação da revolução russa, quando o país era eminentemente agrário e até escravagista e de uma população semi analfabeta, para não dizer completamente analfabeta, esses educadores criaram esse experimento, essa experiência que pudesse agregar, não deslocar, o conhecer do fazer. E por necessidade da própria história, da própria situação do país, eles agregaram esses elementos que foi o ensino propedêutico do ensino profissionalizante aliado a monitoria desses alunos a prestar um serviço ao Estado e a sociedade com aquilo que eles conheceram, ou seja eles tinham a oportunidade de na escola trabalhar, aprender e levar o conhecimento, esse conhecimento que ele adquiriu para comunidades mais distantes, com menos condição de acessar a escola. Então, isso passando por aí da concepção dos educadores do Brasil principalmente o próprio Paulo Freire, Anísio Teixeira, educadores que, em que pese o Anísio Teixeira ter uma formação muito mais voltada para aquela concepção da escola nova, mas de toda sorte era algo revolucionário entendia que as pessoas tinham o direito do trabalho e que o Estado deveria envidar todos os esforços no sentido de propiciar aos seus cidadãos essa oportunidade. Então, isso daí é o que vamos chamar assim a inspiração inicial, mas na verdade essa construção se deu na equipe da Secretaria de educação, cada um sugerindo, propondo, etc numa construção conjunta, que por ser uma construção conjunta tenho certeza e a gente sente que todas as pessoas entendem e compreendem que participou dessa construção, e como ela foi uma construção democrática, sem sombra de dúvida será muito mais duradoura.

Sandra: Você falou dessa questão da, do panorama da união soviética imediatamente pósrevolução e a preocupação que eles tinha com o ensino propedêutico e com o fazer. Como você vê isso no PIQ?

DET1: no PIQ ...

Sandra: Qual é a relação da qualificação com os conhecimentos das diferentes áreas do conhecimento?

DET1: O problema que a gente tem aí no PIQ, porque o PIQ elegeu os três eixos fundamentais que seria o ensino propedêutico, a formação profissional e a monitoria, o estágio de monitoria. Infelizmente, aqui no nosso país a gente se esbarra em algumas questões 
burocráticas, infelizmente mesmo, o tribunal de contas no nosso país é quem define o que é educação. Então as despesas que por ventura a gente possa fazer pra educação, se o tribunal entender que aquilo não é educação, na compreensão deles, eles glosam e deixam as secretarias de educação com as mãos atadas porque eles entendem a educação do modo que eles querem compreender, aquela educação tradicional. Nada mais além disso. Então nós temos, possivelmente se terá, algumas dificuldades com essa coisa do Tribunal de Contas, mas a gente tem conseguido produzir assim, fazer com que eles compreendam que educação não pode ser dissociada, não pode ser separada e com isso a gente tem conseguido dar continuidade ao projeto. Mas, a sua pergunta inicial?

Sandra: Qual é a relação da qualificação com os conhecimentos da diferentes áreas do conhecimento.

DET1: O que a gente tem trabalhado e o que tem sido proposto no meio acadêmico e educacional é que se priorize a utilização da multidisciplinaridade, porque a multidisciplinaridade é um elemento que consubstancia a construção desse conhecimento. E tem se priorizado aqui no PIQ que você pode utilizar essa multidisciplunaridade em todos os módulos e em todos os níveis no Programa Integrado de Qualificação. Sendo assim se você ta ensinando, dando o módulo de cabeleireiro vai aproveitar a utilização de determinados elementos químicos para ensinar química, para ensina biologia, se você está fazendo curso da construção civil você ali tem oportunidade de apresentar os elementos matemáticos, proporção, de razão, de percentagem, se você ta dentro da informática mais ainda, mais elementos você tem que fazer, então essa interação se dá no dia a dia utilizando o elemento prático trazendo para discussão dos elementos teóricos, então há essa liga, essa aglutinação desses ensinamentos.

Sandra: Depois a gente volta nisso. Agora eu queria retomar um ponto que você falou a pouco, da questão do financiamento do programa. Como a gente no início tratou da questão de qual é o papel do poder público e aqui vou emendar, na garantia das políticas de educação, como que você vê isso hoje, porque a gente sabe que não há financiamento para a qualificação, ou há financiamento restrito, que não dá conta, seja pelo FAT ou qualquer outra via, como vocês administram isso, do ponto de vista de manter a política pública. Fala um pouco sobre $[\ldots]$

DET1: Isso. Um dos grandes problemas que a gente tem, na verdade existem recursos que poderiam ser utilizados dentro dessa perspectiva. O que ocorre é que infelizmente as decisões de Estado são muito demoradas e passíveis de muita discussão e às vezes não se leva em conta as necessidades mais reais. E só pra você ter idéia hoje, programas pra juventude só em nível de governo federal tem mais de cinqüenta programas de juventude, de diferentes secretarias, de diferentes ministérios. Se ele fosse canalizado para um programa único tipo esse PIQ, que pega a sua integralidade de formação, aí seria uma coisa bem diferente. Mas o que ocorre com esses programas é que em não tendo matricialidade, são feitos retalhadamente, não há uma complementação, então o aluno, o cidadão, não consegue fazer o aproveitamento de um curso que porventura tenha feito com o PNQ, um curso com o PROJOVEM, ou um curso que ele tenha feito lá na secretaria de inclusão, etc. Então, se esses cursos fossem canalizados para um processo de matricialidade com certeza nós reduziríamos bastante a dificuldade que nós temos com esse financiamento. Existe uma legislação, que agora deverá modificar substancialmente, o FUNDEB, mas com o FUNDEF era aquela dificuldade que eu disse, que é ensino fundamental e se for curso de pedreiro não cabe nesse fundamental, conseqüentemente seria glosado. Com essa nova modalidade, o FUNDEB já dá 
um direcionamento, já abre essa possibilidade, já fala do ensino agregado, ensino profissionalizante ou propedêutico, então já há uma possibilidade...

Sandra: O FUNDEB abre essa possibilidade?

DET1: Já abre essa possibilidade no que pese coloque apenas dentro do ensino médio, mas caberia a sociedade buscar com que isso fosse estendido também para o ensino fundamental. Mas o FUNDEB já recepciona um pouco isso. Agora, para os municípios teria essa dificuldade, porque se ele é pra esse antigo ensino médio, vai estar concentrado nos Estados e os Estados, infelizmente, ainda tem uma máquina que não consegue perceber isso com bastante visibilidade, exemplo é assim dos cursos aqui do Estado do ensino de jovens e adultos. Nós temos notícia de que pelo menos quatro escolas já foram fechadas. Nós tivemos oportunidade de ter uma reunião com o pessoal do estado onde propúnhamos uma parceria do município com o estado para oferecer o que a gente chama de PIQ III, pra ele seria o ensino médio e eles ficaram admirados porque nós dissemos que temos mais de setecentos alunos em fila de espera para entrar em nossos cursos e eles dizem que tem mais de mil e setecentas vagas, e escolas estão sendo fechadas porque não são procuradas. Isso é uma exemplificação, comparativamente, do que acontece com as propostas pedagógicas. Então enquanto o município está sobrecarregado, não tem como absorver esses alunos, mais de 700 alunos em fila de espera, o estado tem vagas em grande quantidade. Então a modalidade como é oferecida. Essa questão de financiamento ela pode ser resolvida, aqui em Santo André possivelmente nós vamos conseguir resolver, um pouco, agora, com parcerias do que seria o PMQ, o Plano Municipal de Qualificação, que é feito com o Ministério do Trabalho e que oferece a possibilidade do ensino profissionalizante com pelo menos duzentas horas, e o nosso pensamento é articular isso com o nosso ensino propedêutico, fazer essa aglutinação e somente assim nós poderíamos oferecer sem grandes problemas o chamado PIQ III, esse é um desenho que estamos fazendo e que possivelmente dará resultado.

Sandra: Pegando a questão da qualificação, vamos voltar a ela, qual é a idéia de qualificação que o PIQ tem, qual é a concepção, como ele trabalho com os itinerários, como são construídos os perfis profissionais e como isso se articula com a economia local, regional e até nacional?

DET1: Em primeiro lugar a gente reafirma que não é o problema da formação profissional que vai gerar emprego, mas a gente também precisa ter um certo cuidado, no que a gente possa oferecer para a comunidade, para a sociedade e de certa maneira, se não tivermos esse cuidado, nós criaríamos uma falsa expectativa, tanto é assim que o caso mais emblemático que nós temos é aquela questão dos cursos de telemarketing, onde o município oferecia, as centrais sindicais ofereciam, as igrejas, ofereciam, as empresas de telemarketing ofereciam, todo mundo oferecia esses cursos de telemarketing. Quando nós fomos fazer um acompanhamento mais técnico desse processo, nós vimos que houve um decréscimo da faixa salarial dos trabalhadores do segmento de telemarketing, porque como foi oferecido uma quantidade grande de trabalhadores, conseqüentemente reduziu-se a quantidade de salário que se pagava a esses trabalhadores. Então Santo André compreendeu que se mantivesse oferecendo esse curso de telemarketing, estaríamos contribuindo para a precarização do mercado de trabalho, fora que estaríamos criando falsas expectativas para os trabalhadores. Nós sabemos que o índice de desemprego por desalento, que foram aquelas pessoas que foram procurar trabalho várias vezes e não encontraram, desistiram de procurar, dentro da composição do índice de desemprego é um dos mais significativos, então as pessoas perdem a sua perspectiva de vida, já se sentem completamente incompetentes para buscar um trabalho. 
Então o que a gente faz, como normativa fazemos, é de que possamos verificar todas as variáveis que compõem a possibilidade do emprego. Então, qual é o tipo de curso que as pessoas mais buscam? Cabeleireiro? Tem uma pontuação. O que é que as empresas mais buscam? A gente vai nos arquivos da Central de Trabalho e Renda, parceria que a gente tem, e aí vai dizer o que as empresas tem mais buscado a esse tipo de profissional. Qual é a tendência de crescimento do segmento em Santo André, com dados, avaliação. Em Santo André, com o incremento do pólo petroquímico, quase que vai triplicar a demanda por mãode-obra, num primeiro momento da construção civil e num segundo momento do setor plástico. Então o que nós pensamos, o que a gente já procura fazer, é direcionar os cursos pra esse segmento que está em tendência de crescimento. Então a gente verifica o setor da indústria, do comércio e do serviço, vê em quais segmentos há uma tendência de crescimento com aporte de recursos, investimentos, etc, vimos também a tendência de consumo de outros tipos de serviço, artesanato, reciclagem, etc, todos esses elementos são elementos que constroem, variáveis que constroem a definição dos cursos que vão ser oferecidos.

Sandra: Então o departamento define os cursos.

DET1: O Departamento junto com o Observatório, consulta os segmentos envolvidos, o trabalhador: qual é o curso que o trabalhador quer, esse, qual é o trabalhador que a indústria quer, esse, qual é a tendência de crescimento do setor, esse, então todas essas variáveis conjuntamente constitui a definição que o departamento prioriza para oferecer cursos. Se o setor plástico vai crescer e o setor de hotelaria vai reduzir, a gente vai priorizar a partir de agora oferecer cursos do setor plástico e não oferecer o de hotelaria. Então isso é o que se constitui na definição dos cursos.

Sandra: E os itinerários?

DET1: Os itinerários, eles são construídos, na verdade eles são adaptados, do CBO, das características do profissional da CBO. Então se a gente vai dar um módulo do segmento de hotelaria, um módulo de garçom, qual é as exigências de conhecimento que existe para o garçom. A gente pega na $\mathrm{CBO}$ vai ser necessário que ele saiba ter uma maneira de conversar com o cliente, etc, então a gente vai oferecer um módulo que propicie a ele conhecer essa maneira de abordar, etc. É preciso ele saber o tipo de bebida, então nós vamos oferecer um módulo que ele possa conhecer esse tipo de bebida. Então nós vamos estar fazendo a formação dentro daquele contexto que é exigido na $\mathrm{CBO}$, porque a $\mathrm{CBO}$ é uma padronização nacional e se você forma tendo como diretriz essa $\mathrm{CBO}$, pouca dificuldade...

Sandra: Então vocês não trabalham nem com aquela consulta das vinte áreas do ensino técnico que o Ministério, ainda na gestão anterior criou.

DET1: Não, na verdade essa construção se dá se baseando na $\mathrm{CBO}$, exatamente porque ela é um elemento determinante já que a proposta do PIQ é também de propiciar, de criar condições para que essas pessoas ao saírem tenham a oportunidade de conseguir um emprego. Não é promessa, mas que possivelmente ele terá maior possibilidade, dos egressos que a gente avalia, a gente vê que boa parte desses egressos, às vezes temos até dificuldade porque antes de ele terminar o curso ele consegue emprego por conta de ter feito alguns módulos, então boa parte desses egressos consegue essa colocação porque o curso está formatado de maneira que atenda aquela necessidade que está definida lá na CBO. Enquanto que você utilizar do ponto de vista de outros parâmetros, pode estar deslocado da sociedade, então teria que 
desconsiderar algumas variáveis importantes, como essas que a gente citou anteriormente, verificar tendência de crescimento da região, do mercado, etc.

Sandra: E qual que é a relação do PIQ com as políticas de geração de trabalho e renda, de outras secretarias, mais a de desenvolvimento econômico?

DET1: A proposta do PIQ, vamos dizer, ela se encerra na conclusão do curso no PIQ III, então o aluno concluiu o curso, ele passa, ele é responsabilidade do estado, do governo municipal, mas não é mais responsabilidade da Educação. Ele concluiu aqui nós encaminhamos o banco de dados desses alunos para a Central de Trabalho e Renda, o Centro Público de Emprego, Trabalho e Renda. Então essa relação nós passamos toda pra ele, formação, tudo direitinho, com os dados cadastrais, e a partir daí eles tocam. Seja na perspectiva de construção de trabalho alternativos, cooperativas, como trabalho autônomo, etc, ou mesmo a alocação e o encaminhamento deles para aquelas empresas que estejam recrutando esse profissional. Mas a partir de 2008, inclusive, nós já vimos e deveremos implementar, alguns módulos que propiciem ao aluno conhecer também essa questão da auto gestão, essa questão do trabalho autônomo, etc.

Sandra: Na perspectiva da economia solidária?

DET1: Também na perspectiva da economia solidária. Bem assim também eles nos encaminham alunos, trabalhadores que se inscreveram lá que precisariam concluir o ensino fundamental, etc, eles também nos encaminham.

Sandra: O Departamento dá alguma orientação explícita com relação ao que hoje é uma orientação que não é consenso e é polêmica, do ensino pautado em competências, principalmente na área da qualificação ou não?

DET1: O pensamento do departamento é de que a gente possa aproveitar o saber já construído pelo trabalhador, pela sua história. Isso a gente também, deveremos estar iniciando a implementação disso, a partir de 2008. A dificuldade que nós tínhamos era a questão da certificação, mas pelo menos de fundamental, do primeiro ciclo do ensino básico, a gente já começará a fazer a certificação do conhecimento desses trabalhadores, desses jovens, mesmo porque, se você tem, um cidadão que está inscrito lá, ele está fazendo curso de elétrica, mas ele é um excelente eletricista, a gente vai lá e faz uma aferição até que nível ele estaria habilitado para ser certificado naquela atividade que ele exerce.

Sandra: A certificação não necessariamente está aliada a idéia da competência. A pergunta é essa, se vocês trabalham nessa perspectiva do ensino por competências, ou isso é algo que não está discutido ainda plenamente no departamento.

DET1: Não, não está discutido.

Sandra: Porque a certificação ela pode ser de saberes, de experiências, de conhecimentos, ou até de competências, se é essa a concepção. A minha pergunte é nesse sentido. Isso é uma coisa que está clara e definida ou não.

DET1: Não, não está definido. A gente tem alguns trabalhos que tem feito, está fazendo alguns estudos, por conta do convênio com o Ministério do Trabalho com a UNICAMP, e que 
está envolvido Diadema, Santo André, Osasco e Guarulhos. Todos esses aspectos a gente vai estar discutindo e amadurecendo.

Sandra: Voltando na questão dos jovens, eu queria te fazer duas questões pra você discorrer sobre elas. Primeiro, na formatação inicial do Programa, nos seus objetivos, constava a questão da bolsa. Porque um dos objetivos do Programa era que o trabalho com jovens visasse a não inserção precária dele no mercado de trabalho. Então o Programa tinha uma intenção de retê-lo ainda fora, não tirar os trabalhadores mais velhos, vamos dizer assim, dos seus postos. Essa questão da bolsa como que ela aconteceu efetivamente ou não e o outro dado é que durante esses anos, inclusive em peguei dados no Observatório, o PIQ não atende só os jovens, aliás, a proporção maior é de pessoas acima de vinte e cinco, então eu queria que você falasse disso.

DET1: Bom, então, um dos eixos, como disse, é esse terceiro eixo, o da bolsa da monitoria. Ele aconteceu, foram experimentos extremamente interessantes, em que os jovens que faziam principalmente os cursos de informática tiveram a oportunidade de serem monitores dos cursos de inclusão digital, lá nos seus bairros. Então eles foram contratados na razão de um salário mínimo por mês para fazerem essa atividade. E aí aconteceu os fenômenos que vieram a colaborar com a compreensão que nós temos, da necessidade dessa monitoria, desse estágio.

Sandra: Deixa só eu te interromper pra você já falar, isso foi uma experiência, uma ou duas, ou foi algo que se massificou para o Programa? Quais foram as dificuldades para que isso acontecesse?

DET1: A dificuldade que nós tivemos foi a dificuldade do ponto de vista do recurso. Não teria como justificar isso perante o Tribunal de Contas, porque aquilo estava sendo pago como uma bolsa. Nós conseguimos implementar uma monitoria dessa natureza por meio de parceiros. $\mathrm{E}$ aí é difícil você encontrar parceiros suficientes para suprir quase oito mil alunos no geral que a gente tem, então teríamos dificuldade em fazer isso. Agora começa a aparecer uma nova possibilidade com essa reformatação de PROJOVEM. Então o PROJOVEM está vindo agregar aqui em Santo André e possivelmente poderá contribuir um pouco com esse novo formato. Mas nós não conseguimos implementar na sua plenitude, sem redundância, da questão do terceiro eixo que é a bolsa. Agora, é uma experiência fundamental, como eu estava dizendo, dos lugares que aconteceram houve uma mudança substancial no modo de compreender de determinados jovens. Na periferia você vê muito essa questão da influência do tráfico, e tinha a declaração de um jovem do Jd. Santo André, por exemplo, que dizia que o sonho dele quando era criança era ser avião do tráfico, porque na verdade o avião é a pessoa que tem prestígio, que as pessoas respeitam, que namora a menina mais bonita, que veste a calça melhor, que tem dinheiro pra ir para farra, etc, então ali é o referencial das crianças e do adolescente. De repente ele começou a trabalhar nessa monitoria e conseguiu um respeito diferenciado. Era ele que ajudava a fazer os currículos dos adolescentes, ajudava a tirar uma receita de bolo para uma mãe da família que procurava ele lá no laboratório de inclusão, então conquistou um novo referencial, porque a nossa proposta é a de que ele possa ser monitor no seu local de moradia, em um dos laboratórios no seu local de moradia. Então ele poderá na construção civil, ele está contribuindo com os moradores do seu bairro, orientando como fazer um alicerce, orientando como fazer um reboco, como fazer uma construção, e assim sucessivamente em todas as suas modalidades.

Sandra: Isso PROJOVEM, e aí volto na questão, a gente tem ainda a maior parte dos usuários do programa maiores de 25 e uma faixa etária até mais avançada de 35, 30 , 40 anos em 
diante, que aí é uma perspectiva diferente que não é essa de você apontar uma perspectiva de início de construção de uma carreira, mas é outra situação. Como que o PIQ se adequou a isso? Ou não se adequou?

DET1: É você tem razão. A primeira coisa, aquilo que você apontou, o objetivo maior do PIQ era atender a juventude, no intuito de que pudesse reter um pouco esses profissionais que não estariam suficientemente preparados para conseguir reivindicar seus direitos como trabalhadores..

Sandra: E não terem usufruído de seu direito a escolaridade...

DET1: Exatamente. Então, a construção era nesse sentido, que retinha ele, prepararia ele, no sentido da cidadania e profissionalmente, e ele, se ficasse um ou dois anos fora do mercado de trabalho se preparando, quando ele fosse para o mercado de trabalho ele ia bem melhor preparado, conseqüentemente com condições de reivindicar uma melhor remuneração. E em ele ficar fora desse mercado de trabalho ele deixaria de comprimir o mercado de trabalho, que a gente sabe que não existe espaço vazio, ali no trabalho se alguém entra, alguém sai, a não ser que haja crescimento econômico. Pro nosso país ter um crescimento econômico que possa absorver a quantidade de jovens que ingressam a cada ano, muito mais que cinco milhões de jovens a cada ano, pro país atender essas necessidades ele teria que estar com uma taxa de crescimento anual de mais ou menos 10 a $11 \%$, sobre toda essa demanda por postos de trabalho. Como isso não acontece, como isso não está acontecendo, ele ficando fora desse mercado de trabalho não comprimiria o mercado de trabalho, conseqüentemente as pessoas de mais idade se manteriam, nessa escala do trabalho, isso do ponto de vista do jovem. Do ponto de vista do adulto, boa e significativa parte que procuram nossos cursos, é por dois motivos: o primeiro motivo é porque ele quer se aperfeiçoar, para se desenvolver mais na empresa, ou mesmo porque ele está correndo o risco de ser demitido, com a massa de jovens que ingressam no mercado de trabalho ele quer se aperfeiçoar mais pra se manter no emprego, ou mesmo pra aqueles que já estão desempregados e não vêem mais perspectiva de ingressar no emprego formal. Então eles procuram o segmento principalmente de serviços, como construção civil, manicure, pedicure, esses tipos de serviço pra se preparar e trabalhar como avulso, como autônomo, ou mesmo num segundo momento, na construção de uma cooperativa ou uma coisa dessa natureza. Então essa é uma parcela que está sendo atendida com uma perspectiva enquanto aquela parcela está sendo atendida com outra perspectiva, mas que o Programa se propõe a dar conta dessas duas situações.

Sandra: Estou fazendo essa pergunta, porque você sabe que eu trabalho no Programa, isso está na pesquisa também, que eu faço um estudo de caso, mas também do olhar de quem está envolvido na situação, e a gente vê salas de aula com alunos de 14 a 60 anos fazendo o mesmo curso. E eles têm perspectivas diferentes. Então, se o Programa ta preocupado com isso de alguma maneira, pra readequar, reorganizar, como que é dar qualificação pra um adolescente de 14 anos?

DET1: Isso é interessante porque às vezes você encontro no mesmo Centro três gerações diferentes, a avó que está estudando, se alfabetizando, o pai que está fazendo o curso profissionalizante e o jovem que também está fazendo o curso profissionalizante. Então na verdade você conciliar esses três estágios, é uma coisa extremamente complicada, você saber perfeitamente que a gente tem algumas dificuldades porque o adulto quando já está lá, ele já está com a cabeça clara de objetivos, o que ele quer, etc, etc, o jovem está ainda tentando descobrir melhor o que que ele quer e às vezes há um certo conflito de geração ali dentro. Mas 
isso, ao invés de ser negativo, eu pessoalmente vejo como positivo, ali se dá um processo de discussão inter gerações que em outro espaço, eu não conheço nenhum outro espaço que propicie isso naquelas mesmas condições, seja do recreio, da hora do lanche, das discussões de sala de aula, seja dos problemas que acontecem com o filho do outro, sabe que acontece com seu filho, então ele vivencia todo o problema daquela comunidade do centro profissionalizante, de uma certa maneira o centro profissionalizante se catalisa, se torna um elemento catalisador de muitos problemas que a sociedade local vive. Então a AP é procurada por uma mãe que a filha está no tráfico, que está isso, que está aquilo, ou que não quer estudar, então termina sendo um centro catalisador de todos esses problemas.

E por fim, o que acontece é a sociedade local compreender aquele centro como um espaço seu, daí que temos tão poucos problemas, já tivemos mais, problemas de depredação, de pichação, etc, nos ônibus dos próprios Centros. Então essas duas expectativas, essas duas perspectivas são atendidas sem muito choque, sem muito embate. Isso termina, essas três gerações convivendo, daí absorvendo determinados elementos que com certeza vai ser levado pra vida com mais força e com mais consciência.

Sandra: E como que o PIQ tem trabalhado, se tem trabalhado, com as etapas subseqüentes da formação dos trabalhadores, não só na qualificação, mas também na escolaridade.

DET1: Isso. O que a gente tem feito, é procurado fazer um certo acompanhamento desses alunos egressos. Ainda não temos pernas suficiente pra acompanhar todos os egressos, então a gente faz por uma amostragem mais significativa. E além de termos essa parceira com o Centro Público de Trabalho, Emprego e Renda, de encaminharmos esses jovens ou adultos para uma possível colocação no mercado de trabalho, também temos procurado fazer determinados convênios e parceiras com universidades que possam absorver esses alunos, com um preço de mensalidade, uma espécie de bolsa, que possa ajudar ele a dar continuidade. E assim nós temos experiências de pessoas que depois de adulto, no MOVA e hoje na faculdade de psicologia, fazendo pedagogia, fazendo, temos gente na universidade federal. Então o que a gente tem conseguido acompanhar é, que é uma proposta nossa de fazer esse acompanhamento, no que pese não ser uma responsabilidade da secretaria de educação, mas a gente tem procurado acompanhar mesmo para que a gente possa fazer, se for o caso, algumas correções no nosso fluxo dentro...

Sandra: Eaí eu queria entrar em um outro campo, que é o da gestão mesmo. Qual que é o nível de participação ou de interferência que os alunos, as equipes, dos centros públicos, os professores, tem no programa?

DET1: O Departamento priorizou para que pudéssemos contribuir para que os alunos tivessem sua própria organização no local de estudo. Já tem os Conselhos, mas entendemos que os Conselhos de Escola, ele cumpre um determinado papel, mas precisaríamos de um ente que tivesse uma maior agilidade desses contatos, desse retorno. Então, foi propiciado, sugerido, que os alunos fizessem seus grêmios. E os grêmios, onde eles começaram a funcionar tem dado alguns resultados. Tem procurado fazer algumas gestões políticas, tem procurado o departamento, a secretaria, mesmo o prefeito pra fazer sugestão, tem procurado as diretoras dos Centros pra fazer sugestão, e também criamos o que a gente denominou de canal aberto, que é uma urna onde os alunos colocam as suas preocupações e as suas reivindicações, esses documentos são lidos diretamente pelo Departamento que faz um levantamento, verifica quais são as reivindicações, e dá um retorno para os alunos dizendo o que é que foi feito. Isso também é uma certa contribuição dos alunos para que a dinâmica não fique também muito cristalizada, vamos dizer assim. 
Sandra: E os professores.

DET1: Os professores, a proposta do PIQ é que tenha os estágios de discussão, que seria o núcleo pedagógico, que teria o papel de discutir todas as questões pedagógicas da escola, mais especificamente daquele centro, onde ali se discutisse essas questões e se chegasse a um consenso, temos também o fórum que deveria ter uma maior amplitude, deveria atender todos os centros. O fórum pedagógico tem o intuito de atender todos os centros e se passar as experiências de um centro para outro o que é comum em todos os centros e o que foi abordado em cada um desses centros, essa é a função do fórum pedagógico.

Sandra: E esse fórum seria uma reunião de todos os professores.

DET1: Isso.

Sandra: E o DET trabalha com entidades conveniadas. E a princípio o que se preconiza é que essas entidades tenham já experiência em qualificação e educação de alguma maneira. Qual que é o papel delas?

DET1: Bom, a primeira coisa do papel dessas entidades é o aumento desse fluxo de interação Estado, sociedade organizada, sociedade civil etc. Então essas entidades também compreendem esse papel de contribuir com o município nessa discussão mais ampla. E aliado a isso, a gente exige também essa experiência, esse conhecimento de determinados segmentos da formação profissional, que aí eles vem contribuir conosco e tem um fator interessante, aí, o fator é de que como os nossos cursos estão formatados com uma certa possibilidade de mobilidade, ou seja, esse semestre eu posso ter o curso de pedreiro, no próximo semestre não posso oferecer curso de pedreiro porque não tem demanda, porque nenhuma pessoa procurou. O acesso ao emprego público só se dá por concurso, então se você contrata profissionais para dar curso de pedreiro, e no próximo semestre não tem mais esse curso de pedreiro, taí um profissional contratado por concurso público sem ter onde ter aplicabilidade desse profissional. Nós temos casos específicos, nós temos pessoas aqui que é instrutora de datilografia, nem existe nem máquina de datilografia aqui mais, não há uma maneira de tirar ela para outro lugar, ela só poderia passar por outro lugar se fosse através de concurso público. E assim sucessivamente, tantos monitores que a gente tem contratado que se você mudar a modalidade, mudar o tipo do módulo, você estaria com esses profissionais sem ter onde colocar. E as entidades elas também cumprem um pouco esse papel de nos ajudar nessa mobilidade de oferta dos cursos.

Sandra: Como que é feita a avaliação do Programa, quem avalia, os alunos avaliam, as equipes dos Centros, como é feita a avaliação do Programa?

DET1: Nossa proposta de avaliação do programa é a proposta tradicional, em certo termo, a definição tradicional de monitoramento e avaliação. Ou seja, esse monitoramento se daria através do observatório. O observatório faria a constatação dos três elementos: eficiência, da efetividade e da eficácia, esses três elementos que avaliaríamos se trouxe esses resultados. Se ele não trouxe, ele vai ser retirado, modificado, porque você tem a avaliação ex ante, ou seja, a avaliação do que você deveria propor de curso, você tem a avaliação [...] que é a avaliação durante o processo com modificação, você avalia no processo, se você acha que o Programa deveria continuar, mas deveria modificar uma ou outra variável, você modifica, a avaliação [...], e avaliação ex post que é a avaliação depois de implementado, depois de encerrado etc o 
acompanhamento dos evadidos. Então todos esses são variáveis a ser consideradas na avaliação geral. Então você tem a avaliação específica dos Centros, avaliação específica dos núcleos pedagógicos, e a avaliação dos alunos, todas essas formam o conjunto que é a avaliação do programa.

Sandra: Tá, e é o Observatório que realiza as avaliações.

DET1: É o Observatório.

Sandra: E ele faz isso como: com consulta, com...

DET1: Ele faz com pesquisa, dos egressos, ele faz com pesquisa dos egressos, ou visitando as casa, ou contato telefônico, ou dependendo daquele momento que ele faz, essa é uma avaliação, de quantos que saíram daqui daquele segmento que foram empregados, que gerou alternativas de emprego, faz isso através de formulário, os profissionais do centro, professores, etc, e assim sucessivamente.

Sandra: Eu sei que você tem horário, então vou fazer a última pergunta, na última vou juntar três. Pela especificidade do PIQ, ele busca se diferenciar como você mesmo falou várias vezes da escola que a gente tem hoje naturalmente, entre aspas, colocada, uma escola que como você mesmo disse não responde às expectativas, às demandas ou às necessidades. Isso quer dizer que você tem que ter um corpo docente que atenda a isso. Como é pensado isso no sentido da formação, o que o departamento propõe, o que ele cobra, o que ele tem feito?

DET1: O pensamento do Departamento da preparação dos profissionais pra essa modalidade ele é bastante diferenciado, porque tivemos a sorte de termos profissionais aqui com a cabeça completamente aberta para as mudanças e a compreensão do que seria o programa. Mas essencialmente, a maioria dos profissionais são formados pra trabalhar com ensino infantil. Então, num primeiro momento isso poderia ter parecido uma dificuldade, mas em função da abertura desses profissionais nós conseguimos oferecer algumas formações, incentivar algumas formações que contribuísse mais para abrir a cabeça com essa possibilidade. Então fizemos alguns cursos com a escola de economia da UNICAMP, com a Universidade Federal, com algumas assessorias que nós trouxemos pra discutir essas questões do mundo do trabalho, então se deu a formação de um novo patamar desses profissionais, que conseguem compreender essa forma de educação.

Sandra: Você quer fazer mais algum comentário?

DET1: Se você quiser você manda por e-mail mais alguma coisa que eu te respondo.

Sandra: Está bem, ok.

DET1: Pode mandar.

Sandra. Está bem, obrigada. 
$28 / 12 / 2007$

\section{ENTREVISTA - DET2}

Sandra: Por favor se apresente, fala da sua formação, da sua trajetória, como você chegou até aqui, qual a sua função aqui.

DET2: Sou formado em psicologia desde 92 ou 93, fui da direção do sindicato dos psicólogos, da federação dos psicólogos, depois fui pro Conselho Regional de Psicologia, fui membro do Conselho Nacional da Saúde, da mesa nacional do SUS, depois larguei a saúde e me direcionei mais para a educação. Na faculdade em psicologia o meu direcionamento foi mais para a área de educação. Depois na atividade profissional fui mais para a área da saúde. Mas hoje não sou mais psicólogo, cancelei meu registro e hoje só trabalho na educação.

Sandra: Você é assistente de direção. Fala um pouco qual é a sua função.

DET2: A minha função deveria assistir o diretor, em todas as suas ações políticas, profissionais, estratégias para estar atingindo os objetivos planejados pela secretaria.

Sandra: Queria que primeiro você me falasse qual é a sua visão de educação popular.

DET2: A educação popular é aquela que é dada para aqueles que não tiveram condições de estar seguindo a educação formal. É uma forma de se dar condições, levar os direitos àqueles que não tiveram condições.

Sandra: E qual é o papel do poder público?

DET2: Quanto...

Sandra: Quanto a educação popular.

DET2: O poder público tem que fomentar, acho que não só o poder público como as organizações deveriam estar vendo isso. Hoje aqui na Prefeitura de Santo André o poder público fomenta isso, isso não quer dizer que a educação vai ser mantida em outras administrações, mas pelas característica hoje da prefeitura ser uma prefeitura petista, então ela incentiva esse tipo de linha com o MOVA, hoje eu vejo o MOVA como uma educação popular, aquela que não é formal. Se a gente pegar municípios que não tem uma linha nesse sentido, por exemplo São Caetano, não existe nenhum fomento a esse tipo de coisa.

Sandra: Estou fazendo esta pergunta pelo fato do PIQ ser um programa justamente voltada para as pessoas que não tiveram essa oportunidade de continuar a escolaridade, nesse sentido, como ele se insere no campo da EJA, a minha pergunta vai nessa direção, então qual é a relação do PIQ com a ed. Popular e qual é o papel do poder público nesse sentido. E aí eu queria que você falasse um pouco mais, do poder público municipal, estadual, do federal, como que você vê isso?

DET2: Vamos pegar o estadual... 
Sandra: Diretamente relacionado a EJA.

DET2: Ta, vamos pegar o estadual. Hoje, se a gente pegar pelas informações, não tenho a experiência prática do Estado, mas pelas informações sempre deixa a desejar. Aquilo que eles deveriam estar fazendo, aqui no estado de São Paulo, acaba não contribuindo, não seguindo, não dando condições para o adulto prosseguir nos seus estudos. No município, vamos pegar aqui o caso de Santo André, desde o início, eu entrei aqui em 99, desde que eu entrei sempre se atuou nesse campo, o próprio Departamento de Educação do Trabalhador, quando o Celso cria, era para estar pegando esse eixo, para estar fomentando isso, mesmo que com posições, entre aspas, que são questionadas pelo Tribunal de Contas. Hoje a educação profissional aliada ao aumento de escolaridade para o adulto, em muitos municípios não se faz porque o recurso do município com educação não pode ser gasto com educação profissional, só para você ter uma idéia as contas do município de Santo André estão sendo glosados desde 98. Então você vê que aqui mesmo sabendo disso, o pessoal vai nessa linha de estar fomentando, de entender que a qualificação profissional ela é um fator de identificação do adulto pra continuar no estudo, pra resgatar esse momento da educação que foi interrompido.

Sandra. Já que você falou das contas vou entrar em uma outra questão que é a questão do financiamento do programa. Como vocês resolvem esse problema?

Milton: Como assim?

Sandra: Hoje o PIQ é uma política pública, do poder público municipal. Como ele é financiado?

DET2: Hoje nós utilizamos recursos que é destinado a educação. A gente tem a parte profissionalizante que se justifica como se fosse uma estratégia para estar buscando esse adulto, pra ser um facilitador no aprendizado desse adulto.

Sandra: É porque a gente sabe hoje que não existe uma linha direta de financiamento pra qualificação que não seja via aquelas verbas do FAT, que vem de tempos em tempos, que não são contínuas, então vocês usam recurso da educação.

DET2: Isso.

Sandra: Então que queria que você agora definisse o que é o PIQ.

DET2: O PIQ é um programa de aumento de escolaridade vinculado com qualificação profissional. Vou colocar o que eu acho do PIQ. O PIQ hoje, a qualificação profissional a gente coloca como o fator que vai propiciar pro trabalhador ou pro adulto o seu emprego. Isso é uma ilusão, a gente sabe que isso vai acabar não ocorrendo. A importância dessa qualificação profissional, dentro desse programa de elevação de escolaridade, é mais na identificação e um facilitador pra aprendizagem. É óbvio que o trabalhador vai ter um instrumento a mais pra poder disputar vaga de mercado, criar um serviço, um trabalho. O PIQ hoje é isso, o direcionamento pra continuidade de estudo enquanto direito, utilizando de estratégias pra que o trabalhador fique em sala de aula, dê continuidade, esse valor que ele não tem, esse direito que ele não se vê como direito. 
Sandra: E o que fundamentou a criação do PIQ. De quais fontes ele bebe?

DET2: A gente veio pela construção. Em 98, 99 quando eu entrei tinha só os cursos de qualificação profissional e alguns cursinhos de suplência, que atrelavam a suplência profissionalizante. E aí a gente foi num crescente, batendo, aprofundando, e em 2003 se não me engano, 2003, 2002, frente a tudo aquilo que a gente já queria tentar unir, o aumento de escolaridade com essa qualificação, isso se deu, já é uma bandeira que a gente vem construindo há um bom tempo.

Sandra: Ele não se pauta em nenhuma outra experiência?

DET2: Olha, pelo menos eu não conheço, mais a percepção aqui, eu não conheço algo que estaria se baseando não. Teve algumas experiências daquele programa da $\mathrm{CNM}$, o Integrar, mas na realidade as atividades. As coisas foram acontecendo e a gente vendo o que era o facilitador desse processo pro trabalhador.

Sandra: Como você definiria os objetivos do PIQ?

DET2: É um curso que dá as condições pro adulto aumentar sua escolaridade e dá possibilidade de ele ter noções da profissionalização, porque hoje não dá pra chamar o curso de profissionalizante, que o cara vai sair com todos os conteúdos, as técnicas para estar enfrentando uma profissão aí fora.

Sandra: Então, com relação a questão da qualificação hoje, você não definiria que há realmente uma qualificação profissional?

DET2: Hoje eu estou chegando a essa conclusão. Não porque não se tem o tempo, certo, mesmo o programa sendo, teria um dos objetivos era dar a base e dar condições para que o trabalhador fosse buscar fora a continuidade desse aprimoramento, mas a gente sabe que não funciona desse jeito. A gente não conseguiu atingir um dos objetivos. No início lá atrás, a gente lembra que uma das coisas que a gente acreditou bastante era dar condições para que o aluno que passasse por aqui, ele tivesse instrumentos para aprofundar suas questões e hoje eu acho que a gente não atinge esse objetivo. Hoje eu acho que todo o programa deixa muito a desejar nesse sentido.

Sandra: Você está falando de qualificação, de continuidade. Então vou te fazer duas perguntas: primeiro, como que, se o Programa dá condições, como ele articula ou se não articula a continuidade de estudos do aluno quando ele sai e a idéia do itinerário formativo, eu queria que você falasse, porque na origem do Programa se fala do itinerário formativo, então eu gostaria que você falasse qual é a concepção de itinerário formativo, como ela se coloca hoje ou se ela não se coloca.

DET2: A intenção do itinerário no PIQ era a de estar dando condições, dando conteúdos, dando conhecimento, onde o aluno ia construindo seu conhecimento frente a uma profissão. Então através de módulos o aluno ia passando, construindo aquilo que tivesse na intenção dele, na vontade dele. Hoje nós não conseguimos aplicar aquilo que a gente pensava, acho que tem um itinerário, mas um itinerário mais direcionado da gente, de conteúdos, de forma que a coordenação, o corpo pedagógico acha. Acho que nesse sentido também deixou a desejar em muitos sentidos, agora... 
Sandra: Aquela idéia de itinerário formativo você acha que não está mais?

DET2: Não aquilo que a gente idealizou lá atrás. Acho que também não vingou. Agora, a continuidade é até o PIQ II e o PIQ III que é o ensino médio. Acho que é o que a gente pode chegar. É o que a gente consegue chegar no máximo.

Sandra: A articulação com outras instituições não existiu?

DET2: Não tem, todas as vezes que a gente vai falar com outras instituições, com o próprio Estado, a gente fez esse movimento de conversar com a Paula Souza, com o pessoal, não há vontade política para que isso ocorra. Hoje infelizmente governos diferentes, com perspectivas diferentes, não sentam para poder unir esforços. É triste, mas é realidade.

Sandra: Como que você vê esse programa, essa política pública, dentro do plano de governo municipal? Qual é a importância que ela tem?

DET2: Eu acho que é a base. Um plano de governo de uma prefeitura popular e democrática, uma prefeitura petista, tem que ter primeiro o viés da educação popular, segundo a questão da educação do trabalhador, então é a base, não vejo um plano de governo que não pense isso. Aí você poderia me perguntar: mas tem algumas prefeituras que não conseguem atingir isso. Pelo que eu percebo nas discussões que a gente tem com outras prefeituras o medo maior é quanto ao financiamento disso, quando eles conseguem recursos eles fazem algumas coisas, não como aqui em Santo André. Santo André pega um filão grande para poder fazer esse trabalho. Mas mesmo nas outras prefeituras eles tentam de alguma forma tocar alguns programas nesse sentido. Então acho que é a base, é um dos pontos chave de um plano de governo, de uma prefeitura, de um partido dos trabalhadores.

Sandra: Você falou da questão de como os conteúdos da profissionalização você vê hoje muito mais como relacionados aos conteúdos das outras áreas de conhecimento, no sentido de estimular o trabalhador a estudar, aumentar seus conhecimentos. Como que você vê essa relação.

\section{DET2: Não entendi.}

Sandra: Você falou anteriormente que você vê a qualificação muito mais como os conteúdos que servem para estimular o trabalhador a relacionar esses conhecimentos com outras áreas do conhecimento. Então eu queria que você focasse nessa questão: como que você vê hoje, que avaliação que você tem da articulação da questão da qualificação com a elevação da escolaridade.

DET2: Eu acho que esse é o princípio. Se tirar a educação profissionalizante, morre praticamente o programa em si. Eu, aí é só impressão, não tem nenhum dado, só impressões e avaliações superficiais de alguns dados, quando no início do processo a gente atrelava aumento de escolaridade com qualificação profissional, o índice de evasão era menor que a média. Hoje, se a gente for pegar, esse ano que passou, eu acho que nós deixamos muito a desejar na qualificação profissional. Por mais que a gente tenha investido, houve uma organização da própria equipe de buscar recursos materiais pra poder implementar a qualificação profissional. Então, a minha avaliação, houve um alto índice de evasão no programa, atingindo os níveis que hoje a EJA tem no Brasil. Antes não tinha esses índices. Eu acho que se for feita a qualificação profissional onde o trabalhador perceba a importância 
disso enquanto conhecimento e instrumento pra enfrentar a vida do dia a dia, essa vontade do trabalhador, do adulto estudar aumenta, permanece, é uma coisa que estimula ele a ficar em sala de aula e dar continuidade aos estudos. Eu acho que isso é fundamental. Se a gente pegar o SEJA, desde que eu entrei aqui na prefeitura o SEJA sempre foi um programa que tinha um alto índice de evasão, uma coisa com baixa qualidade, não estou falando dos profissionais, mas se eu pegar os índices de evasão e o programa o próprio adulto está falando, é um programa que não funciona muito bem pra gente e quando a gente pegava os dados da qualificação profissional pensava, o que ocorre nisso? O trabalhador também faz um curso, faz outro, mas ele percebe que ajuda mas não resolve o problema e acho que a grande sacada foi atrelar essas duas coisas e colocar em um programa.

Sandra: E você acha que o Programa dá conta de relacionar essas duas áreas?

DET2: Deveria dar.

Sandra: Mas se não tem uma avaliação como você consegue fazer isso?

DET2: Hoje eu saio desse momento com dúvidas no Programa. Acho que a qualidade... você sabe, conhece...

Sandra: E você atribui a que?

DET2: Acho que misturou muito vontades de grupos, falta de interesse dos próprios profissionais tanto da prefeitura como da equipe diretiva, acho que misturou muito isso daí.

Sandra: Voltando a questão do itinerário, mas como você disse que não vê mais a qualificação..., eu ia te perguntar porque em outras instituições se trabalha muito primeiro com a definição do perfil profissional, vai estudar as famílias, carreiras, aí constrói itinerários, cursos, módulos. Esse movimento existe aqui, não?

DET2: Muito pouco. Tentou-se, um tempo atrás se fez esse movimento, mas se perdeu. Acho que a direção, a coordenação, se perdeu em ações mais pontuais e deixou isso de lado. Eu vou dar o exemplo de algumas coisas. Eu em 1979 entrei no SENAI. Fiz o SENAI em um ano e meio mecânica geral e depois mais um ano ferramentaria. Mesmo depois de todo esse tempo quando fui pra uma empresa trabalhar, eu trabalhava na Ford. Mesmo com todos os conteúdos que eu aprendi, aquela bagagem que foi bastante, a gente era suscitado a coisas que a gente não sabia. Então hoje sempre a qualificação profissional, por mais que você pegue as técnicas, veja com condições instrumentos, maquinários, você sempre fica atrás das inovações. Vamos pegar agora e trazer pra cá, hoje, você sabe que por mais que a prefeitura invista os recursos em equipamentos, é baixo. Não é um SENAI da vida que tem um recurso bom em investimento. Então eu não posso achar que nós estamos fazendo uma qualificação de alto nível. Acho que a gente dá é noções gerais. E deveríamos orientar aos alunos a estar procurando outras instituições que têm condições de aprofundar isso e melhorar a qualidade. É claro sempre sabendo que ele vai estar sempre atrás dessas novas tecnologias.

Sandra: Ainda dentro do itinerário a outra questão que vou fazer na verdade você acabou respondendo sem responder, que hoje tem uma discussão dentro da qualificação, que é a questão das competências. Eu queria saber se vocês aqui trabalham com essa idéia, com essa noção ou idéia de competência, ou não, se optou por não fazer? 
DET2: Acho que você sabe, você vivencia isso. Não se aprofundou isso. Algumas pessoas levam essa discussão, outras levam sem saber. Hoje, na minha avaliação, precisaria dar uma brecada nos programas, uma redefinição na equipe, discutir os princípios e os pressupostos disso, saber o que é, saber se vai ser utilizada as competências ou não, ou ir por outro caminho, hoje estou meio cético com a coisa, você me pegou em um dia...

Sandra: Vamos mudar um pouco o campo das questões. Ainda relacionado, mas já pensando na questão da articulação com outras políticas. Como que você vê, se há, uma articulação com políticas de geração de trabalho e renda.

DET2: Se tenta fazer muito isso. Desde estruturar planejamento, discutir concepções.

Sandra: Mas efetivamente, há uma ação com as outras secretarias?

DET2: Há e grande. Hoje a secretaria que a gente tem mais afinidade é a secretaria de desenvolvimento econômico.

Sandra: Quais são as ações concretas que estão sendo encaminhadas?

DET2: Quando se dá capacitação, mesmo sendo uma capacitação básica, a gente encaminha para o DGTR, para a Central de Trabalho e Renda que hoje é o Centro Público de Emprego, Trabalho e Renda, então há sempre trocas de informações, encaminhamentos, muitas vezes acho que as condições que se dão do mercado, da própria situação concreta é que dificulta que se faça algo a mais. As discussões sempre foram muito boas, as intenções foram boas, mas se perdeu nas condições, em buscar condições. Então sempre se teve a intenção de dar cursos, de dar formação, de se planejar, o próprio PNQ é uma articulação conjunto com o DGTR...

Sandra: O PNQ, não o PIQ.

DET2: Tanto o PNQ...

Sandra: Ah, o nacional não o municipal...

DET2: É o PIQ também, a gente discute os cursos em si, qual é a necessidade, estamos sempre solicitando para que levem discussões, palestras, orientação quanto ao cooperativismo, a economia solidária. Tivemos há um tempo atrás várias palestras que eles deram. Quanto a isso acho...

Sandra: Essas são as ações mais próximas dos alunos.

DET2: Tem o programa Mais Igual também. O Família Andreense. Tenta articular várias políticas, então aí o DGTR, a assistência social, se discutem estratégias para se tirar as pessoas da situação em que está. Hoje nos nossos programas a prioridade é para as pessoas que vêm dessas áreas, onde estão instalados esses programas integrados, é para que elas tenham prioridade em cursos, em ações da prefeitura. Isso numa concepção de que se concentrar várias ações naquela família, naquelas pessoas, eles vão ter condição de sair da situação em que se encontram. Essa é a estratégia e os dados mostram que tem dado certo. Isso é uma política que o Celso fez lá em 1997, originou em 1997. 
Sandra: Voltando mais ao PIQ. O PIQ como você disse, tem mostrado índices altos de evasão. E além da evasão, para a gente que está na escola, a gente vê um problema sério que não de evasão, mas que é de freqüência. E que isso não aparece em dados. Como que você considera que o Programa lida com isso? Que alternativas propõe?

DET2: Na realidade, hoje a Secretaria não tem essa discussão, acho que nós perdemos. Acho que a coordenação do Programa não conseguiu lidar com isso. Não conseguiu ver esse eixo com as equipes locais, com a direção, AP's locais para poder ver quais são as estratégias para tentar reverter essa situação. Então hoje não se discute isso, se deixa mais para a equipe local definir estratégias.

Sandra: Então não há uma orientação da direção do Programa nesse sentido?

DET2: Que eu saiba, se tiver, é mais pontual, das pessoas em si.

Sandra: Não há uma preocupação...

DET2: Preocupação há, preocupação há sim, uma preocupação com a evasão, com a assiduidade, com tudo isso, mas acho que...

Sandra: Digo uma preocupação no sentido de levar a uma ação concreta.

DET2: Acho que falta definir isso enquanto prioridade. No âmbito das possibilidades há discussão, mas não...

Sandra: Não está colocado como uma das prioridades. E o PIQ também no seu início estava previsto para atender jovens de 18 a 26 anos, Então um dos objetivos dele era justamente pagar uma bolsa auxílio para que esses jovens ficassem fora do mercado de trabalho, naquele sentido de não destituir do posto de trabalho um pai de família, uma pessoa já inserida no mercado de trabalho. Quando o PIQ foi para as escolas na verdade o que a gente viu, e os dados mostram isso, que não foram os jovens basicamente que foram buscar o PIQ. Tinha uma concentração de faixa etária justamente acima dos 25 anos. E hoje por todas as questões legais pela quais o PIQ foi passando inclusive para sua autorização legal, hoje a gente tem jovens mais jovens ainda no PIQ. Então como que você vê, essa questão de você ter, ainda o público prioritário nosso, não os jovens, mas vem caminhando lentamente para que isso aconteça, por todo o processo de exclusão da rede estadual que vem acontecendo e que a gente recebe os nossos alunos, os mais jovens. Como que você vê, por exemplo, você ter no mesmo programa, na mesma sala de aula jovens de 14, 15 anos com pessoas com mais de 50, 30 ou 40, no que toca, por exemplo, à qualificação profissional.

DET2: Eu acho que não se deveria fazer isso. Na minha opinião, não deveria. A gente passou por programas aqui que pegavam jovens de 14 a 17 que era o PEMT e que tentava manter esse aluno no ensino formal e se dava uma introdução ao mundo do trabalho, mostrava as dificuldades que é ingressas no mundo do trabalho, ingressar numa empresa, buscar trabalho alternativo e pegava esse filão, dos 14 ao s 17 . Na minha opinião deveria ser resgatado isso e incentivado que o aluno de 14 até 17 voltasse ao ensino formal.

Sandra: À escola regular. 
DET2: É. E infelizmente não foi esse o caminho. Quando você coloca de 18 a 26, seguiu muito as discussões do início do PROJOVEM. Mas se mostrou que não se atingiu essa população, mesmo com o PROJOVEM. Tanto é que o próprio PROJOVEM está alterando, está colocando de 18 a 29 anos hoje. Quanto à relação da bolsa, vai se buscar isso. Infelizmente a gente tem a intenção, tem a vontade, mas as relações concretas dentro da prefeitura, dentro do poder público também são outras e aí não se consegue.

Sandra: Estou fazendo essa pergunta justamente por isso, porque no início do Programa.

DET2: Aquilo que eu já te falei, mesmo com a qualificação profissional, é uma base, pela intenção, que a intenção é buscar melhorar, se aprofundar nisso, a própria dificuldade acaba...Mas é isso mesmo que você falou a intenção era não fazer com que o adulto perdesse o emprego em detrimento aos jovens, que tem um salário reduzido...

Sandra: É, para que eles não entrassem no mercado em condições tão precárias.

DET2: O jovem tem o direito de estudar, sem ter que ir am mercado de trabalho.

Sandra: Agora a gente vai entrar um pouco na gestão do Programa. Quais são os níveis de participação no Programa que os diferentes agentes têm? Professores, alunos, o próprio núcleo pedagógico, qual o nível de interferência nas discussões do Programa ou nas sugestões de alteração, ou na avaliação que essas pessoas têm?

DET2: As equipes locais podem intervir, podem suscitar cursos, suscitam cursos, colocam qual é a avaliação dos cursos, a direção do Departamento ela determina os cursos. Em relação aos alunos acho que a equipe local não conseguiu fazer essa comunicação, essa interlocução. Se usam alguns dados, entre aspas, do Observatório, acho que o Observatório não conseguiu atingir aquilo que ele também foi pensado anteriormente de estar balizando, de estar mostrando onde tinha maior possibilidade de empregabilidade, de se criar trabalho, agora vamos lançar essa discussão sim, acho que a equipe local tem condições de estar sentando AP's com a direção, a direção traz para cá e discute com a coordenação, a coordenação leva para as reuniões de departamento. Muitas vezes as pessoas não percebem essa dinâmica, por causa das hierarquias.

Sandra: Mas você está dizendo com relação a proposição de cursos, mas eu digo na estrutura geral do emprego.

DET2: Mas o que? Seja mais específica.

Sandra: Por exemplo: tempo de duração, a formatação mesmo do Programa, vai ter módulo, vai ser anual, vai ser semestral, vai ser isso ou aquilo, ...

DET2: Os alunos acho que nunca tiveram essa discussão, nem sei se eles têm condição para isso. Agora em relação às equipes locais...

Sandra: E os professores?

DET2: Quem deveria estar vendo isso e que a gente sempre bate com a equipe de direção é que seja escutado do professor, que se converse com os professores, que se discuta isso. Quanto a isso acho que é feito e se não é feito, deveria ser verificado com as diretoras porque 
não está sendo feito. Agora, há uma abertura para essa discussão, o que se chega aqui é discutido, é levado em consideração. Quanto a isso não tem uma camisa de força.

Sandra: Então nesse sentido eu queria saber qual é a orientação que o Departamento dá com relação a gestão das unidades, qual é a concepção de gestão das escolas que o Departamento orienta às diretoras?

DET2: É dado as linhas do Programa, é comentado com a diretora que discuta as ações com sua equipe, que pegue as informações e que passe as informações, que discuta, que aprofunde não só com a equipe da prefeitura mas com o convênio, e nessas discussões é trazido para as reuniões de diretora aqui no Departamento, para se colocar. O problema que eu vejo é que não é trazido para cá, não é feita a discussão sobre duração de cursos, sobre mudanças nisso. Eu poderia falar assim, deve ter tido algum problema, porque os professores estão questionando isso, então temos que ver, acho que no fluxo desse caminho o que está acontecendo, por que não é feito. Posso até avaliar aqui que pode estar ocorrendo de acordo, dentro dos parâmetros que a equipe local prevê.

Sandra: Mas a equipe local não tem autonomia para mudar o Programa na escola, ela segue a orientação...

DET2: É claro, ninguém tem, também gostaria de ter vontade de mudar todo o programa de governo, mas eu não vou mudar, não tenho condições disso, que eu faço, uso mecanismo e locais que são dados para poder colocar idéia ou idéia do meu grupo. O que eu acho é que é utilizado pouco esse recurso. É eu acho que as equipes locais trabalham pouco essas discussões e cobram pouco de sua direção para que faça essas mudanças, aqui, internamente.

Sandra: E você atribui isso a que?

DET2: Eu falei lá na frente, lá atrás, que acho que houve uma falta de vontade, ou uma falta dos próprios profissionais, acho que o pessoal se acomodou um pouco, acho que não está fomentando mais como se discutia antigamente. Não sei se pelo tempo, eu só acho que as pessoas estão apáticas ultimamente.

Sandra: Você falou das entidades conveniadas. Qual é o papel delas no Programa?

DET2: Deveria ser de discutir o Programa, levando discussões sobre o direcionamento do Programa, tempo de duração, público, tudo isso deveria discutir.

Sandra: Mas elas têm uma atuação maior que essa.

DET2: Em relação ao que?

Sandra: Dentro do Programa. Eles também fazem contratação dos profissionais...Então, qual é o papel delas?

DET2: Junto com a prefeitura, para poder atingir os objetivos do Programa, então a prefeitura faz o repasse, e a entidade faz as contratações e a discussão do programa junto com a prefeitura. 
Sandra: Você diz que deveria ser, mas não ocorre?

DET2: Em relação a que?

Sandra: A estarem participando da discussão, da proposta...

DET2: Acredito que de certa forma estão concordando com aquilo que foi colocado para eles. Desde o profissional, desde o AP, desde o professor, desde o diretor, desde a entidade conveniada, no momento em que para, que fica apático, se deixa que o Departamento dê as linhas e não se questiona o que faz, houve uma aceitação, uma acomodação, de alguma forma está tranqüilo, seja nos seus aspectos pessoais ou na sua falta de perspectivas mais gerais. Mas acho que há uma satisfação, por mais que se reclame, há uma acomodação da coisa. Está mantendo alguns objetivos pessoais das pessoas.

Sandra: Qual o papel do Observatório?

DET2: O papel do Observatório era estar avaliando informações da sociedade geral, do entorno para poder orientar a criação e a orientação dos programas, qual curso que vai ser construído, se o Departamento está colocando que o curso de marcenaria vai ser criado o Observatório deveria ter dados para que falasse, realmente esse é um curso ou não, não se deve criar tantas turmas, mais, menos turmas, em relação a evasão ele deveria ter um acompanhamento melhor, o pessoal que passou pelos programas deveriam ter um acompanhamento para ver se estão atingindo os objetivos, tanto aqui nos instrumentos da qualificação como na continuidade dos estudos, esse era o objetivo do Observatório que ainda o é.

Sandra: E você acha que ele atinge?

DET2: Acho que não a contento.

Sandra: Agora a gente vai falar da formação dos quadros. Falamos das diretoras, da formação delas, de como as equipes deveriam estar gerindo os Centros, então ia te perguntar o seguinte: com relação a corpo docente, quem forma este corpo docente e como é feita sua formação? Pensando nos princípios do Programa e em tudo o que ele tem.

DET2: As diretoras são da própria rede, não pode ser diretora....

Sandra: Não, estou falando dos professores.

DET2: A orientação deveria ser das AP's das paradas pedagógicas, deveria ter mais discussão, maior orientação quanto às atividades, os profissionais são contratados frente a um saber supostamente delegado a eles.

Sandra: Os contratados pelos convênios.

DET2: Isso. O professor de marcenaria tem que ser marceneiro, tem que ter tido experiência na área de marcenaria. Há uma avaliação das AP's e da diretora de sua atuação enquanto instrutor, a mesma coisa o professor que é contratado pelos convênios, o professor de biologia, as AP's elas fazem aquela avaliação do processo, nos acompanhamentos diários, no acompanhamento de fechamento, na postura do próprio profissional. Já em relação ao pessoal 
aqui da prefeitura, os funcionários, existe um limitador. As AP's da prefeitura você pode estar fazendo a troca, pode estar avaliando, é feito isso pela coordenação e pela direção. Agora, a qualificação desses profissionais a secretaria sempre tenta ver a alternativa para ser feito isso. Então o Ação Escrita é uma formação para os AP'S. O curso de pós que as diretoras e a equipe diretiva da secretaria está fazendo é um curso de formação em que se busca a melhoria da qualidade.

Sandra: Então a formação dos professores é responsabilidade do s AP's?

DET2: Não só. É uma orientação dos AP's e a gente busca que o próprio profissional, a gente fomenta isso, ao incentivo de que o professor se aprimore para buscar conhecimentos. $\mathrm{O}$ problema é muitas vezes o horário, como que se fez uma formação com o profissional que atua os três períodos, atua um período aqui e outros dois em outro lugar. Tivemos experiências aqui de buscar cursos fora, disponibilizar no período do sábado e o professor não aparecia. A própria equipe pedagógica não aparecia. Hoje falar de formação de professores está mais no nível de orientação dos AP's, da coordenação, dos diretores do que uma formação mais específica. É um desafio. Poderia se pensar em cursos, programas de férias, mas eu acho que toda a formação que a gente acabou experimento quanto aos professores teve baixa freqüência. Acho que a vida que se da ao professor hoje não dá espaço para ele busca aprimoramento, então ai se espera que ele se aprimore no dia a dia, nas orientações ou que busque fora. Vou dar só um exemplo. Existe alguns professores que estão contratados no Júlio de Grammont, então agora nas férias, por causa daquele contrato de seleção pública eles estão trabalhando, vão trabalhar no mês de janeiro lá. Houve uma solicitação da diretora que os professores fizessem um programa, um aprendizado nas férias. Quando caiu isso para cá a primeira coisa que o pessoal questionou, mas vai ser liberado para uma formação individual para esse profissional? E no final das contas, na discussão final, vai ter que ser porque, se vai buscar isso no período de férias a Secretaria tem que estar incentivando, o Departamento tem que estar incentivando porque isso vai ser trazido para o seu dia a dia, para o seu trabalho diário.

Sandra: o que eu tinha para te perguntar era isso, outras que ficaram você respondeu dentro de outras que foram colocadas, agora queria que você fizesse os comentários finais, alguma coisa que queira dizer.

Milton: Acho que é isso...Feliz Natal.

Sandra: Já foi o Natal...

Milton: Pro ano que vem... 
$16 / 01 / 2008$

\section{ENTREVISTA - DET3}

Sandra: Hoje é dia 16 de janeiro, a entrevista é com..., coordenador do observatório. Bom dia. Gostaria que você se apresentasse, falasse da sua formação, falasse de sua trajetória profissional, como você chegou até aqui a Secretaria e qual é o seu papel aqui.

DET3: Me chamo..., sou economista de formação, me especializei e me pós-graduei na UNICAMP em Economia Social e do Trabalho, atualmente sou mestrando em Economia do Trabalho na UNICAMP. A minha trajetória profissional, na verdade, ela começa como autônomo, trabalho com parentes, familiares, numa área que mexia com madeira, fabricação de móveis, por muitos anos, depois prestei concurso nos Correios e Telégrafos, trabalhei como executante operacional interno e posteriormente sai da área pública e fui para a iniciativa privada, numa empresa multinacional. Nesta empresa trabalhei no departamento de logística, fui programador e controle de produção. Nessa empresa também acabei vivenciando situações junto aos trabalhadores e acabei atuando junto a CIPA, e depois fui eleito para a comissão de fábrica. Posteriormente passei por um processo de demissão por justa causa, em decorrência da luta dos trabalhadores. Então essa questão dos estudos, vinculada a situação dos trabalhadores sempre esteve pautado na minha vida. Posteriormente, como parte da conclusão do meu curso de ciências econômicas, fiz um estágio no Primeiro Emprego Jovem Cidadão, do governo do estado, junto a Secretaria de Relações do Trabalho, junto ao Barelli que também foi um dos técnicos do DIEESE. E por lá além de ser um dos coordenadores desse programa, acabei tendo oportunidade de conhecer o Observatório do Futuro do Trabalho. Então, a partir desse momento eu passei a articular um pouco essa questão do desenvolvimento econômico com a questão do desenvolvimento da educação e do mundo do trabalho, como é que isso se dava de forma integrada. Com os conhecimentos e estudos da UNICAMP também me possibilitou enxergar as situações, as diversas situações do mundo do trabalho e da educação de forma integrada. A partir da UNICAMP tive a oportunidade de conhecer um trabalho incipiente que estava sendo iniciado aqui em Santo André, através da criação e constituição do Observatório da Educação e do Trabalho, e acabei recebendo um convite para vir para cá. Mandei um currículo, eles apreciaram os meus conhecimentos e chegando aqui pude me deparar com uma novidade que era exatamente a articulação da avaliação das políticas públicas, dos programas, e das ações que vinham sendo encetadas aqui na cidade. Iniciei como um dos técnicos, um consultor, e posteriormente fui guindado à situação de coordenador do Observatório da Educação e do Trabalho. Então desde aquele período até o presente momento, nós fizemos uma série de diagnósticos, e principalmente nos preocupamos com a estruturação das informações. Quer dizer, muitas informações dispersas, então todo esforço nosso desde aquele período até o presente momento, vem nesse sentido da constituição de um banco de dados, de sistematizar as informação e ao mesmo tempo organizá-las de tal forma que pudesse ser utilizada pelos diversos atores da Secretaria de Educação. Então em um primeiro momento o observatório estava vinculado ao DET e com o seu desenvolvimento, com o avançar das atividades foi também convidado a compor o gabinete da Secretaria de Educação e passou a cuidar de todos os dados da Secretaria, dados esses já não dados primários, já recebia eles no formato de dados secundários. Os únicos dados que eram primários e que ficaram sob a responsabilidade do observatório foras os dados do DET, dado sua estrutura de funcionamento. Hoje, passado essa trajetória toda, rapidamente aqui pinçando o papel que eu constituo no Observatório é principalmente de análise, uma vez que a equipe do Observatório foi dispersa pelas diversas ações que o DET vem encetando, inicio o ano de 2008 só, ou seja, somente o coordenador tem esse papel de 
estar sistematizando as informações já existentes sobre educação e o mundo do trabalho e fazendo análise dos dados que são coletados pelo observatório. Então quer dizer, acabo centrando um pouco mais na essência do observatório que é a avaliação de políticas públicas a partir da análise de dados empíricos e de situações dadas. Então esse é um pouco meu papel hoje e também sou coordenador de programas, dada essa dupla ação dentro da Secretaria de Educação acabo tendo que acompanhar alguns programas diretamente, como o PMQ, o Programa Municipal de Qualificação profissional da cidade e em especial as reuniões de coordenação pedagógica, as reuniões com as diretoras que o DET efetua. E por vezes, quando sou solicitado, nos mais diversos problemas da Secretaria de Educação e Formação do trabalho eu também acabo participando de ações específicas, ajudando na análise, na apresentação de situações na Secretaria.

Sandra: Tem alguns blocos, alguns campos pelos quais eu queria transitar, conversando com você. Primeiro, queria que você dissesse o que você entende, qual é ou qual seria o papel do Observatório para o DET? Se não é o que ele consegue executar, mas qual seria o papel do Observatório?

DET3: Até o presente momento cumpriu um duplo papel. Até 2007 ele tinha uma equipe semi-completa. Cumpriu um papel ao mesmo tempo de efetuar o monitoramento dos programas, de diagnosticar antes da implementação de um programa ou até mesmo trazer um projeto pra cidade como é o caso do PROJOVEM, efetuamos um diagnóstico, preparamos dados, encaminhamos documentos, tudo por conta da elaboração do observatório por solicitação do DET. Ao mesmo tempo o observatório cumpriu e vem cumprindo o papel de captação de recursos, através de novos programas ou de editais que são abertos, seja pelas instituições de fomentos privados, seja nas instituições públicas, governo federal em especial. Então o observatório cumpre o papel de organizar e certificar, ou seja, ele que dá o último parecer antes da assinatura do diretor e do responsável por cada Centro Público, em relação ao certificado de cada aluno que foi promovido através do exame nacional de educação de jovens e adultos, o ENCCEJA. Então esse é um eixo que o Observatório tem atuado e que se encontra sob responsabilidade do Observatório, sob minha coordenação. Outro eixo do observatório é o monitoramento, que consiste na organização dos mapas de movimento e dos bancos de consolidação. Ou seja, nós checamos cada dado, de cada aluno, seja do perfil dele, de sua trajetória, da sua condição de educação dentro de um centro público, num dado período histórico, ou seja, ao longo do ano. Esses dados vêm para nós, sistematizamos e transformamos em um dado estatístico, que procura junto com a ata de resultados ao final do ano, ele procura aferir, tanto a quantidade de alunos que foram promovidos, quanto os que foram retidos, como os evadidos, bem com em que nível de conhecimento esses educandos foram promovidos na língua portuguesa, na matemática, nas mais variadas disciplinas que integram o PIQ. Esse é um trabalho de monitoramento sistemático que nós fazemos, desde os dados primários transformando inclusive em dados secundários, para posterior uso. $\mathrm{O}$ terceiro eixo do observatório é o planejamento, onde tenho uma atuação mais direta, todas as reuniões que demandam planejar uma ação, uma atividade ou um programa, ou até mesmo efetuar correções de rumos, eu sou chamado para participar dessas reuniões, para ajudar a decidir, pontuar, apresentar novos pareceres ou outras posições junto ao contexto sócio-econômico em que estão envolvidas essas atividades ou programas. O quarto eixo refere-se à captação de recursos. Junto com a equipe eu ajudo no chek list, ajudo a pontuar, a apontar novos caminhos na preparação e elaboração de projetos, que serão encaminhados a essas instituições de fomentos com vistas a trazer recursos pra cidade. Tem hoje uma equipe pequena que trata especificamente da elaboração de projetos, captação de recursos e entrega então nas mãos dos coordenadores pedagógicos, ou dos coordenadores de programa do Departamento, para que 
esses projetos sejam implementados na cidade. O quinto eixo, que independe a ordem dos fatores, que é o específico, que é onde o Observatório faz o que é a sua essência, a sua premissa, que é a avaliação dos programas. Recentemente, no ano de 2007, fizemos uma avaliação completa de toda a EJA no DET. Esse material foi escrito, devolvido para os educadores, que estarão trabalhando ao longo de 2008 no seu $\mathrm{PPP}^{27}$. Pudemos avaliar, desde o PIQ I Alfa, Pós, PIQ II Inicial e Final e o PIQ III, então todas as modalidades e todos os níveis de existência do PIQ. Consideramos que do ponto de vista do objetivo do observatório, esse sendo o eixo principal, é ele quem vai dar o imput, o insight, pra alterações futuras e presentes do Programa, com vistas sempre a efetividade social. Tudo o que a política pública realiza e pode fazer, o observatório entende que tem que ter um resultado para a população, para o conjunto da sociedade. Em geral, esse resultado se possível é bom que seja direto, se não for direto, que contribua de forma muito relevante, indiretamente, para todo o conjunto da sociedade, inclusive articulado com o desenvolvimento econômico, com a geração de trabalho e renda para a população, ou seja, como é que ele contribui com pesos, porque sabemos que a educação por si só não gera trabalho, não gera empregos, mas tem uma grande contribuição na evolução social e da organização da sociedade. Então hoje o Observatório tem esse papel preponderante de cumprir a essência desses cinco eixos, principalmente a avaliação, sem deixar de lado, de orientar, monitorar e passar as diretizes desses outros eixos. Como eu disse há pouco, inclusive, o Observatório embora ele tenha sido enxugado e parte de sua equipe descentralizada para o conjunto do DET, isso se deve exatamente pela qualidade de seus técnicos, ou seja, o Observatório não deixa de dar essas orientações e essas diretrizes para essas pessoas e para esses eixos.

Sandra: Do que você falou vou fechar agora dois blocos para a gente conversar. Tem a questão do financiamento, que eu queria que você falasse. Você falou de se articular a entrega de projetos para outras instituições a fim de trazer verbas, recursos, enfim, tem essa questão. E tem uma outra questão, que é a da proposição dos cursos, a partir dessa avaliação prospectiva que o Observatório faz, ou deveria fazer. Então eu queria que você falasse quanto a financiamento. A gente sabe que um dos problemas do PIQ, por conta de trabalhar com formação profisssional é não ter a vinculação de verbas para essa modalidade, ou para essa área. A gente tem verbas da educação, agora tem o FUNDEB, mas especificamente uma linha de financiamento para formação profissional, fora aquilo que vem do FAT ou de um ou outro projeto, a gente não tem uma linha de financiamento para isso, então isso sempre gerou problemas com relação ao financiamento. Como é que o Observatório lida com isso, por exemplo, quando vai avaliar o Programa? Por exemplo, quando vai avaliar a qualidade dos cursos, de que maneira essa questão do financiamento afeta o programa e que saídas você acha que seria possível?

DET3: O aspecto do financiamento é um problema que está presente em todas as dimensões da sociedade. Quando a gente tenta aprofundar uma política que dê um resultado maior para a sociedade, nós nos deparamos com os aspectos da institucionalidade. Nunca a institucionalidade consegue dar conta das necessidades de políticas mais avançadas que possam atender de fato o conjunto das necessidades da população e em especial a formação profissional. Embora tenhamos o decreto 5154, tivemos alguns avanços ao longo desses últimos dez anos, podemos perceber que ainda a carência é muito grande de recursos específicos para essa área. O Sistema $\mathrm{S}$ consegue dar conta das suas necessidades, no entanto de certa forma, existe uma ausência de articulação dessas políticas que estão vinculadas ao Sistema S, mesmo dos cursos das escolas federais, escolas técnicas, tanto as FATEC's quanto

\footnotetext{
${ }^{27}$ Plano Político Pedagógico.
} 
as escolas federais propriamente ditas, carecem de uma articulação maior com as políticas municipais, e aí os municípios, dado a especificidade do direcionamento do recurso com base na LDB, dos $18 \%$, dos $25 \%$ do estado, dos recursos próprios do município, ele acaba tangenciando determinadas perspectivas de programas que você possa vir a constituir. O PIQ é um desafio nacional, ele tem uma especificidade própria, porque ele pretende articular um feixe de políticas, para dar conta das necessidades da população, principalmente tendo como essência a formação profissional. E nesse aspecto nós tivemos que, e quando formatamos o programa e o Observatório participou diretamente junto com os educadores e demais professores da secretaria nessa formatação, nós o formatamos com vistas a ter recursos próprios e ao longo do percurso nós pudemos verificar que isso não se viabilizou. Dada a falta de institucionalidade, ou seja, legislação específica que direcionasse recursos pra ele e nós tivemos então, que vir fazendo adaptações desse programa com vistas a ele se encaixar dentro da política de educação de jovens e adultos, portanto a EJA, vem numa luta nacional e algumas lutas mais específicas, conquistando recursos dentro do FUNDEB que agora, recentemente foi aprovado. Você está limitado pela responsabilidade do município, que no máximo ele pode se responsabilizar até o ensino fundamental, e portanto uma das modalidades desse programa acaba ficando de fora, e acaba ficando dependente das parcerias com convênios, com entidades, e de projetos que a gente possa captar recursos. O observatório constatou isso, como é que isso rebate na programação, no itinerário formativo e nos cursos que são ofertados. Ele rebate a partir das limitações do que se pode gastar com recursos municipais e do que você consegue captar tanto com recursos do FAT, como até mesmo com outros recursos de programa específico como podemos citar o "Costurando Renda" que é um recurso trazido através da Secretaria Nacional de Mulheres, com vistas a formação para 100 mulheres, na área de moda, de corte e costura.

Sandra: O "Costurando Renda” não está atrelado ao PIQ.

DET3: Ele não está atrelado ao PIQ, então é um exemplo disso, nós conseguimos trazer o recurso da formação profissional para essas mulheres, articulado inclusive com o conhecimento de elevação de escolaridade, sem poder certificar com certificado de elevação de escolaridade, ou seja, nós não conseguimos articular ele junto com o PIQ, mesmo tempo um esforço de estudo de tentar viabilizar. Com o PMQ existe uma tentativa de, para o ano de 2008, também tentando nessa linha, articular o PMQ com o PIQ, ou seja os três eixos do PIQ, que são elevação de escolaridade, conhecimento do mundo do trabalho em uma área, uma profissão, na ocupação profissional, e ao mesmo tempo uma experimentação para o mundo do trabalho in loco, ou seja, um estágio social, podendo ser na iniciativa privada como podendo ser nas entidades sociais. Esse aspecto do financiamento o Observatório vê sim, como um problema para avançar e aprofundar essa política integrada do PIQ junto ao DET. Por outro lado, a gente vê com bons olhos os esforços que tanto o prefeito na condição de responsável pela gestão, todas as pessoas que estão envolvidas na secretaria de educação, um esforço muito grande pra estruturar os centros públicos de formação profissional, estruturar com equipamentos, obviamente dentro dos recursos que a legislação permite efetuar seu gasto. Quais são as saídas que o Observatório vem identificando nesse sentido. Primeiro, nós temos que estabelecer junto ao FAT uma articulação mais aprofundada em relação ao próprio PMQ. Não dá pra ter sobreposição de políticas de formação profissional na cidade, política também que a secretaria de desenvolvimento econômico e o departamento de geração de trabalho e renda também defende, então juntos, a secretaria de educação, a secretaria de desenvolvimento Econômico e ação regional e os dois departamentos, o Departamento de Geração de Trabalho e Renda e o Departamento de Educação do Trabalhador vêm efetuando esforços nesse sentido, de buscar um arranjo político e que dê uma institucionalidade junto ao 
FAT para que a gente consiga um recurso específico pra esse tipo de formação de política integrada. Essa é uma das saídas que vem sendo trabalhada desde o final de 2007. A outra saída refere-se à elaboração de projetos e captação de recursos. Temos identificando que esse tipo de política se por um lado, ajuda a somar e trabalhar com ações complementares, por outro lado ela tem uma deficiência na formatação dos editais, quer dizer, não contribui para dar sustentabilidade às políticas que os municípios vêm encetando, em especial os municípios que elaboram, que trazem projetos pros seus municípios. Achamos também que há que se mudar alguns componentes desses editais, possibilitando uma política de longo prazo, de maior fôlego, de três, cinco anos, por exemplo. Nada impede hoje que você elabore um projeto, ele seja bem sucedido e no próximo ano ele seja interrompido, não há uma continuidade, não há uma garantia de que no ano seguinte você pode mandar um novo projeto, na mesma linha de edital que tinha sido aberta e você vai conseguir o recurso. Talvez até não seja esse o objetivo das políticas do governo federal, mas de qualquer forma sentimos essa carência, essa alteração e a outra alteração refere-se à própria LDB, quer dizer, a LDB tem que procurar compatibilizar todos os níveis e modalidades da educação, em especial a formação profissional. Como é que a gente coloca dentro da política nacional, da LDB, que viabilize a ter recurso de forma eqüitativa pra formação profissional tanto pra jovens quanto pra adultos. A quarta questão que coloco refere-se ao próprio Sistema $\mathrm{S}$, como eu tinha dito anteriormente, há a necessidade de uma articulação dessas políticas, com vistas a potencializar e até a ajudar a iniciar um eixo de políticas integradas nos municípios. Não adianta cada instituição, cada autarquia tentar fazer uma política própria, a política tem que estar casada nos níveis que a sociedade está constituída. Se tem município, que o governo municipal é responsável pela cidade, o governo estadual pelo estado e o governo federal pelo país, essas políticas tem que estar concatenadas, elas tem que estar organizadas pra atender essas demandas e não cada instituição ter uma política específica, própria, mesmo considerando as limitações existentes que a gente conhece. Considerando esses quatro pontos a gente pode avançar nessa política, nada impede que você avance mais em um ou em outro, mas a tendência é que você busque articular essas quatro situações que eu apresento como saída para a proposição e implementação de política integrada mais efetiva. E aí o Observatório cumpre um papel nesse sentido de estar estudando, estar apontando, estar apresentando premissas e situações diagnósticas para essas instituições, dizendo olha, o que vocês estão fazendo hoje não tem muita efetividade social, porque ocorre sobreposição e não há contiuindade, não há sustentabilidade dessas políticas que vêm sendo feitas da forma como está. Então, esse é um dos papéis principais do Observatório, para inclusive justificar quando ele apresenta essas proposições, esses apontamento, ele em geral, ele apresenta junto uma avaliação dos programas e das políticas do uso desses recursos financeiros, diante das situações que estão postas.

Sandra: Fala um pouco da relação de vocês com a Secretaria de Desenvolvimento Econômico, como eu disse anteriormente, no sentido da prospecção do mercado de trabalho e da definição dos cursos. Porque a gente tem uma idéia corrente na sociedade de que Santo André é uma cidade que está se "desindustrializando", mas na verdade não é isso, quando você pega os dados esse processo não é assim tão profundo, o que você tem é uma terceirização dos serviços industriais, na verdade, então o crescimento do setor de serviços se dá muito mais porque as empresas vão abrindo mão daquilo que não é essencial à produção, então você tem uma diminuição dos postos de trabalho, por conta da reestruturação produtiva e você tem um aumento do setor de serviços, mas que não é só esse serviço doméstico, serviço mais voltado pras pessoas individuais, mas também é um serviço que está diretamente relacionado à indústria. E quando você pega os dados, que é um dos índices que os economistas usam que é o valor adicionado fiscal, ele tem uma variação que não é tão grande, o que mostra que a 
atividade industrial na cidade ela ainda é muito grande, agora o que não acontece com relação aos postos de trabalho, esses realmente tiveram um decréscimo e você realmente perdeu esses postos. Então, pensando que o PIQ trabalha na perspectiva da formação inicial e continuada, a gente não trabalha com ensino técnico, não trabalha com formação de quadro técnico, como vocês, junto ou não, com a Secretaria de Desenvolvimento Econômico, conseguem estabelecer um quadro, ou como o pessoal gosta de dizer, construir um cenário, onde haja uma proposição de cursos que se case com esta prospecção.

DET3: Acho que até é relevante porque calhou, como coordenador do Observatório não precisaria ser economista, mas calhou de eu ser o coordenador e ser economista. Quer dizer, com base nos estudos que eu tive pregresso e com base nos fundamentos da escola a qual eu participo como estudante, também, ainda, na condição de mestrando da UNICAMP, nós consideramos que se o setor industrial não estiver punjante, a economia vai ter dificuldades de crescer, vai ter dificuldade inclusive de distribuir sus riquezas e seus resultados de forma mais efetiva. Assim, praticamente o setor de serviços gira em torno do setor industrial, hoje no Brasil e em qualquer lugar do mundo. Salvo algumas exceções que gira em torno da tecnologia, mas também vinculadas à indústria e a produção de produtos de forma real, a economia real, como a gente chama. Nem sempre os indicadores conseguem dar conta dos dados e dos cenários que a gente olha ou analisa, mesmo o valor adicionado fiscal, ele nem sempre mostra o que está acontecendo na economia, ele mostra do ponto de vista do tamanho mais geral, quer dizer, teríamos que olhar a política setorial na cidade e na região do $\mathrm{ABC}$, e as suas articulações. Olhando pra isso primeiro que, de fato, passamos por uma década, a década de 1990 em especial, que ocorreu o advento da reestruturação produtiva com a implantação do neo liberalismo no nosso país e isso teve um impacto profundo na sociedade. Trabalhadores que recebiam recursos diretamente, que tinham uma série de benefícios, uma série de assistência social, eles perderam isso. Quer dizer, o que é a na verdade a terceirização, no que consiste a reestruturação produtiva, ela consiste na diminuição de custos, tanto do ponto de vista da quantidade de posto de trabalho, ou seja, a produtividade de um trabalhador que fica, ela aumentou de forma muito profunda, quer dizer, se você precisava pra produzir um determinado produto de tantas pessoas, você reduziu isso pra um terço. E as pessoas que foram colocadas pra fora, elas tiveram que inclusive buscar novas ocupações, elas não conseguiram mais buscar emprego na mesma ocupação em que elas estavam trabalhando anteriormente. E isso gerou um tipo de política de formação profissional, algumas encetadas pelo governo estadual, outras pelo governo federal e outras iniciadas e depois continuadas pelos municípios que a gente chama de requalificação profissional, que é buscar ou aperfeiçoar essa pessoa atualizando ela na mesma área em que ela estava, para ela tentar ainda, no mercado de trabalho, principalmente no espaço friccional do emprego, ou seja, sempre tem uma taxa entre a oferta e a demanda que fica ali, flutuando, por uma séria de decorrências, porque as pessoas não estão no lugar correto, estão em cidades diferentes, etc, então esses trabalhadores procuraram ocupar esse espaço, com base nessa formação de requalificação profissional. Outras, ao perceber que não conseguiriam retornar aos seus postos de trabalho, buscaram novos cursos, novos postos. Então essa é a forma com que se articula um pouco a formação profissional com a reestruturação produtiva. Agora, tendo claro, que a formação profissional não gera postos de trabalho, insisto nisso, e os postos de trabalho que foram perdidos por conta da reestruturação produtiva, pela implantação do plano neo liberal, em especial no $\mathrm{ABC}$, dificilmente eles retornam, até porque caso haja o aumento da produtividade em uma ocupação de toda a capacidade produtiva, as empresas tendem a utilizar as novas tecnologias, para ocupar esse espaço. Então um trabalhador que vá fazer um curso que não considere o conhecimento das novas tecnologias, novas áreas de trabalho, está fadado a ficar excluído do mercado formal de trabalho. Então é pensando nisso que a 
formação inicial e continuada se apresenta, principalmente de forma mais candente no PIQ aqui na cidade, buscando fazer com que esse trabalhador, ao mesmo tempo ele tenha capacidade de efetuar pesquisa, capacidade de buscar outras alternativas e capacidade de buscar caminhos que leve ele a uma emancipação fora dessa exigência do mercado formal de trabalho. Daí a articulação também com a Secretaria de Desenvolvimento Econômico e em especial o DGTR, com a nova política econômico popular e solidária, quer dizer, procurando propiciar a esses trabalhadores a possibilidade da formação de cooperativas, empreendimentos populares, e até mesmo um trabalho autônomo mais estruturado, que ele não fique sozinho nessa luta pela sobrevivência. Então daí a articulação dessa política. Qual é o cenário que a gente verifica, que esse processo vai continuar se aprofundando, porque faz parte das tratativas de competitividade. Se você não consegue competir com seu produto no mercado internacional e mesmo no mercado nacional, uma vez que a economia está aberta para importados, você corre o risco de falência. $\mathrm{O}$ empreendimento, a empresa falindo, gera mais desemprego. Agora, nós temos claro que empregos diretos é uma coisa, traz um rol de benefícios para o trabalhador, inclusive planos de saúde, e uma série de outras, alimentação, transporte, que o trabalhador autônomo não tem. Então quer dizer, compreendendo que dentro do cenário do mercado de trabalho você tem situações diferentes e complexas, você tem que preparar políticas que procurem dar conta dessas situações. Tendo claro que, na verdade você está fazendo uma política com vistas a contribuir com uma possível saída de forma mais efetiva. Como economista eu entendo que a saída mais efetiva passa pelo crescimento, pelo desenvolvimento econômico e pela redistribuição das riquezas desse país, quer dizer, os mecanismos que continuam concentrando renda pemanecendo, você pode estar fazendo um esforço de enxugar gelo. Você vai, cinco anos, dez anos, você toma medidas paliativas que não consegue efetivamente trazer resultados, todas as políticas quando elas são formatadas, implementadas, ela tem que contribuir para desmontar os mecanismos de concentração de riqueza. Não adianta você crescer cinco, seis por cento, e os mais ricos continuarem a ser mais ricos e os mais pobres continuarem na mesma situação, apenas acompanhando alguns elementos de crescimento da sociedade, por exemplo a educação. Você consegue notar que a maioria da população tem aumentado os anos de escolaridade, você consegue perceber que as pessoas conseguem obter ocupações profissionais nas áreas mais técnicas, mas em quais empregos mesmo? Nos empregos mais precários, não são os empregos principais, esses ainda continuam ser ocupados por uma elite que advém de uma situação de concentração de riqueza e renda da sociedade, que é uma distorção que ela precisa pelo menos no poder público, precisa começar a ser corrigida. É dessa forma que eu entendo como economista, como coordenador do observatório todos os trabalhos que a gente tem realizado. Muito cuidado com os indicadores e com o que eles nos mostram, mesmo sendo indicadores criados por nós mesmos. Por exemplo, o VAF. Ele é de certa forma, um indicador sistematizado e aprimorado pelos nossos amigos do Observatório Econômico, é um excelente indicador, mas não significa que ele dê conta de todas as nuances de como a economia se apresenta.

Sandra: No caso, a gente estava tratando da desconcentração industrial e o VAF vem para dizer que não é bem assim.

DET3: Porque a terceirização na verdade, Sandra, ela apresenta características diferentes, é isso um pouco o que você falou, as pessoas saem das empresas, algumas vezes até recebem alguma parte dos maquinários, para constituir uma nova empresa para prestar serviço para as grandes empresas, mas há casos em que a maioria dos trabalhadores não vão trabalhar terceirizados, eles estão fora mesmo do mercado, então a reestruturação produtiva também aponta, embora possa dizer que ela não foi tão profunda assim, também aponta que há uma desconcentração industrial ocorrendo no $\mathrm{ABC}$ e junto também ocorre a substituição de 
trabalhadores por novas tecnologias, mais lento, é claro, porque o advento da terceirização é mais profundo do que o uso dessas novas tecnologias. Agora, está mostrando que o caminho na área de serviços embora esteja em crescimento o setor da micro e pequenas empresas esteja em crescimento, ele ainda depende da pujança que as grandes indústrias possam dar aqui na região do $\mathrm{ABC}$.

Sandra: Falando sobre os cursos. Uma das ações do Observatório que pelo que eu tenho observado e mesmo em outras entrevistas é que o acompanhamento de egressos é uma questão complicada e ela seria fundamental para avaliar o que esses cursos estão dando resposta ou não a esse problema que está. Você tem algum dado que já indique isso, que não seja só aquele retorno pontual, porque pontualmente um aluno ou outro vem dizer, ah, porque eu montei um salão de cabeleireiro, porque estou trabalhando numa casa como cuidador de idoso, mas há dados que mostrem isso, mesmo não tendo efetivado pesquisa de egressos, o que vocês têm de retorno que não seja essa fala esporádica dos alunos que mostre que a proposição dos cursos de alguma maneira responde ou não a isso.

DET3: Correto. Acho que vale a pena tocar um pouco nessa questão da proposição dos cursos. Como nós detectamos que o mercado de trabalho ele é muito heterogêneo, nós procuramos atender essa heterogeneidade, lembrando sempre que nosso público alvo são exatamente aquelas pessoas mais carentes, as menos preparadas, nossos critérios para entrada nos cursos são bastante específicos. São pessoas moradoras da cidade que estão desempregados, em famílias desestruturadas, ou seja, as piores condições são essas em que se encontram. Dado isso, temos que trazê-los para cursos que contribuam na sua inserção não no mercado de trabalho precário, ms no mercado de trabalho eu ele inclusive consiga vislumbrar perspectiva para sua vida de futuro. E como é um trabalho que consideramos recente, nós estamos assim no meio do caminho. Primeiro, tentando ofertar cursos que ajude ele de forma efetiva a ficar um longo, maior tempo possível dentro do mercado de trabalho. Nós sabemos que a rotatividade do trabalhador é muito grande em diversas ocupações profissionais. Por exemplo, na área de telemarketing, o Observatório com base em seus estudos orientou e propôs ao DET que esse curso não fosse ofertado, pelo menos não com recursos públicos do município, articulado com elevação de escolaridade, por conta de que tinha um grande número de pessoas formadas e o mercado estava usando essas pessoas como mão-de-obra rotativa, inclusive rebaixando o valo dos salários que chegou em 2001 a pagar $\mathrm{R} \$ 740,00, \mathrm{R} \$$ 800,00 em algumas empresas, caiu para $\mathrm{R} \$ 450,00, \mathrm{R} \$ 430,00, \mathrm{R} \$ 500,00$ agora no presente momento. Então embora ainda tenha sido ofertado por alguns convênios, algumas instituições parceiras, nós não propomos que seja ofertado esse tipo de curso. Isso significa que quando o trabalhador vai para o mercado de trabalho nós temos a dificuldade de acompanhar essa ida dele e a permanência. Porque uma pesquisa de egressos tal como a gente queria que fosse feita, ela deveria ao mesmo tempo acompanhar a entrada desse trabalhador e acompanhar um período dele dentro dessa empresa e procurar mensurar qual peso os cursos que ele fez dentro dessa ocupação que ele está fazendo, dentro dessa atividade que ele está exercendo. Determinar qual é o peso não é uma medida simples. Você teria que dentro de um questionário elencar uma série de elementos para tentar identificar esses pesos. Isso teria que ser feito pelos menos dois, três anos, para inclusive verificar se os cursos que nós estamos ofertando também não está contribuindo para a rotatividade da mão-de-obra porque pelo CAGED você consegue identificar a rotatividade da mão-de-obra no mercado de trabalho, a oficial. O autônomo é muito mais difícil. Que nós temos verificado, que embora não tenhamos efetuado, colocado em prática uma pesquisa de egressos, nós temos recebido, nas formaturas em especial, uma quantidade razoável, que aí gira em torno da ordem de vinte por cento, não 
mais do que isso, do retorno das pessoas que conseguiram trabalho apenas pelo fato de estarem estudando.

Sandra: Não necessariamente ligado a qualificação.

DET3: Não necessariamente. Porque uma das grandes exigências e demandas dos empresários se refere exatamente ao nível de escolaridade. Se as pessoas têm o ensino fundamental, para elas são ofertados determinados tipos de trabalho, se ela tem o ensino médio, são ofertados outros tipos, e assim sucessivamente. E se essas pessoas estão estudando, já conseguem obter emprego inclusive ao longo do processo de escolarização,agora ao término a dificuldade é muito grande. Realmente a gente só recebe informações esporádicas das pessoas que estão estudando. O Observatório tem preparado o instrumento da pesquisa de egressos, precisa de recursos para implementá-lo, inclusive já buscando contemplar esses elementos de qual peso os cursos estão contribuindo na vida dessas pessoas. No entanto até o presente momento não conseguimos colocar essa pesquisa de forma específica em campo. O que nós conseguimos fazer foi pesquisa de evasão, que ai sim, inclusive num dos nossos relatórios aqui apresentados, que aponta, que no relatório da EJA de Santo André, que vai de 2001 a 2007, nessa pesquisa aponta que $40 \%$ dos alunos que evadem o motivo é relacionado ao emprego, a busca de um novo emprego, e desses $18 \%$ começaram efetivamente a trabalhar e 17\% tinha o horário de trabalho incompatível com o horário de aula. Então nós verificamos que com base nessas informações que o Observatório levantou sobre evasão, já ajuda a complementar um pouco o que não temos na pesquisa de egressos, então nós fazemos por inferência, com base nas informações que conseguimos até o presente momento.

Sandra: Queria que você falasse dos itinerários formativos, porque o PIQ quando começou trazia nele a idéia do itinerário formativo que começaria lá no PIQ I e iria até o PIQ III. Itinerário formativo aí pensado na idéia de construção de uma carreira, enfim. Durante os anos de 2003 para cá tiveram diversas alterações nesse sentido. Em determinado momento a formação profissional foi oferecida só no PIQ III, como foi o caso de 2007, em 2007 ela voltou a ser ofertada no PIQ II, isso foi uma orientação do Observatório, o que gerou isso? Isso rompe com a idéia do itinerário? Porque o PIQ II trabalha com a idéia da inclusão digital. O PIQ II, Inicial e Final, e o III, até tenta construir um itinerário mas nem sempre é possível e então em 2006 se rompeu com essa idéia porque só o PIQ III trabalhava com qualificação. Foi o Observatório que orientou isso e porque que agora se retomou essa formatação?

DET3: Bem, o PIQ na verdade ele foi elaborado lá nos idos de 2003 com vistas a atender a necessidade dos trabalhadores. Você tem trabalhadores principalmente na construção civil que começam a estudar e daqui dois meses têm que sair justamente por conta do trabalho em outra cidade, como disse agora a pouco, relativo ao relatório de evasão. Nós tentamos implantar o PIQ de forma integral, começamos pelo primeiro eixo, elevação de escolaridade, o segundo eixo da formação profissional e o terceiro eixo que foi tentado implantar a partir de sua institucionalização, a partir da Lei do PIQ do ano de 2005. O que que nós nos deparamos: os recursos públicos. O nosso grande limitador e o que fez com que essa alteração fosse ocorrendo desde o início do projeto integral e integrado como estava sendo posto, fosse alterado ao longo desses anos, com vistas à institucionalização do Programa e com vistas a garantir uma sustentabilidade maior para atender nossos educandos. O Observatório realizou estudos com bases nessas necessidades e nessas alterações, sempre apresentou proposição e alternativas que viesse a atender a implantação de forma integral tal qual ele tinha sido proposto. Agora, as dificuldades foram se deparando, o DET foi tomando as decisões de 
ajustá-lo, não foi por orientação do Observatório. Ele fazia as ressalvas, olha é por aqui, mas vocês têm esses limitadores, mas apresentava as limitações e cabe sempre ao DET no seu coletivo ou em última instância na pessoa do diretor, tomar a decisão de continuar mantendo o Programa, quer dizer, perde-se os anéis, mas mantém-se os dedos para ele continuar funcionando sempre pensando em ganhar tempo para que lá na frente você consiga retomar ele tal qual estava proposto. Nosso papel é apresentar as limitações e como ele deve ser implementado. Isso sempre foi feito, em documento, em reuniões, em apresentações e mesmo no planejamento. Por exemplo nós propusemos para o ano de 2005 e 2006 o curso de, que mexeria com calderaria, novos cursos, e o que o DET se deparou, que não tinha recursos suficiente para bancar máquinas, materiais para poder ofertar esse curso, nós pressupomos que esses cursos poderiam ajudar melhor a população a se integrar no mercado de trabalho, então articulando por exemplo, a confecção de portões eletrônicos, portões de aço, janelas, articulando isso com a questão da segurança, com chips, fiação eletrônica, vincular alguns produtos com a questão da telecomunicação. Não foi possível por conta de recursos. Quer dizer, os recuos que o DET teve que dar e os ajustes do Programa, como você apresentou aqui, quer dizer o itinerário formativo ele atendia todas as modalidades a partir principalmente do PIQ II final, inicial já articulado à formação profissional e ele teve que recuar, ofertando mais especificamente a área de estética e a área de informática e praticamente só no PIQ III que a gente dá um aprofundamento maior na formação profissional articulada a elevação de escolaridade. Isso por conta que se viabiliza dados as parcerias nossas, não com recurso próprio da prefeitura, porque a gente não tem recurso para esse tipo de ação. Então, tudo isso foi ficando muito difícil. O ano passado foi solicitado pelo DET uma proposição e um estudo do Observatório com base nos itinerários flexível e modular. Nós elaboramos essa proposta em janeiro de 2007, ela foi debatida e discutida ao longo do ano e ao que parece estaremos implementando em 2008 alguns experimentos, não vamos apresentar para todos os centros públicos, mas um ou outro nós vamos fazer projeto piloto. Com vistas a identificar por exemplo quais são as nossas reais dificuldades de financiamento e de funcionamento dessa proposta, então por exemplo, um trabalhador pode vir, faz um módulo ele recebe X créditos, poderão ser 10, 20 créditos, de acordo com a quantidade de horas que compõe esse módulo, ele fica parado dois, três meses, ou seis meses, vai fazer um trabalho em outra cidade, outro local, e depois ele retorna aos estudos, e vai somando esses créditos. Quando ele somar a quantidade necessária de créditos ele poderá receber o certificado integral. Ele vai recebendo então certificados parciais por módulos neste momento, e posteriormente ele recebe o certificado integral, apresentando toda quantidade de carga horária necessária, de acordo com o Programa Integrado de Qualificação. Esse é um estudo que o Observatório realizou, que está pronto, está na mão do Departamento já foi debatido e discutido, e agora pretende ser implementado. Existe uma outra proposta que o Observatório também realizou junto com a equipe do DET que refere-se ao aluno terminando o ensino médio, com base nas parcerias e nos convênios, nós poderíamos articular que ele fizesse mais um ano de ensino técnico, e ele teria um certificado como técnico, não mais apenas do ensino médio, isso ajudaria inclusive na sua entrada no mercado de trabalho, de forma mais efetiva, porque esse um ano técnico seria praticamente voltado aos conhecimentos específicos de uma ocupação profissional.

Sandra: Mas esse ano técnico seria ofertado pela Prefeitura ou seria em colaboração com as escolas técnicas?

DET3: Seria em colaboração com essas instituições que eu falei, as escolas técnicas, sistema $\mathrm{S}$, Senai etc. A idéia nossa é que seja essa a articulação. 
Sandra: Essa é uma conversa que vocês ainda vão fazer?

DET3: Já iniciamos essas conversas, já iniciamos. Principalmente com o Governo Federal. Com referencia às escolas técnicas federais. Como é um parceiro, digamos assim prioritário aqui da prefeitura, nós acreditamos que possa ser viabilizado. Não posso dizer prazo, porque na vida, é muito dinâmico, mas esse é um caminho que nós estamos trilhando ultimamente.

Sandra: Agora eu queria que você falasse o seguinte: todos esses estudos que o Observatório faz, ele vai para o Departamento, você não tem uma relação direta, por exemplo, com os Centros Públicos na hora em que eles vão fazer os planos de trabalho?

DET3: Em alguns momentos nós somos solicitados para estar presentes, em alguns debates, em algumas discussões, onde a gente procura levar uma referencia bibliográfica, procura levar algumas experiências que porventura exista em algum outro lugar do mundo, ou da cidade, ou da região ou do país. Então nesse contexto a gente participa. Fora disso, os documentos eles são direcionados para o Departamento de Educação do Trabalhador, cabe a ele inclusive, determinar se ele vai ser publicizado ou se ele não vai ser publicizado, se ele está a contento ou se ele não está a contento, então esse é o papel mais específico do Observatório. Participamos quando somos chamados.

Sandra: E vocês conseguem atender as demandas que os Centros Públicos pedem?

DET3: Nem sempre, uma vez que as demandas dos Centros Públicos são de grande monta. Por exemplo, tem uma pesquisa específica que dois Centros Públicos nos solicitaram. Uma é exatamente na área da estética, com vista aos cabeleireiros, essa tá pendente, que eles gostariam de saber por exemplo "poxa, nós estamos formando assistentes de cabeleireiros e cabeleireiros ao longo desses últimos cinco, seis anos. Afinal, onde estão essas pessoas e quantos empreendimentos eles formaram. E essa quantidade de empreendimentos, ela está saturada ou ainda tem espaço pra mais empreendimentos nessa área?”. Então essa é uma pesquisa que não é uma pesquisa simples, é uma demanda que um Centro Público fez, mas não chegou a oficializar, porque se oficializasse a gente teria que pelo menos iniciar o processo, mas chegaram a oficializar, mas já falaram, mas de uma forma não oficial, não formal. Outra demanda que a gente conseguiu atender foi, por exemplo, do estudo na implantação e por conta da inauguração do Centro Público João Amazonas, na época, onde nos foi solicitada a pesquisa, nós conseguimos fazer, então quer dizer, umas demandas a gente atende, outras a gente não atende, e isso vai muito da prioridade que se dá as demandas pelo próprio Departamento, que as demandas embora possam ser feitas diretamente, elas são remetidas como consulta ao Departamento que é responsável pela área. Então o Departamento diz "não, isso aqui nós não consideramos prioridade pra agora, vamos atender essas outras demandas aqui". Porque é como eu disse o Observatório, pelo seu escopo, e pela sua abrangência de ações esses cinco eixos têm tomado muito tempo, o monitoramento mesmo é um trabalho extremamente pesado, e é uma área de trabalho que o Observatório até faz questão de fazer, mas diretamente, como eu disse com os dados primários relativos ao DET, dado a integralidade das políticas públicas que o Observatório enxerga, quer dizer, o DET, ele tem uma conotação e ele tem uma abrangência diferente do outro departamento de educação fundamental e infantil que compõe a Secretaria da Educação, quer dizer, ele procura articular as novas tecnologias, ele procura articular o desenvolvimento econômico, a geração de trabalho e renda, mesmo essa questão do meio ambiente, a questão da reciclagem da madeira, essa questão da manutenção dos equipamentos públicos, dentro de uma política de um programa de formação profissional que é o PIQ, então quer dizer, essa heterogeneidade e essa 
diversidade que se apresenta no Departamento, ela consome do Observatório, pelo menos $60 \%$ do seu tempo, tanto na elaboração de projetos, como no monitoramento. Tanto é que o Departamento está procurando constituir de forma própria uma equipe que vá realizar esse monitoramento, e que vá elaborar projetos, diretamente para o Departamento, a partir de 2008.

Sandra: Voltando um pouco a questão do financiamento no terceiro eixo do PIQ que é o trabalho social. Você já falou brevemente sobre ele, mas eu queria que você aprofundasse. Por que ele não aconteceu?

DET3: Pois é, esse eu acho que é o grande desafio do PIQ, uma vez que temos três eixos estruturantes, porque também temos três eixos pedagógicos. Nós consideramos o terceiro eixo do PIQ um desafio nacional, porque o próprio governo federal quando apresenta o PROJOVEM como um programa que procura dar conta dessa experimentação do jovem, dessa elevação de escolaridade e a inserção dele no mercado de trabalho, ele também acaba se deparando com alguns desafios, que é exatamente o período da entrada desse jovem no mercado de trabalho. Embora a política liberal diga que não existe almoço grátis, só que quem não almoça também tem um custo. Então se você apresenta uma política que não dá conta de um feixe de necessidades do jovem ou do adulto, você acaba tendo que atender ele em outras áreas, outras secretarias. Por exemplo, área de saúde. Se você não trabalha a prevenção na área de saúde, lá na ponta você vai ter que dar conta e talvez o custo seja até maior. Então o jovem se não tiver na sua idade adequada na escola, você lá na frente vai ter um trabalho muito mais forte pra fazer, pra ele poder tentar pelo menos acompanhar aqueles que estão em um nível de escolaridade adequado. Isso vale para o mercado de trabalho. Quando você diz que pretende propiciar um estágio social para o jovem ou o adulto numa área, seja para aqueles que estavam desempregados e estão mudando de área, você precisa ter condições de oferecer um ambiente adequado, que não seja insalubre, não seja utilizado para substitui trabalhadores, e que ao mesmo tempo ele de fato aprenda e possa inclusive vir a ser indicado por essa própria empresa ou pela instituição para trabalhar em outro local. Quer dizer, você na verdade quando busca uma parceria de inclusão do terceiro eixo do PIQ, você também está buscando parceiros que vão ajudar a avalizar se esse trabalhador, se esse educando, que está passando por esse processo de aprendizagem, está apto para essa nova função, se ele vai corresponder a essas novas atividades, do ponto de vista dos valores, da visão geral que ele tenha de mundo, do ponto de vista da capacidade de pensar, elaborar e realizar. Quer dizer, ao você preparar nos outros eixos do PIQ essas três capacidades do cidadão, ao mesmo tempo está procurando meios palpáveis de inseri-lo no mercado de trabalho. Então o desafio do terceiro eixo, passa por aí. Quantas empresas poderão vir aderir ao PIQ? Eu passei por essa experiência como eu disse anteriormente no Programa Jovem Cidadão do governo do Estado, que também é um estágio para alunos do ensino médio, onde as empresas com base numa série de questões e elementos que a gente apresenta para eles, eles se apresentam e se cadastram nesse programa para oferecer horas de estágio, por quatro horas ou seis no máximo. A idéia é que o PIQ tivesse algo similar, que esse jovem ao mesmo tempo que ele estivesse estudando tivesse conhecimentos da área comum, do saber e da vida, ao mesmo tempo ele tivesse duas, quatro horas, ou seis horas durante o dia para fazer esse estágio, só que tem ser remunerado. E a remuneração que o Observatório propôs desde o início do PIQ é que seja no mínimo um salário mínimo, essa é a nossa referência. Porque se você dá cem reais como no PROJOVEM, muita gente não vai, tem outras atividades como em um bico que eles ganham isso, e ainda pode fazer um supletivo, não precisa ficar indo na escola todos os dias, quatro horas, todos os dias da semana. A escola além de não ser atrativa, para manter essas pessoas hoje, ela não dá conta dessas outras necessidades. De saber fazer alguma coisa e 
poder usar esse saber para poder sobreviver, se sustentar. Ao mesmo tempo ela poder ter condições de ter acesso ao lazer, a cultura, de poder usar seu espaço livre, para ela poder ser feliz, para ela buscar um novo status na sociedade e ao mesmo tempo das conta das suas necessidades de se vestir, de comer, de morar, de se transportar, e da própria saúde. Então quando você não consegue atender essas necessidades com uma política, essa política fica perneta. O PIQ, considero que ainda está no processo. O terceiro eixo nós já conseguimos aprovar na lei o terceiro eixo do PIQ, com uma série de regras para que as empresas participem, do ponto de vista da institucionalidade o PIQ contempla o terceiro eixo, agora do ponto de vista prático há necessidade de montar uma equipe específica para esse eixo como já se tentou, mas há uma necessidade de se estruturar essa equipe, onde as empresas possam ligar para cá e se inscrever, mediante documentos oficiais e dizendo qual é a oferta de trabalho que elas estão dando para essas pessoas. Algumas vão ofertar diretamente emprego, outras o processo de aprendizagem, onde as pessoas vão poder atuar. Tem que limitar a quantidade de pessoas por empresa, esse é o lado da iniciativa privada. De outro lado, nós achamos que a política de compras do governo federal, estadual e municipal, pode contribuir com isso. Talvez inserir com alguma coisa que ajude com que essas empresas, prestando serviço para o poder público, possam também utilizar esses educandos em um processo de aprendizagem de ocupação em determinada área. Esse seria dentro do terceiro eixo mais uma nuance, mais uma variável. Então o terceiro eixo pode trabalhar com a iniciativa privada, com regras claras para não substituir trabalhadores, e também não ser explorado e nem tampouco em área insalubres, pode atuar na área das organizações sociais civis, as OSCIP's, as ONG's, prestando serviços ou até mesmo em políticas públicas como a prevenção na saúde, agente de saúde, ou manutenção de equipamentos etc, todo esse leque foi elaborado e foi proposto por escrito ao DET, inclusive vinculadas às áreas da CBO. Nos balizamos nisso inclusive para apresentar, que áreas esses jovens ou esses adultos poderiam exercitar esse processo de aprendizagem prática a partir do terceiro eixo do PIQ.

Sandra: E não necessariamente essa aprendizagem estaria ligada ao seu curso de qualificação.

DET3: Não necessariamente, porque você, por exemplo, pode pegar algo similar. Você pega um setor, a área dele está vinculada a esse setor, porque nós consideramos hoje, dentro do Observatório, que os cursos que podem propiciar uma viabilidade da entrada do jovem ou adulto no trabalho, são aquelas que consigam transitar em um maior número de ocupações possíveis. Posso citar por exemplo um engenheiro que pode atuar em várias áreas, pode atuar na área que um economista atua, pode ser um professor, pode ser um ajudante, pode ser na área de logística, quer dizer, a profissão de engenheiro ela pode atuar em qualquer área praticamente, ele precisa obviamente se especializar em alguns momentos, para determinada área. Então nós pensamos que alguns cursos nas áreas técnicas eles teriam que ter essa capacidade de transitar por diversas áreas ou diversas ocupações profissionais, para que o trabalhador ou o jovem quando tiver sendo formado por esses cursos ele não fique preso numa armadilha de um determinado cenário que foi apresentado em determinado momento da vida dele.

Sandra: No início o PIQ preconizava a questão do trabalho social dentro da própria prefeitura, através de uma cesta de recursos em que diversas secretarias participariam e o aluno então prestaria serviço nessas secretarias. Isso não aconteceu por quê?

DET3: Nós chegamos a efetuar algumas experiências com 60 jovens. Nós fizemos um piloto, aliás bem sucedido, através de um convênio com a Fundação Santo André o DGTR viabilizou pesquisa na área do Sacadura Cabral e esses jovens articulados chegamos a efetuar esse piloto 
nessa área social por dentro da prefeitura com base nessa cesta de recursos. Esse recurso desse convênio a origem dele era a prefeitura, que viabilizou esse convêrnio, para a implementação inclusive de uma central de autônomos, com vistas a articular esse trabalho de economia popular e solidária na cidade. Então esses jovens ajudaram nessa pesquisa que ajudou a viabilizar e estruturar a central de autônomos na região de Sacadura Cabral. Esses jovens chegaram a receber duzentos reais de bolsa, uma parte via Primeiro Emprego com recursos do FAT e uma parte via esse convênio que foi realizado. Mas não conseguimos expandir essa experiência. Fizemos reuniões com as secretarias, gostaram do projeto, mas na hora de viabilizar o recurso foi o nosso gargalo.

Sandra: O PIQ nasce aqui mas traz idéias... ele pega fontes da onde?

DET3: A primeira fonte na verdade ela passa de uma análise ex ante efetuada já na época pelo próprio Observatório, inclusive eu não estava aqui quando foi feito essa análise, esse diagnóstico, onde eles identificam que se as políticas não estão articuladas elas não dão conta do mínimo necessário para esse jovem ou adulto ser atendido e inserido no mercado de trabalho. Inclusive o PIQ nasce dando preferência de atendimento ao jovem. Está lá no seu documento principal. Esse é o primeiro ponto, ele se baliza nesse diagnóstico. Segundo, ele também olha, obviamente, para as experiências de políticas públicas francesas, onde você percebe que lá já vem sendo feito e proposto políticas públicas integradas, que algumas deram certo, outras deram errado. Você ao olhar para algumas experiências no mundo, você percebe que o que é possível ser aplicado no nosso país e o que é possível ser aplicado numa área específica. A cidade de Santo André tem uma realidade diferenciada das demais cidades. É uma cidade que trata a política pública geralmente de forma mais coletiva. Embora você apresente os documentos, apresenta as idéias por escrito, ela geralmente é tratada por um coletivo. O PIQ foi nesse sentido, quer dizer, embora ela tenha sido apresentado por uma equipe técnica inicialmente, isso foi colocado à disposição das pessoas e elas discutiram a sua viabilidade. Inclusive à luz, da legislação do marco institucional existente no país, o que que é possível, o que não é possível de perspectiva de médio ou longo prazo desse Programa. Então basicamente os referenciais teóricos estão nessas três pontas. O diagnóstico, a análise, ex ante, à luz das políticas internacionais quais são as experiências existentes e o que deu certo e está dando errado e por que. E nesse trato mais coletivo. Então ele se assenta nessas três premissas pra ele poder dar continuidade em sendo implementado.

Sandra: as discussões internas sobre educação profissional existentes aqui no Brasil não alimentaram isso?

DET3: Olha, eu diria que teve um seminário que foi realizado em Recife, que inclusive gerou a "Carta de Recife" que apresentava alguns elementos de política de formação profissional, de certa forma esses elementos foram levados daqui de Santo André para esse evento embora outras regiões e outras secretarias tenham contribuído para isso também.

Sandra: Em 2002 foi realizado um seminário aqui.

DET3: Isso, esse seminário em Recife foi antes desse seminário aqui.

Sandra: Não, foi depois.

DET3: Depois, então não estou concatenando. De qualquer forma esse seminário também contribuiu, os elementos levantados, porque é isso, toda atividade coletiva acaba apresentando 
novos elementos, que ajudam a pautar essas políticas, a elaboração dessas novas políticas. Então como eu disse, toda essa atividade coletiva ajudou na formatação desse programa, não foi algo de algum iluminado, uma pessoa que apresentou a idéia completa. Pode ter apresentado alguns elementos principais, mas isso obviamente foi alterado e complementado e ajustado nesse coletivo.

Sandra: Agora, da minha parte pra encerrar.O PIQ como você disse, inicialmente ele foi pensado para o Jovem.

DET3: Preferencialmente.

Sandra: Preferencialmente, aliás, ele era de 18 a 26 anos, e aí de cara, logo no início do Programa a gente já viu que a maior procura não era de jovens. A maior parte dos alunos tinha acima de 25 anos, acima de 30 anos, e os Jovens, não eram uma parcela insignificante, mas não era a maior parcela do programa. Junto com isso o PIQ foi se readequando institucionalmente, do ponto de vista da legislação da educação, ele foi se formalizando, porque ele era um programa informal, e pelo menos o PIQ inicial e o final, que seria o ensino fundamental, ele ta autorizado, regulamentado pelo Conselho Municipal da Educação, enfim, e isso foi dando uma outra conformação pro PIQ, então nas principais diferenças que eu posso observar, não só como quem está pesquisando, mas como quem vivenciou o processo é que assim, o programa inicialmente era pensado pra 18 a 26, você não tem basicamente essa população que procura, são pessoas mais velhas, depois na sua autorização formal, ele se adequou a lei da EJA que abarca jovens de 14 anos a idade indeterminada, então hoje você tem, num Centro Público, por exemplo, jovens de 14 e 15 anos fazendo curso de qualificação profissional, que antes não era uma orientação do Departamento, aliás o Departamento tinha um programa especifico pra jovens com menos de 18 anos, que era o PEMTE $^{28}$, que depois acabou não acontecendo mais. E hoje você tem isso, você tem um programa que integra elevação de escolaridade e qualificação profissional, de 14 a 80 anos. Como que você vê isso?

DET3: Eu vejo dois públicos que nós identificamos. um foi identificado antes do PROJOVEM que foi iniciado aqui em Santo André, que é exatamente as pessoas que estão em situação de analfabetismo absoluto que tava na ordem de $4,5 \%$ chegando a 21000 , quase 22000 pessoas na cidade, analfabetos absolutos e aqueles que embora soubessem ler e escrever, não tinham completado a sua alfabetização, e que, pelos cálculos efetuados pelo observatório chegavam a 70000 na cidade, inclusive estão nos documentos do Observatório. Essas pessoas ao completarem a sua alfabetização, principalmente dentre esses dos 70000 , e alguns dos 22000 dos analfabetos absolutos, precisavam ser encaminhados pra um programa que desse conta já imediatamente também da sua qualificação profissional, e em geral essas pessoas são mais adultas, são mais velhas, então o Observatório apontou isso pro DET, e o DET achou que era correto, até pra inclusive atender demandas sociais na sociedade, que clamavam por essas necessidades, passou também a dar prioridade pra essas pessoas oriundas do MOVA e do EJA, educação de jovens e adultos, tanto das EMEIEFs quanto dos movimentos populares. Ao fazer isso, o perfil se altera, na composição desses alunos que vêm a compor o PIQ, então uma grande quantidade dessas pessoas entram no Programa Integrado de Qualificação principalmente a partir do ensino fundamental I e depois o II. Então aquilo que se apresentava como 49, 51 ou 51,49 por cento de jovens que participariam do PIQ inicialmente, isso se modifica, esse é o primeiro elemento que a gente constata. O segundo elemento, que existe, esses jovens, quer dizer, com estudos pra se implantação do

\footnotetext{
${ }^{28}$ Programa de Educação para o Mundo do Trabalho.
} 
PROJOVEM aqui na cidade, nós detectamos aproximadamente 11000 jovens que não completaram o ensino fundamental, que por diversos motivos, ou estão parados, ou estão fazendo cursinho específico de informática, etc.

Sandra: Jovens menores de?

DET3: São jovens, que variam sua idade, pode ser a partir dos 16 anos até os 24 anos, ou dos $18 \operatorname{aos} 24$, então varia essa faixa etária.

Sandra: é, porque segundo os dados da SEADE, baseados no IBGE a gente tem $48 \%$ da população com mais de 25 anos que não tem ensino fundamental.

DET3: Isso nacionalmente falando ou no estado?

Sandra: Não, no município, $48 \%$.

DET3: Não, não chegamos a tudo isso não.

Sandra: Dados de 2000.

DET3: 2000, então isso já deve ter se alterado, porque com base no censo, com base inclusive no censo 2000 nós fizemos uma tabulação especial, com base no censo, junto com o departamento de indicadores aqui da prefeitura e nós detectamos 20000 jovens na época.

Sandra: Então por isso que eu te perguntei qual era a faixa etária, porque esse dado do IBGE é acima de 25 anos.

DET3: Não, não, nosso é antes, 18 a 24, aí pode ser mesmo $40 \%$.

Sandra: $48 \%$.

DET3: $48 \%$, porque a sociedade infelizmente, não tem em sua maioria oito anos de escolaridade, pode ser real mesmo, então quer dizer, é uma idade inferior

Sandra: Por isso que eu estou te dizendo, que talvez isso justifique essa questão do PIQ ser procurado também por pessoas mais velhas, porque é uma grande... é metade da população.

DET3: Metade da população não tem ensino fundamental.

Sandra: Praticamente, não tem ensino fundamental.

DET3: Então esses 11000 que nós identificamos no PROJOVEM nós achamos que é um público potencial do PIQ, só que mesmo o PROJOVEM ofertando R \$100,00 de bolsa, essas pessoas não vem pro PROJOVEM, quer dizer, não é atrativo o suficiente, o PIQ também não é, se for olhar por esse aspecto, ou seja, quer dizer, o jovem tem uma avenida pela frente e ele tem que correr atrás de certos prejuízos, que ele acha que está no prejuízo, no jargão popular, ele só vai fazer um curso, ou só estudar ou até articular isso com alguma atividade ou algum trabalho, se esse curso for atraente do ponto de vista da remuneração também, ou seja, o tal do terceiro eixo do PIQ, se ele receber uma bolsa de $\mathrm{R} \$ 350,00, \mathrm{R} \$ 400,00$ ou $\mathrm{R} \$ 500,00$ talvez ele fique, ele estude realmente, fora isso não. Aí você fala "mas quer dizer que pra eu ajudar a 
população ainda tenho que pagar a população pra população vir estudar?". Sim, hoje nós consideramos que os elementos pra atrair as pessoas para elas estarem estudando, esse é um dos elementos principais, senão as pessoas vão optar pela sobrevivência. Independente das condições que ela esteja. Se a escola puder estar contemplada nessa luta pela sobrevivência, ele tiver compreensão disso, ele vai atrás. Então quer dizer isso também fez com que a faixa etária do programa se alterasse. De fato, a maioria da faixa etária dos educandos do PIQ hoje está acima dos 25 anos de idade, embora organismos como a ONU considerem que jovens, em determinadas condições, até 29 anos é jovem, embora tenha pessoas adultas, que já tem filhos, constituiu família, com menos de 20 anos hoje, embora não seja geral isso. Então quer dizer, nós consideramos que o PIQ, ele tem uma perspectiva que possa dar cabo e dar conta dessa situação toda, mas ele carece atuar nos elementos que são seus nós e um dos seus nós ainda é esse financiamento, e esse financiamento não é só para a implementação do programa em si, mas também, principalmente, para a implementação do terceiro eixo do PIQ.

Sandra: Quais seriam os outros nós do PIQ?

DET3: Olha, eu acho que um dos nós que a gente já identificou e vai tentar implantar um piloto agora em 2008 era essa questão dos itinerários formativos flexíveis e modular. Nós consideramos isso um grande nó, porque isso não atendia as condicionalidades do trabalhador. E daí eu não me refiro só a área da construção civil, tem diversas outras áreas de ocupações que também tangenciam essa situação. Esse é um dos nós. O outro nó eu acho que refere-se um pouco ao calendário escolar também, embora a gente não tenha discutido isso no coletivo.

Sandra: Por conta da formalização do PIQ

DET3: Exatamente, o calendário escolar, nós achamos que ele precisa de adaptações, ele precisa de adaptações, de alterações, ou seja, há de se ter mais horas de estudo, há que se ter, talvez dentro do próprio Centro, mais horas de conhecimento prático na determinada ocupação, então por exemplo, os laboratórios, por exemplo, você vai aprender a fazer móvel, você vai aprender a fazer móvel adaptado aos deficientes, você precisa ter um laboratório mais adequado, que ele possa, tal qual, a gente vai fazer aula de física, química ou biologia, a escola tem que ter o laboratório ali, pra você fazer os experimentos e testar as teorias, então você pode ter três horas por dia de conhecimento do núcleo comum, história, geográfica, matemática, língua-portuguesa, etc. então você teria que ter pelo menos mais duas, naquele dia de conhecimento pratico.

Sandra: Na formatação inicial do PIQ, três dias da semana eram para os conhecimentos da base comum, e dois dias [...].

DET3: Que se for distribuído, dá mais ou menos isso que eu estou falando.

Sandra: E aí, com a alteração do PIQ, se colocou um dia só. Na verdade já se tinha uma avaliação anterior por conta da suplência profissionalizante porque a profissionalização uma vez por semana é ineficiente. Ineficaz. E na verdade o PIQ retomou isso mesmo sabendo que isso não dá conta.

DET3: Então, isso é um dos nós que a gente identifica. E isso se deu por conta da adaptação da legislação e da formalização, então quer dizer, esse é o nó. É isso, o Observatório ele tem procurado, mostrar, olha, vocês mudaram, mas o caminho correto é aqui, vocês saíram do 
eixo, saíram do rumo, saíram do caminho. Então esse é o nó que nós identificamos exatamente com essa passagem, com essa alteração, com essa formalização do programa, então ela permanece, então é um nó que pode inclusive, digamos assim não dar conta das necessidades que os cursos que estão sendo proposto estão sendo dados pros trabalhadores. Daí a necessidade mesmo nessa formalização você talvez consiga fazer esse mais um ano técnico e a pessoa inclusive obter o certificado de técnico também.

\section{Sandra: No PIQ III?}

DET3: No PIQ III, mas aí você permaneceria com esse nó no ensino fundamental.

Sandra: Inclusive o PIQ III como não é um curso formal ele continua com essa característica, de três dias da semana base comum e dois dias as aulas...

DET3: Exato, que também nós achamos ainda insuficiente, quer dizer, vai pra um ano e meio ou faz mais esse um ano técnico, e ganha lá o certificado de ensino técnico em determinada área, então quer dizer, eu considero esses três nós do programa como os principais. Essa questão do terceiro eixo, a bolsa, financiamento, da bolsa, e ao mesmo tempo o financiamento de equipamentos, de laboratórios, de uma melhor estruturação do programa. Esse é um dos nós que é o do financiamento. $\mathrm{O}$ outro nó é essa questão do calendário, que eu te falei. $\mathrm{E}$ o outro nó é que eu acho que a gente pode começar a dar conta, que é essa questão do itinerário formativo flexível e modular. Basicamente eu considero esses três nós hoje dentro do PIQ. Essa questão da formação dos professores, dos instrutores, eu acho que tende a ir se ajustando, você vai identificando as necessidades de melhor preparação dos professores, dos educadores e dos instrutores pra dar conta do escopo do programa.

Sandra: Da minha parte era isso, eu agradeço, eu acho que você deu uma visão bastante concreta do programa, agora se você quiser fazer mais algum comentário, incluir mais alguma coisa que você acha que é importante, que não foi tratado.

DET3: Olha, eu acho que é importante comentar o seguinte: o envolvimento das pessoas, eu acho que é assim, não é tecendo [...] não é nada disso, eu acho que as pessoas aqui em Santo André eu digo que talvez isso seja um diferencial. A educação de jovens e adultos envolveuse nessa política de formação profissional e passou inclusive a ter uma visão mais geral, em que pese um ou outro educador não ter conseguido apreender ainda em tempo essa visão, mas eu percebo que há um envolvimento bem profundo das pessoas que trabalham com educação de jovens e adultos com o programa integrado de qualificação, as pessoas assumiram o programa pra elas, e eu considero em políticas públicas, esse elemento como um dos elementos principais. Não adianta você propor uma política que aparentemente ela não gruda, ela não cola, ela ta fora do cenário, ela ta fora do eixo da cidade, e ao contrario, no Programa Integrado de Qualificação, ela se apresenta como política que as pessoas assumiram como sendo sua. Mesmo aquelas que vieram depois, sendo eu um deles, cheguei aqui exatamente quando ia ser implementado o PIQ em 2003, quer dizer, vai se apropriando das dificuldades, vai procurando soluções pra atender e superar as dificuldades que o Programa se apresenta no cotidiano. Eu considero este um dos elementos fundamentais em implementação de políticas públicas, seja qual ela for, ou seja as pessoas se apropriarem, se envolverem, quererem mudar, propor, inclusive acredito eu que muitas idas e vindas às vezes fora de tom que ocorreram ao longo dessas alterações todas, algumas mais calorosas, outras menos calorosas, se deve a isso, às pessoas assumindo uma política que coloca sua opinião e a sua posição em relação à ela, então eu acho louvável a apreensão e o envolvimento por parte dos educadores, dos 
professores, dos instrutores mais na área especifica do mundo do trabalho e das diretoras, coordenação pedagógica, que se envolveram e politicamente o fato do prefeito, que ai também tem a questão política, o prefeito bancou essa política, a secretaria Cleuza Rodrigues Repulho, até o ano passado secretária, bancou essa política então isso faz uma diferença muito grande. Óbvio que tendo a frente aí pessoas especializadas, outras em processo de aprendizagem, mas que compuseram toda a equipe, inclusive o próprio DET, o diretor Antonio Viana Balbino, os técnicos do observatório, a coordenação pedagógica, os APs, todos deram sua contribuição. Hoje o PIQ podemos dizer que o dono é a população, inclusive cabe a população defender essa política, e aí eu acho que falta talvez aí mais um pecado que a gente acaba tendo, que a gente acaba fazendo, fazendo e fazendo, mas não mostra pra todo mundo, é a publicização do Programa, quer dizer, fazer com que a população saiba mais sobre o Programa, saiba mais da sua importância, do seu papel, e quais são as possibilidades do Programa, até pra ajudar nessa briga pra melhorar o PIQ

Sandra: Lembrei de mais uma coisa.

DET3: Pode perguntar

Sandra: Na avaliação do Programa, quem vocês escutam para fazer a avaliação?

DET3: Em um questionário nós aplicamos a pesquisa. Nós escutamos os professores, os alunos, inclusive nesta última avaliação nós escutamos principalmente os alunos...

Sandra: Mas de que maneira?

DET3: Via pesquisa. E às vezes o próprio diretor chama aqui no DET alguns professores para pegar suas impressões, chama alguns AP's, diretores de unidade, para ele também ter usa própria impressão e confrontar com as informações que o Observatório passa via pesquisa, via análise, via relatório. Inclusive temos um mecanismo chamado canal aberto que fica na escola à disposição dos alunos, dos professores, dos funcionários e da população que chega e se quiser dar uma opinião deposita numa urna. Temos já dois relatórios desse canal aberto que aponta inclusive a opinião dos alunos em relação ao Programa, quais são as dificuldades, quais são as falhas, tanto da infra-estrutura do Centro Público quanto de professores, se o professor está mais preparado ou não, se o Programa é bom, se ele gostaria de indicar par alguém da sociedade, então temos diversos mecanismos para ouvir nesse processo de avaliação.

Sandra: Certo, obrigada então pela atenção e pelo tempão que a gente ficou aqui. 